Instituto de Letras - IL

Departamento de Teoria Literária e Literaturas - TEL

Programa de Pós-Graduação em Literatura - Pós-Lit

\title{
GLAUCO MATTOSO, O ANTIKITSCH
}

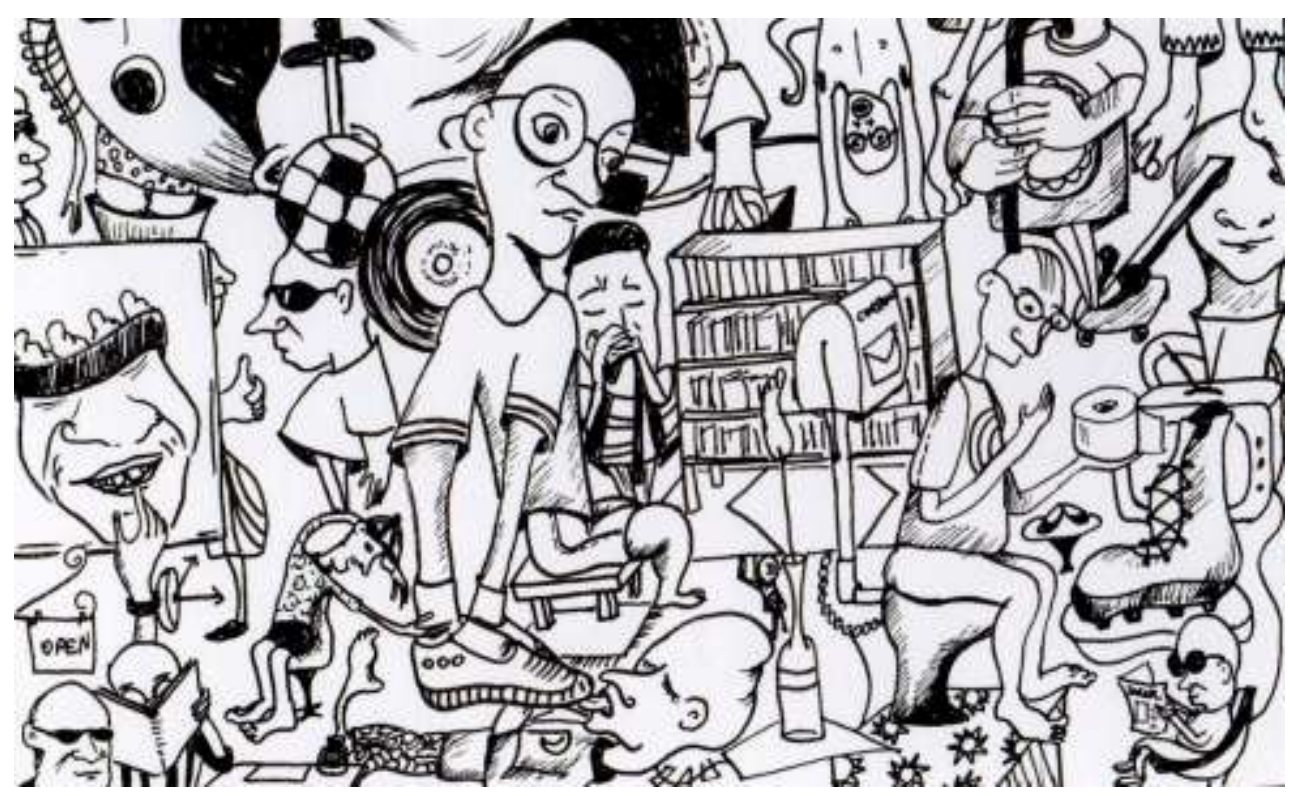

Ana Paula Aparecida Caixeta

Brasília, agosto de 2016 
Ana Paula Aparecida Caixeta

\section{GLAUCO MATTOSO, O ANTIKITSCH}

Tese apresentada ao Programa de Pós-Graduação em Literatura da Universidade de Brasília - UnB, como parte dos requisitos para obtenção do título de Doutora em Literatura, elaborada sob orientação do Professor Dr. Wilton Barroso Filho.

Brasília, agosto de 2016 
Ana Paula Aparecida Caixeta

GLAUCO MATTOSO, O ANTIKITSCH

BANCA EXAMINADORA

Dr. Wilton Barroso Filho (UnB - Presidente)

Dra. Susana Souto Silva (UFAL - Membro externo)

Dra. Florence Marie Dravet (UCB - Membro externo)

Dr. Anderson Luís Nunes da Mata (UnB - Membro interno)

Dr. Rogério da Silva Lima (UnB - Membro interno)

Dr. Piero Luís Zanetti Eyben (UnB - 1ํosuplente)

Dra. Sylvia Helena Cyntrão (UnB - 2o suplente) 
Ao Rafael e Rogério: por quem meu coração pulsa. 
Mais do que um simples gesto de menção, esses agradecimentos possuem uma sinceridade inefável. O processo de escrita da tese de doutorado, penso eu, é equivalente a um teste de amor aplicado aos que convivem com você. Há os que the acompanham durante todo o processo e aceitam seu mau humor, seu distanciamento e ostracismo, os assuntos intermináveis sobre sua pesquisa, os choros de desespero e a compra compulsiva de livros ou o devorar de uma pizza...

Foram quase quatro anos de muitas discussões em grupo, muitas empolgações sobre o tema, muitos planos... mas muitas frustrações com o tempo, com as dificuldades externas, com o conciliar do trabalho $X$ tese, com questões pessoais, familiares, etc.

Se alguém assumir a feitura de um trabalho assim como algo leve e confortante, pode-se dizer que esse alguém é um sujeito, no mínimo, maucaráter.

Mas, voltando aos agradecimentos e esquecendo as dificuldades, deixo aqui, aos meus grandes companheiros de vida e jornada, um título mais importante que o de doutora: o da lealdade.

Muito obrigada:

Simão e Sueli, meus queridos pais, que sempre me amaram, apoiaram e ajudaram incondicionalmente;

Rafael, meu filho maravilhoso, que pegava no meu pé para não procrastinar ("Mãe! Vai fazer a tese!") e aos 13 anos já não gosta da pósgraduação, que roubou boa parte do tempo em que estaríamos juntos;

Meus irmãos, João Paulo e Aline, por me ajudarem a levar tudo isso com muito humor ("Nós, da UnB");

Meu companheiro Rogério, que há 10 anos sabe o que é dividir-me com os livros;

Meus grandes amigos Fred, Gustavo e Eudes, por também compreenderem minhas angústias e estarem sempre presentes, especialmente 
o Fred, que amenizou meus piores momentos com sua amizade incondicional, munida de seu escárnio único;

Queridos companheiros, amigos do grupo Epistemologia do Romance: Vera, Mara, Herisson, Lindka, Itamar, Nathália, Denise, Aldair, Lucas, Dirceu, Manu, Etel... por aguentarem meus chiliques de desespero ("não vou conseguir!") e meus intermináveis comentários no meio da aula. Especialmente, agradeço a três grandes pessoas, que, com amizade, leituras e conversas pacientes, ajudaram-me nesse meu difícil trajeto de doutoramento: Mara, Vera e Herisson. Vocês são demais!

Também sou grata às amigas feitas no TEL, Juliana e Ana Catarina, pelo carinho e amizade para além da instituição;

Aos amigos feitos no meu antigo trabalho como professora da SEDUCE/GO - em especial, agradeço à Ludmila, pessoa querida, companheira de angústias da pós-graduação e confidente de longa data;

À minha psicóloga Halyne, por me manter lúcida nesses anos de doutoramento.

Não poderia faltar aqui o poeta pelo qual venho debruçando meu tempo de estudo: Glauco Mattoso. Obrigada pelos livros presenteados e pelos e-mails atenciosamente respondidos.

Para concluir, agradeço especialmente ao meu orientador Wilton Barroso, que, além de professor, tornou-se um grande amigo, ajudando-me academicamente a ser quem eu sou hoje.

Provavelmente fui negligente nesses agradecimentos. Se isso aconteceu, é importante ressaltar que a cabeça de um doutorando nunca é tão boa quanto parece. Por isso, concluo com um grande muito obrigada a todos que, de alguma forma, fizeram parte desse processo. 


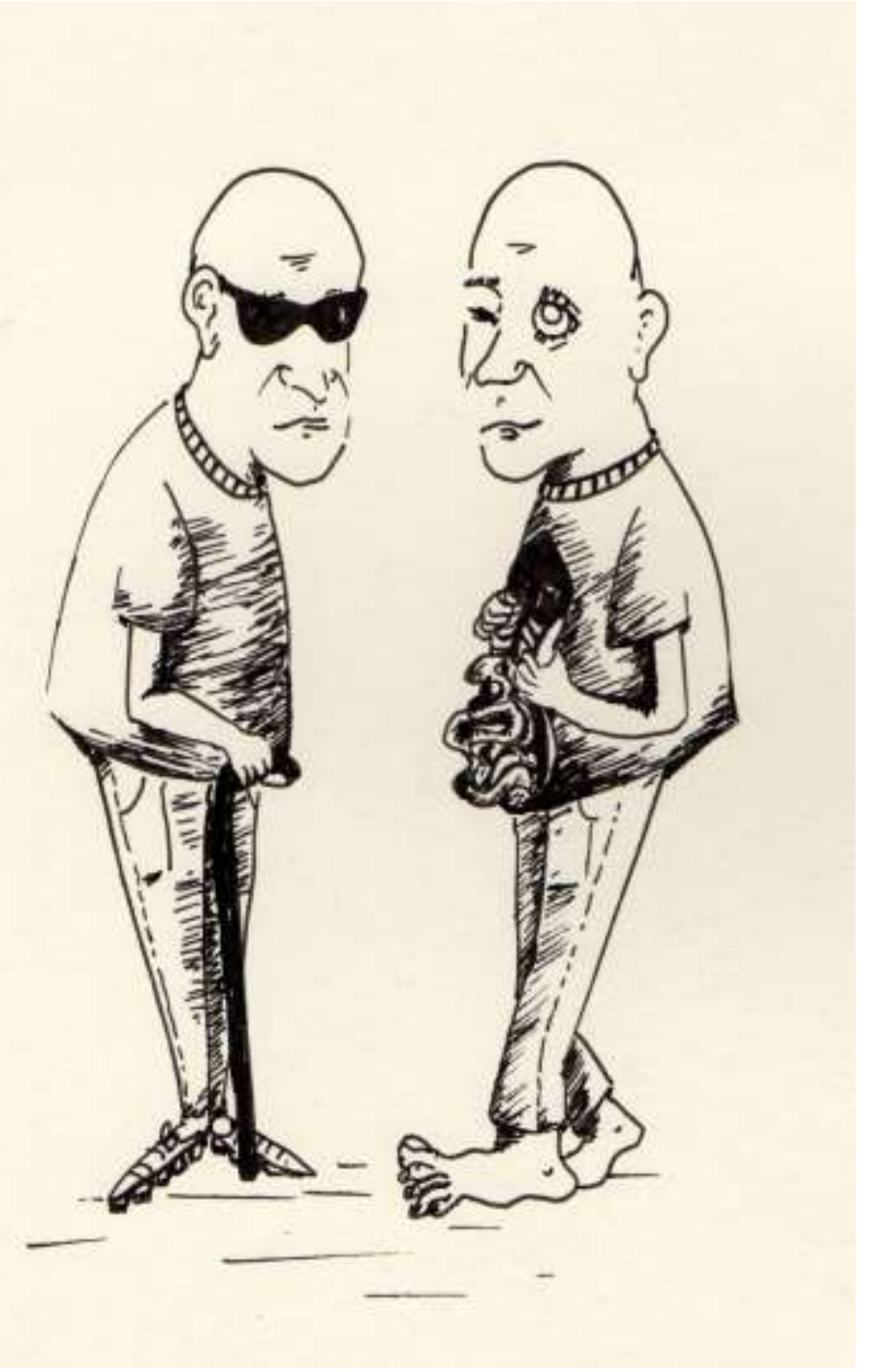

independen

te

men

te

de quem

te

men

te

tens o de

ver

de

outra ver

dade de

fender

Glauco Mattoso

Eu-Mattoso, Ana Paula Caixeta, 2015. Caneta nanquim sobre papel. 
Esta tese busca compreender a estética criada pelo escritor Glauco Mattoso (1951), destacando-o como instância literária, cuja escrita contestatória, fetichista e confessional compõe sua obra, da prosa paródica aos sonetos fesceninos. Entremeio a intertextos e diálogos de linguagens e formas, o escritor paulistano transita pela temática da tortura e do fetiche por pés, representados cruamente pela dor da sua condição de cego. Aqui, o recorte de discussões feito para se pensar a obra do autor é construído metodologicamente a partir do olhar da epistemologia do romance, buscando entender questões estéticas relacionadas ao contexto da criação enquanto razão sensível, que, em Mattoso, são conduzidas por um discurso autoficcional e heteronímico. Para justificar esse trajeto de análise, buscou-se nos estetas clássicos Immanuel Kant e F. Hegel - aqui julgados como fundamentais na compreensão do processo de criação -, elucidar questões acerca da escolha estética enquanto linha epistemológica, histórica, sensível e racional, que forma o conjunto da obra de Mattoso. A análise parte, especialmente, do principal texto em prosa do escritor, a narrativa autoficcional Manual do podólatra amador (1986/2006), para dar conta dos elementos contextuais que contemplam seu trajeto de publicações, construído a partir de escolhas estéticas que se repetem. Por se repetirem, foi necessário evocar outras obras de Mattoso, como o JORNAL DOBRABIL, com a intenção de alcançar a linha estética por ele conduzida. Pensar a estética em Glauco Mattoso implica pensar uma antiestética - definida nesta tese como contrariedade a um estilo kitsch -, chamada aqui de "antikitsch", em que a negação da harmonia e o desvelamento do "não-dito" ganham forma no espaço literário de Mattoso, por meio do seu mote maior: a merda. Da criação literária ao contexto de abjeção, vários autores foram fundamentais para se pensar o autor e suas características confessionais, como Michel Foucault, Wolfgang Iser, Serge Doubrovsky, Fernando Pessoa, Julia Kristeva e Michel Maffesoli. Os anseios deste trabalho almejaram por um olhar "multi", que alcançasse os elementos 
fundamentais sustentadores do eixo epistemológico desta tese, dividido em três partes: $O$ glaucomattoso, $O$ autoficcionista e $O$ antiestético.

Palavras-chave: Glauco Mattoso; estética; autoficcional; heteronímico; merda; antikitsch. 
The present thesis aims to understand the aesthetics created by Brazilian writer Glauco Mattoso (1951), featuring him as a literary instancy, in which the contesting, fetishist and confessional writing composes his work, from parodic prose to Fescennine verses. Among intertexts and dialogues between languages and forms, this writer from São Paulo moves through themes such as torture and feet fetish, rawly depicted by the pain of his blindness. In this work, the selection of the discussions to analyze the author's work is methodologically built upon the point of view of the epistemology of the novel, in order to understand aesthetic issues related to the creation context as a sensitive reason which, in Mattoso, are leaded by an autofictional and heteronymic speech. To justify this path of the analysis, the classical aesthetes Immanuel Kant and F. Hegel - here considered essential to understand the creation process - were invoked to elucidate the topics about the aesthetic choice as a epistemological, historical, sensitive and rational lines of research that compose the work of Mattoso. The analysis starts mainly from his most important prose, the autofiction narrative Manual do Podólatra Amador (Handbook of the Amateur Foot Fetishist - 1986/2006), to address the contextual elements which contemplate the path of his publications, built upon aesthetic choices that repeat themselves. Because of this repetition, it was necessary to evoke other work from Mattoso, such as JORNAL DOBRABIL, aiming to reach the aesthetic line conducted by the author. To think about aesthetics in Glauco Mattoso is to think about an anti-aesthetics, defined in this thesis as the contrary to the kitsch style, here called anti-kitsch, in which the denial of the harmony and the unveiling of the "not said" take shape in Mattoso's literary scope, through his major motto: shit. From literary creation to abjection context, many authors were essential to analyze Mattoso and his confessional features, such as Michel Foucault, Wolfgang Iser, Serge Doubrovsky, Fernando Pessoa, Julia Kristeva and Michel Maffesoli. The goals 
of this work are to get a "multi" view, able to reach the main elements which support the epistemological axis of the thesis, divided in three sections: The glaucomattoso, The autofictionist and The anti-aesthetic.

Keywords: Glauco Mattoso; aesthetic; autofiction; heteronymic; shit; antikitsch. 
Cette thèse vise à comprendre l'esthétique créée par l'écrivain Glauco Mattoso (1951), le mettant en évidence comme une instance littéraire dont l'écriture contestataire, fétichiste et confessionnel compose son œuvre, de la prose parodique aux sonnets obscènes. En mélangeant des intertextes et des dialogues de langages et forme, l'écrivain de São Paulo passe par la thématique de torture et du fétiche pour les pieds, représentés crûment par la douleur de sa condition d'aveugle. Ici, le découpage de discussions fait pour penser l'œuvre de l'auteur est construit, méthodologiquement, à partir du regard de l'épistémologie du roman, en cherchant à comprendre les questions esthétiques liées au contexte de la création en tant que raison sensible, que, dans Mattoso, elles sont conduites par un discours autoficcionnel et hétéronyme. Pour justifier ce trajet d'analyse, on a cherché dans les esthéticiens classiques Immanuel Kant et F. Hegel - ici jugés comme fondamentaux dans la compréhension du processus de création - élucider des questions à propos du choix esthétique en tant que ligne épistémologique, historique, sensible et rationnel, qui forme l'ensemble de l'œuvre de Mattoso. L'analyse part, surtout, du principal texte en prose de l'écrivain, la narrative autoficcionnel Manual do Podólatra Amador (1986/2006), pour rendre compte des éléments contextuels qui contemplent son trajet de publications, construit à partir de choix esthétiques qui se répètent. Car ils se répètent, il a fallu évoquer d'autres œuvres de Mattoso, comme le JOURNAUL DOBRABIL, avec l'intention d'atteindre la ligne esthétique conduite par lui. Penser l'esthétique dans Glauco Mattoso implique penser une antiesthétique, définie dans cette thèse comme contrariété à un style kitsch, ici appelé " antikitsch ", où la négation de l'harmonie et le développement du «non-dit » prend forme dans l'espace littéraire de Mattoso, à travers sa plus grande devise : la merde. De la création littéraire au contexte de l'abjection, plusieurs auteurs ont été fondamentaux pour penser l'auteur et ses caractéristiques confessionnelles, comme Michel Foucault, Wolfgang Iser, Serge Doubrovsky, Fernando Pessoa, 
Julia Kristeva et Michel Maffesoli. Les aspirations de ce travail désiraient pour un regard " multi », qui atteignait les éléments fondamentaux supporters de l'axe épistémologique de cette thèse, divisée en trois parties: Le glaucomattoso, L'autoficcionniste et L'antiesthétique.

Mots-clés: Glauco Mattoso; esthétique; autoficcionnel; hétéronyme; merde; antikitsch. 
Ilustrações:

Capa - "Anti". Ana Paula Caixeta, 2016.

Epígrafe - Eu-Mattoso. Ana Paula Caixeta, 2016. \| 06

Introdução - Efeito estético. Ana Paula Caixeta, 2013. || 18

Primeira parte - Leitura e Língua. Ana Paula Caixeta, 2016. || 51

Segunda parte - Friç̧ões. Ana Paula Caixeta, 2016. || 116

Terceira parte - O olho saturado. Ana Paula Caixeta, 2016. || 173

Figura1 - Corpobra, Antonio Manuel, 1970. || 53

Figura 2 - Situação (Instalação), Artur Barrio, 1970. || 54

Figura 3 - Capa de um exemplar do Pasquim, sem indicativo de data. || 57

Figura 4 - Grupo Dzi Croquettes, 1973-1976 || 62

Figura 5 - Arte postal, Paulo Bruscky. \| 63

Figura 6 - Bandeira de Hélio Oiticica, "Seja marginal, seja herór", 1968. || 64

Figura 7 - A fonte. Marcel Duchamp, 1917. || 64

Figura 8 - Capa do jornal Lampião da Esquina, sem indicativo de data. || 67

Figura 9 - Capa do jornal Lampião da Esquina, sem indicativo de data. || 67

Figura 10 - Antologia da Revista Chiclete com Banana, v. 3, 2007. \|69

Figura 11 - Capa do JORNAL DOBRABIL, edição fac-similar de 1981. || 70

Figura 12 - Capa do JORNAL DOBRABIL, edição fac-similar de 2001. || 70

Figura 13 - Página do DOBRABIL, Glauco Mattoso, 2001. || 72

Figura 14 - Manifesto da Vanguarda, JD, Glauco Mattoso, 2001. || 74

Figura 15 - Página do DOBRABIL, Glauco Mattoso, 2001. || 76

Figura 16 - Página do Jornal Dadarte, JD, Glauco Mattoso, 2001. || 76

Figura 17 - Jornal Dadarte, JD, Glauco Mattoso, 2001. || 78

Figura 18 - Galeria Alegria, JD, Glauco Mattoso, 2001. || 79

Figura 19 - Capa do livro Galería Alegría. Glauco Mattoso, 1986. || 79

Figura 20 - Página do JD, Glauco Mattoso, 2001. || 81

Figura 21 - Revista Dedo Mingo, suplemento do JD, GM, 1982. || 84

Figura 22 - Revista Dedo Mingo, suplemento do JD, GM, 1982. || 74

Figura 23 - Capa da HQ Glaucomix, Glauco Mattoso e Marcatti, 1990. || 85 
Figura 24 - Verso da HQ Glaucomix; GM e Marcatti (desenho de Marcatti), 1990. || 86

Figura 25 - Página da HQ Glaucomix. GM e MARCATTI, 1990. || 87

Figura 26 - Capa do livro O calvário dos carecas, de GM, 1985. || 90

Figura 27 - Capa dos livros O que é tortura, Glauco Mattoso, 1986. || 94

Figura 28 - Capa : O que é poesia marginal, de Glauco Mattoso, 1982. || 94

Figura 29 - Cada de Lourenço Mutarelli, CD Melopéia (2001), de GM. || 100

Figura 30 - Capa do disco Tropicalia, foto de Oliver Perroy, 1968. || 100

Figura 31 - Capa do livro Skinhead, de GM, 1995. || 100

Figura 32 - Capa do livro traduzido por GM, 1993. || 100

Figura 33 - Glauco Mattoso - foto de Rubinho Chaves. \| 111

Figura 34 - Capa e orelha do livro Manual do pedólatra amador, 1986. ||118

Figura 35 - Verso - primeira edição, Manual do pedólatra amador, 1986. || 119

Figura 36 - Capa - edição do Manual do podólatra amador, 2006. || 119

Figura 37 - Os três pares de sapato, de Van Gogh, 1886. || 122

Figura 38 - Alex, protagonista do filme Laranja mecânica, de Stanley Kubrik, lambendo a sola de um sapato, 1971. || 126

Figura 39 - Glauco Mattoso, numa representação fetichista. Foto de Rubinho Chaves, 1977. || 127

Figura 40 - Os dez mandamentos do torturador, de GM, publicado na revista Chiclete com Banana $\left(N^{\circ} 3,2007\right)$ || 189 


\section{GM \| Glauco Mattoso \\ JD || JORNAL DOBRABIL (2001)}

Manual || Manual do podólatra amador (1986/2006)

ER \|Epistemologia do Romance

vs. \|versus 
- Introdução || 18

- Construindo o olhar de leitora-pesquisadora || 32

\section{Primeira parte: O GLAUCOMATTOSO}

- Capítulo 1 - A palavra, a imagem e a marginalidade $\| 52$

1.10 Contexto histórico: ditadura militar e a arte marginal || 52

1.2 A imprensa oficial $X$ imprensa nanica \| 59

1.3 Glauco Mattoso e a escrita homossexual durante o regime militar || 65

1.4 Publicações anarcopoéticas \| 69

- Capítulo 2 - A prosa glaucomattosiana e a abertura política || 89

2.1 Transitando pelo calvário dos carecas $\| 89$

2.2 Publicando na Brasiliense \| 93

2.3 O pedólatra || 96

- Capítulo 3 - O soneto como dominação do espaço || 102

3.1 O espaço do cego: a memória visual || 106

3.2 Soneto vs. Imagem: a forma fixa do verso figurativo \| 111

\section{Segunda parte: O AUTOFICCIONISTA}

- Capítulo 4 - Manual do podólatra amador : uma construção do eu || 117

4.1 Narrativas de um glaucomattoso \| 118

4.2 "Pedo" e "podo": para além de uma questão léxica \| 123

- Capítulo 5 - Glauco Mattoso, personagem de si mesmo || 133

5.1 Premissas sobre autobiografia e autoficção || 134

5.2 O Manual do podólatra amador: um caso de autoficção || 139

5.3 Personificação da cegueira como processo identitário heteronímico || 149 
- Capítulo 6 - Significados que ultrapassam o texto literário || 163

6.1 O contexto da ficção \| 163

6.2 Criação, verossimilhança e credibilidade em Glauco Mattoso || 165

\section{Terceira parte: O ANTIESTÉTICO}

- Capítulo 7 - A escolha estética || 174

7.1 Entre a poética e a estética \| 174

- Capítulo 8 - O politicamente incorreto do desejo de Mattoso || 180

8.1 A conversão da dor em gozo $\| 180$

8.2 A tortura consentida \| 183

- Capítulo 9 - Coprofagia: Glauco Mattoso como um antikitsch || 191

9.1 Abjeção e coprofagia || 191

9.2 O kitsch como um mal ético e a merda em GM || 197

9.3. O Antikitsch diante uma estética contemporânea || 209

- Considerações finais (ou depoimento) || 215

- Galeria || 220

- Referências bibliográficas || 241 


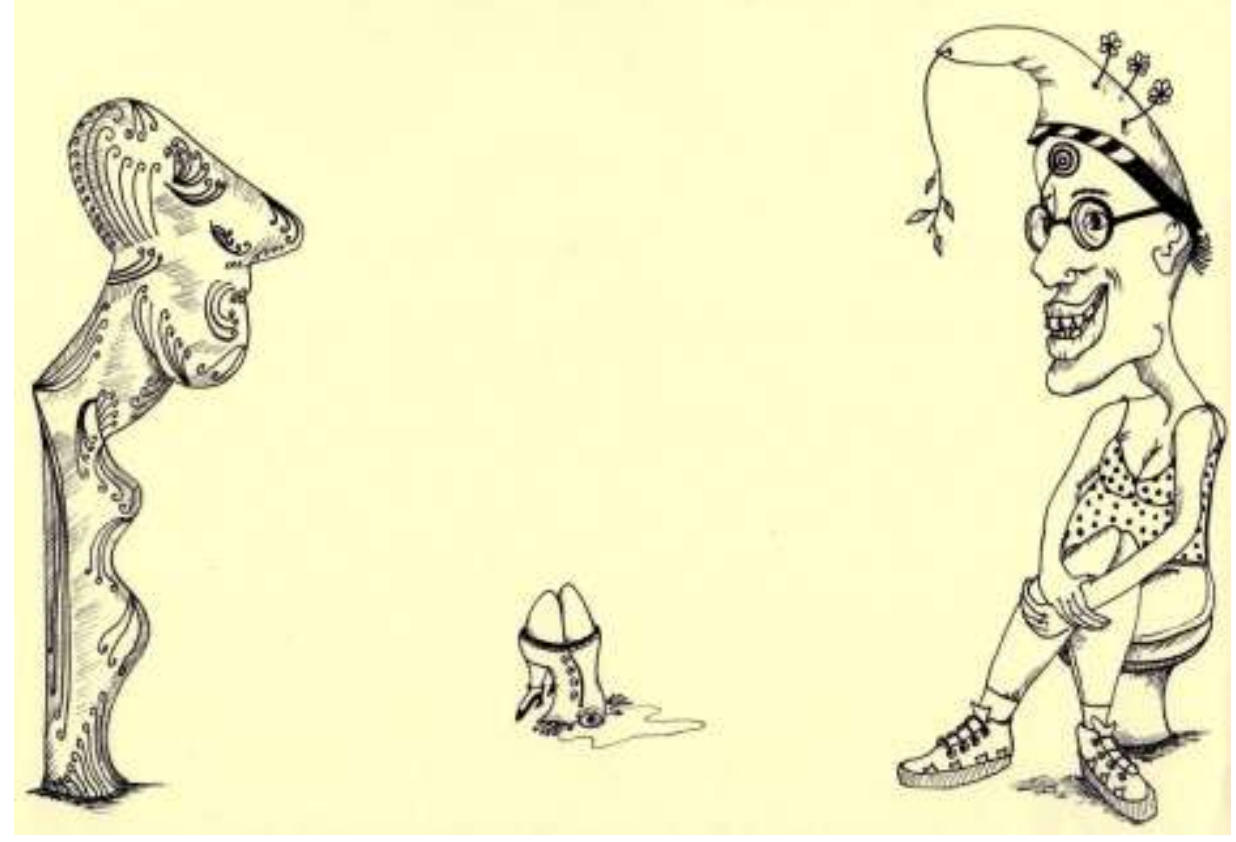

Efeito estético, Ana Paula Caixeta, 2013. Caneta sobre papel amarelo.

Numa busca por palavras alheias que ocupassem o lugar de epígrafe deste singelo introito, creio ter encontrado em Gadamer as mais pertinentes, por hora, para dar conta do processo que conduziu a feitura desta tese:

\section{A obra de arte ganha seu verdadeiro ser ao se tornar uma} experiência que transforma aquele que a experimenta. (p. 155, 2012)

Não consigo falar do meu objeto de pesquisa sem mencionar as angústias sofridas no decorrer do processo de doutoramento. Nunca escrever foi tão difícil. Limitar-se a uma linha, a um objeto, a um autor, a uma obra... Não é fácil manipular os diálogos teóricos acerca de tantas minúcias que partem da leitura do texto, por um processo, que a princípio, se propõe tão natural e sensível. Em se tratando de arte, as percepções acerca do objeto ecoam de todos os lados, renovando-se a cada leitura, permitindo novas perspectivas, num processo transformador infinito. 
Glauco Mattoso, um autor que produz compulsivamente no mesmo espaço de tempo em que se é pesquisado, desestabiliza seus estudiosos. Complica a linha de raciocínio tão cara para a pesquisa.

Não posso culpá-lo das minhas dificuldades em me ater ao estudo da sua obra, escolhida desde o início de meus esforços acadêmicos na pósgraduação. Mas também não posso negar as dificuldades enfrentadas quanto à compreensão da estética do autor, conduzida ao longo de seu trabalho literário. Fui fisgada pela sua arte. Minhas experiências se renovam a cada leitura e as percepções de leitora vão se fundido ao processo transcendente da relação sensível entre aquele que lê e a obra.

Nesta introdução, tentarei esboçar as etapas escolhidas por nós ${ }^{1}$ para pensarmos a criação estética do escritor Glauco Mattoso, começando com um esclarecimento da escolha do título:

\section{GLAUCO MATTOSO, O ANTIKITSCH}

Na primeira versão deste trabalho, o título, de extensão bem maior, calcava o adjetivo 'antiestética' para a literatura de Mattoso. Qualquer leitor seu, do mais despretensioso ao mais acadêmico, perceberá uma escrita, no mínimo, irreverente. Com uma linguagem de significações plurais, pode-se dizer, sem medo algum, que Glauco Mattoso constrói uma antiestética, que varia desde a exploração das visualidades poéticas ao processo autoficcional e heteronímico, até o mais incômodo e desarmônico tema ligado à "merda".

O termo "antiestética" ajuda a elucidar o conjunto de etapas da construção literária presentes na obra glaucomattosiana. Numa relação muito forte com o dadaísmo, se pensarmos a antiestética proposta por Rans Richter e Tristan Tzara, na época de publicação do manifesto Dadá em 1918, a relação do adjetivo, dialogado agora com a obra de Mattoso, parece bem pertinente. Há de se lembrar que o autor brasileiro, além de ser um dadaísta nato, como afirmou Décio Pignatari (apud MATTOSO, 1991), já vem carregando esse rótulo há um bom tempo, principalmente pelas discussões acadêmicas, ainda

\footnotetext{
${ }^{1}$ O pronome plural será aqui utilizado como forma de mostrar que este trabalho não nasceu de esforços solitários, mas de discussões em grupo, conversas e, certamente, das orientações do prof. Dr. Wilton Barroso Filho.
} 
que minguadas. O professor estadunidense Steven Butterman, pesquisador da teoria Queer ${ }^{2}$ na literatura e das manifestações LGBTT aqui no Brasil, já traz o termo antiestética na obra de Glauco Mattoso em seu doutorado defendido em 2003. Portanto, apesar da inconcretude do termo, ou talvez uma tendenciosa necessidade de enquadramento da obra de Mattoso, o adjetivo 'antiestética' se aproxima da ideia de contrariedade a qualquer manifestação estética, escola artística, estilo, normas, moda, academia... o que, também, contempla nossos anseios.

Obviamente, a opção por uma negação já indica uma profunda relação com o objeto negado. Portanto, Mattoso se apropria de estéticas para negá-las, colocando a oposição como forte elemento de criação.

Mas essa criação, para nós, passou a ser compreendida por uma linha, pensada pelos princípios de um estudo epistemológico do processo que conduz as escolhas estéticas. O contexto histórico da inserção do autor na literatura por meio da escrita jornalística e da poesia visual; a autoficção, característica no livro Manual do podólatra amador; e a heteronímia, construção identitária da figura do autor Glauco Mattoso, compõem o 'eu' que assume o caráter do prefixo "anti". Essa construção é reverberada por uma linguagem. Linguagem também de negação, que contraria a ideia daquilo que entendemos ser $k i t s c h^{3}$ : falseador, não da arte, mas da harmonia causada pelo seu efeito.

O "anti", como ação contrária à, pareceu-nos bastante pertinente ao se tratar do conceito de kitsch na obra de Mattoso. Aqui, procuramos incorporar essa aglutinação no sentido de (re)significar esse conceito, a partir da crueza da literatura do Glauco. O que entendemos como uma escrita antikitsch promovida pelo autor é a forma concreta de voz e força transgressora, formalizada à persona literária e moldada pelo processo autoficcional e heteronímico, que rompe com os estilos, não para falseá-los, mas para invertêlos: ética e esteticamente. Como um autor que tem a "merda" como seu maior

\footnotetext{
2 Teoria desenvolvida no final da década de 1980, cujos princípios se baseavam em desconstruir os rótulos pejorativos em torno das definições homossexuais. Uma das precursoras do pensamento é a teórica estadunidense Judith Butler. Informações disponíveis em: <http://www.cult.ufba.br/maisdefinicoes/TEORIAQUEER.pdf>

${ }^{3}$ Este conceito será melhor desdobrado no decorrer do trabalho, com espaço pontual na terceira parte da tese. Entretanto, adiantamos aqui o caráter dado ao conceito por nós abordado: o kitsch é a exigência e necessidade da harmonia, anulando o conflito ou desagrado diante da percepção sensível.
} 
mote de criação - ela, que é materialmente incômoda e significativamente desprovida de espaço -, a "merda", enquanto metáfora dos desvalores, sobrepõe todos os invólucros da criação enquanto ocupante de um território kitsch, pois ela corrompe e desestabiliza, por ser inaceitável. Dessa feita, Mattoso não é só um antiesteta, mais do que isso, é um antiktsch em seu significado mais metafísico possível.

Para um leitor familiarizado com a escrita glaucomattosiana, o título é também uma singela tentativa de homenagear os seus mais irônicos trocadilhos onomásticos. Por último, a escolha é um gesto cacofônico de anticristo, pois Glauco Mattoso está nas vias contrárias do permitido, do desejado e do evocado.

Dessa feita, apesar do título curto e direto, sua amplitude abarca aquilo que compreendemos da estética glaucomattosiana, vista, nesta tese, por três partes, que serão apresentadas adiante.

Após comentar a escolha do título, é importante esclarecer qual o tema que esse título abarca. Falarei dos aspectos gerais da pesquisa e como esse tema se tornou nosso objeto.

Esta tese nasce de outro trabalho. Minha dissertação de mestrado, na qual defendi, em 2013, aquilo que, irônica e pretensiosamente, chamamos de "estética do pé sujo". Nela, debruçamo-nos a pensar a presença da figura do pé e sua concretude na obra fetichista Manual do podólatra amador, trabalhando apenas com a reedição de 2006. Desse trabalho, inúmeras questões surgiram, sem, contudo, termos a oportunidade de maiores desdobramentos e aprofundamentos, haja vista o curto espaço de tempo para uma dissertação. Dentre essas lacunas, o que aqui optamos por chamar de autoficção e heteronímia, se tornaram latentes. Estes dois conceitos, embora observados na obra de Mattoso de modo peculiar, permitiram-nos pensar questões estéticas da criação literária que vão além dos modelos da teoria. Perseguiam-nos. Ambos caminham juntos no que compreendemos como a composição da narrativa aqui estudada. Assim sendo, desde o início do doutorado, percebemos a necessidade da abordagem de questões acerca do nome Glauco Mattoso, bem como da sua figura ficcionalmente trabalhada e insistentemente presente em sua produção, da prosa aos sonetos. 
Se o autor insiste em questões que se repetem, consequentemente isso começa a tecer uma estética própria, caracterizada por elementos presentes em vários textos por este publicado. Poderíamos elencar uma série de recursos estéticos repetidos na maioria dos seus textos: a figura do pé; a cegueira e humilhação do cego; as alterações e desdobramentos do "eu" pela exploração recorrente de verdade e ficção por meio de recursos autobiográficos; a tortura; o gosto paradoxal pelo desprazer em prol do prazer; o sadomasoquismo; o underground e o movimento punk; entre tantos, são bons exemplos na repetição da escrita de Mattoso. E para se pensar quaisquer desses elementos, entendemos ser necessário nos reportarmos à figura do autor.

Quem é Glauco Mattoso? Na verdade, seu nome de batismo, ou aquilo que Fernando Pessoa vai chamar de ortônimo ${ }^{4}$, é Pedro José Ferreira da Silva. É um paulistano nascido em 1951. Formado em biblioteconomia, também cursou parte da faculdade de Letras e afirma que não concluiu o curso porque não queria ser um acadêmico, queria escrever. Foi funcionário do Banco do Brasil, na cidade de São Paulo e do Rio de Janeiro, atuando na biblioteca em ambas. É cego. Escolheu o nome Glauco Mattoso como um trocadilho autoescarnecedor da própria condição de portador de glaucoma congênito doença que o levou à cegueira definitiva na década de 1990. Assume-se homossexual, fetichista por pés masculinos e sadomasoquista. Insiste em ser chamado de poeta maldito. É transgressor por rótulo e batismo, por literatura e representação. Escreve de acordo com a ortografia anterior à reforma de 1945. É o maior escritor de sonetos em Língua Portuguesa, segundo ele próprio e o Guiness Book - embora o poeta tenha se justificado, recentemente, em sua coluna Ephemerdas ${ }^{5}$, que há um concorrente em quantidade: Jorge Tannuri ${ }^{6}$. É diabético e gosta de cão basset. Inclusive, assume ter um de estimação, o Chicho, com direito a perfil no Facebook e textos em sua homenagem na coluna já citada - tudo indica que o cão é mais uma construção ficcional em torno da figura pública Glauco Mattoso. Tem como companheiro, Akira

\footnotetext{
${ }_{5}^{4}$ Nome de batismo (PESSOA, 2014).

http://www.blocosonline.com.br/literatura/prosa/colunistas/glauco/gm14emdiante/gmephem_15 08a.php

${ }^{6}$ Poenta, engenheiro de profissão, em 2008 já ultrapassa o número de 4400 sonetos publicados em livros registrados na Biblioteca Nacional. Informações disponíveis em: < http://www.poetasdelmundo.com/detalle-poetas.php?id=3861>
} 
Nishimura, um nipônico ${ }^{7}$. Amaldiçoa a cegueira. É pessimista. Tem uma vasta obra, cujos títulos ultrapassam mais de 50 publicações impressas e virtuais. Sua descendência literária vai desde os mais fesceninos poetas e escritores malditos, como Marquês de Sade e Bocage, aos cordelistas nordestinos, como - Cego Aderaldo. Utiliza-se da forma clássica para reverberar escritos de banheiro, fomentando seu conceito de coprofagia ${ }^{8}$.

Gosta de ultrapassar. Quer opor-se. A transgressão vai desde suas paródias de considerados autores e clássicos ao xingamento mais chulo da literatura, da política e do sistema. Fala de sexo "sujo" e sexualidade. Possui um conhecimento mnemônico digno de cátedra. É lexicógrafo e mantém um blog $^{9}$. Escreve compulsivamente. Seus textos tem a figura do "eu" como representação insistente de questões da condição humana, adotadas por ele como legítimas e necessárias de espaço para discussão. Dessa feita, a tortura, o trote e o bullying, todos ocupantes de um mesmo terreno de humilhação e sofrimento, são trazidos em seus textos das mais diversas formas, cuja ironia se sustenta por um discurso oportunista e politicamente incorreto, propondo-se em favor de tais práticas, contudo, fomentando-as para conscientização de uma sociedade que se mostra cada vez mais cruel. O prazer através da dor, defendido por Mattoso, nada mais é que a forma mais escancarada de incomodar o leitor quanto às questões do não-dito, que representam um desumanismo sórdido, velado, ignorado, daqueles que agem em prol do próprio prazer, destituindo as vontades e o prazer do outro. Acima de tudo, Mattoso é um denunciador, que não tem medo das palavras nem do peso que elas trazem consigo.

Mas por que nos são tão caras essas questões que ultrapassam os limites do texto escrito e vão ao encontro da figura do autor? Seria uma armadilha na qual caímos e nos deixamos levar pelas questões biográficas do sujeito que escreve? Mas o que esse sujeito escreve que nos reporta instantaneamente à sua figura, ao seu eu, as suas escolhas particulares? As

\footnotetext{
${ }^{7}$ Informação trazida aqui por ser intrigante e dialogar com questões presentes na narrativa Manual do podólatra amador (2006), em que Mattoso fala da sua predileção por nipônicos, devido aos "olhos puxados".

${ }^{8}$ Coprofagia é a ingestão de fezes. Em Glauco Mattoso, esse conceito será ressignificado como a "releitura escatológica da antropofagia" (MATTOSO, 2001), comentado com mais afinco ao longo do texto.

${ }_{9}^{9} \mathrm{http}: / /$ correctororthographico.blogspot.com.br/
} 
respostas estão nos próprios textos do autor. Tivemos acesso e leitura de parte considerável de sua obra publicada - certos de que existem publicações de textos esgotados nas editoras e não disponíveis na rede. O que Mattoso escreve gira em torno desse "eu" externo à obra. Que "eu" é esse? É Glauco Mattoso, mas não é Pedro José. Daí nossa defesa de que o nome Glauco Mattoso é, também, uma construção literária para dar conta da sua própria literatura, que é transgressora por natureza, logo, opõe-se à ideia de harmonia na arte, de Belo, de clássico, de romântico, de pureza, pois não é permissiva.

Nosso tema surgiu desse emaranhando de escrituras, cujas palavras são intencionalmente colocadas em favor do sujeito que escreve, como aquele que assume com prazer todos os aspectos da transgressão, negados em todos os contextos, inclusive pela própria literatura.

Qual seria então o problema maior que conduz a escrita dessa tese? Apesar da dificuldade de se criar uma pergunta precisa acerca de algo ainda subjetivo em nosso empreendimento de pesquisa, a questão maior que nos reporta ao nosso objeto é:

\section{Glauco Mattoso como um antikitsch é uma possibilidade de} (re)criar a si mesmo a partir da literatura, como denúncia da negação do humano existente dentro e fora do espaço literário?

Para nós, Mattoso se coloca, articuladamente, como cobaia. Ele se entrega em seus próprios textos a fim de desestruturar discursos sólidos, detidos por sistemas maiores, cujas discussões se mantêm ou negadas ou controladas, como no caso do sexo e da sexualidade, do fetichismo e da tortura. Colocar-se a si mesmo como ser que confessa taras e ações transgressoras acerca do que fere princípios de moral e ética é manifestar-se concretamente contra todos esses discursos, pois assume para si mesmo a responsabilidade. Mas só a assume porque está no espaço da criação, no espaço da arte e da ficção.

Por esta razão, para solidificar as possíveis respostas acerca dessa pergunta maior, decidimos construir um olhar que transitasse por algumas teorias estéticas e literárias, guiados pelo processo investigativo da 
epistemologia do romance ${ }^{10}$, em que o objeto estudado é minuciosamente "garimpado", numa permissão de possibilidades de verdades (repetições contextuais) dentro da obra. É a proposta de análise epistemológica uma forma de conduzir a pesquisa literária pelas perspectivas, não só da teoria da literatura, mas em diálogo com discussões filosóficas de teor estético, histórico e hermenêutico.

Tendo, portanto, o processo epistemológico sensível como guia de leitura, nosso olhar investigativo ansiou por compreender os princípios do pensamento estético e como se fundamenta a criação na arte. Para tanto, fezse necessário passar por filósofos idealistas, como Immanuel Kant e G. W. F. Hegel, para tentar dar conta da amplitude das etapas da criação artística, principalmente na sua relação entre razão vs. sensibilidade. Cientes de que os clássicos, isoladamente, poderiam não contemplar maiores possibilidades de leitura do nosso objeto, ao falarmos da antiestética glaucomattosiana, fomos ao encontro de um autor que pudesse pensar o contemporâneo enquanto individuação. Desse modo, Michel Maffesoli nos pareceu pertinente, ao abordar questões da razão sensível.

Kant nos faz necessário, principalmente, para se pensar sobre a fruição, o efeito estético e o gosto, o que permite o contato com o sublime pela relação entre sujeito e obra de arte. Mais do que isso, é pelo diálogo de suas críticas, que compreendemos o processo de conhecimento sensível a partir da arte, especificidade importante para nosso caminho metodológico. Quanto ao Hegel, nossas principais justificativas se encontram sobre seu olhar acerca de escolhas estéticas como provenientes de uma Ideia, nascida e conscientizada pela relação dialética entre a sensação e a razão do sujeito que cria, que é histórico e contextual. Ou seja, Hegel, neste trabalho, não sustenta nossa análise acerca do objeto, mas em nossa compreensão de como esse objeto foi pensado, organizado e esteticamente construído. Por isso, trazemos o conceito de Gestalt, numa relação entre forma e conteúdo, para, em diálogo com Gérard Genette, compreendermos como questões externas à obra contribuem para entender a mesma, pois fazem parte, numa provisória totalidade, de seu processo interpretativo. Quanto ao sociólogo Michel Maffesoli, o que nos

\footnotetext{
${ }^{10}$ Discussão fundamental que promoveu a feitura desse trabalho, oriunda do grupo homônimo, do qual faço parte desde 2010. Essa proposta de análise será comentada mais adiante.
} 
permite dialogar com a estética de Mattoso são suas discussões relativas às questões fenomênicas e imaginárias do indivíduo contemporâneo, que vão além da relação sujeito vs. objeto.

Falamos de autoficção partindo do conceito cunhado por Serge Doubrovsky, em seu livro Fils: obra romanesca em que o próprio Doubrovsky é trazido como autor, narrador e personagem, mantendo a homonímia, entretanto, rompendo o pacto explicado por Philipe Lejeune, acerca da escrita autobiográfica - já que, logo no início, Doubrovsky assume escrever um texto autoficcional. Essa discussão promove o questionamento acerca do nome do autor e como a presença do nome daquele que escreve legitima certos discursos literários como "verdadeiros" ou "legítimos".

Para ampliarmos nossos horizontes acerca do conceito de autoficção, trouxemos Vincent Colonna como possibilidade de se pensar o Manual do podólatra amador como uma autoficção biográfica, em que o sujeito, pelo processo de mitomania literária, ficcionaliza a si mesmo.

Também falamos de heteronímia, outro conceito importante nesta tese, cujo significado vai além do neologismo criado por Fernando Pessoa. Embora ultrapassemos as definições do poeta português, haja vista a particularidade do termo às suas próprias criações, heteronímia serve como base teórica para pensarmos o processo de escolha do nome do sujeito que escreve e como esse nome é representado literariamente. Acreditamos que a heteronímia em Glauco Mattoso é resultado da personificação da cegueira, de maneira a trazêla para o espaço concreto da vida de Pedro José. Ela deixa de ser apenas um mal que o assolou e passa a ser a voz presencial que escreve e assume todas as angústias por ele traduzidas literariamente.

Já o conceito de kitsch, termo comumente compreendido na arte como falso, brega ou de mau gosto, abarca o que Hermann Broch vai chamar de falsa harmonia. Para Milan Kundera, escritor que, para nós, melhor defende o conceito de kitsch adotado neste trabalho, o termo está ligado à "ocultação da merda". Ou seja, a ocultação daquilo que existe de mais rasteiro e sujo, ligados ao comportamento, às escolhas, prazeres e instinto humano. Exatamente por isso, pensam Broch e Kundera, torna-se necessário à humanidade e à arte a existência do kitsch, de modo a falsear todas as questões das quais os discursos não dão conta e negam. Isso vai além do objeto falso ou brega, 
enquanto gosto; está nas entranhas do ser humano, que contraria a si mesmo em prol da harmonia e do falso prazer, seu e do outro.

Seguindo esse raciocínio, Glauco Mattoso só poderia ser um antikitsch, pois faz da sua obra um espaço fecundo para uma exposição dilacerada das questões mais difíceis de serem traduzidas por discursos e, por isso, eufemizadas ou excluídas.

Dentre os teóricos citados, alguns outros são trazidos no decorrer da tese, de forma a colaborar com nossas intenções acerca da problemática maior aqui trazida. Falamos de discursos e autoria, com Michel Foucault e da relação difícil entre realidade e ficção, com Hans Vaihinger e Slavo Žizek; Também lidamos com o conceito de abjeção, pelas leituras de Julia Kristeva, como possibilidade de fundamentação das discussões acerca do tema proposto, embora nossas perspectivas não alcancem tensões psicanalíticas. Sendo assim, a tese ficou dividida em nove capítulos, distribuídos em três partes:

\section{- O GLAUCOMATTOSO \\ - O AUTOFICCIONISTA \\ - O ANTIESTÉTICO}

A primeira parte, O GLAUCOMATTOSO, tem por intenção falar do contexto histórico da escrita do autor, desde suas primeiras publicações à escolha da escrita em forma fixa, através do soneto. No Capítulo 1, chamado de A palavra, a imagem e a marginalidade, trabalhamos com o contexto da escrita do autor, proveniente do período de ditadura militar, bem como as manifestações acerca da arte marginal, circulada na época de censura. Também abordamos o processo de escrita do JORNAL DOBRABIL, folhetim importante para compreensão da escrita glaucomattosiana, tal qual a relação do escritor com a escrita jornalística da época de circulação do jornal: entre 1977 a 1981. Outro aspecto importante abordado no primeiro capítulo foi a discussão sobre a escrita homossexual durante o regime militar e outras publicações anarcopoéticas de Mattoso: dentre elas estão a Revista Dedo Mingo e a HQ Glaucomix.

No segundo capítulo, de título A prosa glaucomattosiana e a abertura política, transitamos pela escrita em prosa do autor - fase posterior à explosão 
concretista que compôs o DOBRABIL e a Revista Dedo Mingo -, como forma de compreensão da inserção do escritor no espaço literário e as alterações estéticas na sua escrita. Especificamente, é neste capítulo que falamos do Mattoso podólatra; o escritor que lambe pés e tem essa característica como fomentadora do 'eu' autor e de toda sua estética, numa forte metáfora das suas escolhas literárias.

No terceiro capítulo, $O$ soneto como dominação do espaço, nossa tentativa foi a de apresentar a escrita do soneto como escolha de dominação do espaço do cego, em que a memória visual ganha representação vívida e nítida nas palavras limitadas por 14 versos.

Contemplando a segunda parte, O AUTOFICCIONISTA, também composta de três capítulos, a abordagem principal está na análise das duas edições do texto corpus desta tese: a de 1986 e a de 2006. O capítulo quatro, que introduz a segunda parte, tem como título Manual do podólatra amador: uma construção do eu. Nesta etapa do trabalho, é feita uma exposição do que compõe essa narrativa, bem como das diferenças entre as duas edições, tidas, para nós, como determinante na questão da autoficção em Glauco Mattoso.

A narrativa, pluralmente classificada por diversos comentadores do autor, é chamada, principalmente, de autobiografia, mas também de romance, romance fetichista ou livro de memórias. Muitos adjetivos e poucas definições ainda bem. Não temos informações de que o livro tenha algum estudo empenhando em mestrado e doutorado, até o momento, além do nosso. Isso não facilita muita coisa, já que nossas defesas ainda são processuais. Entretanto, em se tratando de gênero discursivo acerca da escrita do Manual, podemos incitar uma coisa: o livro é uma mistura de gêneros com a presença do 'eu' autor, o que o coloca como uma autobiografia contemporânea, fragmentada e plural, tal qual o momento do qual faz parte.

Texto narrado em primeira pessoa, o protagonista da história é Glauco: menino nascido com glaucoma, muito estudioso, tímido e sofredor de bullying na escola. O garoto cresce, mas não aparece. Assume um ostracismo direcionado à leitura compulsiva. Sabia da possibilidade da cegueira e por isso lia. Lia muito. Começa a escrever e publicar. Colabora com jornais e revistas 
marginais. Cria seu próprio jornal. Escreve sua "autobiografia". Encerra o livro com reflexões acerca da cegueira e da memória.

No meio dessa jornada, as aventuras de Glauco fazem parte de discussões pouco comentadas no âmbito público: desde a masturbação infantil; violência sexual na infância, adolescência e fase adulta; fetichismos e sexualidades; tortura e exílio. Também fala de ditaduras e música; literatura e escrita; e, claro, podolatria. No livro, Glauco é um tarado por pés masculinos sujos, chulepentos, com frieira e micose. É escatológico e assume para si o gosto escancarado pelas secreções do corpo, tão negadas em todos os contextos possíveis.

A obra é de uma ironia nada sutil acerca da escrita memorialística e da manipulação de textos em primeira pessoa. É intertextual do início ao fim. O título, sugestivo de algo didático, distorce a primeira ideia que se tem, de um "passo a passo" acerca do assunto. É reescrito 20 anos depois, com muitas alterações que transgridem a ideia de uma autobiografia e da veracidade exigida pelo leitor de textos desse teor. E é exatamente por essa reescrita que defendemos a ideia de um texto autoficcional, cujo recurso estético maior está em ficcionalizar a si mesmo como forma de representação de questões da abjeção, que estão no âmbito da negação e do privado.

No capítulo 5, Glauco Mattoso personagem de si mesmo, trazemos a discussão teórica acerca da autoficção e heteronímia, buscando responder a pergunta: Pedro é Glauco?

Já no capítulo 6, Significados que ultrapassam o texto literário, o que é levantado ainda paira por um espaço problemático, em que a verdade e ficção são colocadas em polos. Aqui, nossos esforços estão em compreendêlos num mesmo espaço, o espaço em que a criação, a verossimilhança e credibilidade caminham paralelamente pela escrita literária.

Quanto à terceira e última parte, O ANTIESTÉTICO, nosso propósito maior foi o de dialogar as discussões anteriores ao estético enquanto elemento de linguagem, conduzido por escolhas do autor, para se alcançar o resultado da feitura do livro Manual do podólatra amador. Começamos com o capítulo 7 , de título Por uma escolha estética, com uma discussão acerca da relação entre estética e poética, para, posteriormente, falarmos, no capítulo 8 , d' 0 politicamente incorreto do desejo de Mattoso, em que a conversão da dor 
em gozo é alcançada pela linguagem sexual, o que promove um discurso livre acerca da tortura consentida.

No último capítulo da tese, Coprofagia: Glauco Mattoso como um antikitsch, apontamos o conceito de coprofagia, criado por Mattoso em seu JORNAL DOBRABIL e reverberado por toda sua linguagem poética, como recurso inventivo para se posicionar como um antikitsch. A coprofagia é definida pelo autor como a releitura escatológica da antropofagia oswaldiana. Entretanto, entendemos que sua intenção máxima está na apropriação da literatura alheia para transgressão, deturpação e ocupação daquilo que é negligenciado nos contextos múltiplos de arte, da história, do discurso. Mattoso assume-se como um recolhedor de restos. Ele se propõe, não só um revisitador de clássicos e populares e um jogador de intertextos, mas um defensor e promulgador da merda, em seu sentido mais cru possível. Desmoraliza a palavra, ferramenta sagrada para a Literatura (com L maiúsculo) e faz com que se execute um discurso fiel somente às suas necessidades e vontades, descontruindo o invólucro que circula entre as estéticas e poéticas da linguagem.

Presos à libertinagem e transgressão da escrita de Glauco Mattoso, assumimos a incompletude deste trabalho, que, obviamente, não acabará com o encerramento desta tese. Mattoso transborda uma sinceridade ofensiva e avassaladora, calcada num ressentimento alheio às prudências e convenções. Sendo assim, sem destituir a força deste trabalho nem ao empenho do leitor, alio-me à suas provocações e concluo esta introdução com um de seus milhares de sonetos propositalmente desagradáveis (e brilhantemente escritos), incitados pela sua ojeriza acadêmica.

\section{Apriorístico}

Não canto aqui, Leitor, luzentes teses que sábios e acadêmicos sustentem. Só mostro onde, na História, os livros mentem e omitem, das paróquias às dioceses.

Consulto do Hermeneuta as exegeses e afirmo: o asco maior que os Homens sentem é o caso em que dum réu no rosto sentem e caguem-lhe os carrascos justas fezes. 
É deste torpe tema que aqui trato, embora desagrade a réus e algozes, ferindo, uns no regalo, uns no recato.

Não sei se irei fazer, Leitor, que gozes.

Porém, dada a crueza dum tal fato,

sugiro-te a leitura em parcas doses. 
Soneto sensorial [418]

Sensíveis todos somos, mais ou menos, mas seres sensitivos, só os pequenos.

Sentir é propriedade material.

A gente sente a forma, o peso, a cor, aromas e calores, doce ou sal.

Filósofos entendem que a verdade não passa de ilusão. Pensamos nela apenas como quem aspira, anela: delírios dum recluso atrás da grade.

Sentir é perceber o que é real, mas é também querer, seja o que for, alguém ou algo, intenso, especial.

Se somos sensuais, quem sabe é Vênus. Serão sentimentais somente os plenos.

Glauco Mattoso

Inicialmente, indicamos a primeira direção do nosso olhar pela sensação. Não há como defender um trabalho a partir da estética senão pela sensibilidade quanto às questões da linguagem. Mas esse olhar, o de leitorpesquisador, atento, que busca conhecer por meio da arte, exige nuanças que, embora perceptíveis, para que se tornem cognoscíveis, requer de nós um diálogo com teorias que discursam e fundamentam sobre as principais inquietudes aqui debatidas.

Por esta razão, neste momento fronteiriço, entre a introdução e a primeira parte da tese, optamos por transitar levemente pelo terreno do diálogo teórico, sem a intenção de acachapar nosso objeto. Usaremos este espaço para esboçar o que nos levou a olhar nosso objeto pelo direcionamento da estética. A ideia de 'construção', intitulada nesta parte, contempla a estrutura analítica da qual nasce nosso alicerce perceptivo, construído pelos diálogos e explorações contextuais do sistema de leitura sensível e análise metodológica. 
E o que seria então esse "leitor-pesquisador"? Claramente, são nas ideias fomentadas pelo grupo regido por Wilton Barroso Filho ${ }^{11}$, que parte nossa concepção de leitor-pesquisador como um arqueólogo do texto - usando aqui um termo de Michel Foucault (1987) -, cujos fundamentos de leitura passam por uma hermenêutica filosófica do texto literário, numa busca de conhecimento a partir das regularidades estéticas presentes na obra. Regularidades que são percebidas pelo movimento sensível da leitura,; pelo envolvimento estético daquele que lê, diante do objeto artístico, que é a obra literária. Ou seja, embora se necessite de uma busca arqueológica e fundamentada para compreensão do texto, nada disso acontece se não partir, primeiro, do olhar sensível.

Conscientemente, usamos o termo leitor-pesquisador sem nos esquecer dos estudos da estética da recepção acerca dos tipos de leitores e suas relações interpretativas e de expectativas com a obra. Mas há de se pensar nas diferenças e no modo como a sensibilidade é conduzida quando se pensa no espectador diante da obra e a interação entre si.

$O$ que Fernandes irá chamar de leitor virtual (ou ficcional), em $O$ narrador do romance (1996), que seria o leitor a quem se dirige o narrador - o leitor fisgado pelo narrador -, é o que compreendemos aqui por um leitor ideal, dirá W. Iser (1996); é sem veleidades, independente se está dentro ou fora da obra. Não é um leitor menor. Mas essa percepção de leitor, mesmo quando não mais virtual, parece contemplar um leitor que está (ou optou ficar) no terreno puro da sensação, sem maiores reflexões e aprofundamentos (o que exige diálogos e teorias) acerca do conteúdo abordado na leitura. Para fins apenas de deleite literário, qualquer um que se debruça sobre uma obra costuma fazer de modo despretensioso, o que é saudável, pois imuniza a ação da leitura como investigadora e truncada aos diálogos teóricos.

Tarde demais para quem se propõe acadêmico e leitor de Glauco Mattoso. Por ser poesia visceral, sua obra requer um olhar um pouco mais vívido, para que se possa transitar pelos motes desdobrados em linguagens, dentro e fora da literatura. Desse modo, ainda pensando em Fernandes (1996),

\footnotetext{
${ }^{11}$ Coordenador e idealizador do grupo Epistemologia do Romance - UnB/CNPq
} 
não nos assumimos como leitores ingênuos, mas, retomando Barroso, como leitores pesquisadores.

Parece paradoxal falar de sensibilidade e, ao mesmo tempo, exigir do efeito sensível compreensão de elementos regulares regidos pela razão, que são compostos esteticamente. Mas é exatamente na busca cognitiva por construção de pensamento e conhecimento por meio da arte que ela mesma, a arte, se propõe como ação transformadora. De que outro modo assumiríamos uma busca à gênese da criação, em seus elementos mais fecundos, sem cair na tentação da interpretação pessoal? (E estamos livres disso?) A observação e análise dos processos estéticos exigem de nós algo além da pura interpretação e especulação. Mais do que isso, lidar com questões da criação que fomentam a figura do autor, em um aspecto autobiográfico, principalmente quando esses aspectos partem do contexto da condição humana, do sexo e da sexualidade, como é o caso de Glauco Mattoso, tende a atrair o olhar da pesquisa para um pseudopsicologismo perigoso, tendencioso, em que as percepções da criação podem cair no espaço redutivo e dedutivo das relações subconscientes do sujeito que cria. E, de fato, essa não é nossa intenção, embora saibamos dos riscos.

É preciso conhecer o que fundamenta tamanhos desdobramentos temáticos, quando escolhidos por seu autor, pensados, articulados e racionalmente elaborados para compor uma obra. Por esta razão, justifica-se nosso insistente viés de análise, o estético, bem como o retorno a autores de uma estética clássica, como F. Hegel, por exemplo, cuja compreensão de seus textos - mesmo que parcial, haja vista a grandiosidade e complexidade de seus estudos - nos leva ao propósito de uma ontologia da arte, tal qual do sujeito que cria.

Pretendemos alcançar nesta tese, por um olhar "gestáltico", um movimento interno e externo de interpretação a partir de reflexões sobre elementos paratextuais e hipertextuais, literários e históricos, que estão intrinsecamente ligados ao texto de Mattoso.

Mas se falamos de processo de leitura, tão caros para esse leitorpesquisador e regidos por uma visão totalitária de obra, embora não linear nem unívoca, é preciso retomar o conceito de Gestalt em F. Hegel, para que o encadeamento processual de leitura seja elaborado. Em virtude disso, é 
importante evocar o verbete, que, no dicionário de filosofia não é trazido de forma específica, mas enquanto uma teoria:

A teoria da Gestalt (do al. Gestalttheorie: teoria da forma) é um princípio psicológico, que se estendeu a outros domínios do conhecimento, segundo o qual não percebemos jamais senão conjuntos dos elementos. (JAPIASSU e MARCONDES, 1996, p.116).

Para André Lalande, o verbete Gestalt é sinônimo de forma. Diz ele em parte da definição: "Forma D. Form (também Gestalt no sentido A); Este termo é quase sempre oposto à matéria. (...)" (LALANDE, 1993, p. 426).

Nota-se que o conceito geral de Gestalt paira sobre os estudos da forma e o terreno da psicologia em torno da teoria da Gestalt, mas pouco se explora do termo enquanto elemento estético, ou no mínimo, de compreensão estética, conforme irá nos sugerir Hegel em Cursos de Estética I (2001).

Para melhor esclarecer, buscamos no dicionário de Hegel uma definição mais fecunda:

1. Gestalt é uma palavra do vernáculo, originalmente derivada de stellen ("pôr, colocar, armar, formar, etc.), mas gerando um verbo próprio, gestalten ("formar, configurar") e, daí, o substantivo Gestaltung para o processo ou produto de tal formação. Uma Gestalt não uma forma abstrata que possa ser compartilhada por várias coisas mas a forma ou um todo morfológico de um indivíduo. Assim, pode referir-se também ao próprio indivíduo formado. Diferentemente de Form, Gestalt não envolve um contraste com "matéria" ou "conteúdo". Os objetos que têm uma Gestalt (por exemplo, plantas, obras musicais, culturas) são concebidos como unidades orgânicas, somente apreciáveis como um todo, não por consideração distinta de suas partes. (INWOOD, 1997, p. 150 grifo nosso).

Sutilmente, emergem as diferenças entre Form (forma) e Gestalt (figura), aparentes na obra hegeliana, e que nos possibilitará dar conta da nossa proposta de análise a partir da leitura e noção de obra, em sentido amplo de produção do autor estudado, que exige um olhar totalitário de suas publicações, para que se possa compreender seu processo de criação enquanto autor maldito. Quanto às diferenças, Gérard Bras foi fundamental, pois, ao discutir em seu livro Hegel e a Arte (1990) questões sobre a estética hegeliana, esclareceu-nos os principais conceitos do filósofo alemão quanto à construção de uma dialética para a criação artística. Bras define o conceito de Gestalt hegeliano, equivalente à "Figura", como 
noção essencial na Estética, visto que designa o elemento sensível em que se manifesta o espiritual, a matéria espiritualizada. Consequentemente, não é jamais um simples dado natural de que o artista poderia lançar mão: o uso que ele faz dessas figuras representativas, miméticas, pressupõe a espiritualização das figuras naturais. $O$ espiritual na arte não pode portanto se manifestar senão numa figura que ele habita, não como se habita uma concha vazia, mas pela atividade de uma configuração dos elementos que é a essência do trabalho artístico, ao termo do qual a figura é em si e por si significante. É essa dialética imanente da figuração e do conteúdo espiritual que determina as diferentes formas de arte. A ambiguidade do termo francês forme é tal que ele serve por vezes para traduzir Gestalt. (BRAS, 1990, p.12-13 - grifo nosso)

\author{
Não só o conceito de Gestalt, mas o de "Aparecer", "Espírito", "Forma" e \\ "Momento" são imprescindíveis para se compreender o processo filosófico da \\ estética hegeliana. Para esclarecer melhor nosso trajeto, elencaremos aqui as \\ definições engendradas por Bras:
}

\begin{abstract}
APARECER (Erscheinen). Esta noção é essencial para compreender o estatuto ontológico da arte em Hegel. O aparecer não é uma simples aparência (Schein). Esta designa o ser do que não passa de mera ilusão da consciência, que toma a imediatez sensível pela essência. Mas uma essência que não aparece, que não toma forma, não é efetivamente. $\mathbf{O}$ aparecer (o fenômeno (Erscheinung)) é pois o movimento pelo qual um conteúdo espiritual, uma essência, dá a si mesmo uma forma sensível, toma figura. $O$ aparecer é então o movimento que pode ser dito de significação, desde que não se perca de vista que a figura habitada pelo conteúdo espiritual não poderia ser arbitrária: ela significa, até em seus aspectos aparentemente desacertados. (BRAS, 1990, p.11-12 - grifo nosso)
\end{abstract}

Nota-se que "aparecer", em Hegel e segundo Bras, é ganhar forma. Não é só ter a aparência de, mas representar por uma forma uma figura. Dessa representação, que, para nós, é a arte enquanto manifestação da razão e do sensível, falaremos mais adiante.

Já o conceito de Espírito (Geist), Bras comenta como

noção tomada em Hegel num sentido absoluto, que ultrapassa portanto os limites de uma consciência individual. Se ela encontra uma expressão na representação religiosa do cristianismo, não se deixa reduzir ao tema de um Deus pessoal, que transcende o mundo. Ao contrário, o Espírito torna-se o que é ao se realizar efetivamente no mundo. Não é um infinito separado do finito; nesse caso, seria um infinito limitado, o que é absurdo. É portanto o infinito que engloba o finito, que se realiza no finito. É o Absoluto, e o 
Absoluto é resultado de si próprio: é a unidade do processo em cujo curso se torna efetivamente o que é em si. É portanto liberdade, concebida não como exercício de um livre-abítrio, mas como realização do racional. (BRAS, 1990, p. 12 - grifo nosso)

Em Hegel, Espírito não possui o significado popular de alma, demônio, fantasma ou equivalências, embora a etimologia da palavra caminhe para essa compreensão. Entende-se que, para o filósofo, enquanto estética, a definição vai além dos princípios etimológicos, pois contempla a ideia de mente, de intelecto do indivíduo. É o Espírito capaz de racionalizar aquilo que não tem corpo ou forma. Em Cursos de Estética 1 (2001, p.57), Hegel esclarece o Espírito enquanto competente da faculdade intelectual da criação.

Como criação necessária de uma forma concreta para dar vazão ao contexto articulado pela mente (Espírito), a noção de Forma desconstrói nossa dúvida acerca da sua sutil diferença entre Gesltat, pois, de acordo com Bras,

\begin{abstract}
Esta noção provém de um uso lógico, segundo o qual a forma é o que compreende um conteúdo, entendendo-se que um conteúdo determinado não pode existir senão numa forma. Disto decorre que o conteúdo advém efetivamente ao dar a si a forma que convém ao que ele é. Assim se passa com as formas de arte (Kustformen), que constituem as três modalidades em que a ideia do belo se diferencia em si mesma. A forma unifica portanto uma diversidade de elementos característicos, neste caso de representação do divino e do mundo e das técnicas de produção artística. Cada forma encerra seus limites próprios, contradição que constitui 0 momento que a põe em movimento rumo à sua superação. (BRAS, 1990 , p. 13 - grifo nosso)
\end{abstract}

A Forma comentada por Bras, elaborada pelo pensamento hegeliano, traz para a compreensão o resultado do efeito semiótico, enquanto um signo maior, que compõe a aparência da obra, que a coisifica, por meio da técnica, produtora do efeito de linguagem, compondo uma estética. Nessa relação aparente da figura, em seu sentido totalizador, ou seja, gestáltico, com os elementos formais que a representa, há um "momento", explica Bras:

MOMENTO (Moment). Esta noção deve ser tomada não num sentido temporal, como designação de um lapso de tempo, mas no sentido que the dão os físicos quando falam do momento de uma força em relação a um ponto, conceito que permite determinar o movimento de um mecanismo simples. É portanto na etimologia latina, que remete a um movimento, que se deve insistir aqui. A noção é 
inseparável da de processo, uma vez que serve para distinguir-lhe os aspectos, as etapas. Não deveria, contudo, ser compreendida unicamente no nível temporal da sucessão. Cada aspecto do processo é de fato duplamente caracterizado: do ponto de vista de seus traços próprios, que lhe conferem sua determinação específica; do ponto de vista da contradição, que o habita e que induz sua negação, sua superação por um momento superior que the exprime verdade. Esta noção é pois o outro aspecto da de ultrapassagem ou superação (Aufhebung). Compreende-se que um momento não pode ser isolado, separado do termo oposto. (BRAS, 1990, p. 13-14 - grifo nosso).

O processo dialético da criação tem em si uma dinâmica própria, explica Hegel, que processualmente é constituída de etapas caracterizadas por elementos de escolha do artista (HEGEL, 2001). Entendido isso, podemos nos atentar às noções estéticas do filósofo para justificar nosso transcurso de leitorpesquisador por elementos que formam e completam a obra de Glauco Mattoso.

As questões conduzidas por Hegel em seus estudos sobre estética compreendem uma reflexão filosófica notoriamente platônica, pois ele pensa num ideal de arte - embora tenhamos imenso cuidado ao buscar uma compreensão do que seria esse ideal, distinguindo-o de um modelo a ser seguido. Em Hegel, o Belo Ideal não é um ideal de produto aos moldes de, mas um ideal enquanto sistema e processo. Ao associar a criação do Belo, ou seja, a arte, por uma perspectiva de ideal platônico, Hegel consegue exigir da filosofia um espaço para se falar da arte enquanto pensamento que se manifesta numa forma e é proveniente de conhecimento, de razão, indo além do efeito causado pela relação sujeito vs. objeto. Enquanto criação humana, a arte depende de uma sistemática, que é estética, logo, sensível e racional, necessitando de condições cognoscíveis para se tornar real, concreta e passível de experiência. Dessa feita, o filósofo rompe com o estigma de que a arte é um fruto puro da sensação e está abaixo do conhecimento racional.

Compreendemos, até o momento, que os esforços de Hegel, naquele contexto histórico do espaço da arte na filosofia, focavam-se na tentativa teórica de esboçar um conhecimento sobre o processo de criação do que ele chamaria de gênio. Isso gera, na atualidade, uma dificuldade de assimilação dos escritos hegelianos, cujas primeiras impressões se fixam, não só no adjetivo complexo usado por ele e outros pensadores, para o sujeito que cria, 
como também para sua compreensão filosófica acerca do Belo na arte. Aqui nos preocupamos em destituir a ideia de genialidade como sinônimo de artista, trazendo para os moldes de interpretação contemporâneos o tratamento geral de artista para todo aquele que produz esteticamente uma obra de arte. Portanto, não nos debruçaremos no adjetivo nem nos conceitos e desdobramentos filosóficos acerca do "gênio".

Ao chegar no conceito de Belo hegeliano, esbarramos naquilo que ele vai conduzir com o Espírito, comentando anteriormente: o Absoluto. Para se compreender o Absoluto buscado na arte, Hegel propõe, pela estética, o estudo da razão sensível, cujo processo não acontece senão pelas três etapas que formam, por um movimento dialético, a obra de arte categorizada como Bela - o que ele vai definir como manifestação sensível da Ideia.

A significação de Absoluto na arte, para Hegel, está ligada ao conceito de verdade. Entretanto, é uma verdade finita, haja vista que é parte da relação perfeita entre forma e conteúdo, mediada por uma Ideia sensível do sujeito, sendo, portanto, possível de alterações e mudanças de ponto de vista, já que é oriunda da experiência, que se renova em cada movimento dialético (HEGEL, 2001). Hegel se valeu de conceitos do Absoluto presentes em Kant, Fichte e, principalmente, Schelling. Dessa feita, ele "conclui que o absoluto não é algo subjacente ao mundo fenomênico, mas o sistema conceitual inserido neste" universo, que é metafísico. (INWOOD, 1997, p. 40).

Esse movimento especulativo numa busca pelo Absoluto, ou seja, na realização final da constituição da obra de arte, vai ao encontro da manifestação da Ideia, essencial para a composição da arte enquanto relação da razão vs. emoção. Dito isso, Hegel nos leva à compreensão de que é pela diferenciação entre Gestalt e Forma que se contempla metamorficamente o pensar a realidade sensível no objeto por meio de uma Ideia (HEGEL, 2001). Ideia esta que, realizada na arte, é perfeita, logo, é Bela, independentemente de sua categoria: a beleza, o feio, o grotesco, o cômico, o abjeto, etc.

Segundo Inwood, "Nos primórdios da filosofia inglesa e francesa moderna, "ideia" e idée passaram a caracterizar uma entidade mental e foram assimiladas a 'representação'” (INWOOD, 1997, p. 169). A Ideia é um conceito (imagem, forma, configuração, aparência) de um pensamento e seu significado, imagem, crença, etc.. Hegel tem a Ideia como variedade de aplicações e 
significações, em que refletem uma complexidade conceitual, pois o conceito é o plano inicial de todo um sistema de conceitos.

Entendido isso, podemos compreender que Espírito (que formalizará a Ideia), Gestalt (como Figura) e Forma (tipos de representação) são as três etapas dialéticas da criação artística. A Forma, nascida da Ideia presente no Espírito, é o que abarca o conteúdo, nas suas mais diferentes representações e técnicas e que, posteriormente, concretiza-se pela totalidade da obra, chamada de Gestalt.

Cartesianamente o processo de criação vai sendo pensado por Hegel e simplificado aqui como uma maneira didática de compreensão da criação literária de Glauco Mattoso. Entretanto, é preciso esclarecer que a sistemática desenvolvida pelo filósofo não reduz a criação a um único fazer artístico, simplesmente porque é infinita enquanto possibilidade e finita enquanto racionalidade. Dito isso, podemos compreender que a ação da criação artística possui um movimento comum, que é de propriedade humana: a da relação de elementos que são sensíveis ao sujeito diante da necessidade de representação linguística, por sua vez, racional.

Em Mattoso, poder-se-ia afirmar que a figuração, enquanto elemento que se repete em toda obra e ganha uma proporção gestáltica é a metáfora do pé, já que a podolatria confessada por ele é reverberada pela feitura literária e ecoa por sua larga obra. Mas essa metáfora, que carrega em si conceitos complexos, é elaborada pelo que Hegel chama de Espírito, compreendido pela formação sensível da Ideia contida na Forma (elementos, unidades ou, especificamente neste caso, romances, sonetos, poesia visual), representada figurativamente pelo contexto da obra. É o Espírito que leva à liberdade da representação do racional por meio da materialização do sensível - que em Glauco, contempla suas particularidades confessadas literariamente - e resolve o conflito entre aquele que pensa, sente e cria e sua condição e sensibilidade, resultantes e figuradas no objeto artístico.

Entendido isso, retomaremos agora alguns conceitos que dão concretude à ideia de leitura gestáltica da obra de Mattoso, mencionados no início desta etapa de construção do leitor: paratexto e hipertexto.

Pensados por Gerard Genette em Palimpsestos (2006), momento em que discorre sobre elementos externos ao texto literário, compostos por 
enunciados diversos, Genette discute e imprime conceitos acerca do plágio, do transtextual, do intertextual, paratextual, hipertextual e metatextual. Especificamente, paratexto se refere a títulos, dedicatórias, intertítulos, epígrafes, prefácios, etc.; já hipertexto está relacionado a outros enunciados textos, ideias, entrevistas - que, de alguma maneira, corroboram para a compreensão da obra literária (GENETTE, 2006) e, neste trabalho, tornam-se relevantes para uma leitura acerca do autor e sua construção estética.

Mattoso, um escritor cuja condição humana é refletida e confessada em todo espaço semântico do que produz, vale-se de entrevistas e publicações extraliterárias que fomentam a personalidade autoral que ele conduz em seus textos. Consequentemente, o autor direciona o leitor a uma busca das questões que estão fora do texto literário, mas que compõem o processo dialógico por ele criado enquanto artista.

Usamos o termo "dialógico" baseados nas discussões de Mikhail Bakhtin acerca do dialogismo enquanto processo interativo de enunciados, em que, na relação do eu vs. outro, o diálogo/discurso é essencial (BAKHTIN, 2014). Embora cientes das divergências conceituais entre a dialética hegeliana e o dialogismo bakhtiniano, nossa postura se valida em pontos de vista que se interligam a partir dos estudos estéticos: por uma perspectiva buscada em Hegel, procuramos compreender os movimentos conflituosos entre as estruturas interna e externa do texto (Gestalt e Forma/texto literário e paratexto); pela perspectiva buscada em Bakhtin, nossa intenção está em entender o diálogo de textos (intertexto/hipertexto) existente no processo de composição da obra de Mattoso.

Esses elementos observados fora do texto literário são parte do contexto da obra e do criador da obra. Entretanto, na posição de leitores-pesquisadores, sabemos dos perigos em se envolver com o contexto e, consequentemente, desvincularmo-nos do objeto em questão: a literatura. Cientes dessas armadilhas, que muitas vezes são conduzidas pelo próprio escritor a fim de manipular o efeito estético (e, consequentemente, intencionar um modelo interpretativo), é que tomamos como processo a compreensão do que transita para fora do texto literário e se confunde com a vida do autor, numa tentativa de elucidar o movimento feito pelas amarras e lacunas da construção literária. 
Ao falarmos de efeito estético na literatura, emerge a discussão empreendida por Wolfgang Iser, em O Ato da leitura (1996), sobre teoria da Recepção. Quando descreve a assimilação dos textos acontecida pela relação entre leitor e obra, Iser destaca o texto literário como originário da relação do autor com o mundo, mas visível e pluralmente compreendido pela perspectiva do leitor diante do texto e o efeito gerado pela leitura. Para o teórico, o efeito estético surge do movimento dialético entre texto, leitor e interação (ISER, 1996, p. 16).

Esse processo interacional é proveniente da estética hermenêutica teorizada por Hans Georg Gadamer (2012), cuja influência está nos estudos fenomenológicos de M. Heidegger e Friedrich Schleiermacher. Gadamer amplia as discussões sobre a relação do leitor com o texto (e com a arte), trazendo como elemento importante a interpretação e o significado, oriundos do contexto do leitor, de suas memórias e história, de seu conhecimento e de sua capacidade relacional. Dessa feita, ampliam-se as possibilidades hermenêuticas, em que o leitor se vê, não diante de um modelo de compreensão, mas de um horizonte das variadas expectativas de leitura possíveis.

Gadamer (2012) enverada para uma perspectiva mais sensível da hermenêutica, deixando-a aberta e dependente de seu jogador e da sua forma de jogar. Ao trazer o conceito de jogo como variadas formas relacionais, 0 filósofo aponta um novo olhar para a relação do sujeito com a obra. Esse sujeito, que pode ou não cair nas armadilhas da intencionalidade ou nas amarras do próprio jogo, é quem precisará compreender quais ações tomar diante desse jogo, pois será por influência dele que o jogador direcionará suas estratégias de compreensão.

Embora as discussões da teoria da recepção destaquem o leitor e a obra como polos geradores do movimento dialético de interpretação, ampliamos nossas perspectivas e incluímos no horizonte de expectativas da nossa leitura, que se propõe contextual, aspectos relacionados ao processo de criação do autor, que são "autobiográficos", de modo a compreendermos, não somente os elementos dos textos formadores de sua poética, mas a estética por ele construída e norteada por elementos de escolha sensível e racional, que se repetem pelo transcurso da obra por um discurso confessional. 
O efeito estético, nascido da relação sensível entre sujeito vs. objeto ${ }^{12}$ (leitor vs. obra) é procedente do imediato, logo, passível de julgamentos a priori, o que, muitas vezes, destitui o objeto de qualquer conceito ou contexto já que todo conceito (conhecimento) virá apenas do sujeito que lê. Precisamos ir além do efeito causado pela imediatez da relação empírica entre leitor e texto para alcançarmos condições de interpretações que estão nas arestas da escrita e da figura do escritor e ultrapassam os limites do julgamento de gosto.

A compreensão do efeito estético na obra literária é fundamental para as discussões aqui empreendidas e carecem de bibliografia que contemple nossos anseios. Voltando a Iser, o efeito estético é substituído pela estética da recepção, em que explica que a escrita, quando ficcional, busca se assemelhar a uma estrutura intencional de leitura, pois não possui um contexto real. Não possuindo um contexto real, invalida-se a relação externa feita com o autor, sujeito que cria, pois, enquanto criador de ficção, seu contexto trazido na obra é falso e tendencioso. Obviamente isso não se encaixa nas leituras da obra de Glauco Mattoso, haja vista sua relação intrínseca com, no mínimo, um dado real: a cegueira do autor, do narrador, do personagem, nas mais diversas publicações. Elementos que se repetem e ecoam para fora do texto carregando a figura do autor escapam das interpretações estruturais e semânticas do contexto interno, exigindo uma relação com um contexto externo à obra. Mas o efeito estético, enquanto efeito, seja ele estético receptor ou estético criador, não deixa de ser efeito, o que se propõe imediato e, possivelmente, livre de conhecimento a priori (ou livre de contexto). Por esta razão, é preciso compreender Kant quando ele fala da ação imediata da arte enquanto despretensiosa epistemologicamente. Como o efeito é imediato, explica o filósofo em Crítica da faculdade de Juízo (2010), o prazer na arte é livre e incondicional e independe do contexto ou de história do objeto. Esse prazer, por si só, fica no terreno apenas da sensação. Mais do que isso, independe de

\footnotetext{
12 Usaremos, em diversos momentos, uma escrita que indique a relação sujeito vs. objeto enquanto menção às primeiras reflexões acerca da estética, da arte e do expectador da obra de arte. Compreender essa relação comporta compreender a grandiosidade da reflexão crítica assumida por Kant, em Crítica da faculdade do juízo (2010), pois é quando se assume, filosoficamente, a relação livre do sujeito com a arte. Contemporaneamente, e nossos estudos levarão também a essa percepção, a relação do sujeito com a obra ultrapassa o modo dicotômico, pois é dialógica, interativa e envolvente, miscigenando e alterando os espaços ocupados por cada lado.
} 
conhecimento, pois nasce da relação pura entre o sujeito que contempla e a obra contemplada.

Entretanto, isso não anseia nossas perspectivas acerca da relação com a obra, seja a do criador ou do leitor, pois limita a compreensão sensível apenas ao contemplativo, sem exigências de conhecer a história desse objeto (sua gênese de criação). Assumimos, desde o início, que nossa pretensão e ir além e conhecer, por meio da obra, condições e intenções do texto que, de certa forma, interferem no processo relacional entre leitor e obra, logo, em seu efeito. $E$ isso só é possível se, ao passar pela experimentação de transcendência entre sujeito vs. objeto, que acontece sem conhecê-lo epistemologicamente, posicionarmo-nos como defensores do possível conhecimento contido no objeto, ultrapassando e transgredindo a anulação de conceitos proposta por Kant, enquanto se tratando do objeto artístico, mas sem excluir questões oriundas do efeito e nem julgando externamente o texto, pois defendemos que nada pode ser interpretado do texto romanesco senão por seu contexto. Dessa feita, há de se retornar ao conceito de transcendência, para darmos continuidade ao processo de compreensão do que seria efeito estético para fins desta tese.

A transcendência, para Kant, vai além da capacidade do conhecimento, pois necessita da experiência. Entretanto, há de se ressaltar que Kant difere transcendência de Transcendental: enquanto a primeira ultrapassa a capacidade de conhecimento, a segunda, enquanto campo da estética, contempla dois conhecimentos imediatos: o espaço e o tempo (KANT, 2015, p. 71-73).

Ao pensar a estética transcendental em Kant, já fora do contexto de arte discutido por ele, agora em Crítica da razão pura, aproximamo-nos de um modo de análise da obra de arte, sem considerar, especificamente, questões pessoais de gosto e efeito. Caso contrário, isso nos daria uma visão simplista e particular da obra. Colocando o objeto literário no plano epistemológico, parece ser razoável a compreensão do fenômeno abstrato de conceitos sensíveis, em que o empirismo que se dá na relação do sujeito com a obra autoriza os conceitos e contextos enquanto possibilidades de busca pelo Belo hegeliano. 
Em Crítica da Razão Pura, Kant, acerca da intuição e sensibilidade, comenta das afetações e modos que nos são dados pelo objeto, em que o efeito acontece empiricamente.

A capacidade (receptividade) de receber representações através do modo como somos afetados por objetos denomina-se sensibilidade. Os objetos nos são dados, assim, por meio de sensibilidade, e apenas ela nos fornece intuições; eles são pensados, porém, por meio do entendimento, e deste surgem os conceitos. Todo pensamento, contudo, seja diretamente (directe) seja por rodeios (indirecte), precisa afinal, por meio de certas características, referir-se à intuição - em nós, portanto, à sensibilidade - pois de outro modo nenhum objeto pode ser-nos dado. (KANT, 2015, p. 71)

Sendo assim, estamos autorizados a assumir como objeto de conhecimento a obra de arte, relacionando o sensível kantiano, presente na Crítica da razão pura com o efeito causado pela obra de arte, presente na Crítica da faculdade do juízo. Em suma, a arte é passível de contexto, de história, de memória e, consequentemente, de conhecimento acerca do humano e suas condições.

Por esta razão, nossa compreensão de efeito estético vai desde o processo intencional de escritura do texto (o autor que quer manipular o efeito causado pela leitura) ao processo daquilo que chamamos de fruição do texto (quando se compreende o efeito causado pela obra e busca meios cognoscíveis de reflexão para além da interpretação do texto). A exemplo, pensamos em Mattoso: um autor que articula sua estética de criação por meio de elementos "reais" e "ficcionais", cujo discurso busca um controle interpretativo do leitor, mas que está além dos discursos transgressores minuciosamente construídos, pois está no espaço da criação artística.

Assumimos, desde o início, que nosso olhar sensível inicial parte justamente do contexto do objeto, formado por outros objetos, permitindo a busca por conhecimento na obra de arte, ultrapassando os limites da experiência sensível, pois busca compreendê-la além de apenas senti-la. A investigação se propõe em torno da noção geral de obra e de elementos que formam epistemologicamente os saberes do autor e como esses saberes são trazidos para dentro do texto literário - saberes estes que compõem uma estética. $E$ isso, inegavelmente, interferirá no efeito causado pela leitura da obra. 
Hegel, ainda em Cursos de Estética I (2001), discorre sobre a necessidade de compreensão dos conceitos que circundam o objeto. Tomamos isso como ponto de partida para compreensão do processo estético entre criador e obra, entre leitor-pesquisador e obra. É importante ressaltar que são movimentos diferentes em torno de estéticas diferentes: a relação sensível entre autor vs. criação e leitor vs. texto. As amarras literárias construídas por Glauco Mattoso só serão identificadas se nos permitirmos essa imersão no seu universo e contexto, no seu tempo e, principalmente, no seu nascimento enquanto escritor.

Mas e o efeito estético? Como ele atua enquanto processo transcendente do sujeito diante da obra literária? Para nossas discussões, temse ficado cada vez mais evidente que é o efeito estético o gatilho para a compreensão do sensível enquanto representação artística. Mas o efeito, por ser imediato, confunde. Pode jogar à frente do processo de leitura questões que impedem a compreensão livre do texto, pois é sustentado por amarras carregadas de conhecimentos a priori, que, quando não deixados em seu lugar, escurecem os dados do efeito e impedem uma racionalidade em torno daquilo que é processual e sistemático: neste caso, a análise literária.

Por esta razão, o olhar de leitor-pesquisador requer da nossa análise, não só uma observação sensível em sua simplicidade contemplativa, mas algo que ultrapasse os efeitos gerados pelos princípios do estético na arte, que, por sua vez, geram um conhecimento sensível, que é contextual e histórico, revelador de uma arte que é metafórica, pois representa questões que são humanas, porém, transformadas esteticamente.

Michel Maffesoli, em Elogio da razão sensível (2008), vai nos falar da metáfora e de uma sabedoria proveniente da contemplação do mundo em que é necessário "deixar-se ser",

para dar conta da globalidade da existência, para exprimir essa obra de arte que é a vida, sabe integrar, em doses variáveis, o zelo estético no próprio seio da progressão intelectual.

(...)

Um saber que deixa a cada um o cuidado de desvelar, isto é, de compreender por si mesmo e para si mesmo o que convém descobrir... (MAFFESOLI, 2008, p. 21) 
O "deixar-se ser" como uma permissão para a expressão sensível do indivíduo, obviamente amplia as discussões que fundamentam a estética, sem negá-las, levando-nos da compreensão do processo de criação estética enquanto atividade racional à relação sensível do conhecimento com o contexto e o instinto.

Consequentemente, falar aqui de contexto e epistemologia na arte, enquanto conhecimento sensível, implica em evocar as discussões que gerou nosso gesto inicial, empreendidas pela teoria da Epistemologia do Romance. Com um grupo em atividade desde 2006, a partir de teses, dissertações e artigos publicados sobre as possibilidades de se compreender o romance por meio de estudos epistemológicos, as discussões empreendidas apontam, cada vez mais, a estética como ponto forte da composição da compreensão literária, pois costura os fios condutores que levam a uma ideia central, presente no conjunto de obra a ser estudada.

Como dito na introdução, são oriundas da dissertação de mestrado "A estética do pé sujo" (2013) as premissas para o desenvolvimento desta tese. Mas o processo das leituras, análise e escrita são resultados de discussões empreendidas pelo grupo ER, com destaque para os trabalhos de Maria Veralice Barroso e Itamar Rodrigues Paulino. O segundo, em especial, debate em sua dissertação "Um olhar sobre a degradação dos valores humanos a partir da obra Os Sonâmbulos, de Hermann Broch" (2006) uma nova forma de conduzir a proposta epistemológica ${ }^{13}$ promovida por Wilton Barroso Filho, até então pensada pelos vieses da literatura e teoria literária, da história e da hermenêutica. Essa inovação trará uma percepção crucial para os desdobramentos futuros das discussões de análise da obra, já comentada aqui: a estética. Paulino (2006) sugere que o processo epistemológico enquanto proposta de leitura, não só literária, mas da arte, busca por um novo tipo de conhecimento, baseado naquilo que ele irá chamar de "epistemologia da sensibilidade".

Já Maria V. Barroso, com sua tese "A obra romanesca de Milan Kundera: um projeto estético conduzido pela ação do Don Juan” (2014) debruça seus esforços na procura por elementos sólidos para uma composição

\footnotetext{
13 Presente em "Elementos para uma epistemologia do romance" (2003) < https://docs.google.com/file/d/0B3rYBdlpwpzbdm5Uc0s3ZE9pVk0/edit>
} 
da estética kunderiana, elaborada pela figura centenária do personagem Don Juan. O trabalho de Barroso tem relevância em consonância com esse, haja vista que as etapas conduzidas pela pesquisadora também partiram do olhar sensível, ou seja, daquilo que chamamos de "leitor-pesquisador", para dar conta dos elementos repetidos no conjunto de obra do escritor tcheco, principalmente enquanto dados de conhecimento sobre questões históricas e da condição humana. Assim sendo, o contexto de pesquisa elaborado agora não seria fecundo se não estivesse interligado com uma discussão sólida e antiga do grupo já mencionado.

Dessa feita, dirá Wilton Barroso:

\begin{abstract}
Seria difícil concebermos a disciplina filosófica à estética, se não houvesse a matéria prima, a atividade artística. Por conseguinte, não haveria epistemologia se não existisse uma atividade científica. De fato, essa moderna disciplina filosófica emerge e desenvolve-se através de uma interação muito forte com as temáticas das ciências; ou seja, tanto do ponto de vista de suas práticas, quanto dos seus discursos e problemas. (BARROSO, 2003, p. 1)
\end{abstract}

As discussões em torno da busca por conhecimento na arte emergiram dos estudos de Barroso sobre os conceitos envoltos das variâncias de significações do termo 'epistemologia', bem como as alterações semânticas sofridas em decorrência de traduções e interpretações do verbete. Conduzido por esse incômodo e pressupondo a epistemologia com um olhar contemporâneo de Michel Foucault, a partir de leituras sobre Diderot e d'Alembert e o apoio da metodologia de Hans-Georg Gadamer, Barroso se permitiu pensar as possibilidades de buscar, no romance, conhecimento revestido de "verdades" dentro da obra.

Mas ER não se volta apenas para o olhar estético. Composta agora por três pilares fundamentais de análise literária, a estética, a epistemologia e a hermenêutica, a teoria de Barroso não contraria as já legitimadas teorias nem as negligencia, mas em um processo somatório, reúne diversas possibilidades interpretativas da obra, sem excluir a figura do autor e, muito menos, o contexto - embora se mantenha o cuidado com os biografismos. Assim, o processo

\footnotetext{
${ }^{14}$ Texto disponível em: 〈https://docs.google.com/file/d/0B3rYBdIpwpzbdm5Uc0s3ZE9pVk0/edit?pli=1〉
} 
investigativo epistemológico garimpa por elementos compreendidos como "verdadeiros" por se repetirem regularmente no conjunto de textos, dialogando com elementos históricos que fecundam o texto e ampliam a ideia de ficção enquanto representação do "real".

A relação entre filosofia e literatura é latente e acontece, para muitos autores, de maneira natural. De fato, pensar o romance (ou a literatura) filosoficamente, do ponto de vista da ER, é trazer à tona discussões acerca do humano e da sua condição, de modo a construir possibilidades interpretativas e de debates sobre questões, muitas vezes, veladas fora do contexto da arte. Muitos autores se revestem da linguagem literária para apontar problemáticas da condição humana, que, elaboradas esteticamente, ganham força e forma pelas palavras, ocupando espaços de discussões e reflexões que levam à transformação do indivíduo fruidor do texto.

A fruição, enquanto produção de sentidos proveniente da relação do sujeito com a obra, sucede o efeito estético, que é imediato, e antecede a reflexão, que é consciente, associativa e interpretativa, logo, transformadora. A arte mantida apenas do terreno da contemplação não consegue promover no sujeito um efeito transformador, pois nega-se, nela, o processo epistemológico de compreensão contextual da obra.

A ER funciona a partir de um olhar atento, de leitor-pesquisador, que, como um arqueólogo do texto, procura por vestígios deixados pelo autor, que conduzem a formação da obra como um conjunto ligado por um eixo estético. Dessa forma, fica claro que, a investigação epistemológica no romance precisa de dois pressupostos básicos: um leitor atento, cuja leitura literária, além de sensível, precisa ser dialógica teoricamente; e a ideia de obra como conjunto de textos, pois, entende-se que, para se buscar elementos norteadores e que se repetem formando uma estética, é imprescindível que o autor estudado permita condições para se pensar em elementos, que só existirão quando se tem um olhar gestaltico do conjunto de obra.

O processo de criação é sensível, tal qual a fruição do leitor diante de um romance ou de um espectador diante de um quadro, por exemplo. Após o efeito estético, é o processo de fruição que leva à possibilidades de transformação por meio da obra de arte, mas ele precisa extrapolar o terreno do sensível e buscar o cognoscível. 
Essas discussões, agora vívidas na obra de Glauco Mattoso, nos leva à indagação: é possível compreender essa sensibilidade, fruto de aspectos íntimos, contextuais e da condição humana, condicionados ao processo da relação de alteridade do indivíduo com aquilo que ele observa/vivencia na arte?

Assumimos ser muita pretensão da nossa parte acreditar que uma análise nos trará uma precisão do processo sensível da criação artística de Mattoso, bem como do efeito gerado entre leitor e obra. Contudo, se essa sensibilidade está traduzida por uma linguagem artística cujos elementos epistemológicos possam ser identificados e interpretados, talvez possamos nos aproximar do processo criativo do artista e do modo como ele constrói sua estética na literatura.

O sistema de criação na arte não parte somente da intuição. Para Fayga Ostrower (1987), o consciente parte de intenções e estruturas compostas por diversos fatores, mas principalmente pela memória, que vai construindo as percepções em diálogo com linguagens, experiências e significações, sistematizando, de alguma maneira, o processo de criação na arte. Logo, a criação literária é sensível e contextual. A transformação pela arte, que acontece por meio da experiência sensível entre leitor e obra, comunga com o não-dito, o não-explícito e o não-intencionado no texto. Mas também comunga com o escolhido esteticamente, o racionalmente articulado pelo escritor, composto senão por sua relação anterior, não só com o sistema racional de criação literária, mas com questões ligadas ao conhecimento histórico e cultural do sujeito que cria.

Dessa forma, providos do olhar aqui construído, daremos início às nossas leituras e reflexões acerca da obra de Glauco Mattoso, em seu contexto histórico e artístico, em busca de melhor compreensão daquilo que defendemos ser uma antiestética. 
Primeira parte

O GLAUCOMATTOSO

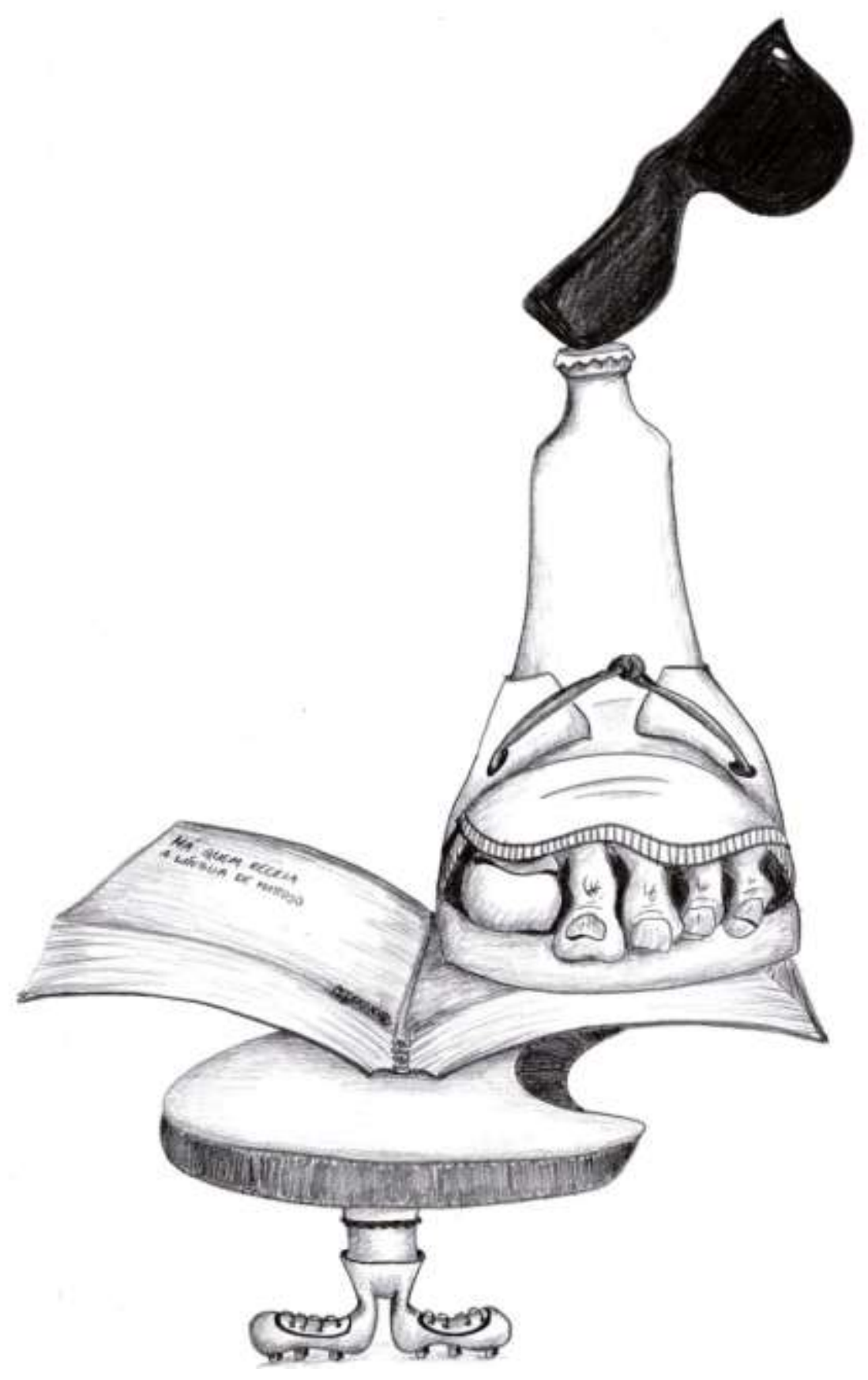

Leitura e língua. Ana Paula Caixeta, 2014. 


\subsection{O Contexto histórico: ditadura militar e a arte marginal}

"E porque o homem se rebela é em definitivo sem explicação, é preciso um dilaceramento que interrompa o fio da história e suas longas cadeias de razões, para que um homem possa, "realmente", preferir o risco da morte à certeza de ter de obedecer."

Michel Foucault, Ética, Sexualidade, Política

(2010).

A concepção de liberdade parece existir apenas quando se tem um contraposto. É preciso estar preso para dar conta da dimensão simbólica do conceito de liberdade. Abstrata e envolta de mecanismos que apenas sugerem a sensação de desprendimento, ela está sempre no desejo hipotético de livre arbítrio incondicional. Mas quando se pensa minimante num estado de exceção e numa ditadura, qualquer cafezinho na esquina com os amigos e despretensiosas discussões sobre política, cultura e arte parecem o maior de todos os idílios. A liberdade, enquanto conceito filosófico, traz uma complexidade grandiosa no que tange o sujeito: a liberdade do corpo, a liberdade da criação, a liberdade do espírito, a liberdade da crença...

Indivíduos de contrários, os que vivenciaram uma ditadura e foram vítimas dessa imposição conseguem observar nitidamente os polos entre a consciência de uma liberdade, que se propõe contextual, diante de uma privação de direitos mínimos. Embora a dicotomia do sufocamento político e anulação democrática pairem sobre o cotidiano daqueles reféns de um sistema imposto, atemporalmente, existe um elemento dialético capaz de transitar pelos dois lados, rompendo com os limites artificiais de alteridade comunicacional: a arte.

Em decorrência excessiva da incidência de momentos cerceados, controlados por uma censura, o Brasil da segunda metade do século XX chega 
aos anos 10 do século XXI com um rótulo enaltecedor: o da criatividade artística nascida durante 0 regime militar de 20 anos. Nada para se orgulhar, haja vista as duras penas para os artistas utópicos de um estado de direito, em que, muitos, para continuarem com sua voz ecoando, tiveram que atravessar o oceano.

Claudia Calirman, em Arte brasileira na ditadura militar (2013), vai se debruçar sobre as obras de alguns artistas, como Antonio Manuel, Artur Barrio e Cildo Meireles, destacando seus esforços para uma compreensão acerca da criação plástica em confluência com a situação política da época. Estudo interessante e colaborador de uma perspectiva sobre a dissidência da arte naquele período, o que nos chama a atenção são as palavras da autora quanto aos aspectos do corpo durante o regime militar. Principalmente, Calirman vai falar de liberdade como exercício, tal qual pensava Mário Pedrosa, junto ao corpo nu: referência fortemente concreta quanto à ideia de escravidão, tortura e silêncio (da voz, do intelecto e do corpo).
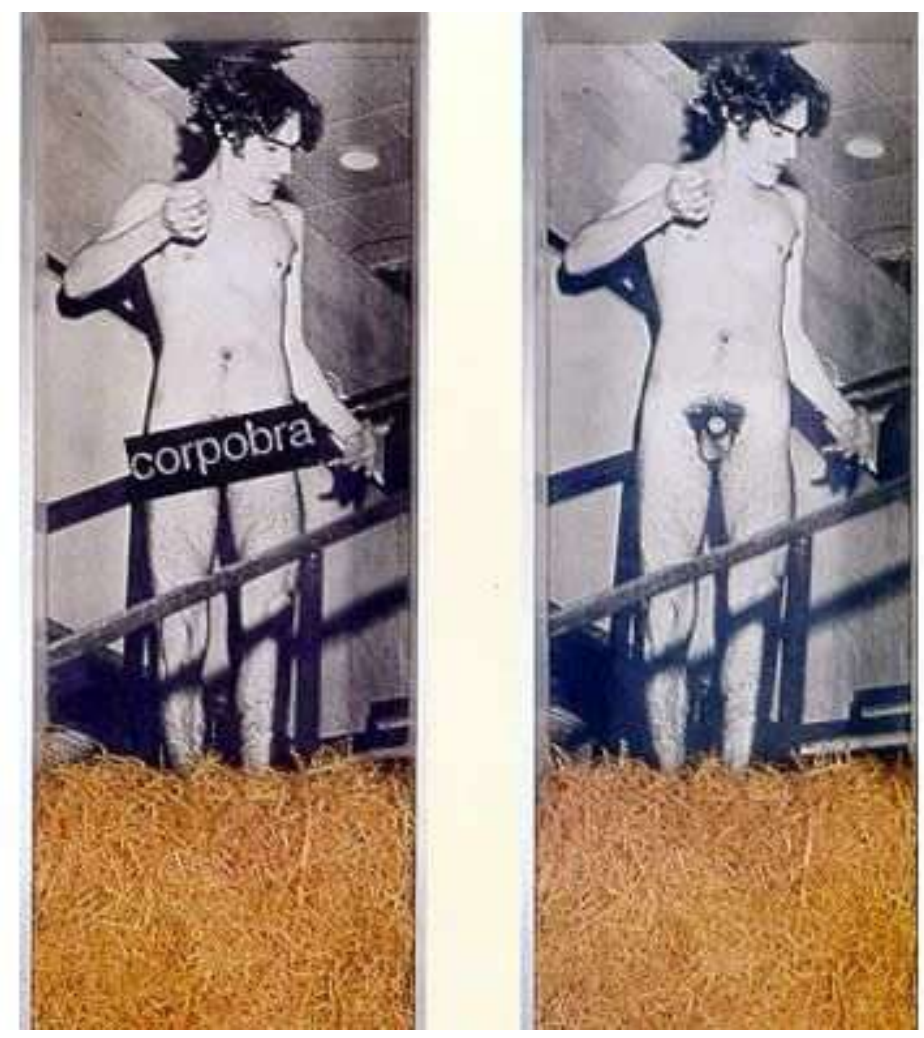

Figura 1. Corpobra, Antonio Manuel, 1970. 
Artur Barrio, com sua instalação Situação (Fig.2) não precisou mais do que lixo para representar a baixeza dada à condição dos corpos silenciados naquele momento.

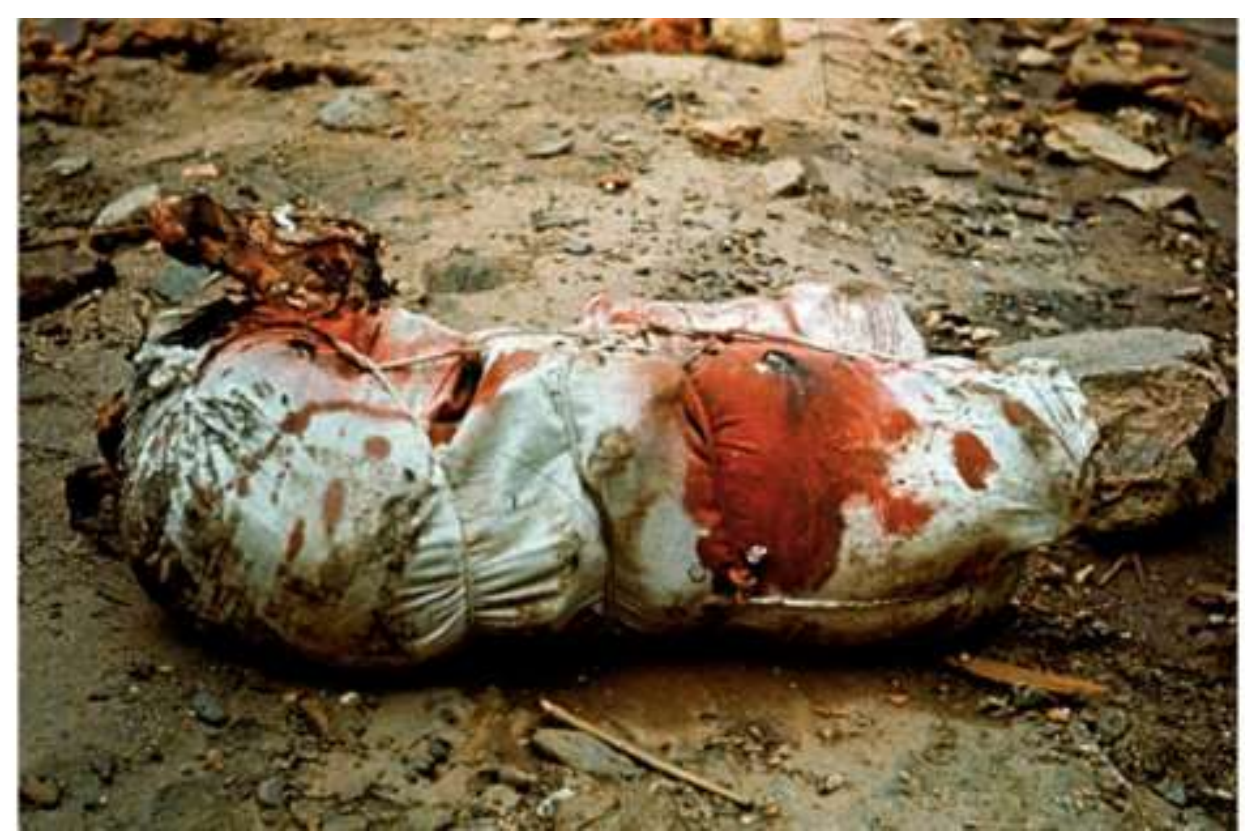

Figura 2. Situação (instalação), Artur Barrio, 1970.

Conveniente, na atual conjuntura em que se vive o Brasil, resgatar discussões do período ditatorial é, talvez, mais que uma ação intelectual de feitura da tese: um exercício de reflexão e busca por memórias de um passado que não pode ser esquecido. Falar de arte, pensamento e democracia, principalmente (e arduamente) comunicação, é assumir a difícil tarefa de diálogos acerca dos posicionamentos da linguagem e seus efeitos enquanto verdades formadoras de opinião, num espaço cada vez mais plural de mídias.

Têm-se um histórico jornalístico-humorístico circulante em contextos de ditaduras, aqui ou em qualquer lugar. Vai dizer Minois, em História do riso e do escárnio (2003), que o riso, embora sofra alterações sígnicas, significativas e conceituais, calcou-se na sua principal propriedade, que é a de ser do humano, para dar conta da seriedade. Embora o significado popular de seriedade dê-se como adjetivo pomposo ao sujeito de moral e bons costumes, é a seriedade das coisas uma ferramenta cortante do instinto humano enquanto livre para sentir e sorrir. Assim, o riso, uma espada afiada, tem que deblaterar contra os sérios discursos para dar conta e sobreviver. Essa seriedade discursiva da qual 
o riso se faz valer, não é a seriedade e importância da temática abordada, visando uma reflexão, mas é uma seriedade falseada, dominadora e controlada por instâncias maiores, tidas como sérias e oficiais.

Enquanto arma democrática, o riso vai encontrar no povo sua morada, amenizando as angústias sofridas pelo excesso de seriedade. Mas é no jornalismo que o riso vai conseguir driblar o controle noticiário, penetrando com seu humor nos mais sérios e sistemáticos discursos. Como exemplo atual, temse o Sensacionalista, jornal virtual que se utiliza da realidade sofrível das notícias tidas como "sérias" e, por uma linguagem absurdamente irônica, destitui o valor empoderador daquele discurso "real" e objetivo, principalmente quando seu teor é político.

Quebrando o poder de vozes opressoras, como a política e a religião, meios de comunicação que se propõem transgressores, há muito tempo, rompem barreiras para ironizar diretamente os silenciadores oficiais. Há tempos se discute os limites do humor neles contidos: pode-se rir de Cristo, de Maomé, do Papa, do rabino, do padre, do presidente, da ciência e de si mesmo?

Embora o riso seja uma ferramenta elementar para se driblar o poder, isso não o livrou da proibição. Do Medievo aos dias atuais, tem-se no riso uma ação poderosa e, ao mesmo tempo, ponderada por sistemas éticos, morais e religiosos. Com a falsa sensação de liberdade de expressão, a ideia de que se pode rir de tudo existe. Entretanto, o riso ainda é o maior silenciado, pois caminha entre o que pode ou não ser dito, o que fere ou não os princípios do outro. O riso vai de encontro aos valores sociais como o do respeito ao individual e coletivo, sustentado pelo politicamente correto. Dependendo de seu teor, pode ser julgado como crime, pois fere princípios do sujeito, perturba e coloca em xeque uma ética e valores morais construídos pela sociedade. Quando articulado esteticamente pela ironia, pode desestabilizar qualquer estrutura sólida de dispositivos de poder - pensando em Foucault (2012) - e, muitas vezes, passar despercebido por aquele de quem se ri.

O jornalismo, enquanto um elemento que é tido, massivamente, como "divulgador da verdade", ao trazer, por meio de uma escolha estética do âmbito humorístico "verdades" diversificadas do que pensa um sistema de poder, 
transgride seu rótulo de imparcial e verdadeiro, sem, por isso, perder sua força jornalística.

O famoso Pasquim, que teve seu auge de circulação durante o Regime Militar e, por meio do humor, embora não tão polêmico e "politicamente incorreto" quanto muitos jornais semelhantes, caminhou no sentido contrário ao da censura. Ele nasce logo após o Al-5, momento em que as restrições civis se tornaram mais severas e a perseguição política, mais efetiva, cruel e, infelizmente, sanguinária. Embora tenha nascido do momento mais sufocante, enquanto cerceamento, da história do país, as charges do Pasquim não se calaram e as críticas aos diversos sistemas ganhavam vida pelos traços de cartunistas e as palavras de grandes escritores, colaboradores do jornal.

Glauco Mattoso também teve sua participação em algumas publicações desse periódico. A inserção do autor no universo jornalístico humorístico é compreendida por nós como sua primeira alternativa para trazer questões sérias - agora a seriedade vem como princípio daquilo que é grave, precisa ser dito e refletido, mas é completamente negligenciado -, que, ao colocadas no terreno leve do humor, abriram brechas para reflexões maiores e discussões em espaços antes inatingíveis. Não é que o autor aqui estudado assuma-se um humorista, nem em tempos de Pasquim, nem na atualidade, com seus sonetos fesceninos e muitas vezes, sarcásticos. Mas foi pelo trânsito por uma linguagem burlesca que Mattoso reverberou suas mais incômodas percepções acerca do não-dito humano, explorado, com maior veemência, pelas linhas literárias.

A imprensa humorística nacional e a produção visual dos chargistas das décadas de 60 e 70, para Ricky Goodwin, demonstra como o humor veio a ser explosivo nas produções jornalísticas, a partir de 1969, principalmente após o lançamento do Pasquim. (2011, p.538) 


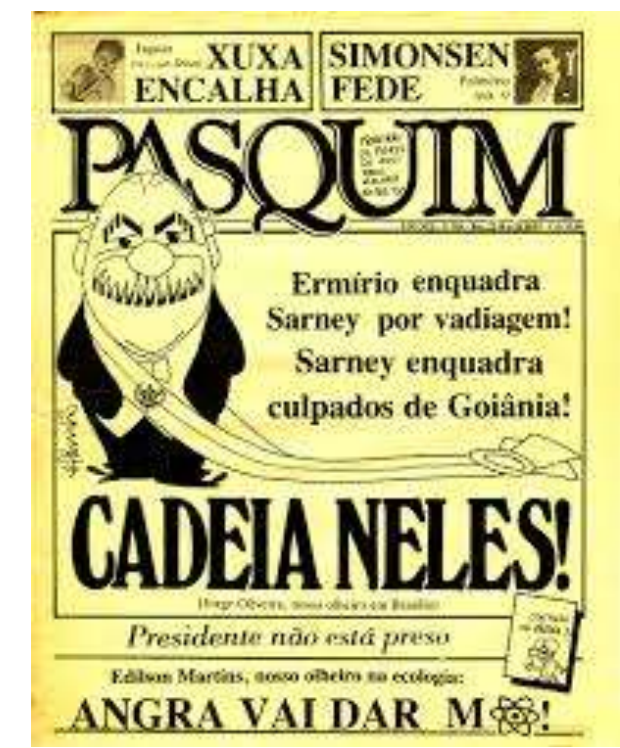

Figura 3.Capa de um exemplar do Pasquim.

A produção humorística desse jornal é também parte do nascimento de uma estética periférica ${ }^{15}$ nacional, cuja estrutura se baseava, conforme comentado, na transgressão da opressão proveniente dos Atos Institucionais impostos pelos militares durante o regime. De maneira geral, essa escrita era conduzida por um riso justificável, podendo ser compreendida a partir do termo aristotélico "meio-termo justo", conforme explica Alain Deligne:

\begin{abstract}
A qualificação é moral, pois haveria um mérito em se dar limites, já que a pessoa que ri ou faz rir estaria sempre tentada a não respeitar nada. Consideraremos aqui a noção de "meio-termo justo", mas com a condição de entendê-la bem, como em Aristóteles: não se trata de um meio no sentido aritmético do termo... Esse meio nada tem em comum com uma meia medida, mas é uma maneira de ser desdobrado em extremos e não tende para nenhum deles. No entanto, podemos observar que Aristóteles não nos deu critérios de delimitação do "injusto", no domínio moral, nem limite pra mais, nem para menos. Definiria, portanto, o meio termo justo como aquilo que devemos buscar; é essa mesma tensão "virtuosa" que definiria, precisamente, a qualidade ética do riso." (DELIGNE in LUSTOSA, 2011, p. 32)
\end{abstract}

O Pasquim, assim como as inúmeras publicações burlescas datadas entre 1960 a 1980 traz uma característica conflituosa no que diz respeito ao julgamento moral daquilo de que se pode ou não rir. Por sua vez, há de

\footnotetext{
${ }^{15}$ Pensa-se no Pasquim como um jornal periférico enquanto discurso, que circulou às margens dos grandes veículos e assuntos dominantes. Entretanto, sabe-se que boa parte dos colaboradores do jornal, pertencentes a uma classe média intelectual, não se enquadravam no que se entende hoje como escrita marginal.
} 
ressaltar que a produção artística pode carregar uma ética transformada em estética, cujos valores morais são internos e próprios da produção, não podendo, portanto, ser deslegitimados ou taxados como injustos. O meio-termo entre o que pode ou não ser dito está na forma como essa estética é conduzida, a ponto de ficar no espaço da criação, sem princípios.

A tensão comentada por Deligne é compreendida como o ponto limite entre a opressão e a liberdade, cujo fator gerado é o comportamento transgressor. Michel Foucault vai dizer que,

\begin{abstract}
Todas as formas de liberdade adquiridas ou reivindicadas, todos os direitos exercidos, mesmo quando se trata das coisas aparentemente menos importantes, têm ali sem dúvida um último ponto de sustentação, mais sólido e mais próximo do que os "direitos naturais". Se as sociedades se mantêm e vivem, isto é, se os seus poderes são "absolutamente absolutos", é porque, por trás de todas as aceitações e coerções, mais além das ameaças, violências e persuasões, há a possilibidade desse momento em que nada mais se permuta na vida, em que os poderes nada mais podem e no qual, na presença dos patíbulos e das metralhadoras, os homens insurgem. (FOUCAULT, 2010, p. 77)
\end{abstract}

Para o filósofo, o processo existencial do indivíduo surge exatamente num ponto de conflito, principalmente por ser fruto de guerras e opressões. A junção de uma situação limite com a construção de saberes do sujeito moderno gerou um novo sujeito, mais consciente de si e, consequentemente, mais autocrítico e exigente. Hoje, o sujeito rotulado "pós-moderno" - cuja dimensão dá-se à compreensão de indivíduo, dirá Maffesoli - é um ser polifônico devido a sua capacidade múltipla de identidades, pois lida com as pluralidades e intersecções dos saberes provenientes de enunciados diversos, articulando-se via a imediatez das informações virtuais e rompendo a unicidade do sujeito moderno.

Esse novo sujeito nacional, emergente de uma situação de tensão entre polos ideais, direita e esquerda, ressoou como um novo indivíduo filho de uma geração que expelia pelos poros uma linguagem exigente de voz, que transgride, que se opõe, que renova e transforma esteticamente. 


\subsection{Imprensa oficial $x$ imprensa nanica}

Sabe-se que a cultura marginal nasce não só do silenciamento imposto por um regime, mas pela exclusão de minorias. É também proveniente das influências da cultura de rua. No Brasil, o que chamamos de cultura marginal, quando datada de 1970 a 1985 e, principalmente, quando o termo é trazido para os estudos artísticos e/ou literários, sua significação parte de uma manifestação contracultural fruto mais da censura enfrentada durante o período ditatorial, que da exclusão de classes, propriamente dita. Dessa explosão em busca de liberdade de expressão nasceram revistas literárias, documentários, peças teatrais, arte postal mimeografada entre inúmeras linguagens estéticas, reflexos de uma juventude conscientemente transgressora e politizada. Em contraposto com a significação popular da marginalidade hoje, têm-se o sujeito excluído: etnicamente, socialmente, artisticamente, culturalmente e intelectualmente. Dessa feita, fica clara a dicotomia da compreensão hoje do que foi a marginalidade setentista com a marginalidade atual. Romanceados pelas atuais interpretações, os nomes daqueles que deblateram contra 0 regime e fizeram sua carreira artística, política e social não se comparam em nada com a marginalidade da criação oriunda de um sistema presente que se propõe desigual, negligente e pouco representativo.

Embora ligado ao contexto da contracultura, Leila Míccolis descreve o viés negativo dado ao termo marginal no Brasil, como

\footnotetext{
elemento de escória, da pior espécie, inculto, perigoso, barra-pesada; também pode ser associado à marginália, movimento artístico tropicalista cuja postura informal, debochada e propositalmente anárquica era vista como alienada pelos setores mais tradicionais, sem entenderem os vários tipos de desbundes como oposição à sociedade tecnocrata, racional e policialesca. Marginal também pode ligar-se à ideia de subversivo, ainda mais que o aspecto da primeira parte da produção (até 76) se parecia muito com panfletos feitos a mimeógrafo, dando-lhe um ar clandestino e, portanto, suspeito... (MíCCOLIS in MELLO, 1986, p. 62)
} 
A manifestação marginal da época ditatorial caminhava contra publicações "legítimas", de caráter oficial, em que o poder político compunha o espaço de informações e consolidava-se enquanto estrutura rígida e poderosa.

O título "imprensa oficial" é usado no país como nomenclatura dos veículos de informações oficiais, oriundas de decisões governamentais de todas as esferas de poder (a exemplo: Diário Oficial da União). Veladamente, tem-se como "oficial", também, a imprensa detentora de direitos de divulgação e veiculação de informações gerais, cujo alcance nacional é grande e, muitas vezes, incontestável. Esse segundo tipo de imprensa foi, também, colaborador do regime, no sentido de ter manipulado toda uma sociedade a partir das construções estilísticas que depunham contra qualquer origem de pensamento comunista.

O Jornal do Brasil, O Globo, Correio da Manhã, Estadão, Folha de São Paulo e o canal televisivo Rede Globo são alguns exemplos de "imprensa oficial" ou "grande imprensa" - pelo viés da "incontestabilidade" diante às informações divulgadas - que apoiaram a deposição do presidente João Goulart - e, atualmente, o processo de impeachment da presidenta Dilma Rousseff - e mantiveram-se em favor da ação dos militares durante o regime.

De receitas de bolo a poemas de Camões, os editoriais manipulados e artigos de notícias, tal qual o conteúdo das rádios, eram substituídos, de modo a ocultar informações que iam contra o sistema ditatorial. A população que não tinha acesso a outros meios, pouco sabia se posicionar diante aos acontecimentos do momento, cabendo tomar partido do veículo de informação de maior repercussão e acessibilidade.

Atualmente, em 2015 e 2016, com o fervor das manifestações no país, cujo lema é a anticorrupção, muitos trazem frases risíveis em favor de um novo regime, a partir de uma intervenção militar. É notório que boa parte dos discursos adotados por esses simpatizantes é fruto de uma construção midiática e não demonstra muita profundidade de conhecimento no que diz respeito aos reais acontecimentos dos 20 anos de ditatura.

Na educação básica, basta um mínimo olhar sobre os livros de história para se notar as pouquíssimas páginas destinadas a essa parte do passado nacional. Os jovens constroem suas identidades em cima de uma lacuna, de um vazio, de ausência de explicações sobre como e por que as coisas 
aconteceram. E mesmo com a infinidade de informações disponíveis na rede virtual, a ausência de autonomia de pensamento político impede a busca e construção de uma opinião a partir de outras opiniões, divergentes do que a grande imprensa sempre propôs.

Problemas educacionais à parte, o que de fato interessa aqui é como uma imprensa nanica conseguiu, por meio de uma voz emergida no meio de uma multidão castradora, alcançar jovens e apresentar um outro lado da realidade ditatorial, durante, talvez, o momento mais opressor do país.

A expressão "imprensa nanica" refere-se à imprensa alternativa que circulou durante o Regime, composta por jornais artesanais e de pequena circulação, em se comparando aos grandes veículos da imprensa. "Também chamada de independente, do leitor, popular, a imprensa alternativa sempre existiu no Brasil, embora somente tenha sido batizada com este nome no início da década de 70". (BUENO in MELLO, 1968, p.47)

Desde revistas literárias universitárias aos jornais homossexuais, vozes de uma minoria ecoaram e alcançaram leitores, permitindo reflexão em torno dos acontecimentos políticos e, principalmente, a consciência individual num período de anulação do sujeito e da coletividade.

Moreira explica que

\begin{abstract}
Ser alternativo no início da década de 1970 significava produzir fora da zona de influência direta do Estado ou à margem do aparato industrial que cercava qualquer produto antes e depois da sua entrada no crescente mercado consumidor. As descobertas de novos caminhos acontecem simultaneamente mas sem premeditação e envolvem grupos de poetas, músicos, atores, diretores de cinema, artistas plásticos, principalmente. Ao mesmo tempo, a impresna chamada alternativa se fortalecia como canal de informação, apesar de estar sob a vigilância de censores cada vez mais severos. Foram os jornais nanicos que, na maior parte das vezes, funcionaram como os principais veículos para a divulgação das novas propostas e tendências que estavam se cristalizando em trabalhos dos mais variados tipos e inspirações. (MOREIRA in MELLO, 1986, p. 30)
\end{abstract}

Muitos desses jornais traziam como elemento primário o riso. Pelo efeito destronador, burlavam a censura, principalmente pela dificuldade de enquadramento de transgressão. As variâncias entre a permissão e a proibição eram parte de poderes instituídos pelos militares, em que a transgressão, 
enquanto natural da pulsão humana, ficava condicionada aos mecanismos de liberação. Como exemplo, acontece com o grupo Dzi Croquettees ${ }^{16}$ (Fig. 4, que, por falta de compreensão da censura, não foi impedido de se apresentar $^{17}$. Com um humor híbrido e uma estética perturbadora, o Dzi Croquettes conquistou público no Brasil, EUA e Europa rompendo com todas as amarras morais de uma sociedade brasileira que, hipocritamente se colocava em prol da família e dos bons costumes.

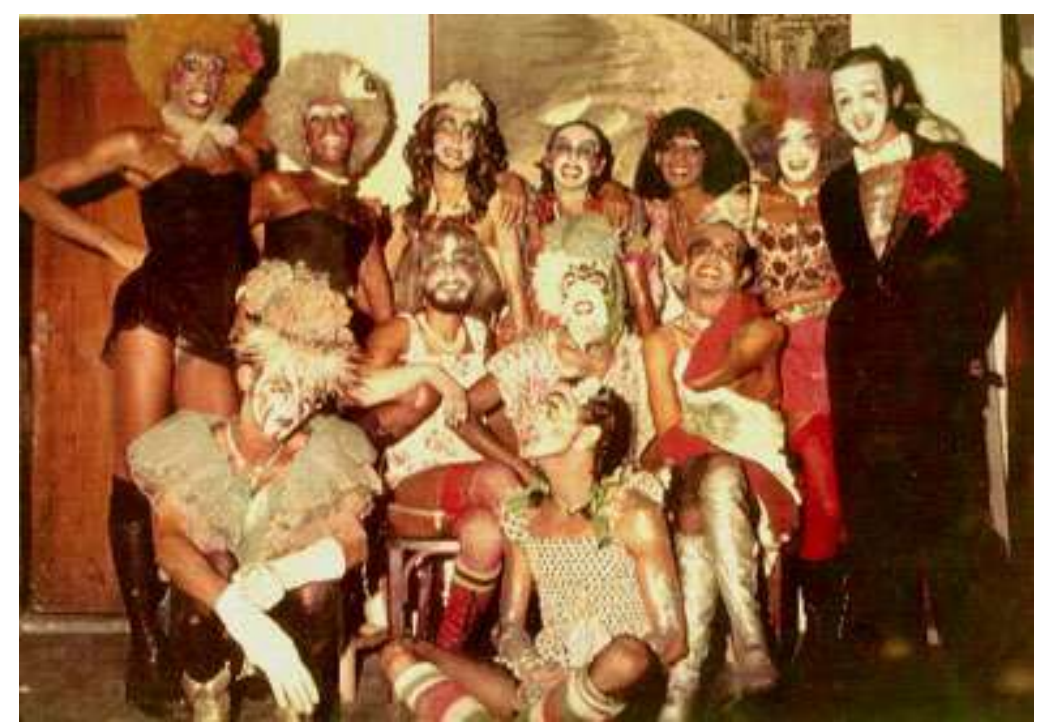

Figura 4. Grupo Dzi Croquettes, 1973 - 1976

Outro tipo de veiculação de arte e informação foram os poemas postais e a arte mimeografada. Publicações de linguagens diversas eram elaboradas a partir da criatividade surgida em meio à tensão da proibição. Grandes poetas como Cacaso $^{18}$ (1944-1947) e Paulo Bruscky ${ }^{19}$ (1949 - fig.5) inauguraram uma

\footnotetext{
16 "Grupo carioca irreverente, alinhado à contracultura, à criação coletiva e ao teatro vivencial, que faz do homossexualismo uma bandeira de afirmação de direitos. (...) Inspirado no conjunto norte-americano The Coquettes e no movimento gay atuante na off-Broadway, a equipe utiliza equacionar conteúdos brasileiros para falar de nossa realidade, desde a repressão sexual até a censura e a ditadura. $\mathrm{O}$ grupo está na origem de uma corrente que veio a se desenvolver algum tempo depois, vinculada ao travestismo, ao deboche, à exploração do virtuosismo dos membros do elenco, à caricatura, à farsa e à comédia de costumes." Disponível em: < http://enciclopedia.itaucultural.org.br/grupo399377/dzi-croquettes>

17 Informações contidas no documentário "Dzi Croquettes", Direção de Tatiana Issa e Raphael Alvarez (Brasil, 2009), disponível em: < https://www.youtube.com/watch?v=rgy8fXEqw98>

${ }_{18}$ (1944 - 1987) Foi poeta, professor e ensaísta, colaborador nos jornais cariocas Opinião e Movimento. Também participou dos movimentos estudantis contra a ditadura militar. Informações disponíveis em: < http://enciclopedia.itaucultural.org.br/pessoa20598/cacaso>
} 
nova forma de poesia, mais conceitual, cujos mimeógrafos e as máquinas de xerox eram as principais formas de divulgação.

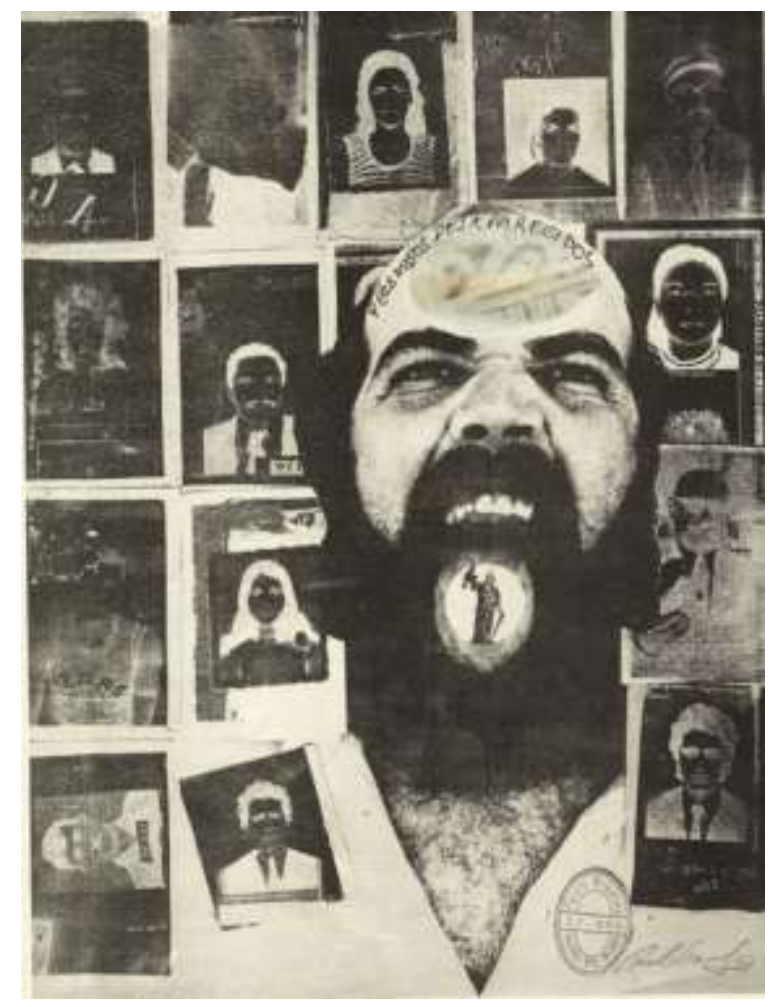

Figura 5. Arte postal. Paulo Bruscky. Disponível em $<$ http://www.amparo60.com.br/paulo-bruscky/>

Esse tipo de veiculação artística, cuja propagação se dava de maneira artesanal e não se tendia às grandes impressões e editoras, reflete 0 comportamento dos artistas da época em não se comprometerem e, de fato, burlarem um sistema censurado de divulgação. A antiarte ${ }^{20}$ defendida por Hélio Oiticica $^{21}$ começa a proliferar por todos os espaços de criação no país e a bandeira da marginalidade ganha voz e força na arte contracultural.

19 Artista multimídia no campo da arte setentista, nascido em 1949. Sua atuação mais expressiva foi na Arte Postal, sendo um dos pioneiros no Brasil. Informações disponíveis em: < http://enciclopedia.itaucultural.org.br/pessoa7783/paulo-bruscky>

${ }^{20} \mathrm{O}$ que chamamos de antiarte parte, também, de concepções provenientes da estética dadaísta, pensando em Tristan Tzara e Hans Richter, principalmente quando associada a um estilo "polêmico-literário" (RICHTER, 1992, p. 1)

${ }^{21}$ (1937-1980) Artista performático, pintor e escultor; realizou uma manifestação coletiva a partir dos seus Parangolés (obra de interação entre objeto de arte e público). A partir da sua obra Tropicália (1967), apresentada no Rio de Janeiro, Caetano Veloso se apropria do termo e cria o movimento musical Tropialismo. Informações disponíveis em: < http://enciclopedia.itaucultural.org.br/pessoa48/helio-oiticica> 


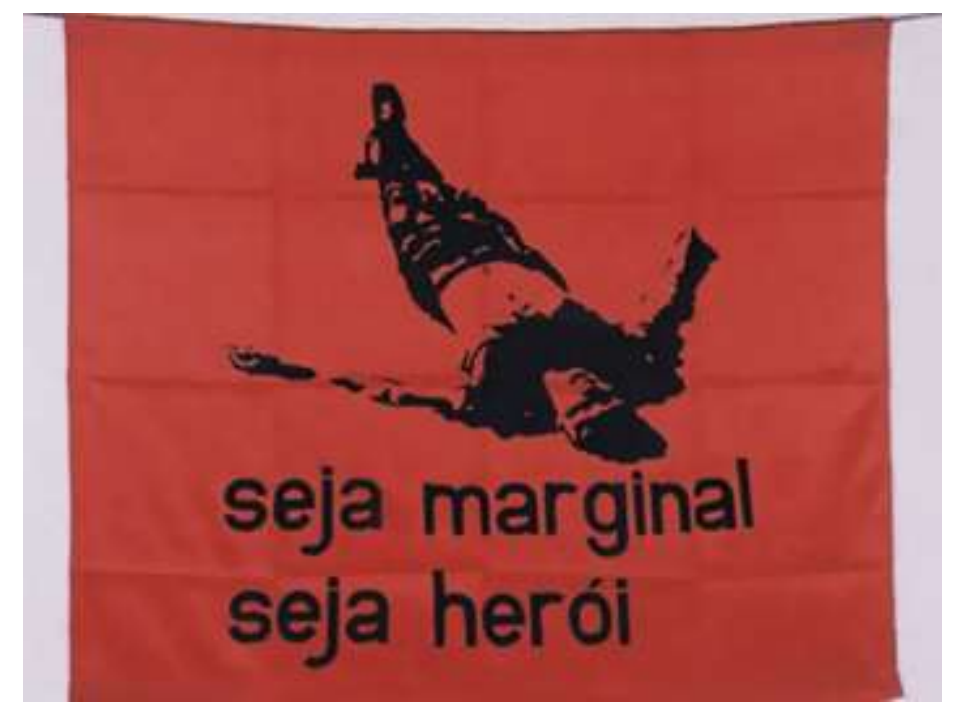

Fig 6. Bandeira de Hélio Oiticica, 1968

Em todas as esferas, os artistas criavam seus mecanismos para propagação de seus trabalhos, agregando estéticas já comuns em outros países, como a mail-art (arte postal) e o ready-made (fig. 7). Criado por Marcel Duchamp, o ready-made é combinação articulada de apropriação de objetos industrializados, ressignificando-os como objeto artístico por meio do discurso.

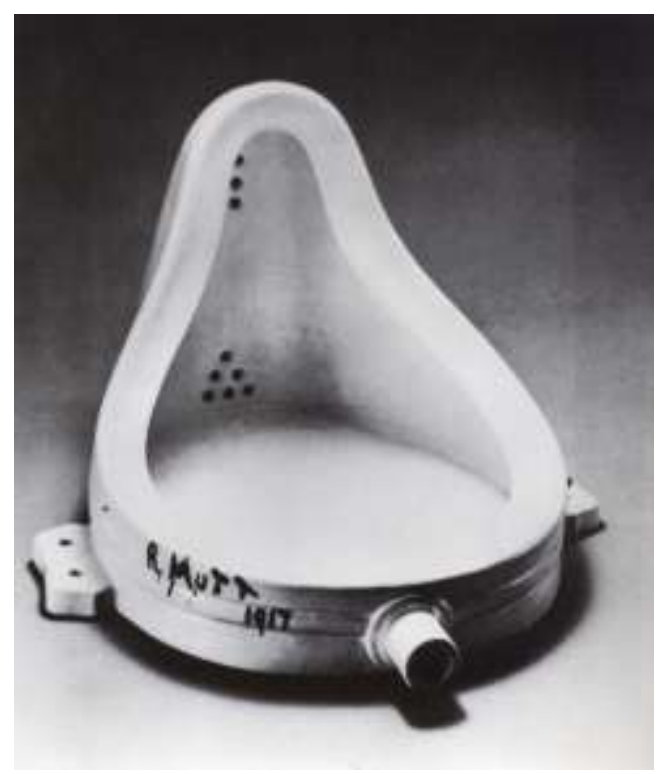

Figura 7. A fonte. Marcel Duchamp, 1917.

As múltiplas formas de distribuição de trabalhos impressos artesanalmente, bem como as explorações estéticas de diferentes formas artísticas foram determinantes nas influências sofridas por Mattoso, tempos depois identificados na elaboração do folhetim JORNAL DOBRABIL. 


\subsection{Glauco Mattoso e a escrita homossexual ${ }^{22}$ durante o regime militar}

Quando um fato é publicado, pode ser boato. Quanto um boato não pode ser publicado, é fato.

Glauco Mattoso - JD

O livro mote desta tese, Manual do podólatra amador, cita algumas das principais publicações periódicas de caráter homoerótico do período da ditadura militar. Glauco Mattoso, um transgressor nato e narrado por ele mesmo, coloca-se, na trama, como um colaborador de muitos desses folhetins, com destaque para o jornal Lampião da Esquina - o famoso tablóide guei (para utilizar a grafia dos militantes da época) de maior repercussão no país. Ele circulou entre os anos de 1978 a 1981 e surgiu em meio ao contexto da imprensa alternativa e do afrouxamento dos atos de censura promovidos pelos militares.

Neste espaço de tempo, Mattoso, já um engajado na "causa guei" tornase um colaborador do tablóide e em sequência, dá vida ao seu próprio jornal, o JD, que tinha como suplemento a Revista Dedo Mingo, que serão comentados posteriormente.

Mattoso também escreveu ensaios, críticas literárias, poemas, etc. para diversos periódicos nanicos da época, cujo teor não se opunha ao do Pasquim e Lampião. As revistas Chiclete com Banana, Tralha, Mil Perigos, Som Três, Top Rock, Status e Around são algumas descritas no Manual e relatadas em entrevistas do autor.

O livro de Green e Quinalha, Ditadura e homossexualidades repressão, resistência e a busca da verdade (2014), uma publicação, até então, inédita no país, traz a escrita marginal homossexual durante a ditadura militar e os olhos do regime para esses grupos identitários. Os textos são compostos por discussões sobre subversão, homossexualidade, transexualidade, opressão e liberdade, mas, principalmente, de registros dos grupos e movimentos da época, em que a luta pela causa LGBT começa a ganhar

22 Consiste, enquanto contexto de ditadura militar, numa escrita com discussões homossexuais, no âmbito da arte, da cultura, da identidade e representatividade. 
espaço justamente pelo advento da imprensa alternativa. Ele nos interessa aqui por ajudar a compreender a relação da escrita glaucomattosiana com esse movimento e suas publicações, e como eles eram recebidos e interpretados socialmente.

De fato, a ditadura, ao amordaçar seus filhos, produziu neles uma necessidade de criação, de subversão, de rompimento com aquilo que é incômodo, incluindo aí discussões acerca do sexo e da sexualidade. A criação pulsa e exige ser expelida, seja proveniente da dor, do sofrimento, da opressão, da exclusão.

A escrita brasileira contemporânea está marcada pelas visões do Golpe, principalmente quando escrita por artistas que vivenciaram esse momento da história nacional. Em contrapartida, apesar da quantidade excessiva de depoimentos confessionais de quem sofreu com o regime, seja com a tortura, exílio ou qualquer sentimento patriótico diante das fatalidades oriundas de um sistema repressor cruel, não há grande espaço para se falar da homossexualidade e como ela, de certa forma, foi elemento condenado diante de um sistema que pregava "a família, a moral e o temor a Deus".

A perseguição aos homossexuais foi condensada ao que eles chamavam de "prática do saneamento", ou seja, a limpeza dos subversivos. Num país em que a família marcha pela defesa de moral e bons costumes em nome de Deus, qualquer homossexual, principalmente efeminado, era diretamente ofuscado pelos julgamentos opressores, humilhantes e resignadores. (GREEN e QUINALHA, 2014)

A prática homossexual era uma conduta escandalosa e perigosa, sendo, portanto, também motivo para algum tipo de perseguição que levava a falsos julgamentos políticos e resultava, muitas vezes, em tortura e morte - embora a causa para tais ações estivesse justificada, por escrito, como de teor comunista.

Em meio a esse preconceito baseado na contrariedade do militarismo à ideia de Feminismo e Liberdade sexual, inúmeros grupos homossexuais foram criados, na surdina, para discutirem sobre seu espaço, suas preferências e pluralidades identitárias, unindo vozes e forças sobre discussões latentes de uma sociedade em transformação. Em destaque, têm-se o grupo SOMOS: 
Grupo de afirmação homossexual, o primeiro em busca dos direitos LGBT ${ }^{23}$. Sobre o grupo, vale dizer que Mattoso afirma ter sido membro e ajudou a escrever o estatuto, segundo informações contidas no Manual.

Cada vez mais se via uma necessidade de falar sobre aquilo que os homossexuais eram julgados socialmente, embora não tivessem espaço para isso. A impressa oficial, principalmente à ligada ao regime, jamais daria espaço à "perversão sexual" oriunda da homossexualidade. Isso, para boa parte da sociedade brasileira, foi e ainda é uma prática "demoníaca" - uma espécie de terceirização de culpa de um comportamento não aceito.

Foi nesse momento que os grupos marginais LGBT sentiram a necessidade de se reunir e falarem mais sobre essa temática, de forma a divulgar pensamentos, atualidades, comportamentos relacionados ao grupo homossexual - ação inédita, já que, quem se assumia não via nenhum tipo de leitura direcionada a esse público em específico, muito menos, espaço comunicacional de compartilhamento e troca de experiências.

Nos 20 anos de resistência, houve perseguição, tortura e morte aos grupos que se formavam para discutir ideias (e ideais) antiditatoriais. Utilizar-se de artifícios para driblar essa perseguição pelo humor foi, de fato, o caminho mais fácil. Como uma das armas estéticas, o humor conseguiu, por meio da sátira, romper a barreira mortal entre a moral defendida pelo regime e a transgressão vivenciada e repercutida pelos artistas da época. Nesse ínterim, o destaque vai para o tablóide Lampião da esquina, lançado 14 anos após 0 Golpe Militar.

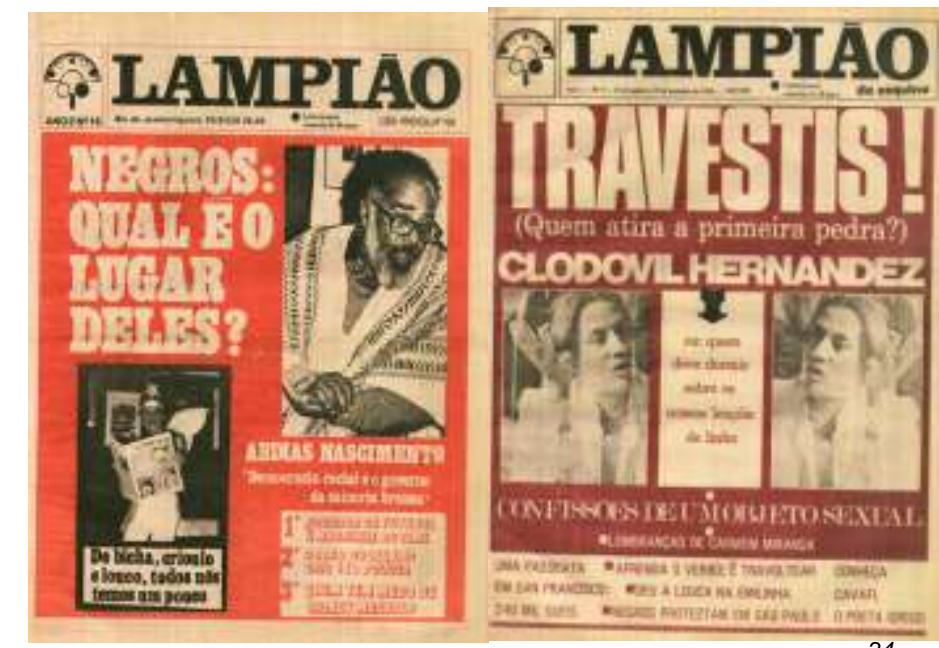

Figuras 8 e 9. Capas do jornal Lampião da Esquina ${ }^{24}$

${ }^{23}$ Esta sigla foi criada tempos após o período do regime. 
Com o primeiro editorial do jornal, a perspectiva em relação aos rumos que o país caminhava era positiva, principalmente em se tratando de novos discursos e novas vozes, embora se saiba que discursos divergentes da heteronormatividade, ainda hoje, não ocupam o espaço que precisa e deveria. Descreve Green,

Brasil, março de 1978. Ventos favoráveis sopram no rumo de uma certa liberalização do quadro nacional: em ano eleitoral a imprensa noticia promessa de um Executivo menos rígido, fala-se da criação de novos partidos políticos, de anistia, de uma investigação das alternativas propostas faz até com que se fareje uma "abertura" do discurso brasileiro. (GREEN, 2014, p. 177 - trecho do editorial do primeiro Lampião da Esquina).

Para Green, esse editorial trouxe uma postura importante

de rompimento da máscara de proteção que os gays e as lésbicas haviam criado para si nos anos 1950 e 1960, sobretudo para garantir um pouco de sociabilidade longe dos estigmas sociais que marginalizavam as pessoas, dos conceitos médicos que tratavam a homoafetividade como doença e da moral católica que considerava a homossexualidade um pecado. (GREEN, 2014, p. 177)

O jornal Lampião da Esquina, mais do que operar contra um tipo de imprensa opressora e resignadora, assumia seu papel social de defesa de um direito humano fundamental e legítimo, obrigatoriamente ocultado pelos silenciadores morais. Ao fazer parte do grupo de alguns dos criadores do Lampião, como Darcy Penteado ${ }^{25}$, Mattoso não só assume uma postura em favor dos direitos homossexuais, como também se reconhece enquanto sujeito homossexual e abre espaço, na sua literatura, para a escrita de teor homoerótico, embora desestabilizada pelo teor fescenino.

A relação de Mattoso com a imprensa nanica caminha ao encontro das publicações visuais de poesia datilografada e de parceria na composição de HQ's, reforçando sua influência quanto à relação palavra-imagem. Muitos chegam ao escritor brasileiro, não pelos seus sonetos e romances ou qualquer relação com a escrita homoerótica, mas por sua participação efetiva no terreno

24 O grupo Dignidade disponibilizou, digitalmente, todos os exemplares do jornal: < http://www.grupodignidade.org.br/projetos/lampiao-da-esquina/>

25 "Darcy Penteado (1926-1987), foi artista plástico, figurinista e literato, militante pioneiro da luta LGBT, sendo um dos principais colaboradores do jornal Lampião da Esquina. Dedicou-se anos à arte indumentária. Informações disponíveis em < http://darcypenteado.blogspot.com.br> 
das publicações humorísticas, como foi o caso da Revista Chiclete com Banana (fig. 10). Ela circulou entre as décadas de 1980 e 1990 e, em 2007, sua antologia foi lançada em 16 volumes.

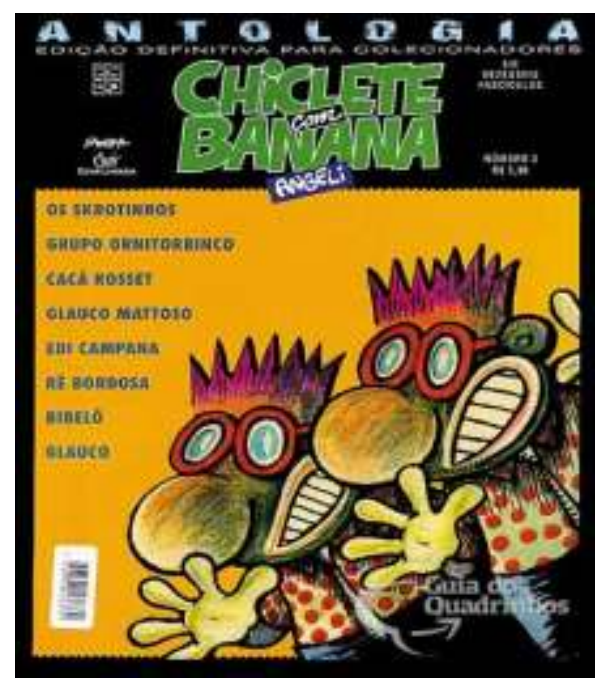

Figura 10 - Antologia da Revista Chiclete com Banana, v. 3, 2007.

A revista ficou famosa ao reunir três dos maiores cartunistas do país: Glauco $^{26}$, Laerte e Angeli, que traziam temas variados dentro do universo chamado "underground" - termo comum da época, usado para caracterizar estilos transgressores em HQ's e na música, especialmente.

\subsection{Publicações anarcopoéticas}

\section{O JORNAL DOBRABIL}

"Minha obra nada mais é que um desabafo de uma condição de inferioridade

que acabou se alastrando e contaminando as outras coisas que eu fiz." Glauco Mattoso ${ }^{27}$

\footnotetext{
${ }^{26}$ Refere-se ao cartunista Glauco, assassinado em 2010.

${ }^{27}$ Entrevista com Glauco Mattoso, disponível em <http://www.memorial.org.br/cbeal/poetas-nabilbioteca/glauco-mattoso/entrevista-mattoso/>
} 
1977: o nascimento do JORNAL DOBRABIL. Como vimos até aqui, qualquer dia de qualquer mês de qualquer ano entre 1964 e 1984 não passou despercebido pela escrita jornalística e literária, seja para enaltecer o regime ou contrariá-lo. A ditadura de 20 anos está impregnada nas veias, imagens e letras da memória artística e da comunicação nacional. Com Glauco Mattoso não foi diferente, embora seu projeto nunca tenha sido o engajamento. O JD, pelo simples fato de usurpar a linguagem alheia, já era político por natureza.

Falamos até agora de algumas publicações marginais da época e de temáticas homossexuais. Esse contexto começa a dar forma na escrita literária de Mattoso, que trouxe consigo elementos de temas sexuais, transgressores e excluídos do espaço de publicação oficial. Em meio às colaborações satíricas e participação em grupos variados, GM cria o seu próprio panfleto, que ele mesmo chamará de anarcopoético.

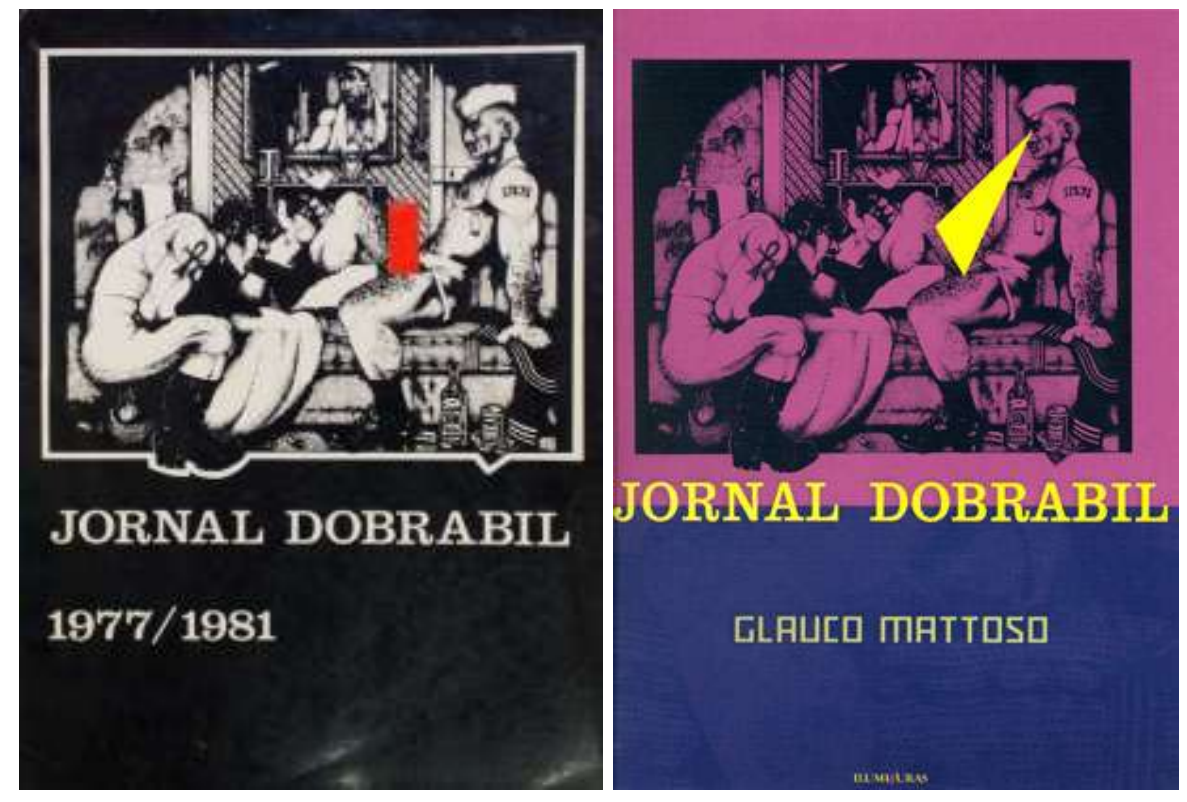

Figuras 11 e 12 - Capas do Jornal Dobrabil, 1981 e 2001, respectivamente.

As imagens acima são das duas edições fac-similares do JD, publicadas, uma em 1981 e a outra, 20 anos depois, em 2001.

Falar do Glauco Mattoso implica, necessariamente, falar do JORNAL DOBRABIL. O resultado desse jornal reverbera na imagem literária do poeta atualmente. É um folhetim fruto de influências e características das 
manifestações artísticas da época e traz, como elemento principal de construção, o pastiche.

Segundo Tiphaine Samoyault, em $A$ intertextualidade (2008), paródia e pastiche são conceitos próximos, que, de acordo com Genette, carrega a relação de um texo (hipertexto) com um texto anterior (hipotexto), enxertados e não comentados. Explica Samoyault que: "O pastiche também deforma, mas imitando o hipotexto, enquanto a paródia o transforma. Trata-se menos de remeter a um texto preciso do que ao estilo característico de um autor, e, para isso, o sujeito pouco importa." (2008, p.55)

As publicações de luxo do JD são compostas por todos os folhetos reunidos, cuja sequência de publicação e distribuição apenas Mattoso conhece. O título é um denunciador da paródia feita com um dos principais jornais da época: O Jornal do Brasil, que se posicionou, deliberadamente, em favor do Golpe.

Glauco produziu folhetins, separadamente, cuja organização imitava a de um jornal comum. Desde a composição das chamadas e olho de notícias aos complementos de jornais, o DOBRABIL se mostrou firme na caracterização caricata da produção de um veículo sério de informação.

Os colaboradores, muitos heterônimos criados por Mattoso, dão credibilidade ao jornal e sustentam a ideia de um veículo de informações legítimas, embora se contraponha em linguagem e é transgressor, conforme observamos na figura a seguir (13). 


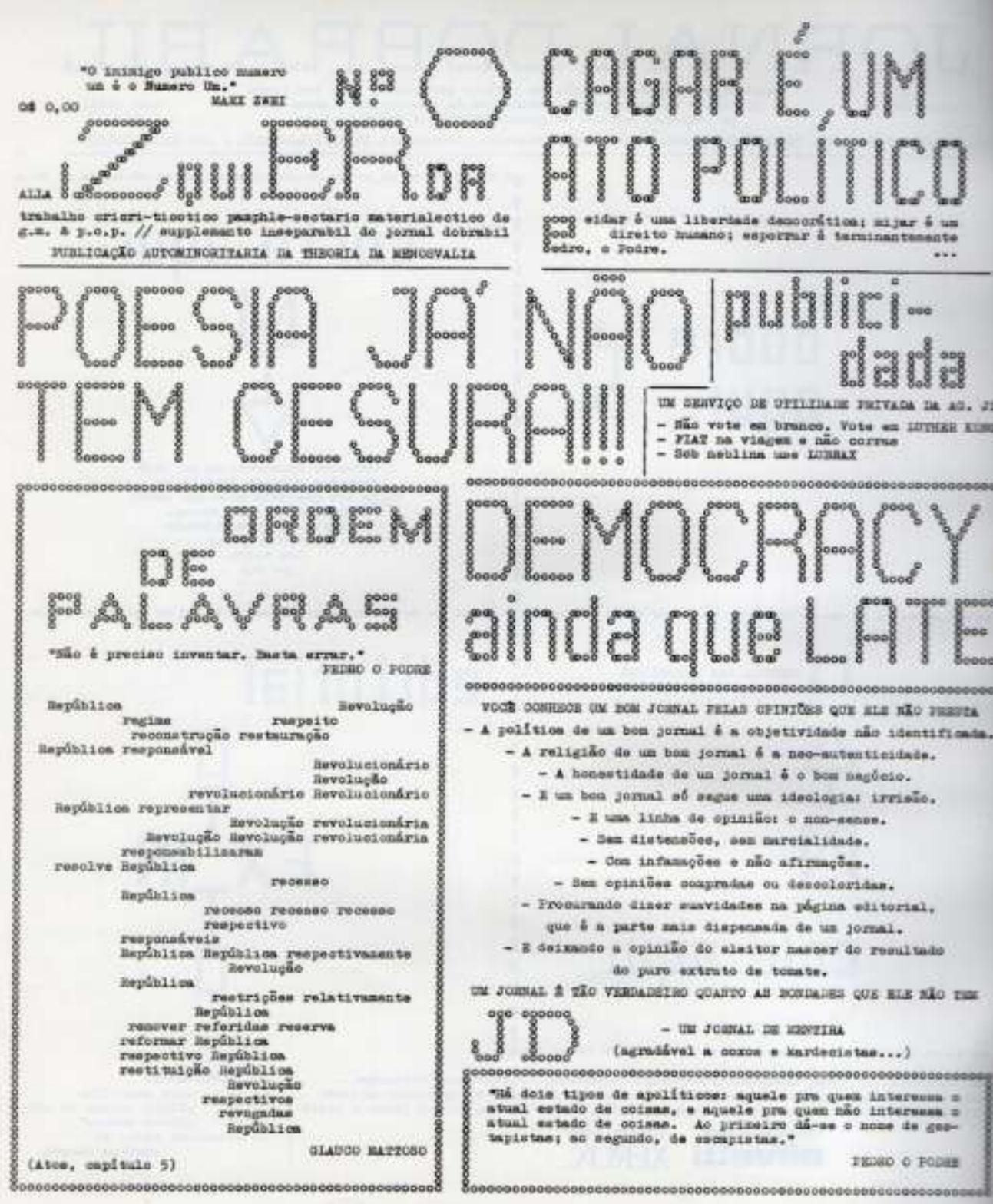

Figura 13. Página do Dobrabil - sem indicativo de página e data de publicação (2001)

Começando pela organização do folheto: não há organização precisa. São folhas avulsas, enviadas a destinatários específicos, escolhidos com critério pelo autor. Segundo Mattoso, em "Uma odisseia no meio do espaço" (apresentação contida na segunda edição do DOBRABIL, de 2001), a principal justificativa por trás da composição do JD foi o tempo e o momento em que o autor se encontrava. Como bibliotecário do Banco do Brasil, um apaixonado por livros e que estava perdendo a visão, leitor voraz de clássicos transgressores e participante ativo de grupos de discussão da causa gay, ter em mãos uma máquina de escrever e reflexos múltiplos de uma explosão de 
produções artísticas oriundas da ditadura militar, uma produção carregada de significantes e significados aconteceu naturalmente. O DOBRABIL foi o gatilho para Mattoso armazenar na escrita suas leituras feitas, já que sabia que a visão Ihe privaria um dia de retorná-las.

A escolha de um texto em formato de jornal permitiu ao autor resultados bem interessantes, com recortes de temas, autores e citações. A escrita apócrifa, de apropriação e "plágio", conduz cada página do folhetim, e a quebra de autoria confunde o leitor, que não sabe se aquilo que está lendo é realmente daquele cujo nome assina. O JD traz poemas, citações, cartas de leitores, com inscrições ora duvidosas ora paródicas, em que anagramas e trocadilhos fomentam o corpo editorial. As intervenções feitas pelo autor em textos consagrados, como de Manuel Bandeira e Garcia Lorca, também compõe a irreverência do folhetim, que descontrói o espaço poético pelo cômico, não desrespeitando literatos, mas consagrando-os ao citá-los.

Ironicamente, a figura do Jornal do Brasil vai sendo sutilmente deflagrada no DOBRABIL por nomes conhecidos do público - muitos desses, colaboradores do jornal carioca em algum momento, como é o caso de Bandeira, que, em meados de 1950, publicou "Poesia concreta" e falou de estilo e vanguarda no campo poético (CAMPOS, 2013, p.110). 


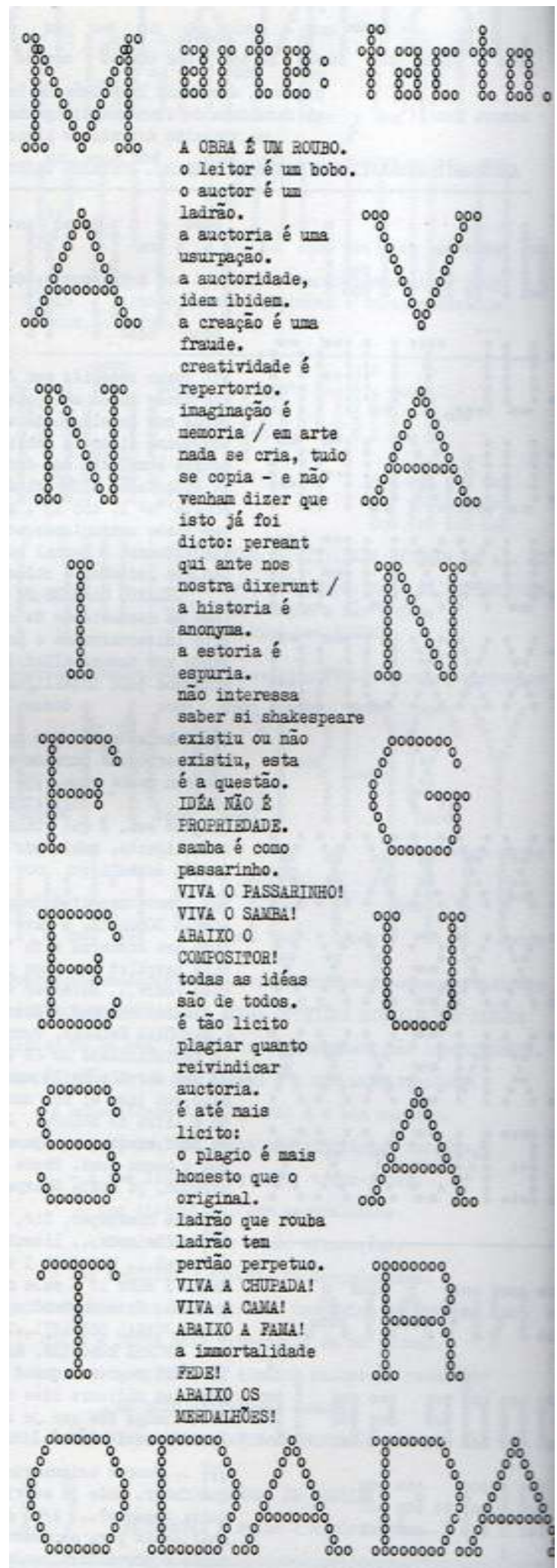

Figura 14. "Manifesto da Vanguarda”, JD, Glauco Mattoso, 2001.

O que Mattoso chama de "IV Manifesto da Vanguarda" (fig. 14) - ou outra possível interpretação: "Manifesto Vanguardada", em trocadilho com o Manifesto Dadá - é, sarcasticamente, uma crítica ao academicismo por trás da 
criação literária, em que o crítico exerce o papel de julgador da obra. Ao chamar o leitor de bobo, Mattoso rompe completamente com a ideia de pacto entre leitor e obra (LEJEUNE, 2014), em que o nome do autor e referências do eu são o maior indicador de origem e originalidade. A quebra de autoria é também um desestabilizante quando se pensa na relação entre criador e obra. Romper com as amarras criadas entre a literatura e o sagrado da originalidade e do cânone é ironizar um espaço, ainda hoje, rígido, cujo invólucro maior é o do ego por trás do grande nome que assina o texto. Na última página do JD, edição fac-similar, Mattoso constrói um índice onomástico, orientando o leitor aos conformes críveis de sua criação e situação. Uma ironia, pensamos nós.

Ainda sobre o manifesto, a palavra imortalidade, trazida ao final, ecoa longe e traz consigo o contexto da eternidade dada a uns poucos escolhidos, para compor uma academia nacional de letras. Mais do que isso, ela dialoga com a eternidade dada aos considerados grandes escritores e imortais perante a "grande literatura" e seus críticos. Os clássicos são, neste caso, uma construção de um ponto de vista, em que o discurso menor do leitor comum (ou não consagrado) fica abafado pelo poder da conceitualização e crítica dos que trazem consigo o peso da academia.

Mattoso fala do JD como uma elaboração despretensiosa, ignorando veleidades, na época, e reconhecimento: "Quando resolvi fazer poesia, em 74, não ambicionei preencher lacuna. Queria apenas brincar com alguns ingredientes da minha formação intelectual" (2011, sem indicativo de página). Ele queria escrever. Ele queria ocupar o espaço da folha com a explosão causada pela escrita das palavras. Nisso, a máquina de escrever foi determinante. $\mathrm{O}$ efeito estético visual produzido pela escrita datilografada em uma Olivetti é fruto de uma relação obsessiva com as palavras, em que a ocupação do espaço da folha em branco era uma necessidade absoluta. Essa escolha de Mattoso foi crucial e reveladora do magnífico resultado visual com a letra "o" minúscula, conforme pode ser observado nas imagens a seguir (fig. 15 e 16). 


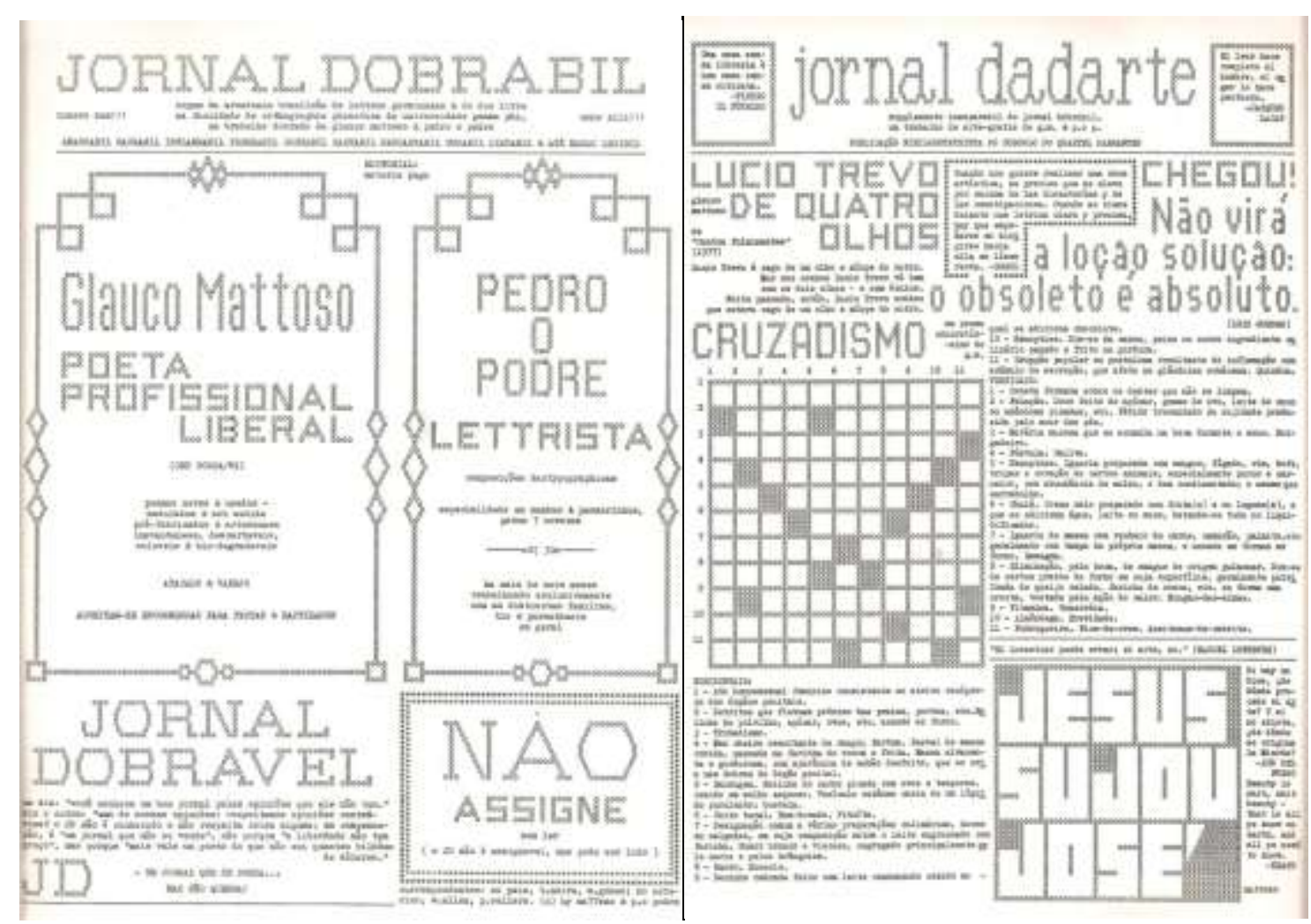

Figuras 15 e 16 . Página do Dobrabil e Jornal Dadarte (MATTOSO, 2001)

O Jornal Dadarte foi também um complemento do JORNAL DOBRABIL, e vinha no verso do folhetim. A temática de ambos variava entre a crítica à arte, ao academicismo, ao cânone literário e à escrita formal, até à brincadeira com as formas de divulgação e propagação de trabalhos artísticos e literários, durante o regime militar. Ademais, a sexualidade foi um elemento chave de discussão. Mattoso fez uma espécie de jornal literário mimeografado, misturado com arte postal, intervenção e recorte-colagem, bem como folhetim homoerótico sadomasoquista. Os adjetivos são múltiplos. As origens também. Manifestação artística de difícil definição, o JD foi uma forma que o autor encontrou de falar declaradamente do não dito, desconstruindo a ideia de elaboração descompromissada e singela. $\mathrm{O}$ acaso dadaísta se fez concreto na dinâmica do texto e na brincadeira com as palavras, embora o discurso se propusesse fortemente conceitual.

Dactylogrammas é o nome dado à escrita do JD. Quem cunha esta definição é um cânone nacional, da poesia concreta, Augusto de Campus. Com uma mistura de recorte literário e escrita de banheiro, os dactylogrammas traduzem a transgressão de linguagem feita por Mattoso e dão início a um 
projeto, hoje consolidado, de mesclar uma escrita chula com a linguagem formal anterior ao acordo ortográfico de $1945^{28}$.

O paradoxo do erudito com o popular é também o que mantém esteticamente o JD. O diálogo com outras épocas, publicações, autores e manifestações corroboram para a composição daquilo que se entende por divulgação e publicação jornalística. Nota-se que o autor fez um apanhado, um emaranhado, um caleidoscópio, como diz Susana Souto ${ }^{29}$, em que as leituras feitas são reverberadas na escrita explosiva do jornal.

Destaques no folhetim, manifestos são escritos e parodiados por Mattoso como grito à liberdade de escrita e quebra de hegemonia literária. Como negação de estéticas, satiriza a função fática do discurso de manifesto e exige, pela irreverência, possibilidades e realizações semânticas sem fixar-se a ideais estéticos. A exploração da escrita por manifestos é referência e diálogo com os textos modernistas, publicados na Revista de Antropofagia e Klaxon, bem como o Manifesto Dadá (1967), escrito por Tristan Tzara. Abaixo, uma das páginas do Jornal Dadarte, com destaque para a construção estética tipográfica e menção à Revista de Antropofagia (fig.17).

\footnotetext{
${ }^{28}$ Glauco Mattoso está em desacordo com a escrita vigente. Mantém o blog ETYMOGRAPHIA, em que arquiva seus "commentarios sobre o systema etymologico que elle adopta e diffunde em chronicas publicadas desde 2009 e em seu DICCIONARIO ORTHOGRAPHICO PHONETICO/ETYMOLOGICO".

Disponível em: < http://correctororthographico.blogspot.com.br/2013/05/marco2009-oorphanato-inglez-e-o-asylo.html>

29 Pesquisadora de Glauco Mattoso. Professora da Universidade Federal de Alagoas. Defendeu a tese $O$ caleidoscópio Glauco Mattoso em 2008, explorando a poesia do autor que marca o início da fase cega.
} 


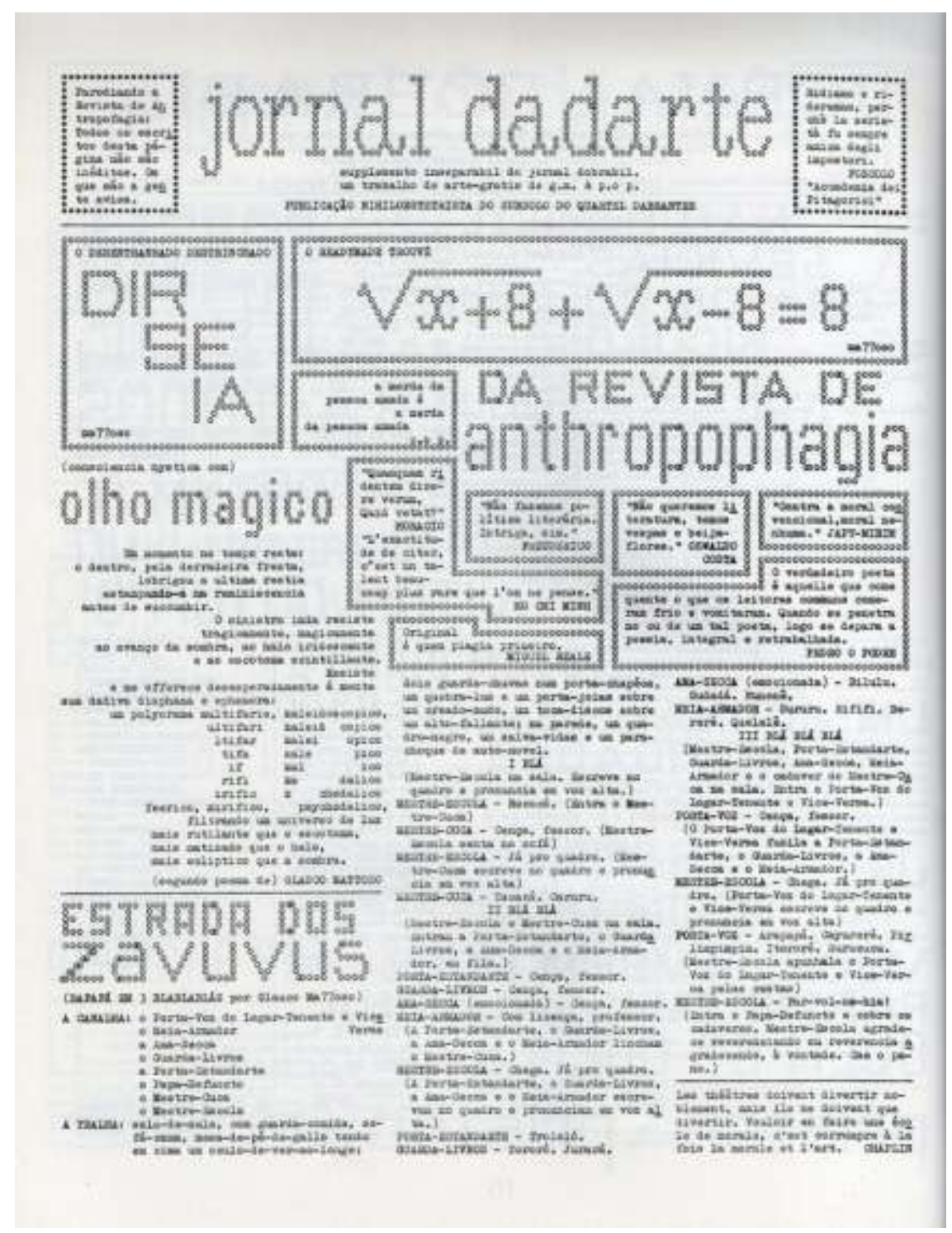

Figura 17 - Jornal Dadarte, JD, Glauco Mattoso, 2001.

Vale ressaltar que cada edição do JD tinha apenas uma folha, com duas páginas. Era um jornal dobrável, outra referência ao nome, que indica despretensiosidade do folhetim, podendo ser dobrado, amassado ou jogado fora. A primeira página apresentava o nome e as informações que compunham o corpo editorial do jornal, bem como a forma como este foi produzido: "marretado numa olivetti" e "xerecado numa xerox". O verso era destinado a dois espaços: Jornal Dadarte e Galeria Alegria - esta, com uma escrita visual interessante, cuja aletra "l" aparece grafada como "y" de cabeça para baixo, formando, também, a palavra "gay" (Fig. 18). 


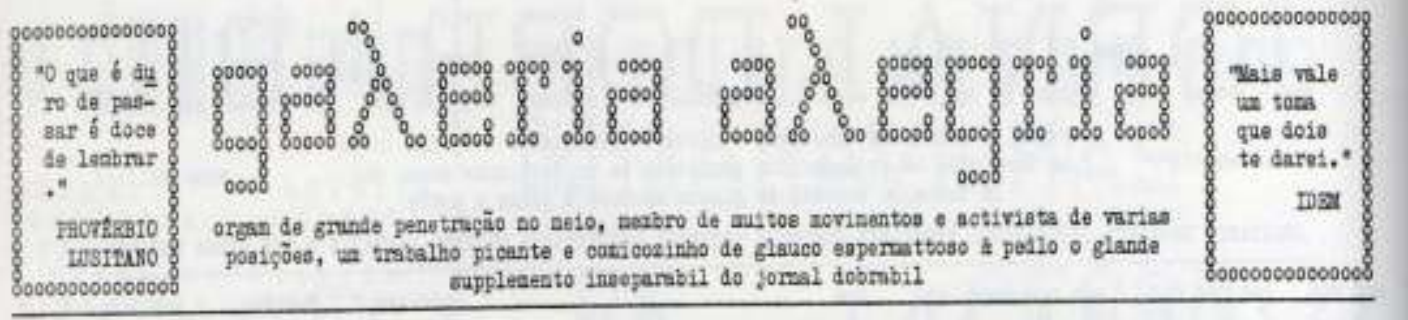

Figura 18 - Galeria Alegria, JD, Glauco Mattoso, 2001.

Em 2002, Mattoso publica livro homônimo, Galería Alegría (fig. 19), em espanhol. O livro é uma homenagem à memória de Néstor Perlongher, antropólogo argentino, que posfaciou a primeira edição do Manual do podólatra amador, publicado em 1986.

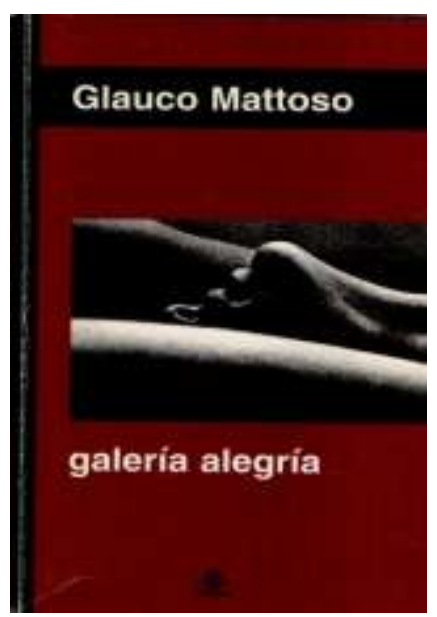

Figura 19 . Capa do livro Galería Alegría, de Glauco Mattoso (1986)

Mattoso não nega suas origens e expõe em seus textos, desde 0 DOBRABIL ao último soneto, um diálogo de enunciados latente, em que sua formação de leitor torna-se crucial para a formação do autor, conforme aponta Souto:

Metamorfoseada em sua escrita, a leitura é prática criadora para Glauco Mattoso. Mas, o que se cria? Criam-se outros modos de organizar listas e repertórios, modos que embaralham os critérios existentes, que desorganizam a biblioteca. Não há substituição de uma ordem por outra, mas sim o deslocamento da ideia de ordem, com a explicitação não só das suas referências como também do arbítrio de qualquer organização estável. Faz-se o elogio da instabilidade de qualquer critério ordenador, valorativo... (SOUTO, 2008, p.34) 
Como resultado dessa relação dialógica com o Modernismo brasileiro, Mattoso cria uma espécie de novo conceito de escrita literária a partir da antropofagia oswaldiana. $\mathrm{O}$ termo coprofagia ganha vida e significado a partir da elaboração do DOBRABIL e passa a ser defendido pelo autor em outros textos, publicados posteriormente.

Trazer para a literatura os grafitos de banheiro e criar para essa escrita um conceito, cujo significado é uma apropriação do termo biológico que significa "comer fezes" é uma ousadia. Mattoso coloca frases sem dono, escritas por trás das portas de banheiros públicos, cuja testemunha principal é o vaso sanitário e os dejetos nele contido, no território das Letras, espaço em que o legítimo parte da autoria e da escrita poética e, sobretudo, meticulosa.

Aqui, alguns conceitos são elementos-chave para compreensão da estética glaucomattosiana. Coprofagia é destaque por trazer a ideia de uma escrita que se aproveita daquilo que é excluído semanticamente, num emaranhado intertextual. Nota-se que, desde o princípio, Mattoso escreve coprofagicamente, na medida em que recolhe os dejetos literários colocados no limbo entre o que pode ou não ser dito. A associação da escatologia com a erudição literária promove um estranhamento no leitor e permite variados efeitos estéticos, experimentados pelo contato com poemas de teor irreverente. 


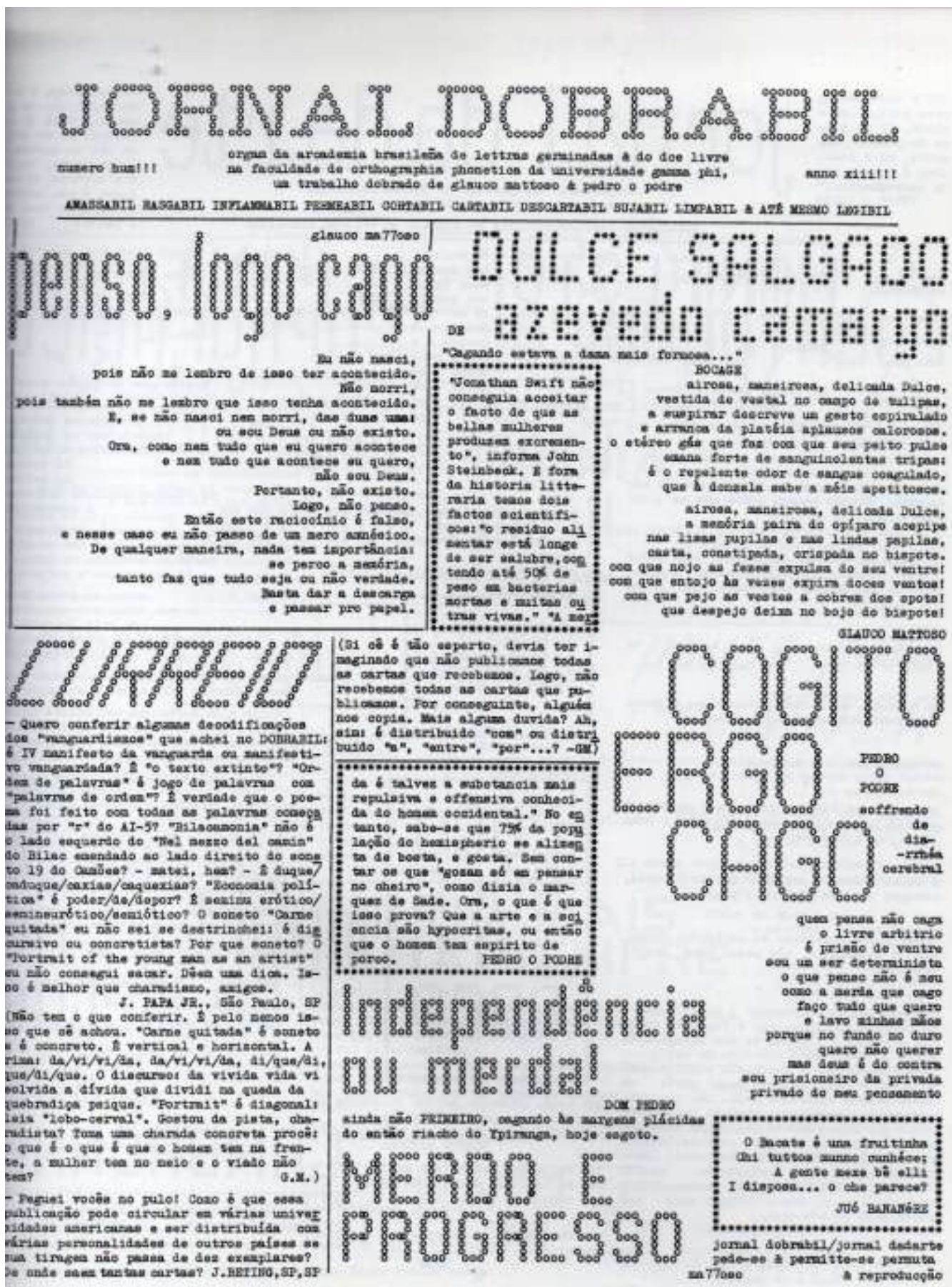

11

Figura 20. Página do JD, Glauco Mattoso, 2001.

O paradoxo trazido no poema "Penso, logo cago" (fig. 20) aborda a existência como relação direta entre os elementos naturais do humano em contraposição com a criação divina. O embate entre aquilo que é excremento do corpo, negado enquanto discurso, e a razão e consciência de si, tenta anular a incompatibilidade entre corpo e mente, reconfigurando o indivíduo 
enquanto ser que, ao passo que pensa, também sente. Defecar, pensar, refletir, esquecer ou ter a certeza de, são condições e propriedades humanas, que indicam um movimento existencial de compreensão de si mesmo no mundo. A partir de uma piada, encerrada com a frase "Basta dar a descarga e passar o papel", Mattoso coloca no plano mais natural possível as angústias da vida enquanto consciência de si. A ironia é fortalecida quando se analisa por inteiro o folhetim e nota que há, em outros textos, reflexões que mantêm esse paradoxo entre o existir, o pensar e o "cagar". Três ações propriamente humanas, porém e, ironicamente, apenas uma delas negada enquanto ligada ao baixo-ventre e anulada enquanto discurso.

Se por um lado a escrita glaucomattosiana desestabiliza quanto à escolha do pastiche e da satirização com o jornalismo e a literatura, ela também inova do ponto de vista que converte o que é abjeto ao contexto erudito e vice-versa. É um trabalho minucioso, em que sua análise aprofundada requereria de seu investigador um trabalho de dedicação em torno dos elementos intertextuais que a compõem. Trabalho este quase impossível, quando se quer, de fato, catalogar e definir as origens do que foi recortado, bem como quem são esses nomes e heterônimos que fazem parte do corpo editorial do jornal intertextual.

Mesmo assim, faz-se necessário antecipar uma discussão heteronímica: Pedro o Podre. Segundo Glauco Mattoso, em entrevista ${ }^{30}$ concedida a nós, Pedro o Podre é seu lado mais dionisíaco, satírico e, literalmente, podre. A brincadeira com consciências literárias heteronímicas começa com 0 DOBRABIL e se estende por toda a carreira literária de Mattoso. Mas Pedro o Podre ganha definição especial. Por ser mais cru e zombeteiro, no JD, Pedro ganha as falas mais condizentes com sua personalidade criada. A característica de transgressão dada a Mattoso é claramente consolidada na escrita de Pedro o Podre, bem como as variações de seu nome: Pedlo o Glande, Petrus Putris e por aí vai...

"O verdadeiro poeta é aquelle que come quente o que os leitores comuns comem frio e vomitaram. Quando se penetra no cu de um tal poeta, logo se depara a poesia, integral e retrabalhada.", diz Pedro o Podre em uma

\footnotetext{
${ }^{30}$ Entrevista realizada em maio de 2012, publicada na revista Uniletras, disponível em: < http://www.revistas2.uepg.br/index.php/uniletras/article/view/6733>
} 
das publicações do Jornal Dadarte. A reflexão sobre a criação poética feita a partir da associação com a ação de defecar põe a poesia no nível do mais perecível e degradável do homem. A poesia nasce de dentro para fora, mas é reflexo do que foi aglutinado, de saberes, intertextos e sensações, imediatas ou armazenados na memória, expressadas pela palavra. Ela é antropofágica por direito. O mesmo movimento é feito na alimentação: uma aglutinação de elementos externos e, posteriormente, uma excreção daquilo que o corpo precisa expulsar. Metaforicamente, Pedro deixa claro que: "poetar é cagar".

Revista Dedo Mingo

A Revista Dedo Mingo (fig. 21 e 22) foi o principal suplemento do JORNAL DOBRABIL, tornando-se uma extensão da publicação anarcopoética e solidificando a escrita por meio dos dactylogrammas coprofágicos glaucomattosianos.

Mattoso publicou duas revistas apenas e o projeto parou por aí. Obviamente o leitor da época já sabia da associação com o suplemento do Jornal do Brasil, a Revista Domingo, que nasceu pouco antes do JD de Mattoso, em 1976. 


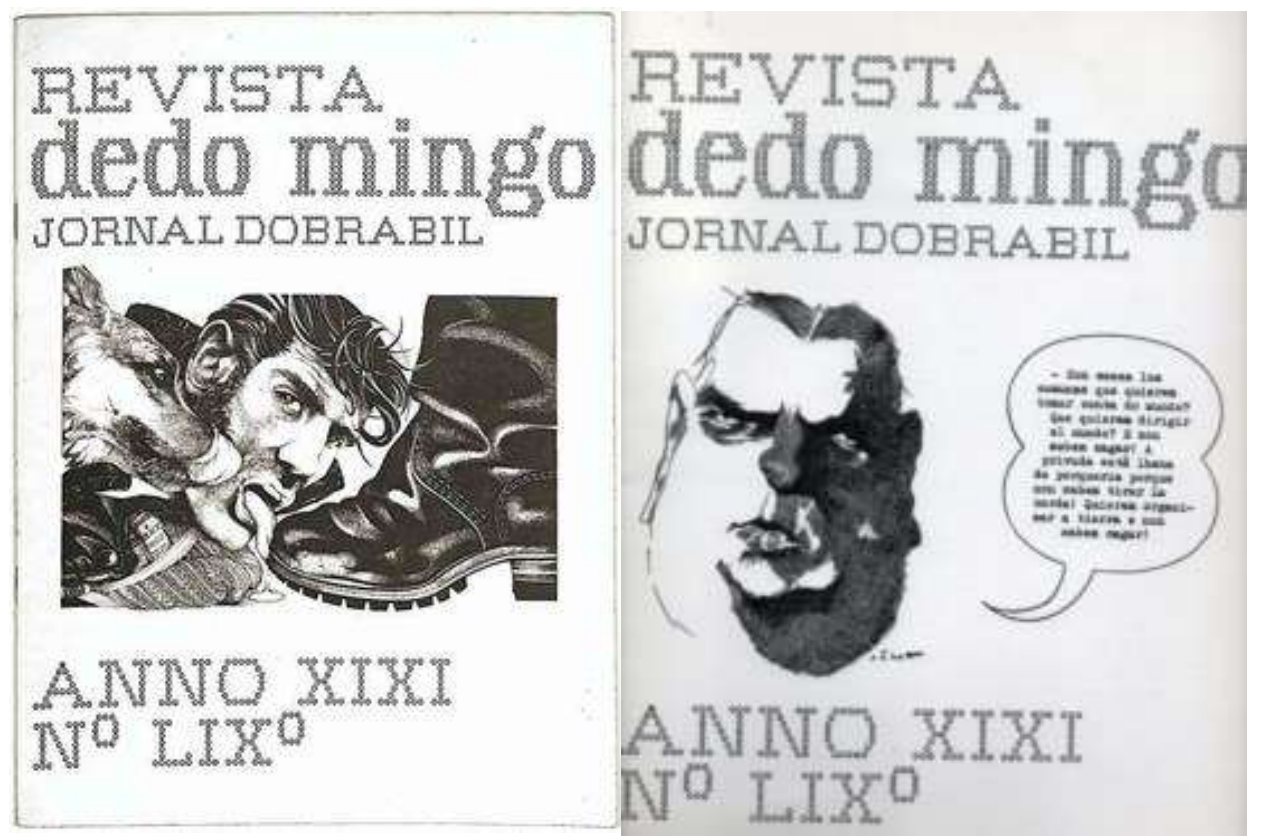

Figuras 21 e 22 - Revista Dedo Mingo, suplemento do Jornal Dobrabil , Glauco Mattoso, 1982.

As imagens de capa, assim como as escolhidas para o JORNAL DOBRABIL e outras obras do autor, fazem parte de um banco de ilustrações "pirateadas" por Mattoso em uma viagem aos EUA.

A podolatria, já reverberada nas páginas do DOBRABIL, também ganha destaque em uma das capas. Características sadomasoquistas compõem o arsenal poético da revista e a estética datilografada se mantém, misturada à característica de recorte e colagem. O teor homoerótico também é preservado e em uma das edições, em especial, há um espaço destinado a textos jornalísticos sobre a recepção do JORNAL DOBRABIL pela imprensa, solidificando a persona Glauco Mattoso enquanto poeta satírico.

Para esta pesquisa, esses dados são fundamentais, haja vista que, para se compreender o processo de construção heteronímica, é imprescindível passar pelo momento em que Mattoso ganha vida e forma fora do espaço interno da obra, sendo conhecido e reconhecido como o herdeiro de Gregório de Matos e Bocage, ganhando rótulo de maldito e fescenino, principalmente a partir da publicação do JD. 
A Glaucomix

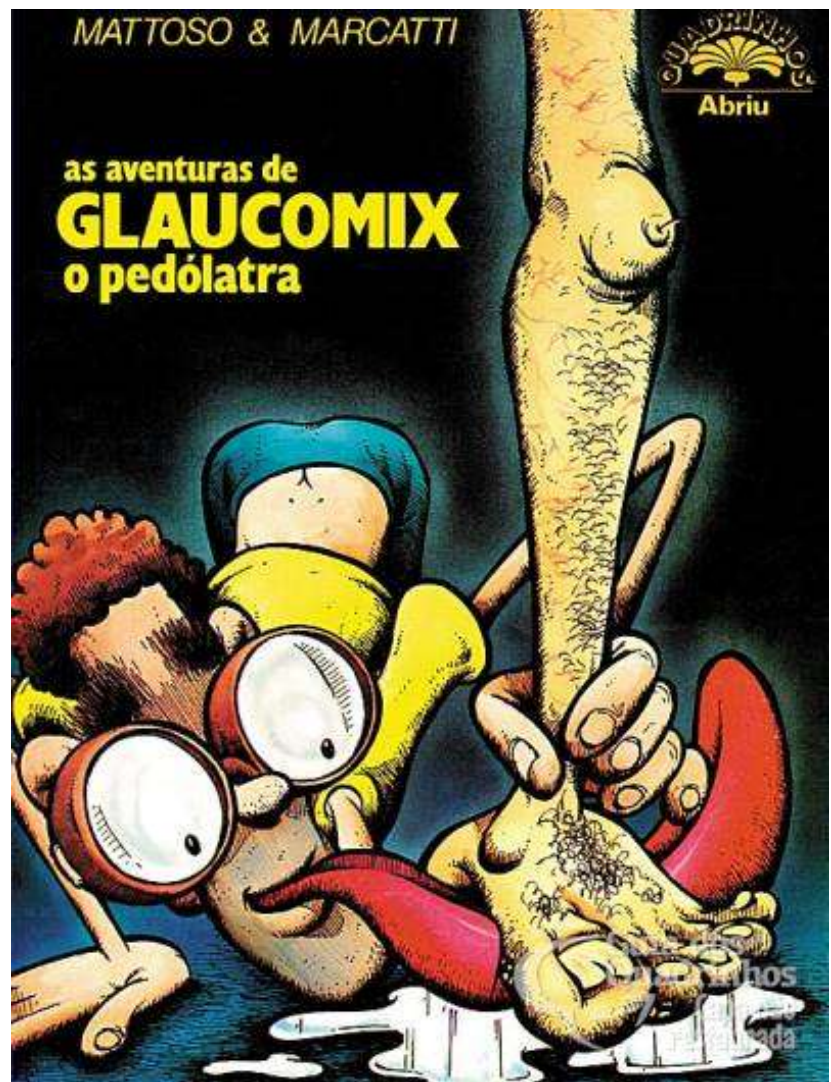

Figura 23 - Capa da HQ Glaucomix, Mattoso e Marcatti, 1990.

A revista em quadrinhos Glaucomix merece ser trazida aqui, por ser proveniente da publicação do Manual do pedólatra amador, em 1986. O quadrinista Marcatti e Glauco Mattoso decidem fazer parceria numa releitura do texto de caráter autoficcional de GM, permitindo, quadro a quadro, a representação imagética de partes narradas no romance podólatra do poeta. 


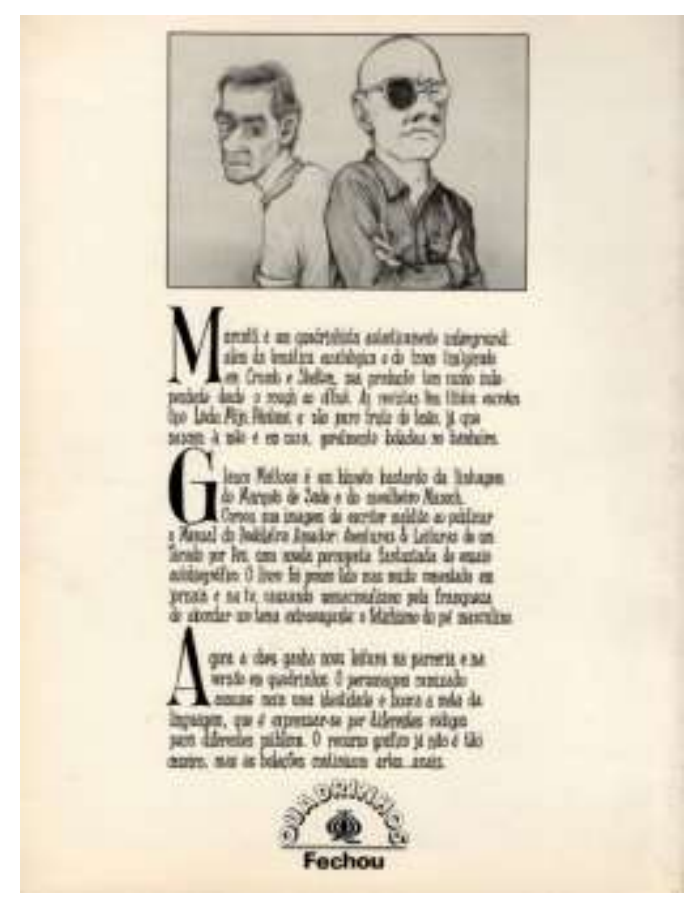

Figura 24. Verso da revista Glaucomix, Glauco Mattoso e Marcatti (1990)

Trazer Glaucomix antes de falar diretamente do Manual parece um pouco precipitado. Aqui, esta atitude foi intencional. A HQ, apesar de ser uma releitura do Manual, tem sua própria poética, tendo em vista que, o que ganha destaque no texto é a personificação do vírus HIV, como um vilão que persegue Glauquinho (fig. 25), personagem principal da trama, com a intenção de infectá-lo. Este, por sua vez, torna-se cada vez mais imune, a partir do momento em que opta por um sexo sem usar, de fato, as genitálias, mas, sim, o pé: sua principal zona erógena. 


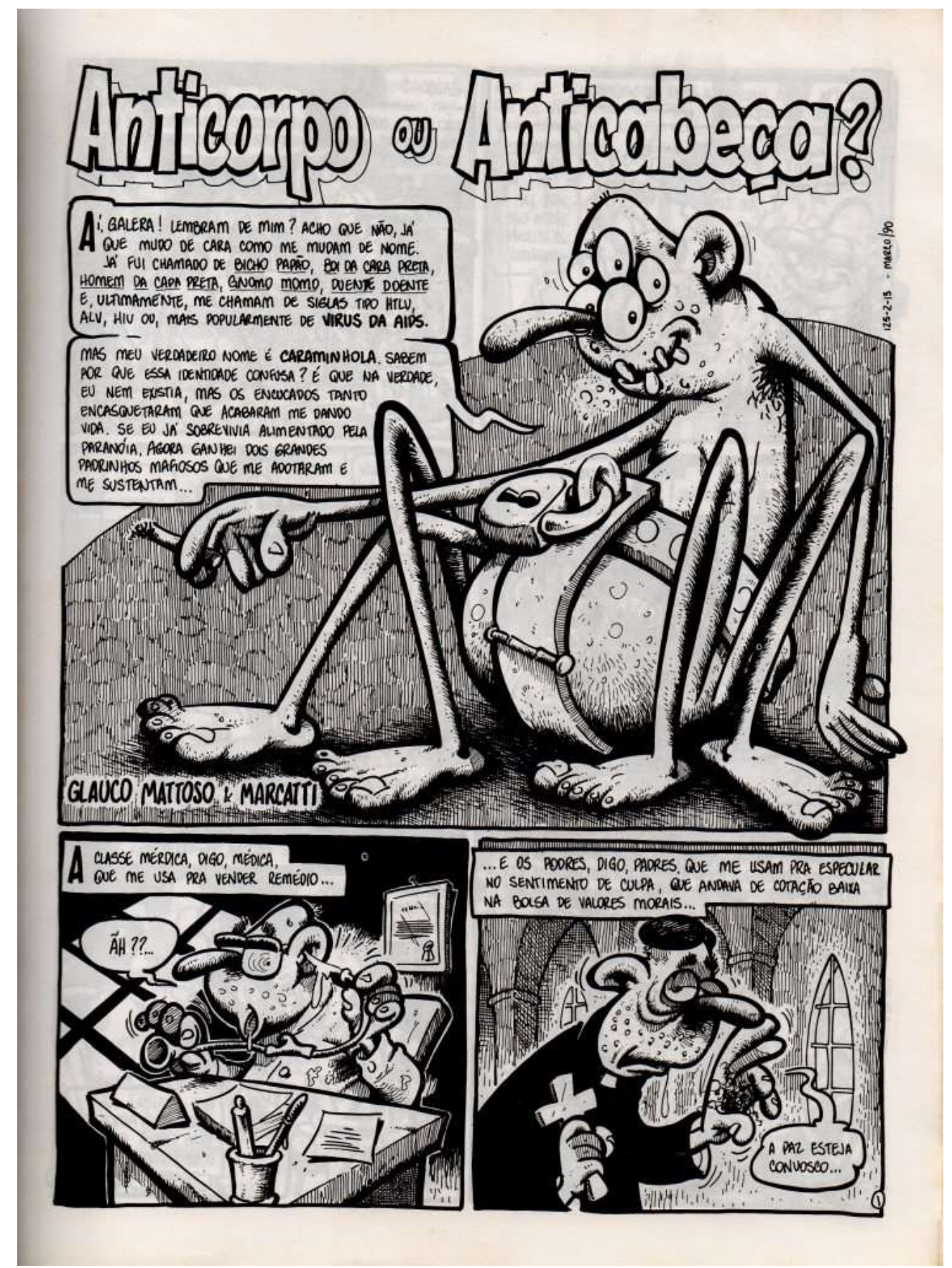

Figura 25. Página da HQ Glaucomix. Destaque para a personificação da AIDS. MATTOSO e MARCATTI, 1990.

O elemento norteador que conduz o quadrinho é metaforizado pela figura redentora do pé. Mattoso promove um novo significado a esta parte do corpo, considerando-a digna de prazer, principalmente quando ligada a um cheiro característico de chulé e denunciador de má higiene.

Essas escolhas, trazidas a partir do traço de Marcatti, solidificam a imagem do pé como um forte ponto condutor da estética glaucomattosiana, 
construindo no imaginário do leitor o espaço que o pé ocupa na vida do escritor, dentro e fora da literatura. Essas associações, interna e externa, são possíveis porque o autor tenta conduzir o leitor, a ponto de promover uma interpretação entre autor e obra, ficção e realidade.

As discussões acerca dessa relação entre o texto literário e elementos de credibilidade reforçam nossa tese de construção do eu a partir da arte, cuja intenção está em solucionar conflitos reais por meio da manifestação sensível de linguagens. Ao trazer para o plano da escrita angústias que são próprias da condição humana, Mattoso não só naturaliza discursos oprimidos, como também dialoga com um espaço que se propõe sagrado, que é o do autor e da literatura. 


\title{
2.1 Transitando pelo calvário dos carecas
}

\begin{abstract}
"A boca do calouro serve para, alem do mais, tirar do veterano o tennis, como um cão. Trabalho insano, si um nó seu dente nunca desatara!"
\end{abstract}

MATTOSO, 2011

A escrita em prosa de Glauco Mattoso merece ser trazida pontualmente, a fim de demarcar seu envolvimento com o contexto da repressão, bem como representar sua fase visual de produção. $O$ escritor, que ganhou notoriedade pela quantidade de sonetos publicados desde 1999, também é ensaísta e romancista, embora seja reconhecido mais pela poesia.

As obras do autor escritas em prosa mantêm algumas características que se destacam e se repetem em todas elas: a temática de tortura, 0 fetichismo e a transgressão. Entre romances e contos estão os títulos: $O$ manual do podólatra amador (1986/2006), A planta da donzela (2005), Contos hediondos (2008) e Tripé do tripúdio e outros contos hediondos (2011). Estes três últimos, apesar de comporem a escrita em prosa de Mattoso, não são analisados nesta tese, embora nosso interesse pelas narrativas do autor seja elementar para compreensão e noção de obra. Optamos por não ampliar nosso corpus porque essas três publicações, em específico, fazem parte da fase cega do autor, em que a relação com a escrita em prosa se modifica, acreditamos nós, e os sonetos ganham espaço e reverberação. Vale comentar que, em Tripé do tripúdio, Glauco Mattoso revisita sonetos e os reescreve em formato de contos. A planta da donzela, romance podólatra do autor, é, deliberadamente, uma paródia do livro A pata da Gazela, de José de Alencar, publicado em 1870 com pseudônimo Sênio.

Entre as publicações ensaísticas, três títulos interessantes: $O$ que é poesia Marginal (1981), O Calvário dos carecas - ensaio sobre o trote estudantil (1985) e O que é tortura (1986). Os dois últimos, fortes referências 
ao tema da tortura, deflagram a ousadia da exploração temática por um viés fetichista e irônico, escritos em um período de abertura política e explosão de publicações memorialísticas, veementemente contrárias à prática da tortura acerca da repressão durante o regime.

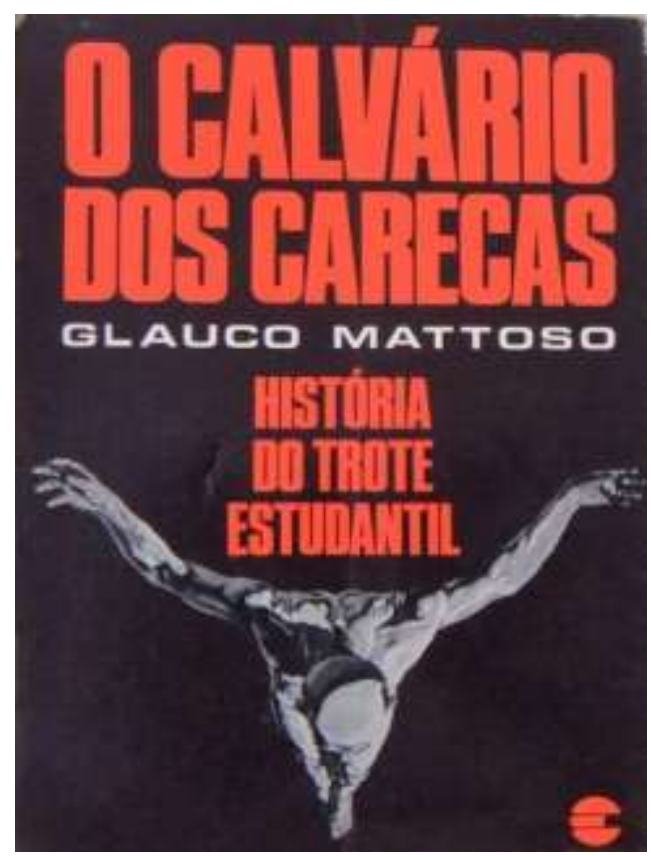

Fig. 26 - Capa do livro O calvário dos carecas, de Glauco Mattoso, 1985.

No Calvário dos carecas, em um movimento contrário ao do discurso delicado (quase nulo) sobre trote e tortura, Mattoso explora o tema de maneira oportunista, em que a pesquisa histórica serve de arsenal bibliográfico para construção fetichista do prazer pela dor.

E para mim, o que representa o trote, afinal? Se folclorista adora festas, antropólogo adora índio, psicólogo só pensa em significados, e militar tem fixação na disciplina, qual será o "vício", digamos, "intelectual" do Glauquinho? Fácil: minha "tara" é a própria, ou seja, a sacanagem. Para mim o conceito de trote se reduz de maneira assaz simplista. 0 trote, como o concebo (e não escapei do cacófato), não passa dum método de tortura. por vezes sutil, ora mais sofisticado, ora camuflado, e frequentemente escancarado. Mas nunca deixa de ser tortura. (MATTOSO, 1985, p. 118 - grifo nosso)

$\mathrm{Na}$ fronteira entre o ensaio e o texto histórico, o livro traz o contexto do trote estudantil, desde a Idade Média, e como a tortura integra o comportamento humano quando se há espaço para manipulação e opressão por parte de vozes legitimadas. Neste caso, a voz opressora é a do veterano; 
do indivíduo que se sente experiente e exige de seu calouro um ritual de passagem, tal qual o que ele vivenciou.

A palavra trote e suas coleguinhas calouro, bicho, louraça, etc. são mais ou menos novatas \& abstratas na língua (exceto o latiníssimo veterano), e não costumam comparecer assiduamente, com sua faceciosa faceta, em todos os dicionários vernáculos. (MATTOSO, 1985, p.11)

As variadas nomenclaturas acerca da prática e dos indivíduos que a elas são sujeitados corroboram para a metáfora da fraqueza e subserviência daquele que é troteado. Destaca-se a afeminação dada aos adjetivos, de maneira a conduzir à significação ao conceito misógino de fraqueza feminina. Mais do que isso, busca nas palavras uma forma de ferir moralmente, principalmente no que tange à homossexualidade, como pode ser observado nos chamamentos: bicha, ao invés de bicho, louraça, ao invés de calouro.

Segundo Mattoso, esse tipo de conduta sempre esteve presente, principalmente, nos espaços militares. O soldado é humilhado pelo general. $\mathrm{O}$ calouro pelo veterano; o carrasco... o algoz... Sobreposições de poderes são fatores determinantes para a prática da tortura (psicológica ou física) e com o trote não é diferente.

Mattoso aponta em diversas publicações que vão além desse livro, o desejo de se escrever uma enciclopédia da tortura e, especificamente, no Calvário dos carecas, ele afirma dar o pontapé inicial nesse tipo de pesquisa, até então inédita no Brasil. A capa do livro, um indivíduo careca e crucificado, representa uma contraleitura religiosa, remetendo-se a dois elementos pontuais, como crucificação e nudez, simbolizando a subserviência e entrega referência notória com o maior símbolo cristão.

A relação do autor com o trote é descrita, no Manual do podólatra amador, como um desejo latente de humilhação e submissão. Enquanto calouro, Mattoso deseja na pele sentir a opressão daqueles que se sentem acima dele. Essa imagem trazida no romance e discutida no Calvário dos carecas de forma pontual e com dados históricos, revela o quanto o indivíduo se sente seduzido pelo processo ritualístico do trote, tendo em vista que esta afirmação o colocará dentro de um espaço legitimado, cuja sensação é de 
conquista, de vitória, e, claro, de poder - permitindo, futuramente, exercer esse poder sobre o próximo ingressante. Por ser uma prática medieval, o trote só reforça como a identidade do indivíduo pode estar ligada à aceitação social do grupo o qual ele está inserido. Para Mattoso,

\begin{abstract}
Não é preciso aduzir novos exemplos para patentear aquilo que já estava inerente ao conceito do trote, desde o estrangeiro e desde o passado. Existe um encadeamento de aspectos, que funciona como fórmula para equacionar a questão. Tais aspectos se traduzem pelos termos tradição/desforra, integração/degradação, descontração/sadismo. Os três numeradores representam a faceta pretextual \& justificativa, e estão presentes na letra dos regulamentos hipócritas, na palavra dos diretores \& reitores omissos, e principalmente na boca dos veteranos mais cruéis: estes, para todos os efeitos, sempre seguem a "tradição", visam promover a "integração" e apenas agem com "descontração". Os três denominadores representam o lado prático, a consequência dos fatos, e aparecem no texto da imprensa que se pretende livre \& veraz, nas declarações das autoridades policiais (quando interessa), e sobretudo na boca dos calouros mais sacrificados: estes, no frigir dos ovos, sempre servem de bode expiatório para a "desforra", são vítimas animalizadas da "degradação" e cobaias para o "sadismo". Em última análise, o que fica é o elementar antagonismo e seu círculo vicioso. As situações extremas se contrabalançam e os termos se casam logicamente: a tradição perpetuando a desforra, a integração permitindo a degradação e a descontração propiciando o sadismo. (MATTOSO, 1985, p.114)
\end{abstract}

Mattoso vai em busca de dados reais sobre casos de trotes em universidades brasileiras e descreve, na parte "Pesquisa de Campus", episódios com algumas das mais severas ações quanto à recepção de alunos aos seus ingressantes. Mais do que isso, o escritor depõe em favor de um tipo de discussão pouco salientada, haja vista que rompe com o politicamente correto e exige reflexões de seus leitores sobre questões que ainda estão no terreno da "brincadeira" e da "descontração", como no caso do bulliyng, ou, como na tortura, ainda no âmbito da negação - terrivelmente velada.

Glauco encerra o ensaio com o que ele chama de "epílogro", em que dialoga ironicamente com o leitor, afirmando sua intenção com a escrita do texto: mais do que levantamento histórico e reflexão sobre a prática da tortura, uma construção sádica.

É isso aí, bicho: eu só queria mesmo era curtir os lances de sadismo e pura pornografia e, pelo jeito, todo o arcabouço teórico-histórico 
teria servido de mera moldura pras cenas pitorescas \& picantes. (MATTOSO, 1985, p.119)

O trocadilho da palavra epílogo, que ganha força pelo prefixo "logro", permite uma variação de significados, mas que toma como destaque a ideia de gozo, de deleite. Enquanto epílogo faz uma digressão e uma justificativa do que foi dito, o logro aglutinado à palavra nos conduz à seguinte percepção: tudo o que o autor trouxe e discutiu sobre tortura nada mais é do que a necessidade particular do seu gozo. Para nós, não é sua particularidade, enquanto indivíduo, que se propõe em questão, mas sua coragem de assumir, por um discurso irônico revestido de tara, a força para falar da tortura em primeiro plano da criação.

\subsection{Publicando na Brasiliense}

A Editora Brasiliense tem história no país. Com 70 anos no mercado editorial, ela foi contrária ao o Regime Militar no Brasil. Desde seu início, suas publicações eram em favor da classe trabalhadora, ainda em meados da década de 1940. Segundo a pesquisadora Andréa Lemos (2014), autores com histórias ligadas ao movimento comunista e à militância tinham espaço na editora.

Glauco Mattoso foi um dos que publicou na Brasiliense, logo no período de abertura política, com dois temas latentes do contexto ditatorial: a marginalidade e a tortura.

A Coleção Primeiros Passos traz centenas de títulos introdutórios em assuntos diversos, da sociologia à filosofia, da arte à medicina. Glauco Mattoso fez parte desse arsenal com dois títulos publicados na década de 1980 e já mencionados aqui: O que é poesia Marginal (1981) e O que é tortura (1986). 


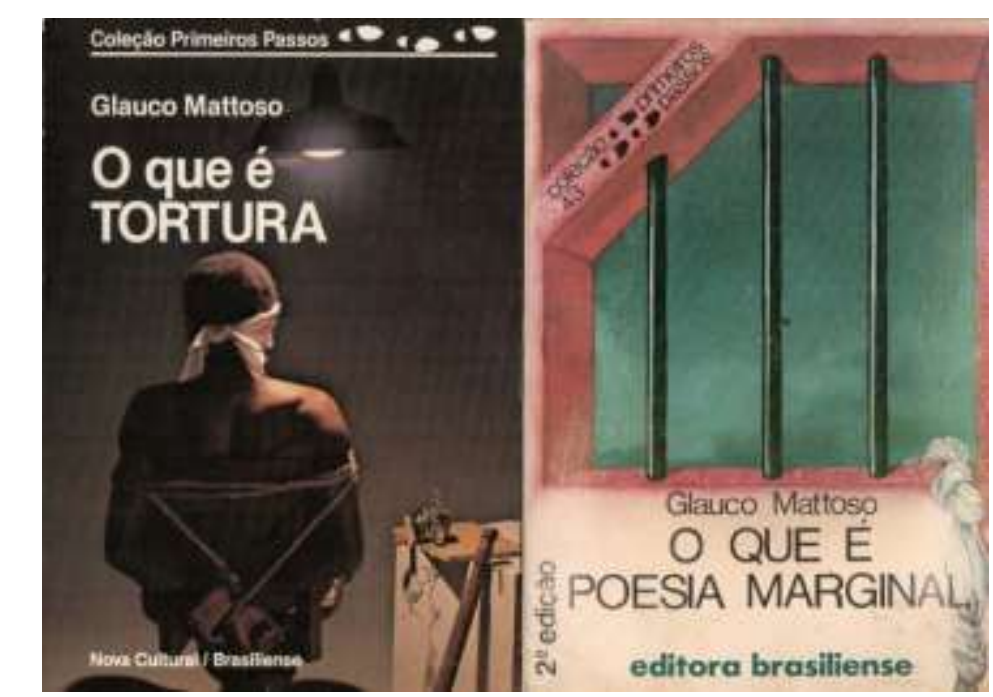

Figuras 27 e 28 - Capas dos livros, Glauco Mattoso - 1986, 1981.

Com uma linguagem acessível e sensível, próxima do coloquial, Mattoso discorre sobre esses dois temas de forma ensaística, com uma visão peculiar, não só de leitor crítico, mas de alguém que, de alguma forma, esteve próximo daquilo que descreveu.

Como poeta, foi um marginal entre os marginais. Trouxe as questões: "Como um poeta pode ser marginal? Existe uma poesia marginal? Marginal é o poeta ou a poesia?" (1982, p. 7) e, se não esclareceu muitas coisas, abriu espaço para reflexões e discussões acerca do tema.

A chamada escrita marginal ganha espaço logo após o tropicalismo e um pouco antes do Golpe. Com o início de uma ditadura e as restrições de diversas formas em torno das criações e divulgações de manifestações artísticas, o termo ganha significado mais forte, justamente por identificar um grupo que burlava as regras e os espaços de publicação de grande repercussão e notoriedade (MATTOSO, 1981). Por esta razão, muitos artistas começam a produzir artesanalmente seus trabalhos, conforme trouxemos anteriormente, e passaram a transitar pelas margens do espaço oficial, caracterizando assim uma estética do período, classificada como marginal.

Fenômeno coletivo da época da ditadura, Glauco Mattoso fala do surto da produção poética marginal e da explosão de revistas literárias produzidas independentemente. Nunca houve tanta produção literária circulando extraoficialmente em nosso país. O sufocamento do período despertou a 
criatividade e exigiu que as vozes dos artistas ecoassem em meio ao turbulento momento de repressão.

Mattoso traz discussões acerca do cânone literário, reforçando sua contrariedade quanto aos espaços sacralizados da produção artística. Também fala de subversão e palavra-de-ordem, bem como de relação com a produção artesanal e a despretensão da figura do poeta enquanto artista.

Dentro do conjunto da obra do autor, o livro colabora com a compreensão do espaço ocupado pelo escritor transgressor, que ultrapassa os limites da marginalidade, tendo em vista que Mattoso, mesmo publicando em espaços não legitimados pela crítica e se utilizando de uma linguagem contracultural, carrega consigo o peso do contexto literário a partir das leituras feitas, tornando-se, assim, um marginal erudito - usando aqui as palavras de Rosimere Meireles ${ }^{31}$, pesquisadora de GM.

A escrita marginal é um universo pelo qual Mattoso transita desde suas primeiras leituras às suas colaborações jornalísticas e sua poesia fescenina. $O$ escritor glaucomatoso insiste em trazer aspectos da sua condição humana como intencionais da sua poética, alardeando sua sexualidade e condição de cego em toda a escrita, sustentando um discurso pessoal e fetichista pelas amarras e paródias de textos clássicos consagrados.

O nascimento da poesia marginal, fragmentada e recheada de um vocabulário coloquial, miscigenada ao contexto da escrita proibida, tem também características da pichação, do ponto de vista de que, o anonimato, a crítica e a ruptura com sistemas formam elementos destaques na produção desse tipo de poesia: burlesca, invasiva, apropriadora. A recorrência de uma escrita denunciadora, em Mattoso, tem sua filiação na herança com a escrita do JD pela mistura de pastiche jornalístico, crônica, denúncia, humor e, principalmente, apropriação.

Já o livro O que é tortura (1986) nasce um ano após a abertura política e discorre sobre um tema ainda desconcertante do ponto de vista de quem viveu e sofreu tortura durante o regime militar.

Nesse livro, Mattoso convida o leitor a sentir "na pele" a tortura, de modo a pensar em quem viveu e como viveu esse tipo de situação. Ele alerta ao leitor

\footnotetext{
${ }^{31}$ Defendeu a dissertação "Glauco Mattoso: um marginal erudito” na UFES em 2002.
} 
dizendo que o ponto de vista dele é estético. Didaticamente, pergunta-nos se já fomos torturados ou se já torturamos, selando uma relação entre leitor e texto bem incômoda, porém fluida. Mattoso diz se distanciar da filosofia e assume que, para se compreender a tortura, é preciso se colocar no lugar de quem está sendo torturado, de modo a remeter-se, transportar-se para o cheiro do capuz que encobre o rosto ou nas cordas que amarram as mãos.

O autor também fala da nudez e de como esse é um elemento-chave para os torturadores, já que desestabiliza o indivíduo e the tira toda e qualquer dignidade possível. A tortura psicológica, outro fator discutido por Mattoso, é trazida como o primeiro passo da tortura, que já destitui de qualquer ação voluntária o indivíduo torturado.

As discussões empreendidas nos títulos de GM evocados até aqui comportam elementos intrínsecos ao fio epistemológico condutor da estética glaucomattosiana. Apresentar as publicações marginais, bem como seus ensaios, são uma forma de conduzir nossa leitura pelo contexto histórico, em que a tortura pode ser melhor percebida e identificada no Manual do podólatra amador, sem julgamentos morais ou através da tendência de um olhar politicamente correto acerca do tema.

No texto autoficcional, a tortura é elementar como forma representativa da transgressão dos valores humanos, principalmente quando destituída do invólucro semântico em torno de seu conceito e sua relação com a escolha e o prazer.

\subsection{0 pedólatra}

A pedolatria (ou podolatria) de Mattoso compõe a metáfora da sua relação com o pé, reverberada por toda a sua escrita, do JD aos sonetos, dos romances às crônicas, artigos e ensaios ${ }^{32}$. $E$, de fato, isso tem um peso

\footnotetext{
${ }^{32}$ Atualmente Glauco Mattoso escreve crônicas para o Blocos OnLine, site oficial da poeta Leila Míccolis. Sua coluna chama-se Ephemerdas e é mensalmente atualizada com crônicas permeadas aos sonetos anteriormente publicados. Disponível em: < http://www.blocosonline.com.br/literatura/prosa/colunistas/glauco/gm14emdiante/gmephem_ind ex.php>
} 
enorme para nossa pesquisa, pois compreender a estética glaucomattosiana é impossível sem trazer à tona seu fetiche por pés masculinos sujos, facilmente identificável em sua escrita e confirmado em nossas pesquisas sobre sua obra. Mas, para isso, será necessário mostrar ao leitor informações biográficas, a fim de se compreender por que esse gosto é elemento norteador que conduz a estética do escritor.

Enquanto deficiente visual, Mattoso faz dessa condição ponto dialógico com o fetiche por pés masculinos. Em sua escrita, deseja a dor, a degradação, a humilhação e pés sujos. Deseja estar por baixo, lamber e rastejar-se aos pés de seu carrasco. Traz como mote o comportamento masoquista do cego indefeso, que, por estar desprovido de um dos sentidos, deve ser currado. Para transgredir a degradação, deseja a curração. Extrapola os limites do politicamente correto e, literariamente, converte dor e sofrimento em prazer e gozo.

A podolatria, principalmente enquanto capacidade orgástica, é uma característica desconcertante quando se pensa em elementos éticos e não estéticos. Em diálogo com Foucault (2011), esse desejo expõe uma particularidade que não é consentida pelos dispositivos que controlam o sexo e a sexualidade. Unindo esse desejo ao rebaixamento do cego, humilhado e excluído, choca. Afinal, tem-se, como associação às limitações físicas de qualquer indivíduo, a percepção social comum e preconceituosa de um sujeito, não só limitado, como inferiorizado e necessitado de um "coitadismo", uma compaixão que menospreza a voz desse indivíduo, bem como suas habilidades e competências. Mattoso assume esse discurso e essa inferiorização, ironizando-as. E enquanto colocadas em cunho pessoal, elas são narradas e rimadas como forma de se compreender o que Mattoso chama de desumanismo, em que, por um prazer pessoal, priva-se o outro da possibilidade de ter prazer.

Hoje eu conceituei nos sonetos uma coisa que eu já praticava. O "desumanismo" é um neologismo como qualquer outro. Eu criei o "barroquismo", o "pornosianismo", o "desiluminismo", que são conceitos que envolvem a necessidade de encaixar o paradoxo, a contradição dentro dos termos. São termos que brincam, o que aprendi com o Millôr Fernandes. Uma das minhas fontes era o Augusto de Campos, na minha fase visual, naquela fase que eu misturava concretismo, mas pela vida inteira foi o Millôr Fernandes, 
porque era um cara que tinha uma visão filosófica fantástica e conseguia brincar com as palavras de uma forma admirável. Eu aprendi isso com ele, essa maneira de brincar, fazer paradoxos, cunhando palavras que são antíteses em si mesmas, que são contraditórias em si mesmas. E "desumanismo" é justamente você ser mais humanista através da exposição da realidade desumana. $\mathrm{E}$ quanto mais você escancara a realidade desumana, mais humanista você se revela. Você não vai ser humanista só falando de coisas virtuosas e santas, de bondade e de boas ações, senão você está fazendo um discurso de escoteiro para escoteiro, e não é assim que você vai combater a desumanidade, que você vai combater a barbárie. Eu sou adepto de você sempre escancarar as coisas, não deixar nada subentendido, nada eufemizado. Então é por aí. Agora... é lógico que eu sempre gosto de fazer as coisas com certo nível de ironia, de sarcasmo, nunca levando totalmente a sério, por isso eu gosto de brincar com essas palavras. Esse não é um conceito fechado, um conceito sisudo. Então, eu acho que o meu "desumanismo", a minha humilhação pessoal, pode parecer caricatural e exagerada como personagem literário, mas se você for comparar no contexto coletivo, global, ela não é tão grave. Tem casos muito mais violentos e grotescos que o meu. (MATTOSO, 2012) ${ }^{33}$

A tortura e o bullying fazem parte das falas do autor, dentro e fora da literatura. Estão por toda a obra de Mattoso e confundem o leitor quanto à veracidade dos episódios sofridos pelo eu-lírico, nos sonetos, e pelo autornarrador-personagem, nos contos e romances. Também transitam na conversão de uma ética em estética, ao passo que exige a anulação de uma moral externa que quer impossibilitar a fruição, haja vista que desestabiliza e choca.

O arsenal bibliográfico acumulado é fruto da sua relação com os livros e escolha de profissão. Na verdade, o que conduziu (ou o salvou, como ele mesmo diz em entrevistas e trechos do Manual) sua imersão nos livros foi justamente a terrível possibilidade de ficar cego, existente desde a infância e corroborada pelos inúmeros tratamentos e cirurgias sem efeito. Enquanto a pressão do olho aumentava, a bagagem literária dele também. Lia compulsivamente para depois compor compulsivamente.

Entre o período de poesia visual e os textos em prosa e a escrita compulsiva de sonetos houve uma lacuna de quase 10 anos. Um apagamento literário devido ao negro da cegueira enclausurou o escritor, que só voltara a compor tempos depois, quando conseguiu comprar um computador falante. Esse material foi fundamental para o retorno de Glauco Mattoso à escrita

\footnotetext{
${ }^{33}$ Disponível em: < http://www.revistas2.uepg.br/index.php/uniletras/article/view/6733>
} 
literária. Fruto do Prêmio Jabuti, famosa premiação literária nacional, GM é congratulado pela tradução de Fervor em Buenos Aires, de Jorge Luís Borges e volta ao espaço da literatura com uma tetralogia ${ }^{34}$ de sonetos, publicada entre 1999 e 2000.

Outro elemento condutor de sua escrita, já comentado aqui, é a homossexualidade, explorada por Mattoso de inúmeras formas no contexto literário. $O$ autor reforça essa identidade de acordo com a exploração do fetiche e da sua relação com seu companheiro de descendência japonesa, Akira Nishimura.

Mattoso foi citado por muitos, principalmente em temáticas fetichistas e sadomasoquistas. Também escreveu antologias com Antonio Vicente Seraphin Pietroforte $^{35}$ e Nilto Maciel ${ }^{36}$. Com Pietroforte, publicou Aos pés das Letras: Antologia podólatra da literatura brasileira (2010) e M(ai)s: Antologia sadomasoquista da Literatura Brasileira (2008) e com Maciel, Queda de Braço: Uma Antologia do Conto Marginal (1977).

Como poeta transgressor, já foi estudado por pesquisadores estadunidenses, como Steven Butterman ${ }^{37}$ e David William Foster ${ }^{38}$, embora ainda não tenha ganhado força expressiva nas pesquisas acadêmicas nacionais. Ainda com um número irrisório de teses e dissertações sobre o escritor, não há, até o momento, nenhum livro nacional sobre sua obra, desfavorecendo a formação de uma fortuna crítica.

Mattoso também se enveredou pelo terreno da música e criou um selo independente de gravação musical, $\mathrm{O}$ Rotten Records, lançando artistas alternativos e undergrounds da década de 1990. Ainda em diálogo com a música, produziu, em 2001, o Melopéia: sonetos musicados (fig. 29), em que artistas da música nacional cantaram seus sonetos.

\footnotetext{
${ }^{34}$ A tetralogia, defendida na tese de doutoramento da pesquisadora e professora Susana Souto, é composta pelos títulos: Centopéia: sonetos nojentos \& quejandos (1999); Geléia de rococó: sonetos barrocos (1999); Pauliceia llhada: sonetos tópicos (1999) e Panacéia: sonetos colaterais (2000).

${ }^{35}$ Professor e pesquisador da Universidade de São Paulo.

${ }^{36}$ Escritor e editor brasileiro (1945-2014).

${ }^{37}$ Butterman doutorou-se na Universidade de Miami, com um estudo sobre a anti-estética de Mattoso, posteriormente transformado em livro: Perversions on parade: Brazilian Literature of Transgression and Postmodern Anti-Aesthetics in Glauco Mattoso (2005)

${ }^{38}$ Foster escreveu um artigo sobre o Manual do podólatra amador no livro Cultural diversity in Latin American literature (1994).
} 


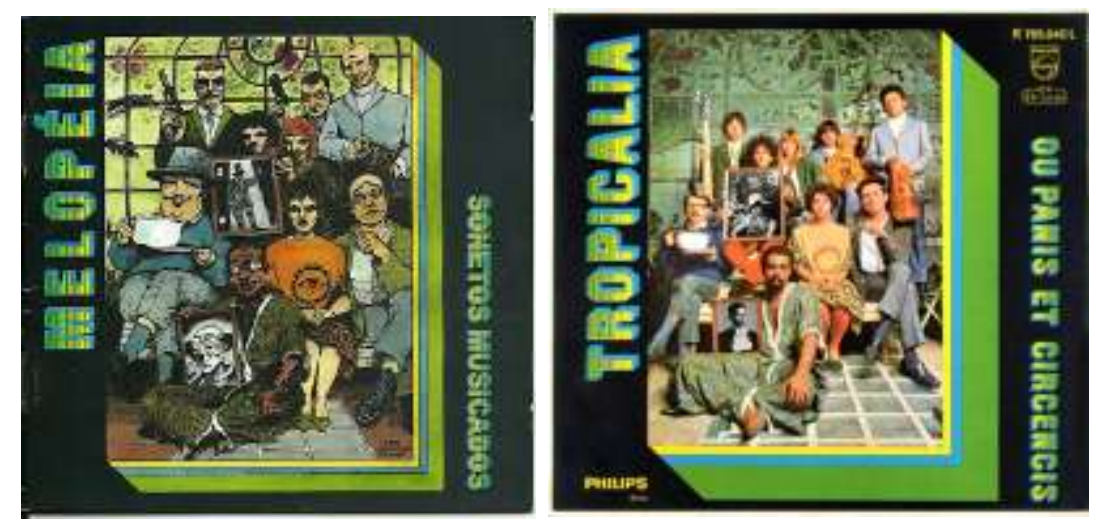

Figura 29 - Capa, feita por Lourenço Mutarelli, do CD Melopéia (2001), de Glauco Mattoso;

Figura 30 - Capa do disco Tropicalia, foto de Oliver Perroy, 1968

A irreverência da paródia contida na capa se expande às escolhas dos títulos de seus livros e das ilustrações escolhidas para compor seus textos. Os espaços percorridos por Mattoso são múltiplos. Inclusive, chegou a publicar, em 1995, um livro sobre os skinheads, intitulado: Skinhead - Letra por letra (fig. 31), escrito no momento tido como silêncio literário. O livro traz a reunião de algumas canções de skinheads, conhecidos no Brasil como "carecas".

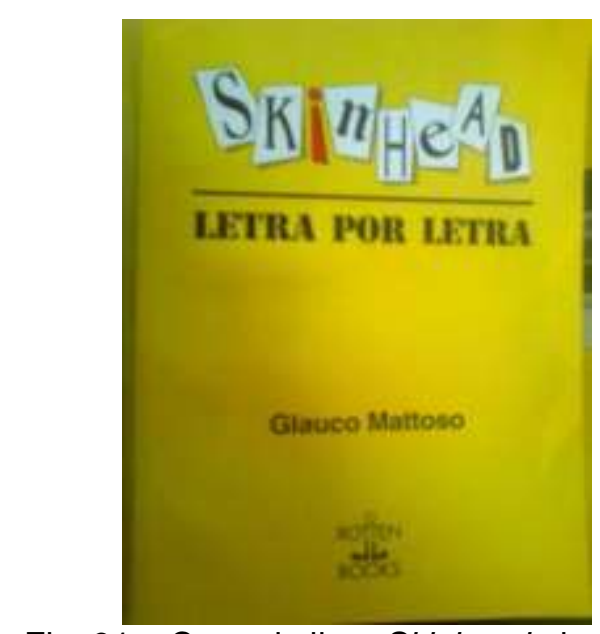

Fig. 31 - Capa do livro Skinhead, de GM, 1995

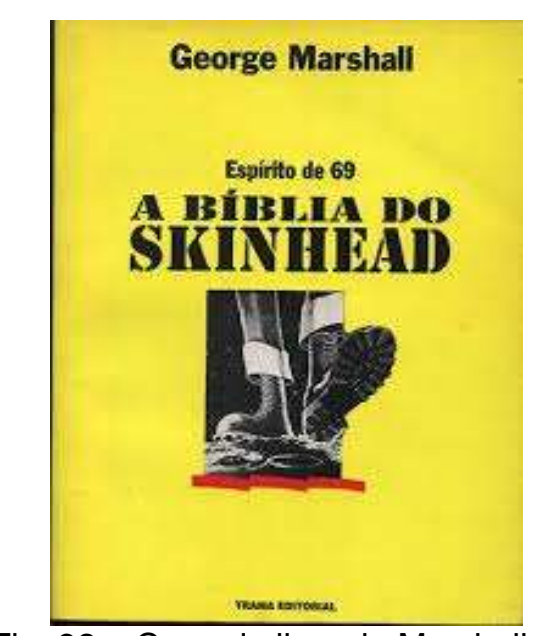

Fig. 32 - Capa do livro de Marshall, traduzido por GM, 1993

GM também traduziu a Bíblia do skinhead, de George Marshall, (escocês skinhead tradicional) em 1993. A música punk e o comportamento subversivo proveniente da cultura urbana intensificam as referências de Glauco Mattoso, verbalizadas na sua escrita. Outros elementos, que vão além da 
intertextualidade, da paródia e do pastiche, são as imagens trazidas por essas referências: como a "careca" dos skinheads, as roupas características e os coturnos militares, que fazem uma referência direta com as cenas criadas nas narrativas e nos sonetos de Mattoso, em que se coloca na posição de lamber botas e tem sobre seu rosto o "pisão" da sola suja. A violência representada pelos estereótipos do grupo de "carecas" também reforça os elementos estéticos criados por Mattoso, em que um se sobrepõe ao outro, em forma humilhação e degradação. Isso intensifica a pluralidade de linguagens transitadas pelo autor. Mattoso assume-se marginal, mas com uma erudição digna de cátedra acadêmica. É subversivo enquanto poeta, é glaucomatoso enquanto cego dotado de múltiplas visões e é podólatra enquanto escolha sólida e representativa, metaforizando relações de poder em suas mais plurais substâncias. 
Soneto incontinente [2.246]

Soneto é o mundo inteiro em pouco espaço, mas, para os mais lacônicos, prolixo.

O gosto é variado, e o metro, fixo, e amante deste oximoro me faço.

A prosa pesa, empilha um calhamaço. Concisas poesias são prefixo.

Somente no soneto gravo e mixo começo, meio e fim, no exato laço.

Qualquer história, fábula ou idéia comporta enunciado num soneto, da simples anedota a uma epopeia.

Apenas dois assuntos, eu prometo, não cabem no soneto: a diarréia e o pé, mas porque sobram, não por veto.

MATTOSO, 1999

Os principais estudos ${ }^{39}$ acadêmicos sobre Glauco Mattoso dissertam sobre seus sonetos ${ }^{40}$. De fato, quase toda sua obra é composta por poemas metrificados. Entretanto e já defendido aqui, optamos por trilhar um caminho diferente, concentrando nosso olhar na prosa como fio condutor da estética presente na obra glaucomattosiana.

Embora nossa escolha esteja clara, é necessário observar a dicotomia da escrita de Mattoso quando se propõe divida em duas fases e duas formas distintas.

Ao confrontarmos as escolhas estéticas glaucomattosianas entre prosa e poesia, apesar da imprecisão dessa dicotomia, principalmente em se tratando de literatura contemporânea, intencionamos mostrar como o próprio autor

\footnotetext{
${ }^{39}$ Teses e dissertações, com destaque para os estudos de Steven Butterman, Maria Aparecida Silva e Susana Souto, cujos textos estão especificados na bibliografia.

${ }^{40}$ Os sonetos de Glauco Mattoso não são o objeto central de análise desta tese, o que justifica a breve explanação, cuja intenção foi, apenas, a de apresentar ao leitor o Mattoso enquanto sonetista, na fase de escrita em que o próprio autor denomina como "cega".
} 
diferencia sua produção a partir da escolha textual, formando um divisor de águas entre o antes da cegueira e depois dela.

$\mathrm{Na}$ contemporaneidade, momento de aparente liberdade de criação literária plurilinguística, cujos espaços não são rígidos nem nítidos e a escrita permeia entre várias áreas do conhecimento e diferentes gêneros, formas e mídias, ter um poeta que retoma a escrita mnemônica do soneto é, de fato, paradoxal.

Antes de Glauco Mattoso, o último tratado de versificação publicado e estudado por poetas e acadêmicos foi o de Olavo Bilac (1865-1918), parnasiano nacionalista, cujas influências vinham de poetas românticos como Gonçalves Dias (1823-1864). Hoje, já esgotado na editora, o tratado de versificação atual é obra de Glauco Mattoso, contribuindo ao interesse de adeptos à escrita sonetista, bem como a conquista de um espaço atualmente esquecido pela poesia nacional. A primeira edição do tratado saiu online, em PDF, com o título $O$ sexo do verso - Machismo e Feminismo na regra da poesia $(2010)^{41}$. Na nota introdutória, Mattoso esclarece:

\begin{abstract}
Não se trata de procurar chifre em cabeça de cavalo, ou de égua. A versificação lusófona, quer na terminologia, quer na praxe, comporta dois pontos de vista que equivalem a um olhar masculino e outro feminino na direção do fazer poético. De um lado, as musas que inspiram o bardo, o vate, o menestrel ou o cantador, e as divas que Ihe declamam os poemas nos saraus e recitais; do outro lado, as poetisas que abrem mão do gênero frágil e querem ser "poetas", ainda que não se encontrem "bardas", "vatas", "menestrelas" ou "cantadoras" para representar a faceta fêmea do ofício lírico. No meio do tiroteio, em lugar do cego violeiro ou rabequista, este cego soneteiro e glosador, disposto a rastrear os passos do compasso métrico e a desmistificar o machismo e o feminismo subjacentes nos parâmetros da composição do poema. (MATTOSO, 2010, p.9)
\end{abstract}

O escritor começa a publicar seus sonetos ainda no JORNAL DOBRABIL. O primeiro observado no JD consta no segundo folhetim (ordem da organização fac-similar e não de distribuição), cuja referência direta é feita a Bilac e Camões, dois poetas significativos no processo de criação da poesia de Glauco Mattoso:

\title{
Bilacamonia
}

cheguei partiste

\footnotetext{
${ }^{41}$ Disponível em: http://www.elsonfroes.com.br/sexodoverso.pdf
} 


\author{
e triste descontente \\ tinhas a alma no céu eternamente \\ e a alma na terra sempre triste \\ e paramos de súbito onde subiste \\ da vida desta vida se consente \\ a tua mão amor ardente \\ tive da luz que viste \\ hoje pode merecer-te \\ nem o pranto que me ficou \\ nem mágoa sem remédio de perder-te \\ e eu solitário anos encurtou \\ vendo a ver-te \\ na extrema curva de meus olhos te levou
}

(MATTOSO, 2001 - sem indicativo de página)

Os recortes feitos para a elaboração do soneto acima dialogam com a forma estética da elaboração do JD, em que a colagem intertextual e apropriadora formulam um espaço onde o pastiche funciona excepcionalmente.

Já utilizamos em outros momentos o termo pastiche como característica da obra de Mattoso, principalmente enquanto estrutura do DOBRABIL. Ao trazermos o conceito de pastiche, tal qual de paródia (ambos ligados à intertextualidade), retornamos à Genette, em Palimpsestos (2006), quando fundamenta as práticas intertextuais como derivadas e dependentes umas das outras, misturadas pela relação de apropriação.

Como poeta, Mattoso reforça insistentemente sua identidade literária, fruto das leituras da poesia de Bocage e Gregório de Matos. No final do livro Geléia de rococó: sonetos barrocos (1999), GM aponta algumas considerações teóricas acerca da construção do soneto e defende a forma fixa como uma das maiores invenções do homem:

Não considero que o soneto tenha sido formalmente superado. Faço minhas as palavras de Fausto Cunha a propósito do temporão, porém perene Livro de Sonetos (1949) de Jorge de Lima: "A própria questão do soneto como soneto tornar-se-ia, aqui, bizantina. Sempre vi (e mais de uma vez o escrevi) no soneto a maior conquista formal da poesia em todos os tempos, razão pela qual tenho olhado com ceticismo os que lhe agoiram a decadência." Dou-me ao luxo de pilheriar que o soneto vem a ser a maior invenção do Homem, depois da roda, do alfabeto latino, do algarismo arábico e da própria notação musical. (MATTOSO, 1999, p.123) 
Em mais de 5.000 sonetos publicados, fica difícil apontar todas as referências poéticas citadas por elementos intertextuais e influências nas rimas construídas. Glauco Mattoso vai do clássico à oralidade, valorizando o espaço poético em todas as instâncias. O soneto, a glosa, o haicai, o cordel, o repente, a música... São nítidos os conhecimentos teórico e histórico dos textos e contextos da poesia, desde o mais erudito ao popular. O retorno que Mattoso faz à construção poética em forma de soneto é também uma forma de eternizar na escrita seus poetas admirados.

Em parte da sua obra "sonetária", adjetivo por ele mesmo calcado, notase uma linguagem com característica de crônica, em que acontecimentos cotidianos e factuais são trazidos e ficcionalizados nas linhas de um eu-lírico corroído pela dor da cegueira.

O soneto "Policial", em Poética na Política (2004), apesar de mais de 10 anos da sua publicação, faz-se atual quanto à relação do povo brasileiro com a política nacional:

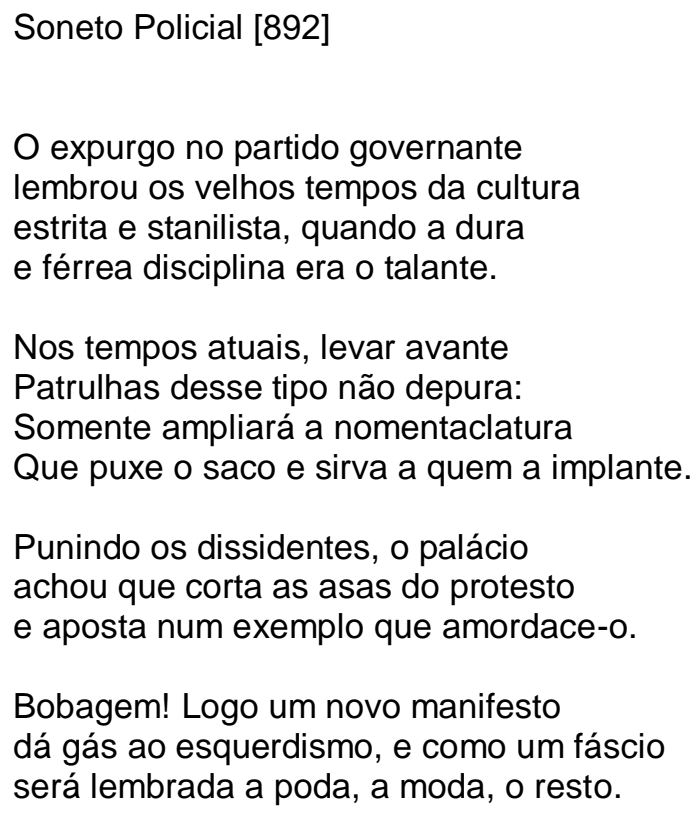

(Mattoso, 2004, p. 47)

Em Mattoso, entende-se que o soneto funciona como qualquer outro processo sistemático, em que quartetos e tercetos são raciocinados a partir da organização entre métrica, ritmo e acentos, formando um conjunto funcional 
extremamente eficaz para alguém desprovido de visão e muitas ideias para criação. O espaço do soneto, diz Mattoso,

foi a minha tábua de salvação para voltar a escrever. Além de ter um potencial mnemônico muito forte, indispensável para mim em função da cegueira, o soneto dá ainda essa possibilidade de desenvolver um raciocínio completo. É uma fôrma que preenche todas as minhas necessidades. É uma invenção fabulosa, mágica, perfeita...Você pode, é claro, mudar a posição dos versos, como no soneto inglês, shakespeariano, que possui os mesmos quatorze versos, porém dispostos de outra maneira. Mas parece que, nessa forma tradicional, duas quadras e dois tercetos, ele se tornou perfeito, acabado. ${ }^{42}$

O verso, como linha de sentido temporariamente "completa" pelo ritmo, tem como lugar aspectos fundamentais quanto ao gráfico e ao sensório. Sua composição depende bem mais da estrutura como reiteração das vozes, que elementos de significações. O jogo entre a disposição gráfica e elementos estruturais delimitam a escolha meticulosa das palavras, em que a linguagem rítmica reveste expressivamente o particular de cada soneto.

\subsection{O espaço do cego: a memória visual}

O espaço ocupado por quatorze versos é um espaço seguro, cujo poeta transeunte conhece cada letra ali disposta. Para um cego, ter definida previamente a forma que irá ocupar a folha (tela) em branco é uma segurança no processo de criação. Segundo Mattoso, todos os seus sonetos são frutos da insônia, natural do processo gradativo da cegueira e da angústia dos pesadelos de estar cego e, ao acordar, continuar cego.

As leituras armazenadas na memória de GM são instrumentos fundamentais para seu processo de criação. O soneto para ele é um espaço plurilinguístico, em que a ressonância das palavras transita num emaranhado intertextual, cujas lembranças de acontecimentos marcados na memória

\footnotetext{
42 Entrevista do autor disponível em: http://www.memorial.org.br/cbeal/poetas-na-
} bilbioteca/glauco-mattoso/entrevista-mattoso/ 
dialogam com as leituras feitas de outros sonetos, de outros tempos, de outras histórias, de outros poetas.

Enquanto indivíduo cego, limitado pela ausência de um dos sentidos, driblar essa condição é explorar ao extremo os demais sentidos - que, no caso de GM, parte do som gerado pera rima dos versos.

Quanto ao espaço visual, é comum, para um cego, querer habituar-se e reconhecer cada milímetro da localidade por ele ocupada. Mattoso transfere esse reconhecimento para a tela do computador. Ao pensar a "folha" em branco, ele já delimita em catorze versos as palavras que ali serão ancoradas, de modo a manter-se firme e dominador desse espaço, seja por necessidade de acabamento, seja pelo conforto do controle.

O texto em prosa é mais solto. As palavras colocadas em períodos podem se perder no fluxo das ideias, na medida em que a escrita começa. A rima não. Os versos dos sonetos são "feitos de cabeça", enquanto Mattoso se angustia com o passar das horas nas noites de insônia, e o ritmo dá conta dessa fixação na memória, a ponto de, no outro dia, lembrar-se daquele poema composto e do som gerado por ele.

O soneto, enquanto escolha limitada em 14 versos, é fruto de um processo dinâmico, em que a relação com as formas precisa ser respeitada e 0 conhecimento da técnica é imprescindível para que ele aconteça.

O jogo intertextual construído por Mattoso em sua obra, tanto da fase visual, quanto cega, parece articulado e premeditado. Como alguém que se alimentava da literatura de maneira alucinante e adquiria um repertório literário de erudição, reverberar essa teia construída na memória requereria espaço e a arte lhe garantiu isso.

O processo dialógico em Mattoso, num retorno à Bakhtin, acontece não só quanto à intertextualidade proposta por Julia Kristeva (1969), em que o diálogo entre textos emana enquanto presença da palavra, mas numa relação da figura do autor, do "eu-Mattoso", com leituras afixadas na lembrança e sua relação com elas, numa dinâmica de enunciados e vai-e-vem da escrita enquanto retorno a outras estéticas e autores.

Kristeva, em Introdução à Semanálise (1969) define o texto como "aparelho translinguístico", em que a palavra se comunica com diferentes enunciados, num cruzamento de textos e no que ela defende como "mosaico 
de citações". A relação intertextual proposta por Kristeva traz vestígios do eixo de interação entre Eu vs. Outro de Bakhtin, em que o dialógico e a ambivalência contemplam os conceitos discutidos pelo filósofo, embora Kristeva não os traga de maneira objetiva e reformulada.

Em Marxismo e Filosofia da Linguagem (2014), a dinâmica dialógica de enunciados, compreendida por Bakhtin, expõe a palavra como território compartilhado, movimentado por locutor e interlocutor, por vozes e enunciados, por linguagens.

A memória de Mattoso é uma "memória intertextual", em que, ao lado das experiências vividas transitam as leituras, em igual importância histórica, formulando um conjunto dialógico daquilo que lê e escreve. Sua escrita mistura o empirismo com a literatura, em que a rememoração, de acordo com Paul Ricoeur,

opera na esteira da imaginação. Ora, a imaginação, considerada em si mesma, está situada na parte inferior da escala dos modos de conhecimento, na condição das afecções submetidas ao regime de encadeamento das coisas externas ao corpo humano. (RICOEUR, 2007, p. 25)

Num período em que a cultura visual ${ }^{43}$ espalhada e espelhada em imagens ofusca o olhar atento do sujeito observador, não estamos muito distantes da cegueira, devido à dificuldade de leitura demorada, aprofundamento e exploração das imagens, diferente de só enxerga-las e julgá-las pelo processo simplista do gosto. Ainda, com mecanismos digitais que permitem armazenar infinitos conteúdos de maneiras múltiplas, não há mais necessidade de uso efetivo da memória para guardar informações, imagens, representações e, principalmente, conhecimento. Está tudo acessível na tela do computador, na internet, no HD portátil, nos sites de buscas, nas redes sociais...

\footnotetext{
${ }_{43}$ Pensamos em Cultura Visual do ponto de vista da arte na educação, pela perspectiva de Fernando Hernandez, em Cultura Visual, Mudança educativa e projeto de trabalho (2000), quando associa a cultura visual às relações com arte, imagem, produto cultural, publicidade e consumo. Ele fala da "miopia" em relação à observação e "consumo" das imagens, em que o indivíduo em formação sente dificuldade e interpretar, compreender, refletir, vivenciar a arte. (2000, p. 27-28)
} 
No momento da composição de seus sonetos, romances, crônicas, glosas, Mattoso, de certa forma, além de ir contra um período em que a memória já não tem tamanha relevância para o processo de diálogo e referência, reescreve a literatura e mantém uma história, compondo, por meio a fragmentos intertextuais, novos enunciados em novas interpretações. É um movimento giratório da escrita pelas linguagens artísticas em seu processo de catalisação de elementos e significações. Para Antoine Compagnon,

\begin{abstract}
O trabalho da escritura é uma reescritura, visto que se trata de converter elementos separados e descontínuos num todo contínuo e coerente [...] Rescreever, realizar um texto a partir de seus fragmentos, é arranjá-los ou associá-los, fazer as ligações ou as transições que se impõem entre os elementos presentes. Toda escritura é colagem e glosa, citação e comentário. (COMPAGNON apud SAMOYAULT, 2008, p.35)
\end{abstract}

O jogo de enunciados recortados da memória de Mattoso e inseridos em seu processo de criação formam imagens de textos lidos e imagens dialogadas na mente por um sistema interpretativo natural e individual. A forma como temos acesso às nossas lembranças é uma evocação de algum estado, cuja consciência quer definir, embora esteja completamente embaraçada ao presente. Com uma escrita confessional, Mattoso se utiliza da memória também para recuperar acontecimentos da infância e adolescência, transpassando-os para as palavras a partir da lembrança que carrega. Mas a memória é traiçoeira e turva. Ela possui uma névoa que encobre uma realidade que acreditamos tê-la armazenado em nossa mente, sem darmos conta de que, a cada rememoração, uma nova interpretação.

Não há como negar que a arte literária, enquanto escrita, é processual e sistemática, pois traz o elemento racional da criação pela memória. Concordamos com Foucault quando diz que

O papel da escrita é constituir, com tudo o que a leitura constitui, um 'corpo'. E é preciso compreender esse corpo não como um corpo de doutrina, mas sim - segundo a metáfora da digestão, tão frequentemente evocada - como o próprio corpo daquele que, transcrevendo suas leituras, delas se apropriou e fez a sua verdade delas: a escrita transforma a coisa vista ou ouvida em forças e em sangue. (FOUCAULT, 2010, p. 152 - grifo nosso) 
Henri Bergson, em seu estudo sobre a memória e a forma como buscamos materializá-la em nossa realidade, presente em Matéria e memória (1999), fala da relação da lembrança com o processo de constituição de imagens e representações. Utilizando-se de metáforas imagéticas, o filósofo permeia por discussões sensíveis acerca da lembrança e do processo de interpretação dessas lembranças, na busca pelo conceito de imagem.

\begin{abstract}
E por "imagem" entendemos uma certa existência que é mais do que aquilo que o idealista chama uma representação, porém menos do que aquilo que o realista chama uma coisa - uma existência situada a meio caminho entre a "coisa" e a "representação" (BERGSON, 1999, p. 2)
\end{abstract}

As imagens em Glauco Mattoso foram solidificadas na figura metafórica de um elemento: o pé. Ao retomar o passado, seja da infância ou qualquer outra fase de sua vida, Mattoso resgata situações de dor, sofrimento e humilhação, contraditoriamente rememoradas como possibilidades de prazer e gozo, representadas pela figura do pé no rosto dele ou da sua língua no pé de alguém. O pé é ressignificado na escrita de GM pelo espaço que ocupa, como territorializador, como firmador da relação do indivíduo que compõe com o espaço empírico de imagens, de sentimentos, de dor e prazer. A planta do pé, a raiz que sustenta a existência do escritor que é cego, converte-se em um conjunto de configurações e comprometimento da linguagem com seu emissor. 


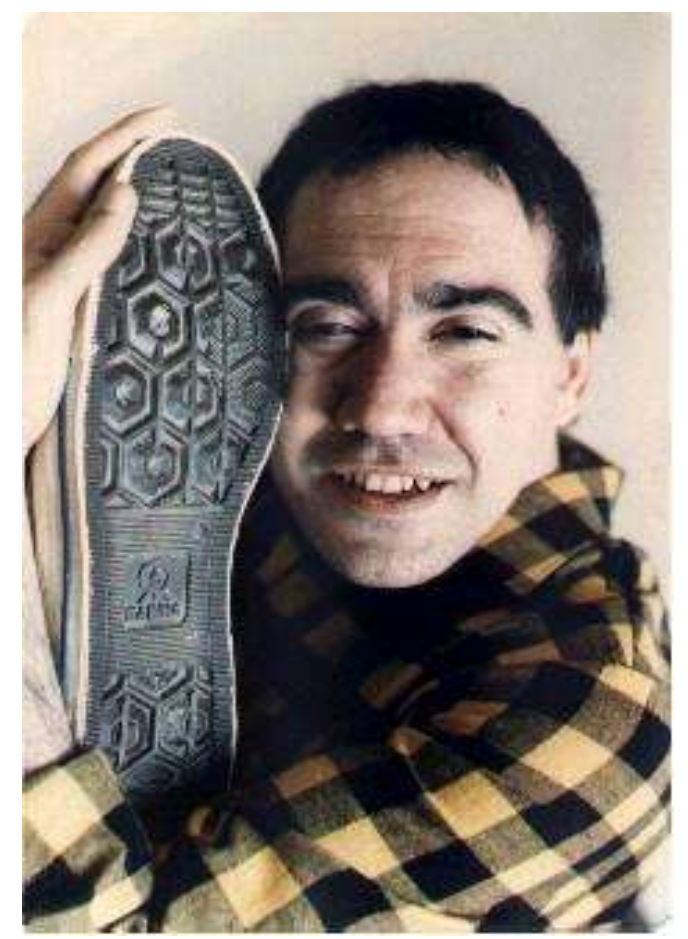

Figura 33- Glauco Mattoso - foto de Rubinho Chaves

A imagem acima (fig. 33) é uma das que Mattoso mais gosta. Em inúmeras entrevistas (apesar da pouca fortuna crítica, têm-se, no meio virtual, um número considerável de entrevistas do autor $)^{44}$, ele relembra a imagem e o tamanho do tênis que ganhou, numa irônica representação do seu fetiche. Feita, provavelmente, ainda no período em que Mattoso enxergava, nota-se na foto que um dos olhos já perdeu a cor e está mais protuberante que o outro. $A$ imagem que Mattoso tem de seus olhos hoje são também mencionadas por ele no Filme para poeta cego ${ }^{45}$, um curta-metragem de Gustavo Vinagre, de 2012.

As referências insistentes ao bullying são trazidas na composição dos sonetos como imagens de cenas da infância de Glauco na escola e de como, desde pequeno, o glaucoma tornou-se um limitador em sua vida social. Como o gatilho para o fetiche por pés do autor, cenas de humilhação e opressão sofridas por ele são dialogadas com o arsenal literário adquirido, numa mistura de memória do que viveu com memória do que leu.

\footnotetext{
${ }^{44}$ Ao fazermos referência à diversas entrevistas, estamos cientes do quanto a fala do autor pode ser tendenciosa e direcionadora enquanto elemento interpretativo de sua obra. Procuramos, primeiro, mergulhar no texto sem nos atermos, diretamente a esses elementos extratextuais. Em segundo plano, ouvir e compreender o que o autor tem a dizer sobre seu próprio trabalho também permite um olhar mais atento para chegarmos à gênese de seu processo criativo.

${ }^{45}$ Vídeo completo aqui: https://www.youtube.com/watch?v=s2QM5DwzXDo
} 


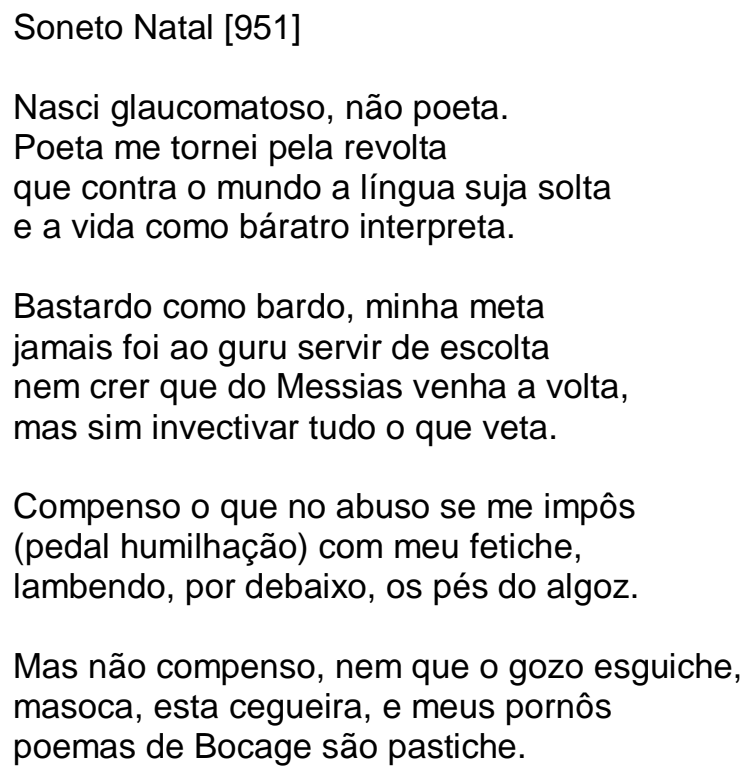

Mattoso defende a ideia de um sadismo e masoquismo miscigenados em suas múltiplas manifestações da libido a partir do olhar fetichista, especificamente, das cenas construídas, primeiramente, na memória, para depois serem discorridas e reinterpretadas pelas palavras. Sua afixação por pé é também uma forma de representação imagética que retoma o incidente de sua vida, ao passo que desencadeia um processo de criação de cenas, vividas ou não, mas expostas nas rimas dos sonetos e nos períodos dos contos e romances.

\subsection{Soneto $v s$. Imagem: a forma fixa do verso figurativo}

A origem do soneto, ainda na Idade Média, veio como forma organizada e ritmada de melodias cantadas por poetas provençais. A sonoridade e rima, toadas importantes para composição da letra, dependiam mais do envolvimento rítmico e performance da declamação que do peso e reflexão de seu conteúdo abordado nas palavras. Com o passar do tempo, e a pluralidade de escritores da modernidade vinculados a movimentos, o soneto foi variando de acordo com estéticas e passou a versar sobre temas tão significativos 
quanto os discursos da própria história e da literatura, enquanto espaço amplo de questões existenciais.

Com destaque para o sistema da forma, tem-se, no soneto, uma visualidade aparente que, embora não seja sua principal intenção, formula visualmente uma estética constitutiva da disposição das palavras escolhidas pelos sonetistas.

A essa altura do nosso texto, é desnecessário reforçar a figura do poeta Glauco Mattoso como um dos maiores sonetistas, mas é importante compreender as nuanças da sua relação entre a visualidade do poema (concreto) do DOBRABIL com a visualidade do soneto escrito às cegas.

Qual o espaço que a imagem ocupa nas palavras descritas pela literatura de Glauco Mattoso? Numa digressão acerca da imagem, principalmente na relação da representação das artes plásticas com a literatura, ainda num momento clássico, observamos o diálogo forte entre essas linguagens e suas manifestações.

Em um retorno ao simbolismo de Charles Baudelaire e Guauguin, dois grandes nomes simbolistas, da literatura e artes plásticas, respectivamente, tem-se neles uma preocupação em ir além da realidade, na busca por uma essência. Entretanto, embora o movimento do qual eles pertenciam tenha se proposto antagônico às manifestações realistas e naturalistas, são nas coisas concretas, cotidianas e "reais" que o simbolismo irá fundamentar sua expressão enquanto sensibilidade artística.

As formas sensíveis buscadas por artistas da época, em suas mais diversas possibilidades, exploraram elementos que vão do erótico e perverso ao místico. Mais do que isso, o Simbolismo pode se dizer de um momento característico de representação da morte, da doença e do pecado (CHILVERS, 2007, p.493-494).

Dessa feita, é possível ver a relação de Mattoso com características simbolistas no que tange à exploração de questões negativas ao sujeito e sua condição humana. Ademais, é no simbólico representado pelo autor que os versos fomentam traços imagéticos acerca da significação das palavras versadas.

A concretude nos sonetos do autor está posta, não por sua visualidade enquanto palavra, simplesmente, mas no conjunto conceitual do que ela 
representa enquanto cenas de um acontecimento, gerando, nitidamente, uma representação mental (visual) daquilo que está sendo narrado no soneto. A exemplo, temos o soneto de um dos seus recentes livros publicados, Poesia vaginal (2015):

MENINA MIMADA [3960]

A filhinha à mãe pedia, insistente, uma boneca.

A mamãe resiste, addia, mas, emfim, já não diz "Neca!"

A boneca, que queria a menina, até defeca! Peida, arrocta, o dedo enfia no nariz, tira melleca...

Bem que a mãe desconfiava: quer a filha ter a escrava que fiel ser lhe prometa...

Por um lapis penetrada no cuzinho, a Barbie agrada, com a língua, outra boceta...

(MATTOSO, 2015, p.153)

A visualidade, enquanto construção imagética por meio da representação, está clara nas palavras escolhidas para dar conta do tema tratado no livro e é facilmente construída pelo leitor, embora possua embates morais fortes que rompem com a cena representada mentalmente pela leitura. Com palavras que geram um figurativo simples, a complexidade está na situação causada pelas escolhas linguísticas e os efeitos significativos dos elementos compositores do poema. A criança, a boneca, a mãe, a Barbie, um lápis, a meleca, a boceta... o conjunto de significantes dado por Mattoso começa a destoar quando questões do corpo com do desejo e do prazer estão relatados pelas necessidades e mimos de uma criança. Uma criança do sexo feminino, cujo invólucro em torno, não só do sexo ou da sua condição socialmente inferior diante de uma sociedade patriarcal, mas a sua humanização enquanto desejosa e praticante da masturbação por meio do brinquedo. 
Temática complexa e, consequentemente, fecunda para discussões além da literatura, por estar presente no soneto de Mattoso corrobora para uma arte que extrapola os espaços sígnicos das discussões, eufemizadas em torno do corpo e de sexo da criança. Para nós, que optamos por ficar apenas no terreno da estética, compreendemos que essa escolha feita pelo artista, embora traga consigo necessidade referencial robusta no que tange à psicanálise, é notoriamente um elemento racional de concretude daquilo que pode ser visualizado na mente e representado pelas palavras.

Poder-se-ia dizer aqui que Mattoso é um desenhista do significado, pois possibilita, por meio da escrita, a construção figurativa daquilo que somos incapazes (moralmente) de aceitar em pensamento, de discutir ou representar por imagens, devido aos nossos embates entre uma ética que se propõe antagônica à estética da criação. 


\section{Segunda parte \\ O AUTOFICCIONISTA}

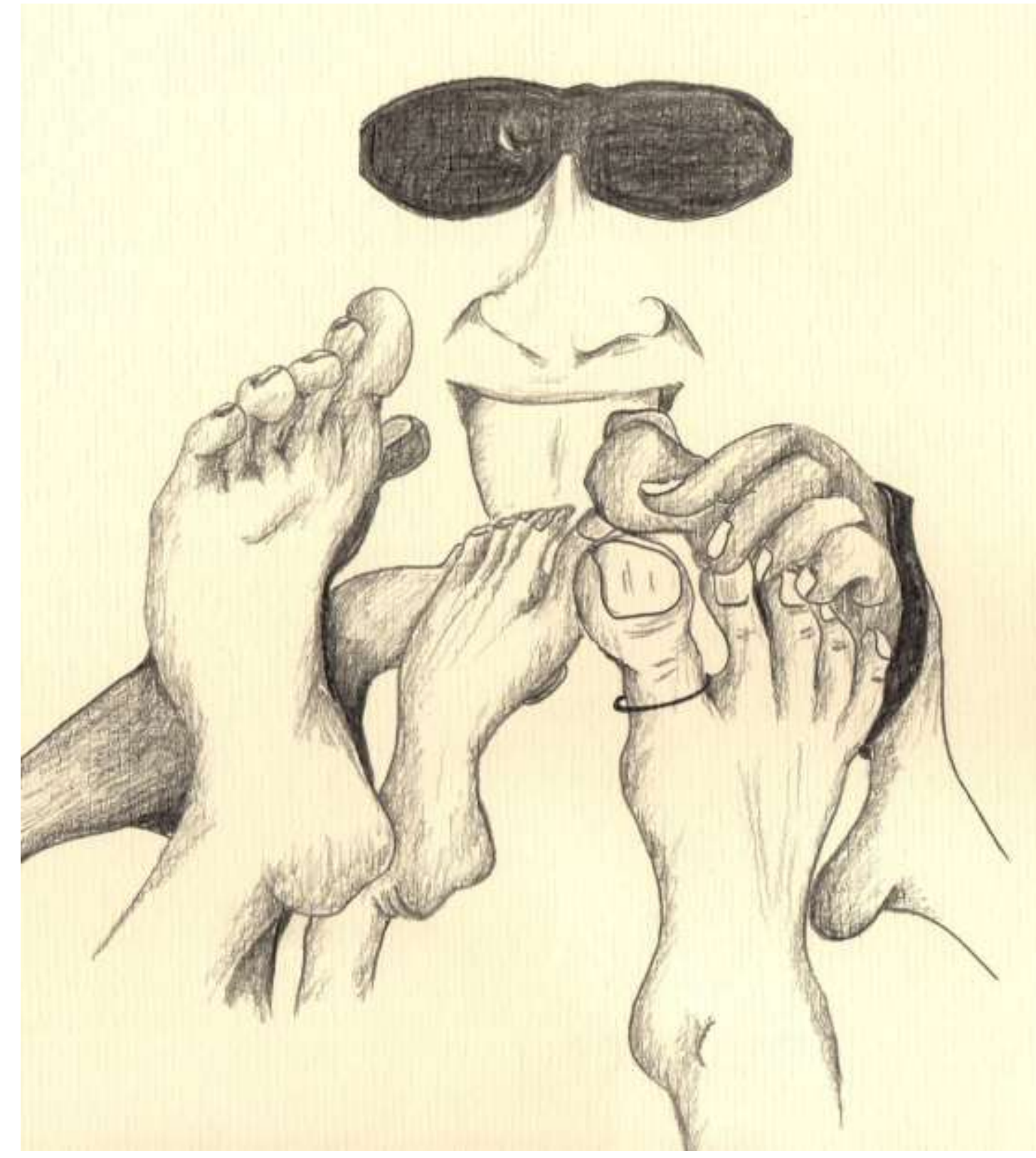

Fricções, Ana Paula Caixeta, 2013. 
"Nunca tive veleidades literárias, no sentido de estar fazendo algo original, inovador, ou de vanguarda. Isso não existe. No Brasil, confunde-se vanguarda com elitismo, talvez porque num país semi-analfabeto há pouco espaço pra erudição, e toda \& qualquer pesquisa estética, seja na área de criação ou de crítica, parece grande avanço. Em terra de leigo, original é quem plagia primeiro. Para um bom bibliotecário, não existe nada original. A única diferença entre o plagiado e o plagiário é que o nome do primeiro já constava das obras de referência e dos catálogos..." (MATTOSO, 2006, p. 143)

O Manual do podólatra amador é, para nós, a obra mais desconcertante de Glauco Mattoso. Do conteúdo autoficcional à descrição de cenas sadomasoquistas, que afrontam o politicamente correto com relação à tortura e humilhação do cego, o que também nos chama atenção nesta obra é o reforço identitário da persona Glauco Mattoso como um escritor maldito. O "arsenal" literário do autor, transcrito por inúmeras páginas do texto num diálogo de enunciados, funciona como uma explosão intertextual entre o processo erudito de Glauco Mattoso e a dor da condição da cegueira, metaforizada pela figura do pé. Isso resume bem o objeto de nosso interesse para norteamento de uma estética enquanto estudo teórico.

O contexto percorrido anteriormente, embora sem grandes aprofundamentos, significou bastante para a formação do olhar de pesquisador outrora aqui comentado. Notar-se-á, adiante, com a leitura do Manual, as relações importantes entre as fases de criação de Mattoso, mas, principalmente, como essas fases retornam à escrita daquele texto que é considerado "autobiográfico". 


\subsection{Narrativas de um glaucomattoso}

Com uma distância de 20 anos entre as duas publicações, as obras já são sugestivas a partir dos elementos simbólicos consistentes naquilo que compreendemos como objeto-livro: o livro enquanto coisa, carregado de visualidades que contemplam características expostas externamente. As imagens contidas, principalmente nas primeiras capas das obras do autor (anteriores ao Manual), aparentam um mesmo traço e, supostamente, a mesma origem. Ao que consta na Revista Dedo Mingo (1982), Mattoso, ao viajar na década de 1980 para os EUA, adquiriu alguns arquivos das ilustrações de um artista em uma loja sadomasoquista. Estas foram todas "pirateadas" por Mattoso e estão presentes, tanto no JORNAL DOBRABIL, como Revista Dedo Mingo e nesta primeira edição do Manual do pedólatra amador (fig.34).

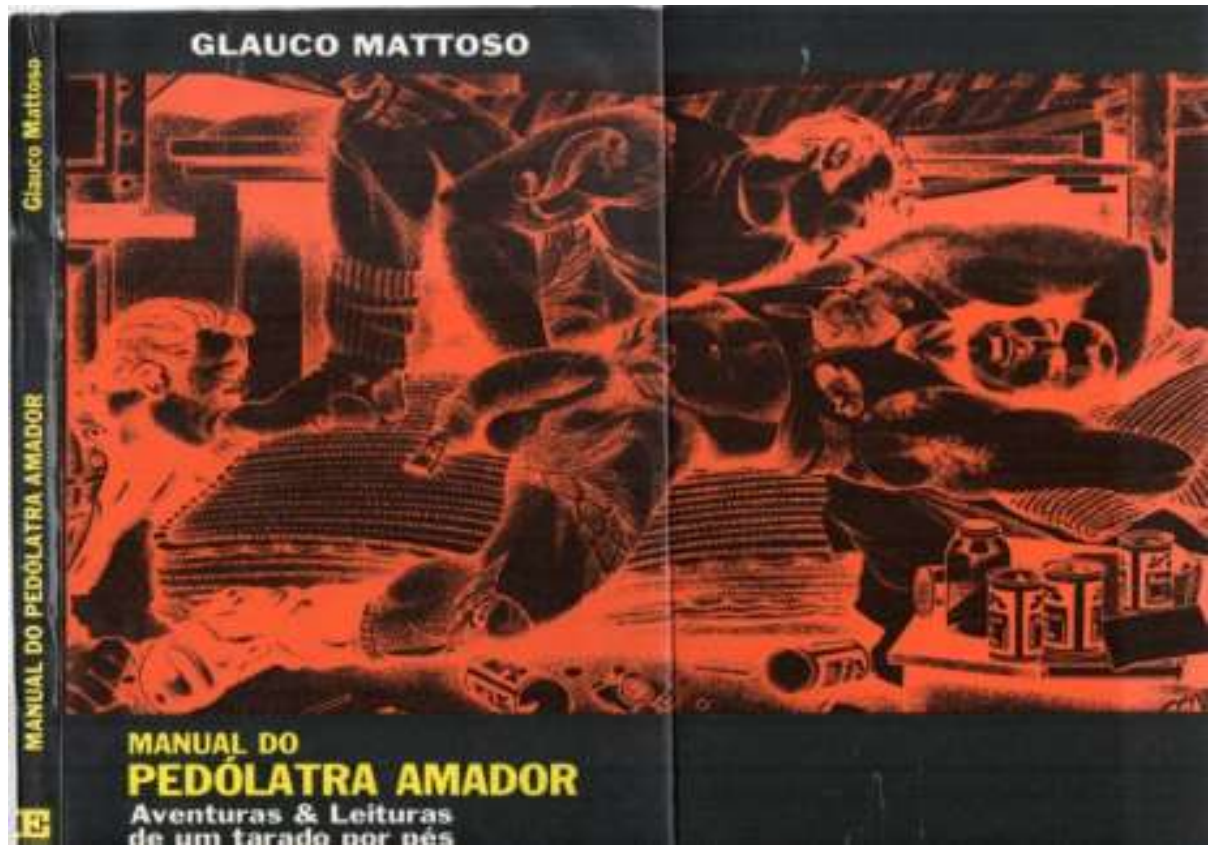

Figura 34 - Capa e orelha do livro Manual do pedólatra amador, 1986.

Chama a atenção pelo efeito negativo em vermelho que, de certa forma, ameniza o impacto da imagem erótica (e apropriação indevida dos direitos 
autorais da imagem), em que um homem lambe os pés de outro. A orelha do livro (fig. 34) complementa a imagem de capa e traz um terceiro indivíduo, que lambe os mamilos daquele cujo pé também é lambido. Nota-se que, o que está recebendo as carícias está numa posição de entrega de suas partes erógenas, consentindo com as ações dos dois acariciadores, numa representação imagética fetichista. Os elementos denunciadores vão desde o cadeado no membro sexual de um dos indivíduos à ação de lamber pés, reforçando as questões abordadas no texto de Mattoso sobre sadomasoquismo.

No verso da capa, ações eróticas são didaticamente enumeradas como forma de credibilizar o título "manual" (fig. 35):

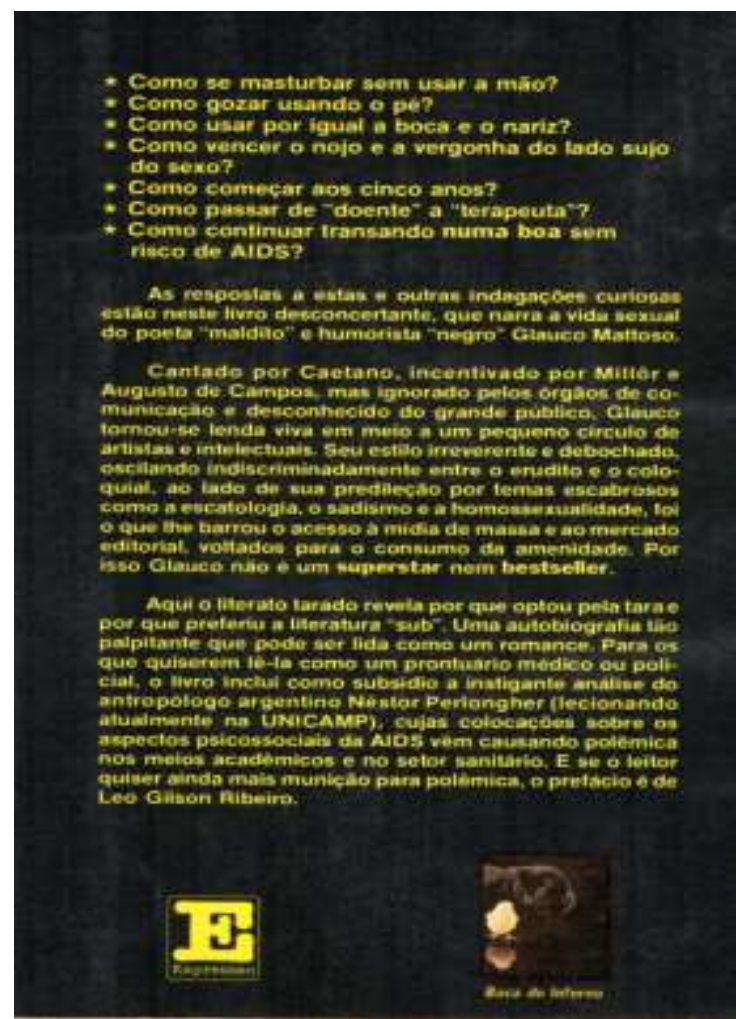

Figura 35 - Verso da primeira edição, Manual do pedólatra amador, 1986.

Glauco Mattoso, como um lexicógrafo ${ }^{46}$ e sua necessidade de conceitualização etimológica de termos, traz a palavra manual na capa do que, na época de publicação, era considerada sua autobiografia. Obviamente o leitor compreende, pelo título, ao menos duas coisas. A primeira: um passo a

\footnotetext{
${ }^{46}$ Glauco Mattoso é também lexicógrafo e escreveu o dicionário de palavrões bilíngue: Dicionarinho de Palavrão \& correlatos - Inglês/Português, Português/Inglês (2005), além do Diccionario Orthographico Phonetico/Etymologico.
} 
passo erótico, tendo em vista a capa e o termo "pedolatria" (1ª edição), seguidas das informações contidas no verso da capa. Segunda possibilidade de interpretação: uma história de quem vive esse passo a passo obtendo êxito e, didaticamente, pode "ensinar". Mas o teor do conteúdo da narrativa não é tão didático assim.

Levar em consideração esses elementos paratextuais, de acordo com o que Gerard Genette propõe (2006), é compreender as possibilidades de mediação entre leitor e obra. Mais do que isso, esses elementos definem, muitas vezes, a escolha da leitura. A força da imagem de capa é explorada não só pelo autor do texto, mas pelas editoras, que, por vezes, são detentoras da escolha e diagramação, a partir da interpretação do artista gráfico. Ademais, a capa é o primeiro contato visual do leitor com o objeto de leitura.

O que mais nos chama atenção na capa é forma como o texto convida o leitor a uma leitura erótica, talvez divergente do que se propõe a própria narrativa, em que a tortura e a violência sexual, a sexualidade, o sexo na infância e a dor da cegueira compõem as ações narradas e dialogadas por aquele que é autor-narrador-personagem e desconstrói o título sugestivamente didático, atraente e até despretensioso. A tríade construída entre o sujeito que escreve, que vivencia a história e a narra fomenta uma identidade de escrita interessante, pois corrobora para uma relação entre realidade e ficção mais diletante, do ponto de vista daquele que cria.

Conforme consta no verso, a primeira edição traz o prefácio de Leo Gilson Ribeiro ${ }^{47}$ e um posfácio de Néstor Perlongher ${ }^{48}$. Começando pelo prefácio, Ribeiro apresenta Mattoso a partir do seu marco literário, o JORNAL DOBRABIL, bem como a relação do poeta com desenhistas humoristas, como Millôr, Jaguar e Lessa. O prefácio coloca o Manual como integrante de uma seleta literatura erótica, que vai de Jean Genet a Dalton Trevisan.

Na segunda página do posfácio, Ribeiro chama o texto de autobiografia, complementando o que já constava no verso da capa:

\footnotetext{
${ }^{47}$ (1930 - 2007) Jornalista e crítico literário, doutorou-se em literatura na Alemanha, onde também foi professor de Literatura Brasileira. Foi crítico literário e teatral; colaborou com diversos veículos da imprensa, nacional e internacional.

${ }^{48}$ (1949-1992) Poeta argentino, foi arqueólogo e considerado um anarquista. Na Argentina, foi um grande militante pelos direitos dos homossexuais. Veio para o Brasil em 1982.
} 
Este Manual do pedólatra amador, com o subtítulo de Aventuras \& leituras de um tarado por pés, costura grande parte da autobiografia de Glauco Mattoso com trechos de obras célebres da littérature cochone de vários autores. (RIBEIRO in MATTOSO, p. 6, 1986)

Para esta pesquisa, em especial, o reforço dado ao texto de Mattoso como autobiografia é uma das nossas discussões (para não dizer contestação), principalmente ao se pensar em duas edições com diferenças em suas publicações.

Quanto à segunda edição, talvez mais comedida em seus elementos visuais e paratextuais, a imagem de capa (fig. 36) é uma obra de Vincent Van Vogh (fig. 37), datada de 1886 (exatos 100 anos antes da publicação do Manual). Os três pares de sapato compõe uma série de quadros pintados pelo artista sobre sapatos - a maioria, botas masculinas.

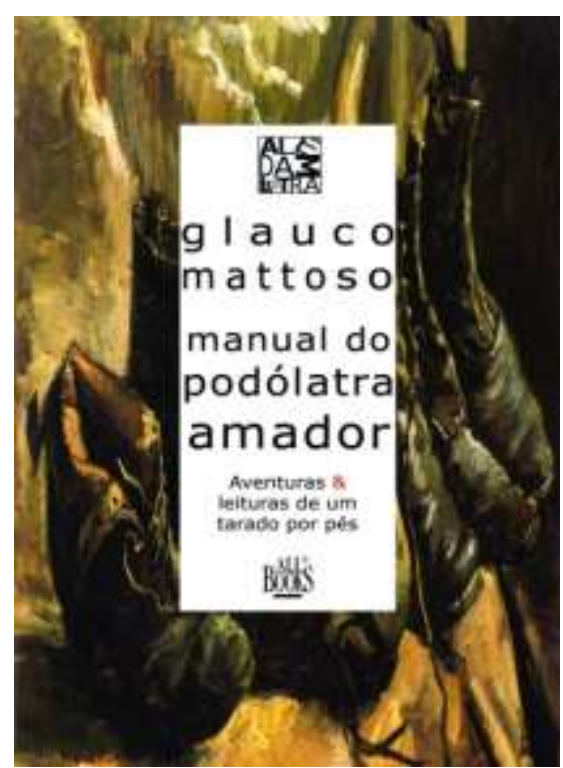

Figura 36 - Capa da segunda edição do Manual do podólatra amador, 2006. 


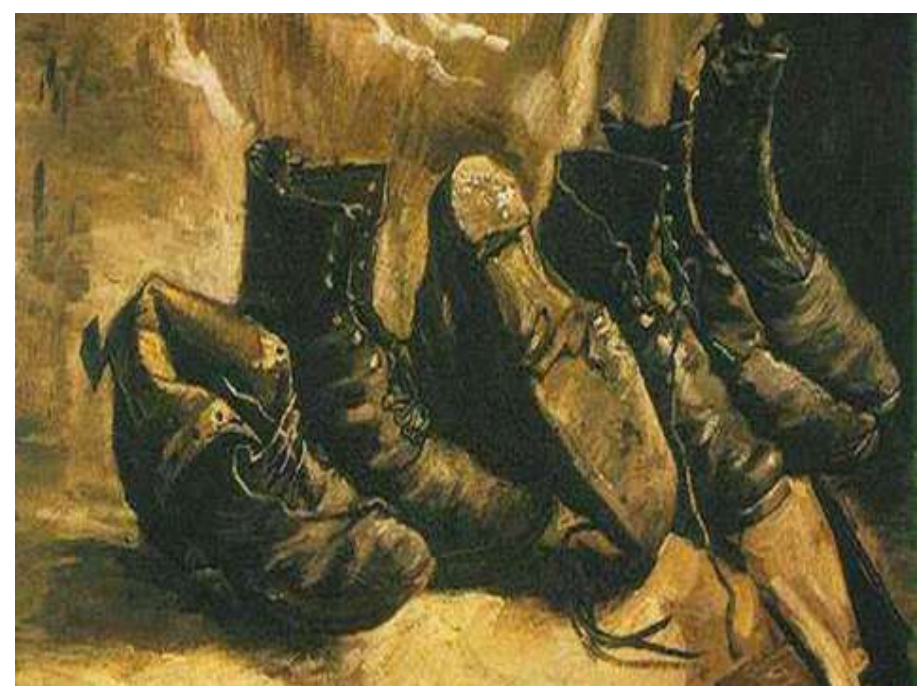

Figura 37 - Os três pares de sapato, de Van Gogh, 1886.

Já no verso da capa da segunda edição, há trechos de divulgação do livro na época de lançamento da edição de 1986, publicados no Jornal do Brasil, na revista gaúcha Cobra e no jornal $O$ Globo, credibilizando, de alguma forma, o espaço social/literário ocupado pelo texto. Embora as edições sejam reforçadas com prefácios e posfácio de especialistas, o Manual não foi bem recebido na época da $1^{\underline{a}}$ edição. $O$ livro teve uma recepção polêmica e foi comentado com asco por muitos, como Hebe Camargo em seu programa ${ }^{49}$. A obra foi interpretada como "nojenta" e de "mau gosto" enquanto fomentadora da ideia de um manual para ser lido e "praticado".

O relançamento do livro 20 anos depois, tal qual como o DOBRABIL, trouxe algumas diferenças da primeira edição. Mattoso, além de alterar o nome "pedólatra" para "podólatra", justificando lexicograficamente a escolha, também adiciona um capítulo, com considerações após a cegueira - já que a primeira edição é do período em que Mattoso ainda enxergava. Fora essas diferenças pontuais, há também alterações de alguns trechos e/ou frases acrescentadas em meio à narrativa, corroborando para o que chamaremos, mais a frente, de autoficção.

\footnotetext{
49 Informações disponíveis no portal Cronópios, do qual Mattoso é também colaborador. < http://cronopios.com.br/site/lancamentos.asp?id=1400>
} 


\section{2 "Pedo" e "podo": para além de uma questão léxica}

"Pedolatria. A palavra não está dicionarizada, talvez por ser híbrida. Meio salto, meia sola; meio sapato, meia meia. Pedo (pé) vem do latim pedis; latria (adoração), do grego. Não é o mesmo caso de pedofilia, onde o pedo vem do grego (criança), como filia (amor). Pra ser genuína, a palavra teria que ser toda latina ou toda grega. Isso é o que pensam os puristas do vernáculo. Algo do tipo podofilia ou podolatria, ondo PODO é o elemento grego que dá pé. Ou então pedialidade, ou pesturbação: não existem cordialidade (cordis = coração) e masturbação?" (MATTOSO, 2006, p. 15 - destaque do autor)

Começando com a primeira edição (1986), no primeiro capítulo, "Dos Significados Insignificantes", há, antes do texto, a imagem da capa do JORNAL DOBRABIL cuja ilustração dialoga com a capa do Manual. A retomada imagética do JD logo no início do livro mostra o diálogo e a ligação com essa primeira publicação e a escrita do texto aqui analisado. Isso será observado em outras obras de Glauco, bem como sua insistente revisitação nas próprias publicações, fomentando a presença de uma autotextualidade ${ }^{50}$, em que 0 autor cita a si mesmo.

O primeiro livro (1986) está organizado em cinco partes, mais um prefácio e um posfácio. Já o segundo (2006), contém seis partes mais uma nota do organizador da coleção, o escritor e psicanalista Sérgio Telles; e uma apresentação feita a partir de fragmentos escritos pelo pesquisador David Willian Foster, ao publicar um texto sobre o Manual, relacionado à primeira edição.

Os capítulos comuns às duas edições são: Dos significados insignificantes, em que o autor define o termo pedolatria (1986) e, posteriormente, fala da alteração para podolatria (2006); Dos objetos abjetos, em que a definição e solidificação do fetiche são elementos formadores; e) Dos cheiros Chulos, parte cujo odor é central na trama; Dos versos perversos

\footnotetext{
${ }^{50}$ A ideia de autotextualidade está pautada no livro Intertextualidade: Diálogos possíveis (2008) de Ingedore Villaça Koch, Anna Christina Bentes e Mônica M. Cavalcante.
} 
aos palavrões-de-ordem, espaço em que Glauco narra sua inserção no espaço literário; Das cartas curtas às solas grossas, em que o autor cria a "massagem linguopedal", divulgada por meio de panfletos. A sexta parte, Do pré-pé ao pós-pó, contida na segunda edição, momento em que o autor revisita a obra e a descreve sob um olhar após a cegueira.

Em geral, o texto pode ser resumido como as aventuras de Glauco da infância à fase adulta, da visão à cegueira, da humilhação ao gozo, do leitor ao escritor. Na busca pela espiritualização do sensível, usando aqui uma referência hegeliana, Mattoso humaniza, no texto, sua ideia de humilhação e degradação por meio de uma estética particular, reforçada pelo que aponta Ariano Suassuna:

No seu anseio de captação do mundo, o homem sente a oposição entre sua natureza espiritual e a realidade bruta que o cerca. Tendo, porém, por um impulso irresistível, que receber esse mundo cego dentro de si, procura espiritualiza-lo, para diminuir a diferença e a oposição.

[...] o homem procura humanizar as coisas, inserindo a Ideia no sensível. (SUASSUNA, 2009, p.92)

Glauco (nascido, no livro, Glauco e não Pedro) conta, em primeira pessoa, a trajetória da sua vida de maneira cronológica, permeada por situações sexuais que o definem como fetichista-masoquista. A narrativa é intercalada por textos com citações diretas e indiretas, caracterizando o livro com elementos de uma escrita acadêmica, em que fragmentos são trazidos, comentados e dialogados, sustentando as escolhas e peripécias do narrador e formulando um texto numa espécie de tese podólatra - cujas reflexões são aprofundadas a partir da presença do autor enquanto sujeito que pensa, filosoficamente, sua condição de fetichista.

Muitas são as personagens que transitam pela narrativa. De todas, a mais significante é a figura de Sylvia, uma amiga (e, às vezes, amante) de Glauco, que aparece na história enquanto colega de faculdade do narradorpersonagem e, posteriormente, volta como uma confidente. Obviamente, enquanto um texto que, na capa, se propõe "autobiográfico", as personagens trazidas na narrativa entrelaçam-se no imaginário do leitor como uma pessoa real, fora do contexto literário. É o caso de Sylvia, por exemplo. Por ser 
significativa na trama, a credibilidade de sua existência é efetiva e amarra o leitor na busca por uma realidade externa. Por e-mail, Mattoso informou-nos que ela é ficcional, sendo uma construção personificada de várias pessoas com descendência japonesa, que passaram pela vida do autor, fora da literatura.

Características nipônicas são valorizadas pelo narrador no Manual e em inúmeros sonetos, e, também, na vida real do autor - tendo em vista que seu companheiro, desde o período da cegueira total, é Akira Nishimura, também com descendência japonesa. A predileção pelos asiáticos é defendida no livro, principalmente pelo formato estético dos olhos. Para alguém que se tornaria cego, ter como elemento atrativo, além do pé, o formato dos olhos, é também uma percepção sensível denunciadora do conflito pessoal do autor-narradorpersonagem com sua condição de deficiente visual.

Outras personagens trazidas dão força e forma às fantasias recontadas por GM, servindo ao que ele chama de inspiração masturbatória e possibilidade literária. A relação da memória com episódios sexuais está intrínseca à figura construída do autor (persona literária). No livro, todas as reminiscências narradas são, ao final, reforçadas por momentos de solidão do autor-narradorpersonagem, porém, relembradas com prazer. Isso solidifica o desejo por ele sustentado, formulando fragmentos de sofrimento e dor com regozijo e abjeção.

As características etimológicas que iniciam cada capítulo podem ser lidas como uma forma de cientificar as escolhas de Glauco e reforçar a exploração direta entre o que é humano e o que permite o prazer humano. É também uma denúncia paródica ao cientificismo da época, cujas ideias necessitavam estar bem justificadas e legitimadas, dentro de um contexto reconhecidamente maniqueísta ${ }^{51}$.

De fato e notoriamente presente no texto, o processo de leitura foi 0 gatilho para GM. No Manual, referenciais literários são trazidos, desde revistas em quadrinhos a textos em língua inglesa, sobre o universo sadomasoquista e underground da época. Referência a filmes, biografias e autobiografias, livros psicanalíticos e a bíblia, também dão forma ao intertexto criado pelo escritor.

\footnotetext{
51 "Doutrina criada por Manes (século III), que se difundiu pelo Império romano e pelo Ocidente cristão... Mantém uma visão dualista radical, segundo a qual encontram-se no mundo as forças do bem ou da luz, e do mal ou da escuridão..." (MARCONDES e JAPIASSU, 1996, p.172)
} 
Inúmeros são os contextos artíticos que solidificam a representação imagética da figura do pé na vida do autor-narrador-personagem. De todas elas, a que mais configura esse gosto e inúmeras vezes é reforçada em entrevista é uma cena do filme Laranja Mecânica, de Stanley Kubrick (1928999). O filme, de título original $A$ Clockwork Orange, é uma adaptação do romance homônimo (1962) do escritor inglês Anthony Burgess (1917-1993). Para Glauco, a cena mais marcante e referencial ao seu gosto é a do protagonista Alex (fig. 38), quando é pisado e submetido a lamber as botas de um algoz. No livro, descreve Glauco:

Em Laranja mecânica (A clockwork orange), de Stanley Kubrick, o personagem central é o jovem delinqüente que, após passar pela robotizante lavagem cerebral da prisão, é testado diante duma seleta platéia, tendo que obedecer sem reagir a um agressor que o derruba, põe-lhe o pé sobre o rosto e ordena-lhe que lamba, "again and again". O close da língua sob a sola do sapato é uma das imagens mais excitantes que assisti. (MATTOSO, 2006, p. 19)

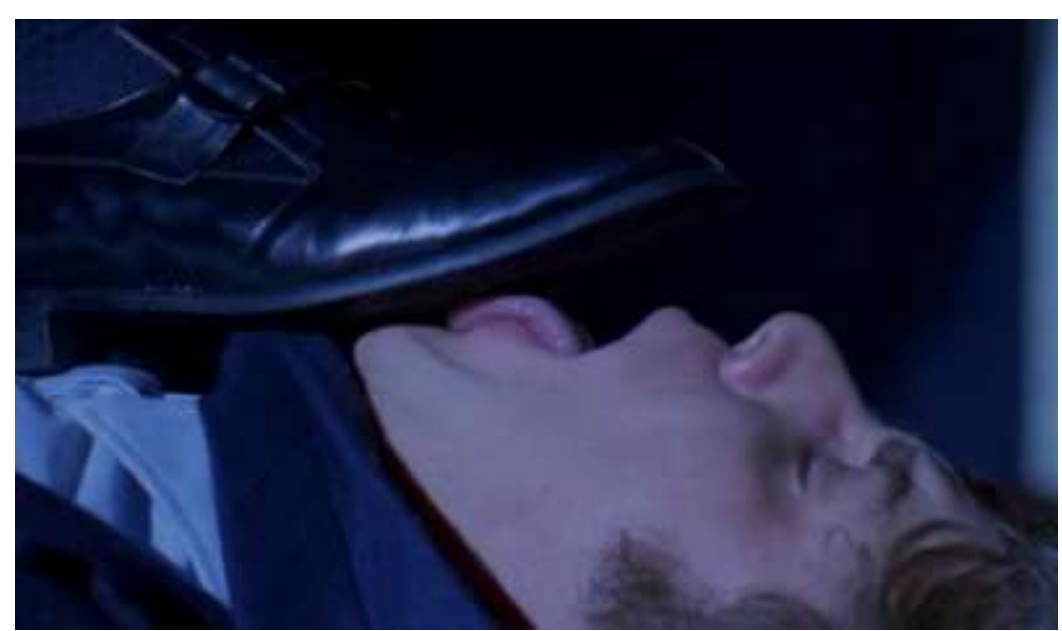

Fig. 38 - Alex, protagonista do filme Laranja mecânica, de Stanley Kubrik, lambendo a sola de um sapato, 1971. 


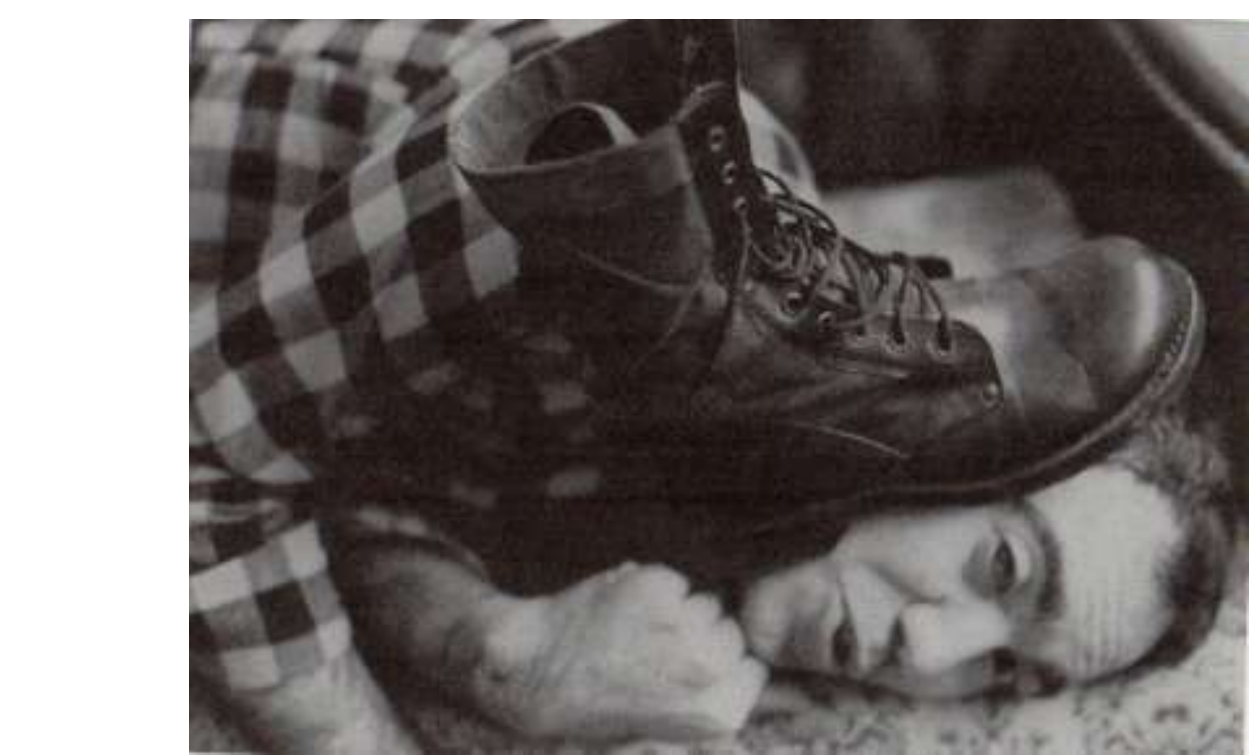

Fig. 39 - Glauco Mattoso, numa representação fetichista. Foto de Rubinho Chaves, 1977.

Não só Laranja Mecânica, mas outras imagens cinematográficas estão presentes em vários trechos do Manual, sequenciando os fatos e se fixando na mente daquele que em breve se tornaria cego. Escrito enquanto Glauco Mattoso ainda enxergava, o Manual é tecido pelas lembranças. Glauco chama sua memória de "memória de cego", em que muitas outras recordações vivas e coloridas, se sobrepõem cumulativamente em sua memória. (2006, p. 19). Essas lembranças permitem ao autor, por uma construção estética, converter 0 que é moralmente julgado como mal, em bem, indo ao encontro do que Hegel vai chamar de "remissão e distensão do espírito", cuja arte é mediadora e anuladora desses valores e conceitos a priori, desligando-se da obrigação com a verdadeira representação (HEGEL, 2001, p.29).

Essa distensão espiritual é revelada pelo movimento interno e externo que permeia a arte, buscando a solução do conflito gerado nas relações entre sujeito e ideia (da obra), não precisando, com isso, associar o objeto ao verdadeiro e universal. O compromisso da criação artística é a forma de romper com verdades e valores, principalmente àqueles jogados no contexto universal.

Na narrativa, o autor-narrador-personagem com glaucoma é natural de uma família pobre, nascido e criado em São Paulo, de maneira cuidadosa devido à deficiência visual. Glauco relembra sua infância e as descobertas sexuais a partir do contato com o "Inimiguinho" - amigo de Glauco descrito como seu iniciador sexual, aos cinco anos de idade. Ironicamente, o livro 
desconstrói a imagem da infância como lugar de pureza e inocência, rompendo com as descrições comuns da beleza e perfeição da infância, retratadas com frequência em textos românticos. A infância também é revelada, na narrativa, como espaço de humilhação e tortura, a partir da prática do bullying - "calejado pelas curras da infância, e desta vez os limites do nojo tavam lasseados mais que o suficiente (...)" (MATTOSO, 2006, p. 80).

Não só essa situação descontrói o universo do romance romântico, como também o espaço da paixão, da sexualidade e do sexo são ressignificados por Glauco Mattoso a partir de associações com gêneros e guetos, escolhas e gostos, transgressão e reafirmação identitária. Traçar o percurso do narrador como fetichista por pés masculinos, assumindo o gosto pela humilhação, é também uma forma de expor necessidades da condição humana, bem como a aparente solidão do autor-narrador-personagem, enquanto alguém que possui um gosto que julga diferente do da maioria.

É do humano refletir a própria dor e desgraça. No Manual, GM faz do autoescárnio um condicionante sério para a narrativa, cujo objetivo principal é distender a dor e o sofrimento causados pela sua condição cego. Do ponto de vista estético, essa escolha promove o texto do autor ao paradoxo de valores por meio de uma ironia fina, contrariando ideias de escolhas e comportamento, cobrados socialmente e culturalmente. A narrativa não permite um riso dilacerado, debochado, mas uma reflexão pela ironia ali contida, contrapondo o senso comum, tanto da recepção do texto literário como de gosto. O escárnio em Mattoso, como uma arma contemporânea de linguagem, é denunciador da conversão da desgraça pessoal em prazer pessoal. Está ligado à zombaria, ao ridículo, à sátira explicitamente crua. GM se autoescarnece o tempo todo, na narrativa, anulando os intempéries da condição da cegueira, de modo a provocar, denunciar e se fortalecer.

Para o autor-narrador-personagem, esse processo reverberado pela linguagem literária é esteticamente a forma de destituir um estado moral externo à obra, bem como de curar suas feridas, a partir da escolha linguística de um texto autoescarnecedor. Para Hegel, essa satisfação infinita do sujeito em sua representação por meio de elementos do humor permite ao artista a experiência de se sentir elevado pela própria contradição, justamente por 
anular o conflito da desgraça pessoal (HEGEL apud SUASSUNA, 2009, p. 9293).

A cena que traz a relação entre o prazer da brincadeira infantil com a sujeira e degradação, por ser transgressora, rompe com questões do invólucro imaginário do leitor quanto à figura da criança e é escolhida para representar, por toda a narrativa, a podolatria de Glauco.

Com os pés, então, foi uma festa. Descobri que a mesma parte do corpo, que ele usava pra me chutar a canela quando brigávamos, podia servir pra eu pôr a boca; (...) a parte que ele passava no pano de chão antes de entrar na sala encerada, servia pra passar na minha língua. Aquilo era fabuloso, porque parecia tão absurdo... e ao mesmo tempo não exigia tanto sacrifício. (...) Era a liberdade de experimentar aquilo que ninguém aprovaria. De provar o gosto do mijo, o cheiro do cu, o calor do hálito. (MATTOSO, 1986, p. 17)

Para Glauco, recapitular o que ele chama de "ritual de iniciação" é também uma forma de se indagar: "será que tudo aconteceu e foi como contei"(2006, p. 24)? Os limites entre realidade e ficção se tornam nebulosos, principalmente neste trecho presente na segunda edição, em que Mattoso afirma a imprecisão dos relatos narrados na primeira versão:

Os limites entre a realidade e a fantasia são imprecisos em qualquer tipo de memorialismo, e este livro não foge à regra. Nos sonetos que compus, já cego e quase cinquentão, acho que consigo capturar com maior fidelidade fatos escamoteados ou camuflados no texto original redigido nos anos 80 , mas mesmo assim há que se ressalvar 0 lembrete passado num deles, o "Cético": Não creia em tudo aquilo que está lendo. (MATTOSO, 2006, p. 24 - destaque nosso)

O mesmo trecho dialoga com poemas do JD, em que o leitor é deliberadamente tido como um tolo, quando crê fielmente naquilo que a escrita apresenta e que o autor articula. Ademais, essas imprecisões memorialísticas são também possibilidades imagéticas construídas pela figura do cego, na narrativa, em que traz à tona acontecimentos marcantes por meio de elementos visuais precisos, como o pé no rosto. Essa imagem vai se tornar, por todo texto, tendenciosa e manipuladora da personalidade de Glauco, cujas vontades sempre se voltarão à experiência vivida na infância e reinterpretada/associada a cada rememoração. 
Mattoso discorre sobre a memória como algo que, ao passo que engana e sempre é relembrada com imagens novas, também pode ser fixa e ficar "cravada", impossibilitando distorções e omissões (2006, p.24).

As referências de leitura são múltiplas, passando por Apollinaire, Sacher-Masoch, Luís da Câmara Cascudo, Drummond, Guido Mantega, Fernando Gabeira entre tantos outros de maior ou igual importância, e, em todas elas, o elemento dialógico mais significativo para a história do texto é a podolatria, a partir da visão do leitor Glauco Mattoso. Gilberto Freyre, Raduan Nassar, José de Alencar, Manuel Bandeira, por exemplo, são trazidos, na narrativa de Mattoso, como referências podólatras da literatura brasileira.

De forma a costurar a temática que permeia todo o texto, a podolatria é reverberada, também, pela tortura, possibilitando um referencial ainda maior quanto à temática fetichista, dialogada e representada, muitas vezes, por textos pós-ditatoriais.

\begin{abstract}
Transar o pé de alguém sugere a sujeição à cabeça dessa pessoa, moral e psicologicamente falando: o exercício de seu poder, a imposição de sua vontade, o domínio sobre o outro. Mas também sugere a sujeição ao seu corpo todo, no próprio sentido dos sentidos: a extremidade inferior representaria justamente o começo, as preliminares daquilo que vai se completar no momento e no local do orgasmo. Além disso, o ato de transar o pé extrapola as relações pessoais pra sugerir sujeição a instituições mitificadas, como a autoridade militar, a hegemonia política, a ascendência social ou a superioridade racial. (MATTOSO, 2006, p. 62)
\end{abstract}

O tema tortura é visto no romance como espetáculo, cujo autor-narradorpersonagem faz o papel de voyer para remontar na memória suas lembranças masoquistas do rosto pisado e do indivíduo quase cego, que é humilhado a todo instante, porque deseja a humilhação. As referências aos presos políticos durante $\circ \mathrm{Al}-5$ e a prática da tortura durante o Regime são múltiplas e inquietantes. Glauco incomoda mais ainda por narrá-las de maneira irônica, buscando das cenas retratadas construções de imagens prazerosas. O livro de Mattoso, embora já escrito em período de abertura política, é denunciador, pois como proposta intertextual, transita por inúmeras emergências dialógicas no contexto da escrita ditatorial. 
A sujeira, o suor e demais secreções do corpo são descritas, em diversos episódios, como representação da submissão de um em detrimento ao desejo do outro, reforçando o caráter desumanista enquanto recurso estético: "Lambi até que o gostinho do chulé se confundisse com o sabor da própria saliva". (MATTOSO, 2006, p. 180)

É também uma escolha para ironizar as formas de contágio de doenças sexualmente transmissíveis (vide a releitura da Glaucomix), pois, pelo pé, Glauco estaria livre delas, destituindo, também, o rótulo de "praga gay" dado ao vírus HIV na década de 1980 e comentada pela narrativa. As descrições sobre seu fetiche e a defesa dele, bem como o desejo pelo odor do chulé são, não só uma escolha, mas, no texto, uma legitimação dessa escolha, reforçada pelo intertexto.

$\mathrm{Na}$ obra, ao assumir uma diferença, bem como assumir desejos sexuais de maneira explícita, principalmente no terreno da homossexualidade, Mattoso rompe, pelo contexto da época, com as representações legitimadas de grupos sociais e com questões identitárias, morais e éticas, construídas fora do espaço literário. Mais do que isso, também desestabiliza o verossímil e poético da escrita, já que rompe com as fronteiras dos gêneros textuais e da relação entre fiç̧ão e realidade.

Ao praticar a ação de lamber pés sujos, calçados ou não, Glauco assume uma comunhão entre o prazer por meio da subserviência e dá, no livro, um conceito de liberdade próprio da narrativa, em que a escravidão, por oposição, é convertida em liberdade, justamente por se escolher ser escravo do prazer ao ser escravo do outro. Tornando-se uma escolha, é livre por natureza, haja vista que, previamente, passou pelo crível daquele que a optou.

A "massagem linguopedal", calcada a partir de noções da reflexologia, é proposta por Glauco a desconhecidos, via anúncio em panfleto por ele mesmo confeccionado, fornecendo dados para troca de correspondência, com intenção de avaliar antes de escolher seus "clientes". A correspondência é também uma paródia dos famosos correios sentimentais, comuns em revistas de públicos específicos, da década de 1980 e 1990, bem como da oferta de serviços terapêuticos e alternativos. GM, com o nome de "Gato Sapato" imprimido nos panfletos e cartas, decide converter seu desejo num benefício àquele que the permitisse a prática da lambida nos pés, calçados, com chulé e frieira, de 
preferência. Como maneira convincente, conseguiu, na narrativa, adeptos (homens, por escolha de Mattoso) para sua prática, sem fins lucrativos. Isso lhe permitiu um registro empírico da ação, corroborando para a elaboração do texto autoficcional.

Ao finalizar o Manual, especificamente a segunda edição, o autornarrador-personagem brinca com suas interferências, metatexto, gostos e referências literárias, e retoma o fetiche como um fator libertário do indivíduo que assume seu gosto e prazer. A experiência pós-cegueira reforça o fetiche por pés, numa miscigenação entre palavra e vivência, memória e literatura, em que a ambiguidade da infância é reconstruída por fragmentos visuais.

A desgraça pessoal, convertida e autoescarneceada em um processo lúdico do prazer, mantém a instância literária Glauco Mattoso viva, dentro e fora da literatura. Contribuindo para que a relação de efeito entre leitor e obra seja intencionada pela premissa da autobiografia, o texto da segunda edição é encerrado com data, 29 de junho de 2001, aniversário de 50 anos de Pedro José Ferreira da Silva. 
O capítulo anterior, cujos esforços maiores foram pela leitura do Manual do podólatra amador nos levou a pensar sobre que tipo de texto é esse e qual a sua intencionalidade enquanto obra pseudodidática. Mais do que isso, notase o destaque dado à narrativa memorialística do autor-narrador-personagem, que quer trazer publicamente aquilo que assume ter vivido privadamente. Esse sujeito, que assume para si questões dentro e fora do texto, não é só Glauco Mattoso, mas o é enquanto personagem.

A compreensão de um personagem de si mesmo é descomplicada no conceito latino de alter ego, em que o sujeito cria um "outro eu" como personalidade alternativa, para dar conta de questões múltiplas de modo mais seguro e confortável. Entretanto, o termo vai ganhar desdobramentos e aprofundados específicos na psicologia, como criação de uma outra personalidade, que vive paralelamente com a "identidade real". Como possibilidade psíquica do sujeito e calcada na complexidade das abordagens subjetivas do ser, o alter ego não só reduz nossa atividade aqui proposta ao conceito duplo de indivíduo, como pode se distanciar da criação artística enquanto terreno ocupado pela estética, pois tende anular a escolha do sujeito em desdobrar-se e a substitui pela necessidade resultante da dificuldade em se lidar com questões próprias, transferindo-as para uma outra personalidade. Dessa feita, para dar conta, mais adiante, da questão do nome 'Glauco Mattoso', é necessário compreender, não só o que seria esse desdobramento, mas por que a concepção de "outramento", fortalecido pela heteronímia, se constitui necessária na obra por ele construída e como esse outro é fundamentado num texto autoficcional - construção estética altamente eficaz para dar conta de um "personagem de si mesmo".

Justifica-se, enquanto análise estética, a necessidade de se trabalhar o Manual do podólatra amador pelo ponto de vista da autoficção, não pelos modismos acadêmicos das discussões teóricas atuais acerca do conceito, já 
discutido há algumas décadas na França. Mas por exigências do próprio texto de Mattoso, ambíguo, falseador de gêneros textuais e altamente melindroso quanto à narrativa pessoal, é que as discussões que sucedem esse breve introito de capítulo se pautaram. Não há como justificar esteticamente as escolhas de Mattoso sem compreender as linhas em que foram tecidas. A autoficção é, possivelmente, uma delas.

\title{
5.1 Premissas sobre autobiografia e autoficção
}

\begin{abstract}
"Autobiographie? Non, c'est un privilège réservé aux importants de ce monde, au soir de leur vie, et dans un beau style. Fiction, d'événements et de faits strictement réels; si l'on veut, autofiction, d'avoir confié le langage d'une aventure à l'aventure du langage, hors sagesse et hors syntaxe du roman, traditionnel ou nouveau. Recontres, fils des mots, alliterations, assonances, dissonances, écriture d'avant ou d'après literature, concrète, comme on dit musique. $\mathrm{Ou}$ encore, autofriction, patiemment onaniste, qui espère faire maintenant partager son plaisir." SERGE DOUBROVSKY, Fils, 1977
\end{abstract}

A palavra autoficção tem origem francesa, autofiction, cujo conceito nasce no romance Fils, de Serge Doubrovsky, publicado em 1977. O neologismo é decorrente da discussão empreendida no livro de Philippe Lejeune, Le pacto autobiographique (1975), rompendo com a ideia de pacto entre leitor e obra, firmado a partir de elementos considerados reais fora do texto literário, limitando e definindo o horizonte de expectativa do leitor.

Antes de buscar uma compreensão sobre autofiç̧ão, é preciso fazer um retorno às considerações de Lejeune acerca do conceito de autobiografia e suas implicações na literatura.

Le pacto autobiographique foi um dos primeiros grandes estudos sobre a escrita autobiográfica. Lejeune debruçou-se sobre a escrita de si e os elementos textuais que compõem esse gênero, até então, considerado uma sub-literatura. Na primeira edição, diversas críticas foram empreendidas ao 
texto do teórico, principalmente quanto à sua categorização em relação ao pacto firmado e a rigidez de uma leitura direcionada por limitadores, que reduziam as possibilidades de interpretação e definiam "verdades" dentro e fora do texto literário, marcados pela presença do eu-autor.

A escrita autobiográfica (e também autoficcional) não é algo novo. Desde textos filosóficos e religiosos, como as Confissões de Santo Agostinho às Confissões de Rousseau, reflexões sobre o "eu" estiveram presentes em todos os contextos da linguagem e da história da escrita. O próprio Lejeune deixa claro em seu texto que, não há nada de novo em se retornar ao conceito de autobiografia, embora as discussões acadêmicas sobre esse tema ainda pareciam, naquele momento, mornas e, talvez, esquecidas por parte da crítica literária, que sempre viu nesse tipo de construção textual um único espaço de exploração, em que a proposta estava em narrar fatos do autor, cujo gênero não se enquadrava no espaço da poética e da criação.

Embora a autobiografia tenha sido relegada, principalmente, pelos estudos estruturalistas, é nesse tipo de escrita, permeada entre a ficção e realidade, que os novos estudos acadêmicos da literatura vão se debruçar no final do século XX e início do XXI.

O texto, revisitado e repensado por Lejeune em sua segunda edição, em 1996, (publicada em português em 2008), contempla um novo olhar acerca do pacto defendido na primeira edição e marca um momento dos estudos literários acerca de narrativas do eu e suas possibilidades em torno de aspectos que transitam entre ficção e realidade.

Segundo Lejeune (2008, p. 18-19), a identidade do autor-narradorpersonagem, dentro de um texto autobiográfico, é marcada, não só pelo emprego do pronome "eu", em que promove no leitor uma zona de precisão interpretativa, mascarada pelas pessoas gramaticais que evocam um efeito em comum, mas, também, causam um efeito que assume uma sensação de veracidade daquilo que está sendo lido. O pacto torna-se então inevitável, na medida em que elementos paratextuais são identificados dentro do texto, de forma a credibilizar o que está escrito a partir do diálogo entre vida e obra do autor-narrador-personagem.

Em meio a essa discussão, Doubrovsky propõe um novo olhar para escrita de si, a partir do que ele vem a chamar de "autoficção". Cunhar o termo 
e defini-lo dentro de um romance, prática de escrita já legitimada como fictícia, marca a ironia do autor em não se enquadrar nos conceitos trazidos por Lejeune, propondo-se, por meio de um discurso, aparentemente despretensioso, a dificuldade em saber os limites do pacto entre leitor e obra e de como o terreno entre ficção e realidade, no romance, é mais arenoso do que se pode prever a crítica.

Obviamente que os dois conceitos, tanto o de autobiografia, proposto por Lejeune, quanto o de autoficção, trazido por Doubrovsky promoveram novos olhares para as narrativas do eu, abrindo espaço para o trânsito livre de debates múltiplos em torno da ficção e realidade na literatura.

Discussões sobre os efeitos da homonímia e demais denunciadores de um texto que, já no título, se propõe autobiográfico, empreenderam olhares diversos em torno do espaço de criação ocupado pelo texto autobiográfico e de como as fronteiras podem ser híbridas e manipuladas por uma estética criada por aquele que escreve o texto.

No Brasil, as discussões acerca, principalmente, da autoficção, começam a ganhar espaço, na crítica, bom tempo depois de seu advento na França. Com uma explosão de textos memorialísticos, em que a presença da primeira pessoa no texto passa a ser muito recorrente, a literatura brasileira contemporânea marca um período definido pela exploração excessiva da escrita de si, principalmente influenciada pelos anos de Ditadura Militar, agregando característica memorialística, testemunhal e autobiográfica.

Conforme trazido anteriormente, as restrições impostas durante o regime foram crucias para uma nova configuração da escrita ficcional nacional, a partir de relatos daqueles que vivenciaram os anos de chumbo, bem como das explosões estéticas oriundas do movimento Modernista de 1922. O final do século XX traz também uma arte carregada de rótulos 'pós', em que uma ideia de hibridação e intertexto, principalmente na literatura, ultrapassa os limites dos gêneros textuais e transgride valores estéticos ainda modernos. De acordo com Ítalo Moriconi,

Do ponto de vista cultural mais amplo, o fim do século $X X$ é póscanônico, pós-vanguardista, pós-modernista. Na poesia brasileira, é marginal e pós-marginal, pós-moderno e pós-modernista. Vemos logo que o debate intelectual no período pautou-se por rótulos em "pós", prefixo ubíquo. O fim do século foi para lá de depois. E esse 
vivenciar-se como póstero de si próprio engendrou uma terminologia, muitas vezes polêmica, outras intrincada. Um exemplo: as expressões "pós-moderno" e "pós-modernista" não são rigorosamente sinônimas, embora estritamente relacionadas. Pós-moderno diz respeito ao contexto cultural globalizado pop-midiático. Já pósmodernismo é termo de periodização artística e literária. É o que vem depois do modernismo. Entre pós-modernismo e modernismo, as relações são complexas, de continuidade e descontinuidade, permanência e deslocamento. O modernismo é uma totalidade histórica. O pós-modernismo, um conjunto aberto de traços heterogêneos. ${ }^{52}$

As discussões acerca da pós-modernidade e suas implicações na arte e na literatura são atuais e contestáveis para muitos autores, especialmente na área antropológica. $\mathrm{Na}$ crítica literária, dificilmente se encontrará qualquer discussão sem que os estudos de Linda Hutcheon, em seu livro $A$ poética do pós-modernismo (1991), estejam presentes. De fato, as percepções trazidas por Hutcheon - embora em nenhum momento definidoras de um período abordam questões que vão além do rótulo de pós-modernismo e inauguram discussões da escrita limiar entre uma ideia de modernidade e pósmodernidade, de caráter relevante para os novos rumos da criação literária.

Para a autora, o elemento-chave da escrita contemporânea parte de uma nova configuração da escrita em prosa: a metaficção historiográfica. A escrita narrativa, principalmente o romance, busca na história sentidos variados para a composição do texto, reinventando a escrita do romance histórico, bem como dialogando com questões acerca da cultura, de identidade, da memória e, principalmente, de uma história oficial.

Dentro da configuração da metaficção historiográfica transitam características peculiares, como a paródia, a intertextualidade, a descontinuidade, o deslocamento, a indeterminação, e, em destaque, a autorreferencialidade. Para Hutcheon, o sujeito se faz presente na contemporaneidade por ser um sujeito autorreflexivo e subversivo, cuja intenção é atuar dentro da história e não fora dela (1991, p. 205).

A subjetividade na arte, bem como a presença do 'eu' criador, revela, no século $X X$, uma geração em que a necessidade de formular enunciados que

\footnotetext{
52 "A problemática do pós-modernismo na literatura brasileira", texto disponível em: <http://www.filologia.org.br/abf/volume3/numero1/02.htm>
} 
dialogam com seu estar no mundo compreende um sujeito que assume uma heterogeneidade e os processos múltiplos das identidades em transição.

Diante da problemática trazida aqui sobre as discussões teóricas acerca da escrita do eu, a autoficção parece um movimento inevitável da literatura, principalmente em consonância com os reflexos de um período de linguagens e diálogos múltiplos.

Em Ensaios sobre a autoficção (2014), organizado por Jovita Noronha, é possível compreender o percurso das discussões em torno do neologismo, bem como as pluralidades de teorias que surgiram num desdobramento de reflexões sobre autobiografia e autoficção. Com uma reunião de textos de pesquisadores franceses sobre as narrativas do eu, Noronha permite aos leitores brasileiros a possibilidade de se ingressar nas discussões empreendidas até o momento sobre os rumos da autoficção.

Doubrovsky, ao cunhar o termo, não fecha a definição - conforme consta na epígrafe - e chama de autofricção como forma de dar espaço a outros pontos de contato da relação entre realidade e ficção dentro da escrita literária e de si.

Dessa discussão, novos pesquisadores ampliaram o termo e conduziram pontos de vista preciosos em torno das possibilidades da ficcionalização de si dentro da literatura. Vincent Colonna, em Autofiction \& autres mythomanies littéraires (2004), elenca tipologias de autoficção que vão além do termo proposto por Doubrovsky, em que a homonímia pode ou não existir, embora o texto transite entre ficção e possibilidades de uma realidade narrada pelo autor. Para Colonna, a autoficção é a ficcionalização de si, em que, muitas vezes, permite uma "mitomania literária", ou seja, construção de si como mito, e pode ser identificada por, pelo menos, quatro tipos diferentes: autoficção fantástica; autoficção biográfica; autoficção especular e autoficção intrusiva.

Eurídice Figueiredo, em Mulheres no espelho: autobiografia, ficção e autoficção (2013), traz as diferenças entre os quatro tipos de autoficção apontados por Colonna: Ela difere cada parte: a) Autoficção fantástica: em que "o escritor é protagonista, mas a história contada é fantástica, portanto o leitor lê com distanciamento, já que sabe se tratar de uma fantasia" (FIGUEIREDO, 2013, p. 64); b) Autoficção biográfica: espaço em que Colonna identifica a construção da minotamia literária, é momento em que "o 
escritor está no centro da intriga e a história contada se oferece ao leitor como sendo verdadeira, ou, ao menos, plausível, verossímel." (Idem, p. 64); c) Autoficção especular: "o escritor está presente, porém não é o protagonista da história... na autoficção especular, o autor aparece de forma miniaturizada, com seu nome próprio." (Idem, p. 64); d) Autoficção intrusiva: em que "o escritor está à margem da intriga, porém, através do narrador, ele comenta a ação ou faz uma digressão". (Idem, p.65)

Em geral, para Colonna, a marca da autobiografia é, simplesmente, a característica de romance híbrido, que se mistura com outros tipos de escrita; que não se define, porém, está riscada por traços da escrita contemporânea. (COLLONA, 2004)

Pautados nessa discussão e pensando na construção do Manual como condução de uma "mitomania" elaborada pela estética, daremos início à análise da narrativa de Glauco Mattoso, como forma de compreender a construção desse eu-ficcional envolto por definições autobiográficas elaboradas por artifícios da linguagem literária.

\subsection{Manual do podólatra amador : um caso de autoficção}

Não somos os primeiros a relacionar a escrita glaucomattosiana com aspectos da autoficção. Apesar dos estudos mais extensos sobre o Manual do podólatra amador, até o momento, partirem das discussões do nosso grupo, Rafaella Lemos, com sua dissertação Glauco Mattoso: Escrita e transgressão ${ }^{53}$, aponta brevemente a relação da escrita de GM com características da autoficção, a partir de análise sobre alguns sonetos e heterônimos.

Nas nossas discussões, tanto a autoficção, quanto a criação heteronímica são intrínsecas na obra de Mattoso, pois confundem e intensificam as possibilidades de vieses interpretativos, ao passo que gera um

\footnotetext{
${ }^{53}$ Dissertação defendida na UERJ, em 2010, sob orientação de Ítalo Moriconi.
} 
pacto entre leitor e obra, limitando o processo de fruição quando se crê naquilo que se está lendo e se acredita na identidade defendida pelo texto literário.

Escrever sobre si é colocar-se diante de objetos, tanto de lembrança como de construção, observação, fantasia e análise e representar isso por meio de uma linguagem, como uma ação de auto(re)conhecimento. A presença do eu na obra de Mattoso, conduzida por esses objetos de lembrança e literatura, é um reforço identitário da persona por ele criada: o glaucomatoso Glauco Mattoso.

A autoficção é compreendida como a autobiografia pós-moderna, em que a figura do autor e a escrita de si não mais estão em busca de uma verdade extraliterária ou um registro de vida, mas busca por possibilidades, por meio da escrita, de compreensão sobre questões em torno de si mesmo e do que esse eu representa no instante da feitura do texto.

A escrita com elementos autobiográficos é também uma forma estética de retomar e valorizar fatos da memória, tanto individual como coletiva. Ela pode estar presente em diversos gêneros, de forma metalinguística, apresentando-se na escrita autobiográfica, confessional, testemunhal, autoficcional, etc.. Sua definição atual é plural, já que permite elementos do individual e privado, confessados, narrados ou criados pelo processo dialético entre ficção e realidade.

Para Lejeune (2008), o memorialístico é diferente do gênero autobiográfico, pois o primeiro pode estar alheio ao autor-narradorpersonagem. Entretanto, ao olhar a obra glaucomattosina, nota-se que a escrita de si busca por elementos que são reconstruídos pela memória. Levando em consideração que a construção literária é uma atividade artística da razão sensível, conforme nos propõe Hegel (2009), a criação a partir da escrita de si é um processo meticuloso, que visa um retorno consciente do eu sobre aquilo que se quer expressar artisticamente em torno de si mesmo. $O$ retorno parte, também, da relação entre o eu e seu passado. No caso de Glauco Mattoso, um passado pessoal de cegueira e fetiche misturado ao passado literário daquilo que leu. Há, no Manual, a necessidade de GM em retomar um fato ou acontecimento, imortalizando e reconstruindo na narrativa, percepções fixas de determinado momento. Esses momentos narrados, independentemente de sua veracidade quanto à "vida real" do autor, são 
definidores de uma identidade externa ao texto e eternizados por uma obra insistentemente representada pela figura do eu e articulada esteticamente como autobiográfica.

A presença do autor nas obras glaucomattosianas nos conduz a visitar as discussões de Michel Foucault, em "O que é um autor?" (2013) e Roland Barthes, em $A$ morte do autor (2004). De fato, os objetivos abordados pelos dois autores acarretam diferenças, contudo, interessantes para trilharmos um caminho de compreensão da obra de Mattoso.

Barthes decreta a morte do autor como instância na literatura, desconstruindo a figura mitológica do sujeito autor, criada ainda na modernidade.

O autor é uma personagem moderna, produzida sem dúvida pela nossa sociedade, na medida em que, ao terminar a idade Média, com o empirismo inglês, o racionalismo francês e a fé pessoal da Reforma, ela descobriu o prestigio pessoal do indivíduo, ou como se diz mais nobremente, da "pessoa humana". (BARTHES, 2004, p. 1)

Michel Foucault, por sua vez, transita pelo terreno do discurso, em que a autoria é fruto de um enunciado emitido por um enunciador, cujo contexto intervém nas construções interpretativas internas da obra, valendo-se de percepções históricas ligadas, mais ao discurso, que ao sujeito que discursa (FOUCAULT: 2013).

Barthes, em especial, incomodava-se com a forma como os autores eram compreendidos a partir do peso de suas biografias e autobiografias, direcionando a relação do leitor com o texto por meio da figura do autor, posição fruto da crítica estruturalista.

O que, de fato, nos auxilia na compreensão da presença do 'eu' no Manual são os cuidados nas considerações de Barthes em torno dos limites criados pela figura do autor no viés interpretativo do leitor. As confidências de Glauco Mattoso: seu fetiche, sua cegueira e sua relação pessoal com a literatura não podem gerar, para esta pesquisa, um movimento de fora para dentro do texto, mas da narrativa para os elementos externos e contextuais, ligados à construção estética do autor. Como comenta Barthes (2004), esse 'eu' que escreve é um eu frágil, que pode se desfazer perante a escrita e 
interpretação do leitor; também é um eu cujo discurso é neutro, do ponto de vista de que não há necessidade de saber o que há por traz daquele enunciador senão seu discurso.

Isso nos retorna aos comentários empreendidos por Ronaldo Costa Fernandes ao falar do leitor real e virtual. O primeiro, aquele o qual se dirige o narrador pode ser também um leitor ficcional, que é conduzido pelas amarras construídas pelo autor-narrador-personagem e firma-se numa relação pactualmente formal com as nuanças das escritas e suas verdades intrínsecas. (FERNANDES, 1996, p.8)

Michel Foucault, ao permitir um olhar sobre o discurso daquele que escreve, faz apontamentos divergentes do que foi proposto por Barthes, de modo a dar espaço àquele que cria e narra ao mesmo tempo. Pensar a problemática do autor é buscar compreender seu desempenho e função por trás do discurso emitido no texto, cuja relação entre autor e obra acontece no momento da criação do texto sobre elementos de 'eu'. As discussões de Foucault partem de seu extenso estudo sobre o sujeito moderno e o cuidado e compreensão de si ao longo dos séculos. Para ele, a relevância está no discurso criado e não, necessariamente, no sujeito que cria - já que o discurso é articulado, modificado e, dialogicamente, amplia as possibilidades de compreensão e interpretação por meio dos múltiplos sentidos contidos no texto (FOUCAULT, 2013).

Ao olhar para obra de Glauco Mattoso, imergimo-nos no seu contexto "autobiográfico", que gera, pela leitura, um movimento linear em torno da figura do autor e sua condição pessoal de vida. Perigosamente, isso leva o leitor à relação intrínseca da vida do autor com a obra por ele escrita, pois, diz Fernandes:

A relação inicial do leitor é sempre de humildade e de "silêncio". O leitor real ouvirá a versão do narrador sobre uma história que ele, leitor, nem sabe qual será. Mas há um acordo tácito entre narrador e leitor de que o primeiro entreterá o segundo, informará sobre pessoas, fatos e coisas que o leitor desconhece ou, se conhece, não conhece a versão do narrador. A versão do narrador é dada pelo ponto de vista, pela maneira como conta e pelo acontecimento que tem a da história. (FERNANDES, 1996, p. 9) 
Um leitor humilde, nas palavras de Fernandes, é atento ao que pode encontrar no texto, mas deixa de lado veleidades interpretativas ou a exigência de ir além do discurso promovido por aquele que narra.

De fato, o Manual do podólatra amador, anunciado por Mattoso, na época, como um texto com forte característica autobiográfica, cujo rótulo foi endossado pela crítica, permitiu uma construção extranarrativa sobre a figura do autor e sua relação pessoal com seus escritos, conduzidos por elementos confessionais, contidos nesta obra e sustentados em muitos sonetos, todos reforçados pela homonímia. A relação do autor com a figura do pé, discorrida por toda a narrativa, é conduzida por uma linguagem poderosa, cujo narradorenunciador, pensando em Foucault, de nome Glauco, firma com o leitor o contrato comentado por Lejeune, direcionando o texto a uma leitura em busca de elementos críveis - discussão empreendida neste trabalho, discutida mais adiante.

Podemos afirmar que o Manual do podólatra amador é uma autoficção? Pensando em Doubrovsky e em sua definição, bem como na ampliação do termo a partir de Colonna, é possível identificar o principal elemento autoficcional defendido pelo primeiro: a homonímia (Glauco Mattoso, nome do autor, do narrador e do personagem principal) sustentada por um discurso de intertextos, paródias e memórias alteradas por duas publicações distintas. Não nos importa se essa afirmação é precisa ou não. O que contempla nossos anseios, por hora, é a compreensão desses elementos, que se propõem autoficcionais e como eles atuam na literatura enquanto escolhas estéticas. Daí a necessidade de recorrer à homonímia.

Glauco Mattoso é o nome que Pedro José Ferreira da Silva cunhou para si enquanto escritor, a partir do seu primeiro poema, datado de 1974, publicado em 1977 no JD. O "Kaleidoscopio", com fortes características de autorreferência, corrobora para a construção da figura do poeta cego acometido pelo glaucoma.

Relendo cartas com olho unico.

Delenda Carthago com olho punico.

Lenda escripta com olho runico.

Lente elliptica com olho conico.

Mente espirita com olho cynico.

Demente hysterica com olho clinico. 
Semente hermetica com olho cyclico.

Serpente heretica com olho biblico.

Sentença enclitica com olho obliquo.

Substancia lithica com olho liquido.

Sciencia critica com olho logico.

Verdecencia cryptica com olho glauco.

Experiencia optica com olho cego ${ }^{54}$

(MATTOSO, 2001, p.12)

A cegueira é trazida como nome do autor após a primeira publicação e divulgação do poema; Mattoso cria a persona a partir de várias relações entre doença e literatura (glaucoma e Gregório de Matos), cuja identidade é conduzida por uma construção estética do eu, reforçada pela narrativa Manual do podólatra amador.

O discurso sadomasoquista explorado no texto, sustentado por uma relação escarnecedora com a tortura e o sofrimento, também parte de uma construção literária, em que o eu por trás dessa voz enuncia um ponto de vista em torno de questões da condição humana, que vão além das reflexões pessoais, caindo no contexto universal.

Seguindo o livro por sua ordem cronológica, Glauco não é identificado na infância com o sobrenome Mattoso, permitindo compreender que o narrador (no livro) nasceu Glauco e só se tornou Mattoso a partir da sua inserção e reconhecimento no espaço literário. Também não é Pedro José (aliás, esse nome não é mencionado em nenhum momento no Manual), de modo a fortalecer a primeira percepção de homonímia em relação ao nome Glauco Mattoso, porém, fomentador da ideia de que Glauco Mattoso é um heterônimo, esteticamente construído pelo ortônimo Pedro José Ferreira da Silva e fomentado por uma vasta obra literária.

No decorrer da narrativa, vários indícios endossam a compreensão de que o Manual é uma autofiç̧ão. A forma como o autor lida com elementos da memória de sua infância, revistados pelos vieses fetichista e masoquista, também contribuem para uma elaboração tendenciosa, dentro do princípio de que, sua rememoração parte senão de uma condição defendida por uma estética pessoal, a da podolatria.

O texto de Mattoso é intertextual, referencial e dialógico. Conduzido por

\footnotetext{
${ }^{54}$ A ortografia segue conforme a escrita no JD.
} 
discursos que sustentam suas lembranças, as amarras entre ficção e realidade são traçadas por personagens, muitos deles literários, que, de alguma forma, vivenciaram aquilo que o autor-narrador-personagem também vivenciou. Mais do que uma relação com personagens, Mattoso firma uma relação com os autores por ele citado no Manual, cuja escrita é tendenciosamente descrita por ele como autores simpatizantes da podolatria. A figura do autor é reforçada pela presença da figura de outros autores, muitos canonizados pela crítica.

A forma como Mattoso busca a verossimilhança na sua construção estética-narrativa denuncia sua profunda relação com a ficção por meio da arte e da literatura, fazendo dele um Dom Quixote, porém, pessimista, masoquista e maldito - usando aqui alguns dos principais adjetivos calcados para sua escrita.

A reescritura e publicação da narrativa vinte anos depois, com alterações e um capítulo acrescentado, também é um elemento que confirma como a memória conduzida no Manual é passível de uma reinterpretação crítica. Abaixo, um parágrafo adicionado somente à segunda edição, em que o autor permite a compreensão de que muitas das histórias contadas no texto não são necessariamente verídicas, mas construídas a partir do movimento criado entre a pessoa que escreve e vive a história com a figura que vivencia e articula essas vivências com ficção literária.

\footnotetext{
Confesso mais: falei que estive naquele camburão por solidariedade pra com as fraternas bocas estupradas, das quais ouvi aquela história que (asseguram elas) é rigorosamente verídica. Nunca duvidei, até porque disso dependia muita bronha. Prefiro continuar acreditando que escapei daquilo por pura loteria. Até hoje, aliás, não ganhei sequer uma rifa de peão de portaria de prédio... (MATTOSO, 2006, p. 111)
}

Esse trecho vem logo após a descrição narrada como acontecimento real na vida de Glauco, em que foi preso pela polícia, junto de outros transeuntes, e foi obrigado a fazer o que ele chama no livro de "prece comunitária" e "chupetinha" nos guardas. Ao reescrever, Mattoso confessa que ele, de fato, não vivenciou aquilo, mas ouviu sobre, embaralhando a "realidade" com memória e ficção e tornando instável sua estética pautada em descrições de tortura e prisão. 
Ainda sobre o mesmo trecho, mais um indicativo de retorno ao inverídico pode ser compreendido a partir da leitura deste outro parágrafo:

Bem, houve sim, algo que ficou nítido na memória, apesar do cagaço; o cheiro das picas policiais. Fediam fartamente, e a recordação daquele fartum me confortou muitas noites, ainda que descontado o exagero de quem detalhou o pormenor olfativo. (MATTOSO, 2006, p. 122)

Mattoso confunde o leitor ao dizer que se lembra do "cheiro das picas", divergindo do que, em onze páginas atrás, ele afirmava não ter vivenciado, mas ouvido sobre o acontecimento, confirmando uma construção ficcional a partir de um episódio verossímil, porém, não vivenciado. Entre as páginas $111 \mathrm{e}$ 122 (2006), há uma inserção de intertexto, feita na segunda edição, rompendo com uma leitura linear do fato narrado com os policiais, que é retomado depois, porém, contradito por aquele que narra.

Na página 41 da primeira edição do Manual, Mattoso conta sua primeira relação sexual homossexual com o personagem Melchiades - considerado na narrativa, uma das grandes paixões do autor-narrador-personagem:

Antes que alguém pense que o protagonistão aqui conseguiu ficar, belo e faceiro, por coma da carne seca \& por baixo da sola molhada, vamos desmoronar logo o castelinho. Pra começo de conversa, nunca cheguei a pôr o beiço no pé de Melchiades. Trepamos muito, é verdade, e aprendi praticamente tudo com ele. Mas a coisa sempre começava de cima pra baixo, no beijo de língua, pra depois descer até o pau dele e terminar com meu cu penetrado, muita saliva lubrificando e a boca seca do Glauquinho engolindo a dor anal sem gemer.

Foi assim quase todo fim de semana, durante meses. (MATTOSO, 1986, p. 41 - destaque nosso)

Na segunda edição, o trecho é reescrito da seguinte forma:

Antes que alguém pense que o protagonistão aqui conseguiu ficar, belo e faceiro, por coma da carne seca \& por baixo da sola molhada, vamos desmoronar logo o castelinho. Pra começo de conversa, nunca cheguei a pôr o beiço no pé de Melchiades. Trepamos muito, é verdade, e aprendi praticamente tudo com ele. Mas a coisa sempre começava de cima pra baixo, no beijo de língua, pra depois descer até o pau dele e terminar com meu cu penetrado, muita saliva lubrificando e a boca seca do Glauquinho engolindo a dor anal sem gemer. Hoje já me pergunto se fui mesmo pra cama com meu ídolo, ou se só fiz cu doce pras cantadas dele. $O$ pior é que posso nem sequer tê-lo conhecido... Mas acho que havia algo de verdadeiro, ou pelo menos de verídico ou de verossímil, na 
minha dor anal, pois data já daquela época a prisão de ventre que literalmente me enfeza na maturidade... (MATTOSO, 2006, p. 59 - destaque nosso)

Notoriamente, a segunda edição foi determinante para reforçar a ideia de um texto autoficcional, embora a primeira já apontasse elementos transitórios entre a realidade e a ficção ali narrada:

\begin{abstract}
Como o leitor terá notado, tais contos nada mais eram que uma transposição de minhas experiências para um plano ligeiramente mais fantástico. Coisa que agora até se afigura supérflua, em face deste livro onde estou relatando tudo em proporções exatas. (MATTOSO, 1986, p. 120)
\end{abstract}

Ao trazer contos e trechos de novelas com teor sadomasoquista, Glauco se defende quanto à relação feita aos textos lidos com o que é narrado no Manual, mas se contradiz ao afirmar que os relatos são trazidos em proporções reais. Ora, proporção é um elemento associativo. Ali, Glauco compara suas experiências com a ficção, mas afirma se posicionar numa categoria mais fantasiosa, o que, de fato, distancia os fatos narrados de uma realidade externa à obra, tornando-se logicamente desproporcional.

Esse trecho também é uma forma estética de criar, entre leitor e texto, o pacto comentado por Lejeune e sustentado pelos elementos que definiam o texto como autobiográfico. Entretanto, para o leitor-atento e com acesso à segunda edição, o pacto é facilmente rompido e dialoga com muito mais propriedade à ideia de autoficção, desconsiderando as primeiras afirmações de que o Manual é a autobiografia de Glauco Mattoso.

Enquanto o escritor é pivô de seu texto autoficcional, de alguma forma ele conduz a uma interpretação de realidade externa ao texto, haja vista que os dados descritos são sempre construídos com uma linguagem que influencia e reforça essa interpretação. Desde palavras como "verdade" e "realidade", a verbos conjugados no pretérito perfeito, como "aconteceu", "vivi", "senti", também são recursos semânticos fortificadores da realidade construída em torno do texto autoficcioinal de Glauco Mattoso. Com muitas afirmações categóricas de que aquilo é uma "verdade absoluta", o Manual endossa ainda 
mais a "veracidade" capturada pelo leitor.

Quando o autor-narrador-personagem descreve a prática da massagem linguopedal feita em desconhecidos, ele reforça características verossímeis, principalmente por afirmar que precisou colher "dados verídicos" para a feitura do texto.

\begin{abstract}
Desse modo, um outro ponto positivo foi que, no plano pessoal, eu satisfiz meus propósitos. Aliás, obtive três tipos de resultado. $\mathrm{O}$ primeiro, pondo em prática minha tara com pessoas de fora do gueto guei. $O$ segundo, colhendo material verídico para este livro. $O$ terceiro foi uma coisa que eu não previa: acabei produzindo involuntariamente um lance poético/factual, conhecido como "intervenção urbana", "ruído visual", "estática estética", ou coisa que o valha. (MATTOSO, 2006, p. 164 - destaque nosso)
\end{abstract}

Ademais, a narrativa apresenta um reforço entre o que foi vivido com aquilo que o autor é hoje, numa forma de reafirmar a identidade do sujeito que conta a história com a história por ele contada.

\begin{abstract}
Me autobiografar parecia, à primeira vista, uma puta tarefa de fôlego, pois eu achava muito ambicioso fazer um romance, e muito pretensioso um livro de memórias. Só me dispus a isso quando percebi que a fórmula tava bem mais aquém: bastava ficar em torno daquilo que eu havia lido \& feito com relação aos pés. Já que nesse terreno a literatura é curta e minha experiência larga, tudo o que eu passasse pro papel serial lucro. Sem o peso de compromissos mais genéricos com a Ficção ou a Memorialística, foi fácil \& rápido produzir este livro. Que nem fazer um gol de pênalti, bater num cara marrado, empurrar um cego em ladeira, tirar doce da boca de criança ou gozar tocando uma punheta. (MATTOSO, 2006, p. 162)
\end{abstract}

Como confirmador dessa percepção, basta observar no texto os inúmeros diálogos de vivências podólatras com textos literários que autor também considera podólatras. Isso vai se repetir quanto ao comportamento masoquista: narra um episódio masoquista e traz uma referência literária considerada por ele masoquista; também é perceptível quanto à tortura: narra episódios de tortura, como um voyer, e traz narrativas pós-regime e pós-guerra, de modo a dialogar diretamente com tema por ele descrito, justificando sua transgressão ao colocar a dor no terreno do desejo sexual.

Em Mattoso, a subjetividade do fetiche é materializada em linguagem confessional, que gera expectativa de verdade e alimenta a figura do autor 
como um sujeito sincero. Glauco reivindica a imagem de um escritor logrado pelo depoimento pessoal e pela exploração de si, construindo aquilo que Colonna vai chamar de "mythologie d'écrivains", em que o artista explora a imagem lendária do personagem, em que explicações e justificativas são construídas, envolvendo a formação e constituição desse personagem, tornando-o crível (COLONNA, 2004, p. 98).

A leitura do Manual por esse viés nos conduz a pensar a identidade sustentada em todo texto. Quem é esse sujeito que narra?

\subsection{Personificação da cegueira como processo identitário heteronímico}

Ao cego, a luz é negra; o escuro, níveo. Ao ser fantasmagórico, a agonia é ver que pode entrar na cova fria e dela sair sem que um olho crive-o.

Soneto Acareado [567], Glauco Mattoso

Ao pensar em identidade no Manual do podólatra amador como construção heteronímica, há de se trazer a cegueira como um dos principais denunciadores da formação do "eu-Mattoso". A cegueira possui um espaço determinante, não só na figura do Pedro José, mas desse 'eu' narrado no Manual e confessado em sonetos, glosas, contos e crônicas. Ao separarmos, buscamos uma visão mais permissiva no que tange à figura literária que conta a sua desgraça.

Refletindo a perda da visão como definidor da criação literária de Mattoso e como ela pode ser compreendida, do ponto de vista da leitura do texto autoficcional àquilo que associamos com os elementos extratextuais da figura do autor, procuramos traçar um caminho para se chegar ao processo heteronímico por ele construído.

Compreende-se que a heteronímia, em GM, é proveniente de um sistema semântico que personifica a doença que o acometeu, o glaucoma, possibilitando, discursivamente, a (re)criação de si. 
Em diversas culturas (não apenas as primitivas, como dizia Quintana) a figura do poeta se confundia com a do bobo da corte, mixto de palhaço, cantor e contador de anecdotas. Quando Sansão, ja indefeso e cegado pelos philisteus, foi levado a exhibir-se nos festejos publicos, ficou explicito que deveria "brincar" para divertir a platéa. Ou seja: expor-se ao ridiculo pela propria cegueira. Si a desgraça alheia pode ser um comico espectaculo, tambem pode inspirar orgasticas $e$ orgiacas phantasias. Pensemos no sadomasochismo como fertil palco para papeis e trajes typicos. Como numa bacchanal carnavalesca, cada participante personifica uma tara ou um fetiche, todos devidamente vestidos... ou despidos. Ao couro da bota sadica corresponde o couro da venda masochista. Ao chicote do dominador corresponde a algema do escravo. E assim por deante. (MATTOSO, 2015) ${ }^{55}$

O trecho acima evidencia uma relação fecunda de princípio racional em confluência com sua condição enquanto sujeito cego. Isso nos leva à compreensão de que o escritor tem consciência de seu processo, o que the permite fazer escolhas sobre aquilo que vai ou não dizer literariamente; aquilo que servirá como "fértil palco para papéis típicos". A carnavalização mencionada como forma personificadora é um dado importante da criação enquanto possibilidade de se explorar questões fetichistas ou da própria condição, como no caso da cegueira e da podolatria. Dirá Bakhtin (2008) da força do processo da carnavalização como forma de deblaterar costumes, condutas, conceitos, valores e condições.

Por toda a obra do autor, nota-se, na linguagem explorada, uma angústia revestida de não aceitação dessa condição causada pelo glaucoma, pois traz em seu discurso a insatisfação e contrariedade àquilo que é irreversível.

Ao voltar nossos olhos para a angústia de Mattoso em relação à sua cegueira, presente em seus textos, e de como ela se tornou fator determinante para sua escrita literária, vem-nos um diálogo imediato com o conceito de finitude, que pode ser associado à morte, pois remete-se ao fim da forma. Nosso raciocínio compreende que a literatura de Mattoso, pela força que produz via discursos paradoxais, busca na linguagem uma maneira de resolver o conflito da finitude da visão (finitude esta podendo ser associada a uma ideia

\footnotetext{
${ }^{55}$ Disponível em:

http://www.blocosonline.com.br/literatura/prosa/colunistas/glauco/gm14emdiante/gmephem_ind ex.php
} 
de morte). Assim sendo, para que a "forma" não deixe de existir diante da perda de um sentido, ela é recondicionada ao processo de escrita, mantendose concreta diante desse momento vivido no espaço literário.

Enquanto finitude compreende o processo de encerramento, em que a duração como mediação entre princípio e fim - tão cara para a memória, dirá Bergson (1990) - permitirá a condução das coisas boas e ruins, existe, naturalmente, um limiar. Esse limiar pode ser compreendido, nas obras de Mattoso, como a transição da visão para a cegueira. Dessa feita, o espaço ocupado pela perda da visão, em Mattoso, é mais forte que qualquer outro elemento seu de criação. Entretanto, colocar a cegueira em primeiro plano não é uma ação particularmente deste trabalho, tendo em vista que o autor deixa entredizer em seu próprio nome e em toda a sua obra, que ele não é apenas um escritor cego, mas é um escritor porque é cego.

Dessa feita, Glauco Mattoso, ao se apropriar lilterariamente do nome da doença que o levou à cegueira, traz para perto de si, enquanto personagem, sua maior inimiga e tenta, a partir de uma autoironia e apropriação de textos, driblar a dor de uma condição de cego, aliando-se à mesma.

Para suportar o peso dessa transição visão/cegueira, a maneira encontrada pelo ortônimo Pedro José Ferreira da Silva foi a de dar ao glaucoma um espaço concreto em sua vida: o espaço de escritor. Isso nos dá condições de afirmar que o nome Glauco Mattoso não é apenas um pseudônimo, mas uma apropriação e personificação da doença, com intenção racional de torna-la íntima e aliada, como forma extensiva de si mesmo. Entretanto, nossa percepção não se vale das angústias íntimas de Pedro José, em suas maiores particularidades, mas daquilo que o próprio texto afirma, enquanto ficção: "já que a dor da cegueira é inexorável e indisfarçável" (MATTOSO, 2006, p. 246).

A estética glaucomattosiana ganha vida por meio de uma condição concretizada a partir do principal heterônimo criado por Pedro José: Glauco Mattoso. Isso torna a escrita do autor uma denunciadora da dor da iminência da cegueira, cujo glaucoma faz o papel de principal articulador identitário.

Eternizar na arte uma aparência é dar possibilidades para a permanência de uma realidade criada, permitindo a transição de uma condição indefinida para outra, agora definitiva. Glauco Mattoso sai do estar enxergando 
para o ficar cego: "Eu, Glauco, "fiquei" cego, não "sou” cego.'[...] (MATTOSO, 2011a, pág. 33).

Solha, na capa de Cautos Causos (2012) diz que Glauco Mattoso "lembra dois grandes artistas tragicos, para os quaes os dramas pessoaes foram a propria causa de sua agonia e de nosso extase: Van Gogh e Frida Kahlo." (SOLHA in MATTOSO, 2012)

Progressivamente, fui vendo a claridade esmaecer e as cores se reduzindo a nuances de cinza, até que o negror tomou conta de tudo, e me vi num pesadelo acordado, levitando sem apoio num espaço cósmico sem estrelas. (MATTOSO, 2006, p. 210)

Os fantasmas da memória literária de Glauco Mattoso estão presentes em seu universo noturno e sem estrelas. No Manual do podólatra amador, ele expõe essa solidão associada ao afastamento de "amigos" quando se tornou cego. $O$ isolamento, tal qual a solidão, são características que deduzem uma ideia de vazio. Uma inexistência causada pela dor da ausência do que se tinha.

\footnotetext{
Existe uma diferença entre morar só e viver só, mas depois de cego descobri a diferença entre viver só e só viver, isto é, pouco mais que vegetativamente, como em coma numa cama. Eu já morava só, e agora passaria a somar a escuridão ao silêncio.

Já aposentado por invalidez, me recolhi a uma espécie de prisão domiciliar perpétua, remoendo o ostracismo da vida literária... (MATTOSO, 2006, p. 210)
}

A finitude e dor da solidão, causadas pela cegueira e declaradas por Mattoso no Manual do podólatra amador, chegam ao fim por influência literária do grande poeta, o argentino Jorge Luís Borges, que, gradativamente, também ficou cego:

Assim escoaria o resto da década e do milênio, se um outro cego, talvez o mais célebre do século, não decidisse confabular lá do Além com Severino pra intervir no meu regime carcerário. Esse bruxo era Jorge Luis Borges. (MATTOSO, 2006, p.210)

A cegueira é uma possibilidade, uma voz reverberada pela consciência de GM, em que a tragédia da condição é reconstruída pelo estado épico do prazer pessoal: "Mattoso, que nasceu deficiente, ainda foi currado em plena 
infancia, [...] Merece o que o vaidoso não cobiça: um titulo que, alem de ser "poeta", será "da crueldade" por justiça." (MATTOSO, 2011a, pág. 5).

$\mathrm{Na}$ contrariedade ao poeta argentino, que tinha a cegueira como uma dádiva, pois a levou a uma outra visão de mundo, Glauco faz uma releitura do conto "O elogio da escuridão", de Borges:

Ser cego tem as suas vantagens. Pessoalmente, devo certas dádivas às sombras: o anglo-saxão e os rudimentos do islandês. Existe também a alegria de muitos poemas, além de ter escrito livros, inclusive um chamado, não sem alguma duplicidade, como se de um desafio se tratasse, O ELOGIO DA ESCURIDÃO. Os cegos também se sentem cercados de carinho. Todo mundo tem afeto pelos cegos. (BORGES, 200156)

**

Borges decidiu reinventar o futuro. Parecia ver o mundo com óculos cor-de-rosa. Tinha confiança nos médicos e tinha a confiança dos editores. Já era famoso quando cegou, e a cegueira só faria aumentar seu prestígio. Tinha motivos para não se lamentar. Comigo dava-se o inverso. Quanto mais cego, mais me apegava ao passado, às reminiscências da memória visual. Fiz dos traumas de infância (como os abusos sexuais de que fui vítima à mercê da molecada suburbana) a matéria-prima de minha poética sadomasoquista e escatológica. Desenganado pelos médicos, enganado pelos editores, perdi as esperanças de conviver pacificamente com a deficiência física e a indiferença alheia. Mas limitei-me a resumir no detalhe fetichista minhas divergências com Borges, que afinal apenas realçavam os denominadores comuns. (MATTOSO, 2001 ${ }^{57}$ )

Ao invés de ressaltar de maneira leve os pontos positivos da cegueira se existem -, assim como descreve Jorge Luís Borges, Glauco, em réplica no conto "A negação do negro", alude a cegueira como invasiva e irreversível, cruel, dramática e funesta.

Pensando na tragédia como uma ideia de conflito entre um personagem e uma força maior, no caso, Homem vs. condição humana, é possível associar o drama que Glauco Mattoso, em que vive, como personagem de si mesmo, dentro e fora do texto, a partir da iminência e, posteriormente, concretude da cegueira.

Soneto insone [234]

Ser cego é como estar numa prisão.

Ficar cego é pior, parece o susto

de quem foi livre e sofre o golpe injusto,

\footnotetext{
56 Idem.

57 Idem.
} 
levado para o hospício estando são.

O sonho é colorido, pois estão

bem vivas na memória, a muito custo, imagens dum recente e já vetusto

passado de prazer e perversão

Nenhum ouvido escuta meu apelo.

Acordo e lembro em pânico que o sonho

foi falso: a realidade é pesadelo.

Só volto a adormecer quando componho sonetos sobre o pé. Gozo ao lambê-lo, e agora o escuro não é tão medonho.

(MATTOSO, 1999a - sem indicativo de página)

Transformar uma dor em prazer, em desejo, permite a liberdade criativa. Convertida em literatura, a ação criativa de Glauco Mattoso parte do prazer que sente na dor da cegueira. E mais: a vontade do autor possibilita a (re)criação de si mesmo, pois se autorreconhece ao se assumir, poeticamente, numa uma existência às escuras, infinita, sempre marcada pela escolha do nome.

A autoconsciência é forma de liberdade e autonomia perante a ideia de criação. Em Mattoso, a ausência da visão gera esse "autoconhecimento, memória, ritual, insignificância do ser diante do universo e do tempo", pois "são algumas das inquietações suscitadas pela ausência" (RODRIGUES, 2008, p.123) - em Mattoso, a ausência da visão. Decerto, essas mesmas inquietações desestabilizam o processo da insignificância e incapacidade, reconstruindo o próprio estado de existência por meio de outro estado de condição.

O distanciamento como processo de autorreconhecimento, na obra glaucomattosiana, leva-nos a pensar no autor enquanto instância literária, em que Glauco Mattoso é resultado: extensão literária de Pedro José criada para lidar diretamente com a cegueira, pelo processo estético-literário de personificação. 
Pedro é Glauco?

Poeta que for cego, mudo ou mouco compensa a privação com a fuzarca: diverte-se sofrendo. É glauco. É louco.

Soneto Karmico - MATTOSO

De acordo com o professor e pesquisador Antonio Vicente Seraphim Pietroforte, no posfácio de Tripé do tripúdio (2011) de Glauco Mattoso, o escritor do JD explora a presença de "realidade" na ficção, induzindo o leitor a confundir seus textos com uma "vida real". Para o estudioso, isso é possível porque, ao aplicar funções de linguagem na construção de romances incluindo aqui a poesia - é possível compreender as relações entre ficção e realidade construídas por determinada tipologia textual, envolvidas por efeitos linguísticos ora denotativos, ora conotativos.

Quando o autor se torna personagem de si mesmo, fazendo com que haja interdiscursividade entre suas obras e os discursos a respeito de sua vida, criam-se efeitos de realidade em que tudo se passa como se a personagem e 0 autor fossem as mesmas pessoas. (PIETROFORTE in MATTOSO, 2011, pág. 176)

A figuração para a construção de si por meio da linguagem escrita gera efeitos semânticos que permitem, como em Glauco Mattoso, a personificação de um estado físico como representação de um outro estado, extensão de si. Pietroforte diz que

... a leitura atenta revela um autor que insiste, antes de tudo, em discursos substanciais. Todavia, na medida em que a função substancial nega a função mítica na linguagem, cabe indagar quais mitologias Glauco escolhe negar segundo a realidade que pretende construir em suas prosas e poesias, e com que valores ele faz essa negação. (PIETROFORTE in MATTOSO, 2011, pág. 178)

Como já trazido aqui, Glauco Mattoso, autor-narrador-personagem, constrói suas histórias e seus sonetos em cima de uma realidade manipulada a partir da autorreferência. Seu discurso está sustentado por elementos autobiográficos que reforçam a ideia de um escritor confessional, que se utiliza 
de um discurso para se expressar. Esse discurso autoficcional é fruto da condição do escritor e manipulado pela busca de uma identidade literária que consiga carregar a imagem metafórica por ele construída.

Ficar à margem me deu, ao mesmo tempo, consciência da incapacidade (que me sujeitava, inclusive, à humilhação) e da necessidade de adquirir algo que os outros não têm, para equilibrar um pouco a balança. A heteronímia está na raiz de tudo isso, o convívio com a realidade em dimensões antagônicas. (MATTOSO, sem indicativo de ano e página $)^{58}$

Nessa manipulação da realidade dentro da obra do escritor, que se permite confessional, está por trás o heterônimo, sustentado por uma estética. Para substancializar essa personificação em cima do discurso literário, o escritor se utiliza de articulações intertextuais e autotextuais, cuja intenção é a do convencimento da existência e predominância do escritor maldito, por meio da literatura.

A questão da heteronímia em Glauco Mattoso é muito mais explorada do que se imagina o leitor. Até início dos anos dois mil, Pedro Ulysses Campos foi tido como um dos críticos literários a estudar e comentar a obra de Mattoso, sendo referência em muitos trabalhos acadêmicos. Contudo, Campos é apenas um heterônimo criado por GM para falar de seu próprio trabalho, de forma crítica e sutilmente irônica, a legitimá-lo, revestido pela figura de um professor universitário. Susana Souto, em seu artigo Crítica Literária e heteronímia: Glauco Mattoso e Pedro Ulysses Campos ${ }^{59}$ (2010) explica:

A lúdica composição do nome, tipicamente glauquiana, aciona um
conjunto de referências intertextuais que enreda o leitor nas tramas
da sua biobibliografia. As iniciais brincam com a Pontifícia
Universidade Católica: PUC. Pedro é uma retomada irônica do nome
"verdadeiro" de Glauco Mattoso, Pedro José Ferreira da Silva. O
segundo, Ulysses, tem duplo desdobramento: tradicional, remetendo-
nos à épica grega; e moderna, levando-nos ao romance homônimo
de James Joyce. E, finalmente, Campos associa-se ao poeta Augusto
de Campos, um dos autores referenciais para Glauco. É ainda
atribuída uma profissão relacionada à leitura a Pedro Ulysses
Campos: ele é professor de literatura; outro dado biográfico: ele é
carioca. Serão analisados trabalhos assinados por Pedro Ulysses
Campos: o prefácio da antologia Poesia digesta: 1974-2004 (2004) e

58 Entrevista de Glauco Mattoso concedida ao Memorial (org./SP). Disponível em http://www.memorial.org.br/cbeal/poetas-na-bilbioteca/glauco-mattoso/entrevista-mattoso/ 59 Disponível em: < http://www.olhodagua.ibilce.unesp.br/index.php/Olhodagua/article/viewFile/50/61> 
textos publicados na página oficial do poeta na web, no quais podemos perceber os protocolos que orientam a leitura desse heterônimo e configuram sua noção de crítica literária, intimamente articulada à escrita híbrida glauquiana. (SOUTO, 2010, p. 117)

Além de Pedro Ulysses Campos, outros "Pedros" farão parte do arsenal heteronímico ${ }^{60}$ de Mattoso, configurando publicações no JD, na Revista Dedo Mingo e sendo citados em sua poesia. De todos, como dito na primeira parte deste trabalho, há de se destacar Pedro o Podre, devido à sua intensa colaboração com o DOBRABIL e maior proximidade com a figura transgressora de Glauco Mattoso.

A percepção de Glauco provém de um passado e estaciona-se no presente em que se encontra: o da cegueira total, irreversível, que agora faz parte dele. O heterônimo Glauco Mattoso já nasceu à espera da cegueira, pois nasceu quando Pedro José o escolheu e o apresentou, como poeta, ao mundo. E, claro, nenhum espaço é tão propício para se driblar os conflitos e dores da condição humana como o da arte.

Glauco se consagra ao abraçar sua criação estética, desconstruindo os infortúnios da própria condição e se assumindo como cego. Ele fixa sua essência na poesia, ironizando a dor do finamento da visão. O fim está na matéria, não na essência. Em Glauco, a essência é a palavra que se instaura na sua escrita ambígua, paradoxal, crua e, muitas vezes, funesta. Mas é seu autoescárnio o esplendor da sua estética.

Uma das condições para se identificar a construção heteronímica de um autor é pelo processo comparativo em que há publicações em nomes diferentes (ortônimo e heterônimo), cujas personalidades autorais desses nomes são facilmente diferenciadas. Embora saibamos que Glauco Mattoso publicou com o nome Glauco Mattoso todos os livros lançados por editoras, e não como Pedro José - exceto Línguas na Papa: Memórias de um pueteiro As melhores gozações de Glauco Mattoso (1982), em que nas referências consta o nome Pedro José Ferreira da Silva - sustentamos aqui que a heteronímia não é construída apenas pela contrariedade de duas

${ }^{60}$ Glauco Mattoso, atualmente, tem-me enviado, por e-mail, um grande arquivo de textos (principalmente sonetos) ainda não publicados, em que, boa parte de quem assina é composta por heterônimos por ele criados, cujos nomes sofrem inúmeros processos semânticos, como trocadilhos e anagramas. 
personalidades quando comparadas, mas, também, pela forma como essas identidades literárias foram criadas. No caso de Glauco Mattoso, o 'eu' por ele defendido numa escrita que se propõe confessional é fruto de uma construção estética a partir da personificação da doença.

Como personificar é um modo de dar vida a algo abstrato ou sem vida, compreendemos esse conceito como possibilidade única da ficção. De acordo com Moisés (2013), personificação é:

Figura retórica que consiste em atribuir vida, ou qualidades humanas, a seres inanimados, irracionais, ausentes, mortos ou abstratos. Espécie de humanização ou animismo, pode dar-se de vários modos, a saber: quando conferem qualificativos próprios do ser humano a objetos inanimados e a abstrações... (MOISÉS, 2013, p. 385).

Já Houaiss dirá:

Pessoa que encarna ou representa com perfeição uma ideia ou algo abstrato. Atribuição a seres inanimados, ou a algo abstrato, de ações, qualidades ou sentimentos próprios do homem; animismo, prosopopeia. Tendência psicológica que procura estabelecer analogia entre uma palavra abstrata e diversas imagens concretas. (HOUAISS, 1997, p.1246)

O sentido de personificação é claro quanto ao processo imaginativo da criação em torno de algo, cuja representação se dará em uma forma concreta e crível, a partir dos elementos criados para fins do processo de corporificação. A relação entre personificação e heteronímia é natural, pois ambas advém de um processo semântico da construção fictícia de um ser.

Não dá para falar de heteronímia sem mencionar o criador do neologismo, Fernando Pessoa. O poeta desenvolveu uma teoria sobre esse elemento de criação em que explica seu principal fundamento. Desde então o termo passou a ser utilizado e sempre referenciado ao poeta português. Para Pessoa, "Os heterônimos são qualquer coisa de estrutural na personalidade" (2012, pág. 12). A estrutura é composta de elementos que compõem a figura representada pela pessoa considerada, logo, construída esteticamente por um movimento semântico de exposição concreta. 
No livro Teoria da heteronímia (2011), uma reunião póstuma dos escritos de Pessoa sobre essa temática espalhada por sua obra, estão expostos como e por que o escritor criava novas personalidades, cujas linguagens se modificavam e novas "consciências", extrapoladas da criação, ganhavam espaço e reconhecimento.

Glauco Mattoso, além de metaforizar sua escrita pela figura fetichista do pé, explora a cegueira como objeto de humilhação e exclusão, utilizando-se de recursos estéticos da construção literária, em que a personificação da cegueira (em moldes do glaucoma) ganha forma e o representa, figurando-o como uma extensão de si mesmo.

Para ampliar-se em outros, Mattoso deixa-se dominar pela criação poética e joga com o leitor, que confunde ficção e realidade, poesia, memória e autobiografia. Escarnecendo, transita com liberdade pela ousadia do discurso confessional sexual e por reflexões da condição humana da forma mais irreverente e transgressora possível.

Mattoso tem em seu processo aquilo que Fernando Pessoa defende:

A obra [...] heterônima é do autor fora da sua pessoa, é de uma individualidade completa fabricada por ele, como o seriam os dizeres de qualquer personagem de qualquer drama. Assim sendo, conclui-se que o heterônimo é uma personagem de certo tipo: é o autor como personagem. (PESSOA, 2012, pág. 24 - grifo nosso)

E se é o autor como personagem, por que não o autor cuja personificação literária é a própria condição de cego?

Se sinto uma coisa, vagamente a sinto na pessoa visualizada de uma qualquer criatura que aparece em mim. Em resumo, o irresistível efeito-heterônimo, enquanto concretização em figura humana de toda a existência textual, é como que o efeito de uma visualização. (PESSOA, 2012, pág. 26-27)

Ainda em Teoria da heteronímia, foi possível compreender que essa questão não se limita somente à dramatização ficcional, mas está, também, ligada à complexidade do efeito de linguagem estabelecido pelo criador, que resume no processo do "enunciador específico estar indestrinçavelmente ligado a cada específico enunciado. $E$ tal heteronimização satura todos os campos da atividade literária possível." (PESSOA, 2012, pág. 27) 
O que significa heterônimo? Não é um nome falso por oposição a um nome verdadeiro (pseudônimo/autônimo). É antes o nome de um outro por oposição ao nome próprio (heterônimo/ortônimo). Assim passam o nome inventado e o nome verdadeiro a coexistir no plano complexo de uma realidade que os inclui a ambos, o inventado ganhando realidade, e o verdadeiro parecendo ficcionalizar-se. [...] Corresponde à ideia de transpersonalização, desdobramento ou outramento. (PESSOA, 2012, pág. 19)

As ideias de "nome verdadeiro" e "nome inventado", abordadas por Pessoa, estão como ocupantes de um mesmo espaço: o literário. Cientes do impasse já estabelecido aqui diante do ortônimo vs. heterônimo, qual o espaço que ambos ocupam literariamente, se as publicações são em nome de Glauco Mattoso? Desse modo, não contrapondo à visão pessoana de criação heteronímica, mas buscando a compreensão de 'outramento' em Mattoso, é possível chegar a esse 'outro', enquanto criação ficcional, logo, estética, pois um outro independente do espaço que coabita junto àquele que the atribuiu o nome. Ainda assim, Mattoso sustenta uma relação dicotômica entre heterônimo/ortônimo, Glauco e Pedro. Diz ele, um é dionisíaco enquanto o outro, apolíneo ${ }^{61}$. Essa oposição ao nome próprio é indagada por Glauco Mattoso no soneto $(\mathrm{XI})$ [3311], que é parte do conto "Rockabullying", publicado no livro Caustos Causos: "O Glauco era Pedrinho? E se recorda/ você dos nomes, quando cada aborda?" (MATTOSO, 2012, p. 142).

Nesse livro, cujos textos são contos "Iyricos" de Glauco Mattoso, o causo "Rockabullying" expõe depoimentos de fatos já narrados no Manual do podólatra amador. Nos sonetos, Mattoso cria vozes que dialogam entre si, como uma entrevista, em que uma indagação sobre a persona e o eu-lírico é feita sem uma resposta aparente no restante do conto, conduzindo-nos a pensar que o leitor é quem saberá identifica-los e diferenciá-los, Pedro de Glauco.

\author{
"Onde a dificuldade? É doloroso? \\ Ou falta só memoria ao 'eu' Mattoso?" \\ De facto, foi traumático, mas nada \\ me custa relembrar. O que complica
}

\footnotetext{
${ }^{61}$ Mattoso em entrevista: disponível em:

< http://www.revistas2.uepg.br/index.php/uniletras/article/viewFile/6733/4749>
} 
é a mente do poeta, hallucinada.

"Complica como?" Acabo misturando

veridico e fantástico: à punheta

da época se somma o que intrometa

a pena do escritor, e eu tudo expando.

Si eu desexaggerasse um pouco, em cada capitulo, o ocorrido, aquella rica

historia ficaria bem contada.

"Então vamos tentar! Serei curioso!"

Pois seja! E eu serei serio ate no gozo.

(MATTOSO, 2012, pág. 132 - grifo nosso)

Nota-se, no poema acima, a relação linguística explorada pelo escritor sobre a dicotomia verdade/ficção, cujas possibilidades se tornam infinitas na pena do escritor. Mattoso é agente manipulador da recepção do leitor por meio do que "confessa" em sua escrita.

Ademais, o que também colabora com a presença da heteronímia em GM são suas entrevistas. Em conversa com o escritor, perguntamos se Pedro José é Glauco Mattoso. Ele respondeu:

Eu diria que não. Eu diria que há uma dualidade, é um alter-ego, mas tem diferenças, sim. O Pedro verdadeiro, a personalidade do Pedro verdadeira eu acho que jamais será conhecida, porque tem alguns aspectos caretas, tem algumas coisas que não batem muito com a figura do autor maldito. O Pedro é mais careta, o Pedro é mais conservador, é mais rotineiro... (MATTOSO, 2012)

Para Pessoa, "A despersonalização é uma marca definidora das expressões plenamente realizadas de heteronímia" (2012, p.42). Glauco Mattoso despersonaliza a si mesmo, Pedro José (o que é tímido, conservador, cauteloso e, publicamente desconhecido, já que só se manifesta, fora da literatura, como Glauco Mattoso) e constrói o heterônimo, que é aquilo que comentamos como personificação de uma doença que pressiona, que avassala, cujas características próprias do sujeito cego se diferem de Pedro José, contradizendo-as. Portanto, a despersonalização pode ser uma negação de si em busca de uma parte que sofra menos: "O Pedro, mais filósofo, é de cal." (MATTOSO, 2000, pág. 103). 
Ás vezes o Pessoa era Caeiro
ou Álvaro de Campos, mais bem-vindo.
Poeta Lagartixa foi Laurindo.
Já Sócrates, Jobim, são Brasileiro.
Dom Pedro, antes de Quarto, foi Primeiro.
Renato ficou Bento, não tão lindo.
Por que será que o Sílvio vive rindo?
Porque trocou de nome e tem dinheiro.
Torelly foi Barão de Itararé.
Gonzaga foi Dirceu e Alceu, Tristão.
Julinho, senão Chico outro não é.
Qual é meu apelido de plantão?
Se for Glauco Mattoso, é o fã do pé,
ou não me chamo Pedro, o Podre, então.
Soneto onomástico [2.157] - Glauco Mattoso

Apesar do neologismo pessoano não dar conta da dimensão da criação heteronímica de Glauco Mattoso, nossa intenção não se compromete em reduzir um ao outro, mas em buscar modos mais cognoscíveis de se compreender a complexidade do nome 'Glauco Mattoso'. A justeza da análise alia-se aos depoimentos literários do autor quanto à apropriação do adjetivo transformado em nome próprio. Glaucomatoso é todo sujeito portador de glaucoma; Glauco Mattoso é 으 sujeito portador de glaucoma. Um ser particular, cuja identidade criada e moldada aos seus conformes, buscou na literatura o encaixe propício para a ficcionalização de si; seja pela associação a Gregório de Matos, seu grande influenciador na escrita fescenina; seja pela sua forte relação de criação heteronímica e mística presentes em Fernando Pessoa ${ }^{62}$.

Enquanto criação estética do Manual do podólatra amador, a escolha do nome é crucial para fundamentar a narrativa contada pelo falso didatismo de um manual fetichista. Por esta razão, para que se consolide a criação fictícia em diálogo tendencioso com uma realidade extraliterária, cabe ao nome sustentar essa figura concreta, articulada pela linguagem da criação.

\footnotetext{
62 Em entrevista a nós concedida, Mattoso fala de seu misticismo e das nuanças com a escrita heteronímica de Fernando Pessoa. Disponível em:

<http://www.revistas2.uepg.br/index.php/uniletras/article/viewFile/6733/4749>
} 


\title{
6.10 contexto da Ficção
}

\begin{abstract}
"Diariamente inúmeros absurdos são escritos sobre os personagens de ficção por aqueles que acreditam de mais e por aqueles que acreditam de menos no personagem. Os que acreditam de mais mantêm um férreo conjunto de ideias preconcebidas sobre eles: devem se fazer "conhecer", não devem ser "estereótipos", devem ter um "interior" e um exterior, profundidade e superfície, devem "crescer" e "se desenvolver" e devem ser pessoas de bem. Ou seja, deve ser muito parecidos com a gente."
\end{abstract}

(JAMES WOOD, 2012, p.91)

Há quem viva sem fiç̧ão? Incontestavelmente, a humanidade necessita, quer e concebe a ficção, seja no espaço da arte ou fora dele. Aristóteles (1999) já nos alertava sobre nossa natureza humana da imitação e do poder mimético que promove o ser, pois lhe atribui forças para se pensar a si mesmo, o outro e o mundo através da representação.

A ficção, enquanto conceito simples, ainda se concentra no processo de criação artística, em especial a literatura, conforme aponta Moisés:

FICĈÃO - Lat. Fictio, onis, de fingere, modelar, compor, imaginar, fingir. Sinônimo de imaginação ou invenção, encerra o próprio núcleo do conceito de Literatura: Literatura é a expressão dos conteúdos da imaginação, é ficção transmitida por meio da palavra escrita. (MOISÉS, 2013, p.191)

Embora seja na arte que ela melhor se realize, a criação/ficção, ultrapassando a antagônica ideia de "verdade", conduz as relações sociais, principalmente no espaço em que se permite a manipulação: o virtual. 
É cada vez mais notório o uso ficcional nos espaços sociais virtuais, em que o indivíduo consegue falsear um outro ser, parecido ou não consigo mesmo, conduzindo com distanciamento de autoria vs. criação seus elementos que credibilizam sua existência. Contudo, será realmente nas palavras que a fiç̧ão se traduzirá de modo mais eficaz, não só pela histórica compreensão da escrita poética enquanto mimese, mas, principalmente, pelo espaço fecundo de significação, ambivalência e pluralidades contidas em seus conceitos e significados.

Desse modo, convém retomar as discussões empreendidas no capítulo anterior, quando o ponto mais nevrálgico foi o de se pensar o espaço da ficção enquanto possibilidade de "outramento" daquele que escreve a história.

Glauco Mattoso mantém um terreno fértil de elementos memorialísticos reverberados em seu processo de criação, que sustenta sua percepção acerca de si mesmo, o escritor cego e podólotra e justificam de modo crível os fatos narrados ou rimados ao longo de seus escritos.

O que vai justificar a relação entre elementos que estão dentro e fora da literatura do autor é o narrador. Aquele que conta a história, que manipula o discurso, convence e pertence a um mundo real enquanto detentor do poder de contar a sua história, seja ela fictícia ou não.

Dessa feita, dirá Fernandes (1996), que o peso da escrita narrativa, embora ultrapasse o campo do romance e se articule com a escrita ensaística ou autobiográfica, por exemplo, implicam numa verdade interna incontestável, cuja construção mostra-se como um recurso importante para personificar, compor, apresentar e narrar. O gesto da narrativa ficcional desvela a história pela história. Seduz pela linguagem e afasta a necessidade de justificativa concreta e verídica para aquele texto narrado.

O narrador é então, naturalmente, um elemento da ficção, pois ele é instrumento e sua ferramenta de controle semântico é a linguagem (FERNANDES, 1996, p.87). Enquanto peça fundamental do processo de elaboração da ficção, o narrador equivalente ao autor e ao personagem que protagoniza a história, como é o caso de Glauco Mattoso, tem duplamente a força discursiva para conduzir sua história narrada, pois é o único a transitar livremente pelo espaço interno e externo do texto, articulando memórias, histórias e ficções. Nesse acesso livre, a criação glaucomattosiana joga com 
leitor questões que ultrapassam o texto literário, pois são críveis, incontestáveis diante de uma leitura primária, e verídicos enquanto discurso.

\subsection{Criação, verossimilhança e credibilidade em Glauco Mattoso}

"Se a verdade é destruição da ilusão de conhecer, se essa destruição se dá no sentido inverso do conhecimento e como destruição do próprio conhecimentos, então a verdade é mentira."

Michel Foucault Aulas sobre a vontade de saber

De todas as discussões aqui empreendidas, esta é, sem dúvidas, a mais delicada. Trazer à tona o conceito de credibilidade e verossimilhança na literatura é esbarrar em um terreno já sacralizado pelos estudos de teoria e crítica, em que as duas palavras, de alguma forma, caminham juntas - embora não há menção para o primeiro conceito, assumindo-o como um mero sinônimo do segundo. Seria possível separar essas duas palavras e suas dimensões literárias?

Parece ingênua e até desnecessária essa discussão, haja vista que, desde Platão e, principalmente, Aristóteles, a relação entre a criação e aspectos verossímeis já era discutida e compreendida como fator importante para a construção de elementos ficcionais, discorrida em Poética. Contudo, há algum tempo, as discussões empreendidas no grupo Epistemologia do Romance encontram diferenças nas duas significações, a partir da busca pelo conhecimento dentro do romance.

Antes de levarmos adiante nossas percepções acerca de divergências conceituais, traremos aqui o significado de cada uma das palavras, no dicionário comum (Bechara) e, posteriormente, o trazido por Moisés, acerca de verossimilhança:

Credibilidade sf: Condição do que ou de quem tem crédito (confiança). (BECHARA, 2011, p. 463) 
Verossimilhança sf: Qualidade do que é verossímil (aquilo que parece ou pode ser verdadeiro; plausível). Lit. Coerência da obra literária quanto aos fatos e personagens. (BECHARA, 2011, p. 1131)

Verossimilhança - Lat. Veri, verdade, similis, semelhante à. Verdade. (MOISÉS, 2013, p.476)

Os significados acima já antecipam um pouco do conflito por nós aqui promovido ao tratar, primeiro, da credibilidade como confiança; a verossimilhança, como coerência literária e, por fim, o mais curioso, é ter do dicionário de termos literários o conceito de verossimilhança como sinônimo de verdade. E o que seria essa verdade? Se é o verossímel a representação dela, o romance não é ficção?

Desde nossos primeiros esforços de análise da obra de Mattoso por meio da construção estética, valemo-nos daquilo que pautam nossa compreensão de criação de obra: elementos que se repetem, logo, tornam-se verdadeiros fora do espaço da ficção. Isso porque carregam consigo questões que são perceptíveis, cognoscíveis, que ultrapassam a significação da palavra e formulam uma história crível, para além do texto.

A análise do romance que busca por vestígios epistemológicos componentes de sua elaboração parte da observação feita a partir do processo crível criado entre leitor e obra. Wilton Barroso, ao analisar Madame Bovary, de Gustave Flaubert, defende a seguinte tese, como exemplo de conhecimento no romance ${ }^{63}$ : O escritor francês, antes de se debruçar pela escrita da "mulher infiel" Emma Bovary, para se valer da condição feminina no século XIX, explora arquivos jornalísticos, dados verídicos, depoimentos e observações longas do comportamento social. Dessa feita, Flaubert, pela busca de elementos de criação que são críveis, consegue, não só produzir um resultado verossímel, mas uma obra cuja credibilidade fora do texto foi tamanha, a ponto de contribuir para acusações contra o escritor. A única saída de Flaubert foi assumir-se como Emma: "Emma Bovary sou eu", dirá o escritor ${ }^{64}$.

\footnotetext{
${ }^{63}$ Disponível em: $<$ https://drive.google.com/file/d/OB3rYBdlpwpzbeC1CMWJXZ3dteW8/view?pref=2\&pli=1> ${ }_{64}$ Disponível em: < http://www.sul21.com.br/jornal/emma-bovary-sou-eu-madame-bovary-e-oprocesso-contra-flaubert/>
} 
Este exemplo de como o autor criou sua narrativa é só uma das possibilidades de se conhecer o processo criativo de Flaubert. Evidentemente que, no caso do escritor francês, que, postumamente, possui um generoso arquivo que salta aos olhos do crítico geneticista, é um presente para aqueles que se propõem analíticos epistemologicamente. Nem todos os autores deixam esses vestígios. Portanto, buscar por elementos críveis no processo de criação vai além da leitura analítica do texto pelo texto. Essa ação exige uma investigação de obra (como o conjunto de publicações do autor), de modo a recolher vestígios e compreender como se repetem fora da história do texto.

A recepção do livro, na época, foi crucial para que, hoje, Barroso se debruçasse na pesquisa do romance a partir desses indícios deixados pelo escritor em busca de fomentar seu processo crível, ultrapassando a ideia de verossimilhança.

Em Poética, Aristóteles defende o conceito como algo próximo à aparência de verdadeiro ou da "verdade", não sendo, por contradição, completamente oposta à possível realidade, nem uma verdade decretada - um meio-termo. Ele expunha que o ofício da poesia acontecia pelo processo de necessidade e representação de uma realidade, sendo fundamental para a criação artística.

O historiador e o poeta não se distinguem por escrever em verso ou prosa; (...) a diferença é que um relata os acontecimentos que de fato sucederam, enquanto o outro fala das coisas que poderiam suceder. E é por esse motivo que a poesia contém mais filosofia e circunspecção do que a história; a primeira trata das coisas universais, enquanto a segunda cuida do particular. Entendo que tratar de coisas universais significa atribuir a alguém ideias e atos que, por necessidade ou verossimilhança, a natureza desse alguém exige; a poesia, desse modo, visa ao universal, mesmo quando dá nomes a suas personagens. (ARISTÓTELES, 1999, p. 47)

De fato, a criação da obra literária parte do processo de cópia da realidade, definidos pelo conceito de mimesis, contido nas obras de Platão e Aristóteles. A palavra, original do grego, significa "Gr. mímesis; lat. Imitativo, onis, imitação" (MOISÉS, 2013, p. 301). Na descrição conceitual de Moisés, a palavra mimese passa por várias interpretações ao longo dos estudos da criação e poesia. O vocabulário foi inicialmente empregado como imitação, representação, indicação, etc. Mas será com Platão e Aristóteles que o 
conceito ganhará maiores aprofundamentos, desdobrando-se no que se compreende hoje como elemento da criação estética como representação da realidade.

Como seres dotados de linguagem, a mimesis é natural e parte do nosso processo social e evolutivo, pois permite novas representações a partir daquilo que se observa e/ou vivencia. Enquanto processo de criação, caminha pelo terreno da ficção, possibilitando novas representações de uma "realidade copiada", multiplicando seu significado e conduzindo-a a outros planos linguísticos.

A cópia da realidade em busca da representação verossímil também parte da necessidade de construir um vínculo de credibilidade entre expectador e obra. Mas será mesmo que esse vínculo é sempre construído ou é possível perceber que a busca pela credibilidade tem um empenho muito maior na sua elaboração do que aspectos da verossimilhança?

Uma das maneiras mais simples de se compreender o processo verossímil é a partir da observação das imagens representadas nas telas do cinema. Um filme de ficção científica ou fantasia, por exemplo, buscam elementos verossímeis variados, de maneira a tornar a obra mais próxima de uma possível realidade para aquele que a assiste. Mas é nitidamente uma realidade inventada, existente apenas dentro daquele espaço. Entretanto, ao experienciar um filme dessas condições, o expectador não passará a crer naqueles elementos ali construídos, mas terá uma percepção de crença na forma como aquilo foi feito e é reproduzido. Ou seja, é verossímil, do ponto de vista de que a realidade é única e interna à obra, independente de seu processo de elaboração; enquanto a credibilidade existirá se houver um contrato de confiança existente entre o que foi criado, sua interpretação e identificação fora do espaço da obra de arte.

Voltando ao texto de Glauco Mattoso, o Manual do podólatra amador, bem como as referências de boa parte de sua obra, tem-se um processo um pouco mais delicado de construção verossímil, a ponto de extrapolar o espaço entre ficção e realidade e conduzir o leitor a transitar por esses dois núcleos sem uma consideração bem definida acerca de arte e realidade.

Em nenhum momento queremos desconsiderar a verdade interna à obra e trazer para o primeiro plano, aspectos externos que sobreponham o texto 
literário e a criação na arte. Acontece que, na busca por elementos de construção autoficcional e heteronímica, elaborados pelo escritor Glauco, percebemos que a relação tênue entre os espaços da ficção e da "realidade" são mais pretensiosos do que se propõe qualquer análise do Manual, e, consequentemente, indissociáveis das discussões aqui empreendidas.

No "Soneto versossímel". Mattoso declara:

\begin{abstract}
Verdade dói, é dura, impiedosa.
Mentira piedosa é traição.

As tais meias-verdades nada são

além de deslavada e mole prosa

Se toda reticência é duvidosa, se a peta pede só condenação, qual deve ser, então a solução que desmascare a farsa cor-de-rosa?

Falar abertamente não compensa. a sério e sem rebuços, o feitiço reverte ao feiticeiro a desavença.

Dois meios só, pra dar um jeito nisso tirando a falsidade e o tom de ofensa: brincar e poetar, sem compromisso...
\end{abstract}

(MATTOSO, 1999b, sem indicativo de página)

O descompromisso com a verdade, defendido por Mattoso no soneto acima, dialoga com a construção do texto em prosa, o Manual, destituindo o escritor de qualquer culpa da interpretação e confiança criada pela relação do leitor com o texto - embora já no seu introito, Mattoso traga definições dicionarizadas, críveis, e elementos de característica autobiográfica, buscando construir aquele pacto anteriormente discutido. Mesmo que o autor se proponha livre de culpa, sua escrita articulada por elementos próprios da relação ficção vs. realidade são propositalmente construídos para romper com qualquer sedimentação de conceitos ou representações dentro da esfera da criação literária. Mattoso, ao passo que não cria vínculos com a realidade, convida seu leitor a criar esses vínculos por conta própria, a partir da sua intepretação da obra.

Em Mimesis (2011), Erich Auerbach, ao discorrer sobre textos antigos a modernos acerca de seus processos de construção mimética, aponta a 
necessidade e interesse desses autores em compor a partir de características de verossimilhança, delimitadas ou não, pelo processo inventivo do escritor. Para ele, há uma necessidade latente em se construir textos "autênticos", principalmente quando se pretende, por meio da criação literária, a preservação de uma história e da cultura de uma civilização.

De forma plausível, compreende-se que o papel do escritor vai além das propriedades da arte desvinculada de qualquer intencionalidade, haja vista a obra de Mattoso, que, pela construção metalinguística, compõe uma série de elementos críveis extratextuais, que se propõem mantenedores de uma história da literatura, articulados pelo intertexto poético de obras consagradas. Fomentado por esses intertextos, a escrita confessional chega ao processo autoficcional, por estar intrinsecamente ligada à linguagem literária e confessional, desconstruindo a rigidez de uma verdade na interpretação desses depoimentos e permitindo realidades plurais.

Hans Vaihinger, em A filosofia do como se (2009), discute a ficção a partir do termo composto pela partícula "se", cuja definição compreende, tanto o processo de comparação como o de possibilidade da realidade. Para 0 filósofo, a ficção é uma criação consciente e tem, em sua gênese, a ideia de finalidade.

Ao explicar o termo "como se" (p. 671-710), Vaihinger descreve o caminho percorrido a partir dos estudos e aprofundamento nas obras de muitos filósofos, enfatizando sua afinidade com a filosofia de Kant, Schoppenhauer e Nietzsche, principalmente quanto ao conceito de vontade. Para o filósofo, a vontade promove a finalidade, ou seja, é pela finalidade que a vontade se realiza, sendo, portanto, fundamental para a construção de uma realidade. (2009, p. 681)

A relação entre Schopenhauer e Kant se dava principalmente pela harmonia de suas ideias quanto ao primado do prático em diálogo com a vontade do ser.

A vontade é proveniente de estímulos que, "Devem resultar em sensações elementares que então provocam movimentos correspondentes, os quais representam o começo mais elementar das ações da vontade." (VAIHINGER, 2009, p. 683) 
Chamei a esta obra de $A$ filosofia do como se, título que me parecia expressar com mais clareza aquilo que eu queria dizer: o como se, a aparência (Schein), o conscientemente-falso (Bewusst-Falsche) desempenham papel enorme na ciência, na concepção de mundo e na vida. Eu queria arrolar todos os métodos em que operamos intencionalmente com representações ou juízos conscientementefalsos... (VAIHINGER, 2009, p. 697-698)

Para Vaihinger, a ficção nasce de toda e qualquer ideia proveniente da necessidade, tanto intelectual quanto ética, do processo racional do homem em relação com sua sensibilidade e experiência do 'estar no mundo'. Dessa forma, é impossível instituir uma visão objetiva das coisas, pois, se há espaço para o racional é porque o irracional também existe - este, incomensurável pela lógica. Em $A$ filosofia do como se não há a defesa de polos contrários entre razão e ficção, pois esta é dotada de finalidade, fruto da vontade de saber, ser e reconhecer.

Como possibilidade de compreensão da obra de Glauco Mattoso, Vaihinger permite pensar os espaços ocupados pelo processo de criação do autor, em que a dicotomia entre a razão e a ficção é condicionada à vontade do poeta. Do ponto de vista kantiano, pensando na vontade como necessidade harmônica do ser em relação ao seu 'estar no mundo', condiciona-se a escrita glaucomattosiana a um processo cuja finalidade parte senão da sua condição humana, representada por uma visão subjetiva da cegueira. A ficção nasce, portanto, do ponto de vista real do autor, condicionado pelo conflito da sua existência.

A ficção possuindo interpretações variáveis de acordo com pontos de vista destitui a ideia de verdade absoluta, ocupando o espaço das possibilidades de verdades na linguagem, na criação, na ciência, na filosofia.

Para Slavoj Žižek, em A visão em paralaxe (2008), um mesmo ponto pode ter ideias divergentes, completamente opostas, em que a paralaxe media o terreno da linguagem, alterando o ponto de vista e a interpretação. Dessa forma, a realidade é construída entre as multiplicidades de pontos de vista e suas possibilidades (2008, p.19). Žižek permite pensar as diferenças entre questões do âmbito privado e do caráter universal e a forma como são jogadas no campo do absolutismo e da validade geral. 
As ações subjetivas por trás da construção ficcional compõem o espaço ocupado pela palavra na literatura, em que o autor se propõe distante de seu objeto, mas é indissociável dele enquanto sujeito que cria e é dotado de vontade, logo, produtor por finalidade. Dessa forma, ele elabora poeticamente um objeto que incomoda, cujo gesto é do de perturbar o funcionamento interpretativo do sujeito que experiencia o objeto. Segundo Žižek,

... o objeto é aquilo que objeta, aquilo que perturba o funcionamento tranquilo das coisas. Assim, o paradoxo é que os papéis são invertidos (em termos da noção padrão de sujeito ativo que age sobre o objeto passivo): o sujeito é definido pela passividade fundamental e é do objeto que vem o movimento - é ele que incomoda. Mas, novamente, que objeto é esse? A resposta é: o objeto paraláctico. (ŽIŽEK: 2008, p. 31)

Partindo da ideia de diferença, proposta por Žižek, a mediação entre sujeito e objeto, construída pelo viés interpretativo daquele que reflete sobre seu processo de conceitualização e interpretação do real, de acordo com sua compreensão dos espaços simbólicos, parte, senão, da diferença do objeto em si mesmo.

Em Glauco Mattoso, as diferenças criadas no espaço hermenêutico da gênesis do texto, bem como sua definição de gênero enquanto objeto literário, - Manual se permanece no entre-espaço da ficção/realidade, em que, por meio desse conflito de significações gerado, cria-se o ponto de interpretação do leitor que se propõe pesquisador, cujo olhar buscará compreensão, tanto da diferença, quanto do paradoxo.

A realidade que se defende fora da literatura não traz a mesma ideia de realidade na construção da autoficção e da heteronímia, pois estas estão no campo da criação estética e independem dos pontos de vista construídos pelo processo de recepção da obra. São articuladas enquanto objeto proveniente da relação sujeito (criador) vs. objeto (obra literária), em que a mediação pode, também, ser feita pelo leitor, que se propõe livre de conceitos, enquanto fruidor, mas historiador, enquanto analítico. 

Terceira parte
O ANTIESTÉTICO

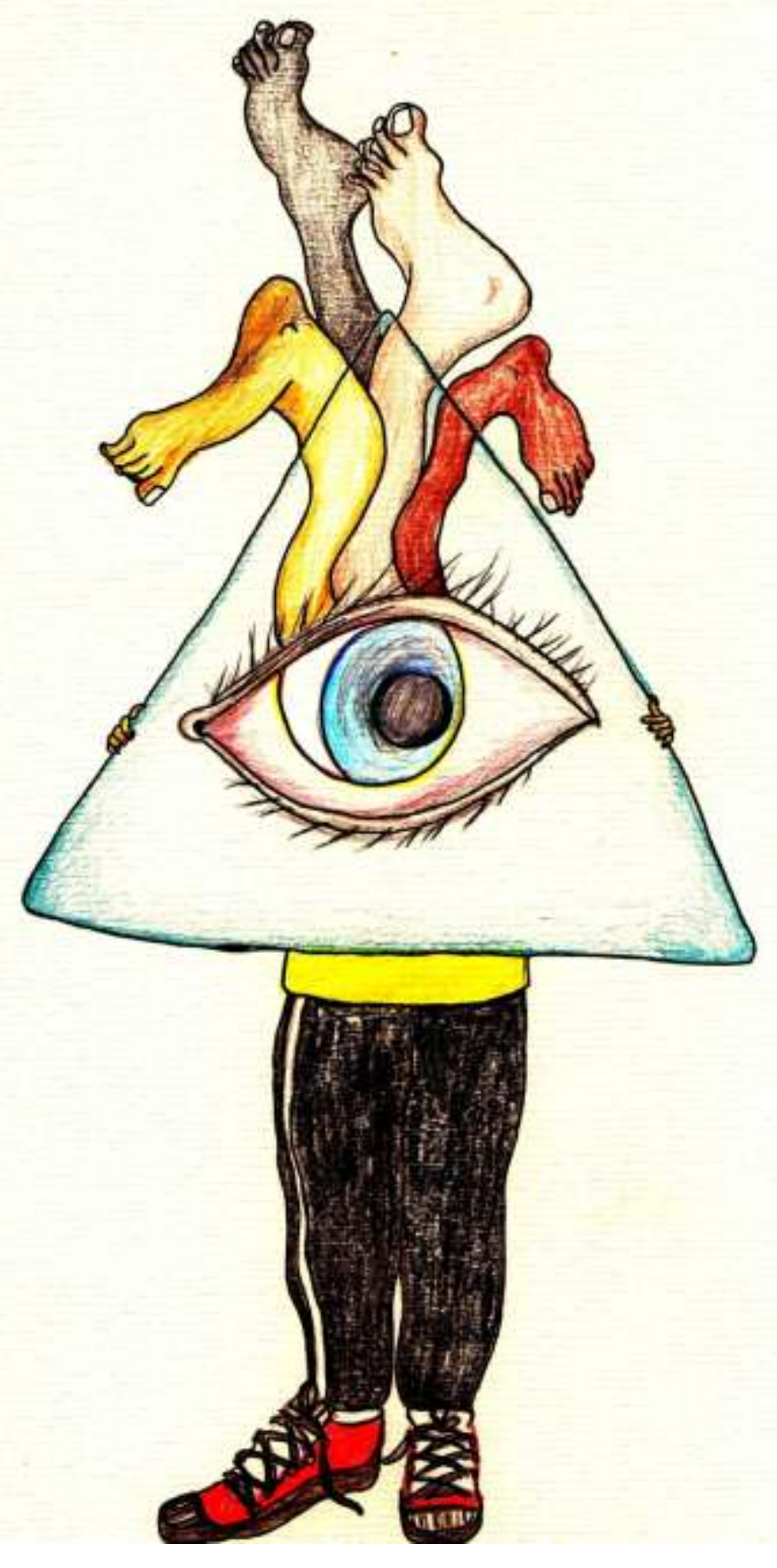

O olho saturado. Ana Paula Caixeta, 2016. 


\subsection{Entre a poética e a estética}

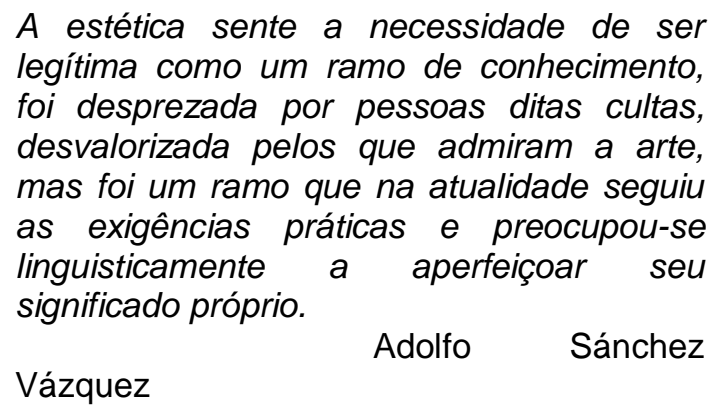

A criação, como falamos em outros momentos, é uma propriedade humana. A criação artística, enquanto possibilidade de manifestação concreta de questões que são sensíveis, é uma necessidade humana. Necessidade que só se realiza por meio da estética. Sendo assim, embora pareçamos exaustivos pela insistência do nosso olhar de investigação, justificar a estética como princípio da razão na arte é, principalmente, valorizar a criação artística em um momentos de banalização.

Lipovetsky e Serroy, em $A$ estetização do mundo (2015), falarão de como a estética se tornou uma ferramenta extremamente eficaz, quando explorada no contexto artístico mercadológico. Pela estética, se controla, seduz, faz divertir, consumir. Ignorá-la na atualidade é negar ao sujeito contemporâneo a possibilidade de compreensão, escolha e opinião.

Imannuel Kant, ao propor o estudo da razão, embasou-se em três princípios: a ética, a estética e a lógica. Ele pretendeu buscar o entendimento do pensamento humano a partir dos caminhos trilhados, principalmente pela ética, cuja influência ia ao encontro do gosto e da lógica, e, por sua vez, do juízo de entendimento das coisas em sua relação de efeito.

Kant defendia a faculdade do juízo como uma faculdade de pensar o particular como contido no universal. Este universal, por conseguinte, 
subsume o particular, é determinante (o mesmo acontece se ela, enquanto faculdade de juízo transcendental, indica a priori as condições de acordo com as quais apenas naquele universal é possível subsumir). Porém, se só o particular for dado, para o qual ela deve encontrar o universal, então a faculdade do juízo é simplesmente reflexiva. (KANT, 2010, p. 23)

O entendimento das coisas universais a partir da faculdade de julgar é composto por leis e dados cujo princípio é transcendental, representado pela condição do universal e reduzindo a condição das coisas a um julgamento a priori.

Retomando a ideia de transcendência em Kant,

também caracterizada como filosofia transcendental, trata-se do ponto de vista que considera as condições de possibilidade de todo conhecimento. Nesse sentido, não deve ser confundido com o termo "transcendente". "Chamo transcendental todo conhecimento que, em geral, se ocupa menos dos objetos do que de nossos conceitos a priori dos objetos. Um sistema de conceitos desse tipo seria denominado filosofia transcendental... Não devemos denominar transcendental todo conhecimento a priori, mas apenas aquele pelo qual sabemos que e como certas representações (intuições e conceitos) são aplicadas ou possíveis simplesmente a priori ("transcendental" quer dizer possibilidade ou uso a priori do conhecimento)" (Kant, Crítica da razão pura). (KANT in JAPIASSÚ e MARCONDES, 1996, p.263)

O conhecimento a priori trazido para o diálogo entre sujeito e objeto é proposto a partir da anulação de qualquer conceito a posteriori ligado ao objeto, cujo conhecimento se dá somente do ponto de vista daquele que contempla, sem uma relação dialógica com os elementos que formam e completam o objeto da relação. No caso desta pesquisa, no texto literário em consonância com o leitor.

A faculdade de juízo reflexiva, por sua vez, tem como princípio e fundamento o entendimento natural e particular, possível a partir do processo empírico fruto da relação entre sujeito e objeto, respeitando, por sua vez seus fins e sua natureza em si.

Ao falar de conceito e arte partindo de princípios kantianos gera, naturalmente, alguns conflitos. De fato, Kant propõe a relação entre sujeito e objeto, pelo ajuizamento de gosto, uma relação de experiência livre de 
conceitos, logo, livre de história. Entretanto, sua crítica ao gosto parte de um ponto elementar para se pensar a contemplação da arte, que é a experiência.

É nisso que iremos pautar nossas discussões, pensando a partir de uma das perguntas kantianas, contidas na Crítica da Razão Pura: $\underline{\mathrm{O} \text { que eu posso }}$ saber do objeto? (2015, p. 584). Nossa ousadia se encontra em unir uma questão kantiana, dotada de conhecimento e razão, ao espaço da fruição e do gosto, em que se pretende livre de conceitos e fruto apenas do efeito, julgado a priori. Nosso objeto nos dá respostas que vão além da fruição, pois também parte de conflitos da condição humana.

A experiência sensível na arte, para nós, não está somente no efeito estético entre sujeito e objeto, mas no efeito e conflitos gerados na feitura desse objeto, que requer, em sua composição, explorações que vão ao encontro da história e agregações semânticas para compreensão de si em consonância com o mundo.

Kant defenderá a estética como algo próprio e inerente ao sujeito, que é dotado de capacidade de fruição, como qualquer outra cognição humana, independentemente do conhecimento, já que a percepção do sujeito em relação ao objeto partirá da plenitude desse contato e não de aspectos e características indissociáveis do objeto. Ao permitir ao sujeito que contempla a força primária para a experiência com a arte, o objeto deixa de carregar as variâncias da crítica, tornando o sujeito ativo no processo de efeito. Em Mattoso, o objeto sofre variâncias, não do ponto de vista do sujeito que observa, mas do próprio objeto, cuja história e ressignificação, como no caso do Manual do pedólatra amador, são condicionadas à estética criada pelo autor. Que condicionantes são esses? Os temas, que dialogam com a história social do autor; os discursos e recursos linguísticos, datados de uma época; as escolhas transgressoras, que dessacraliza a "literatura maior"; a ficcionalização de si, forte instrumento para falar o que quer sem se comprometer.

Ao se pensar em estrutura literária no contexto contemporâneo, da qual se originará desdobramentos da linguagem, o pensamento kantiano resolve bem diversas problemáticas (mas nem todas), principalmente no que concerne ao âmbito da experiência sensível. Isso acontece porque, por um ponto de vista kantiano, o texto é analisado e interpretado por aquilo que ele, o texto, oferece, no instante da experiência estética. Entretanto, quando se pensa 
epistemologicamente o objeto de análise literária, já se pressupõe conceitos externos à obra e percebidos a posteriori para possibilidades do processo hermenêutico do texto.

Dessa feita, F. Hegel, discordará de Kant ao trazer para o cerne da contemplação os conceitos agregados ao objeto, bem como àquele sujeito que contempla, em um mesmo grau de importância. Segundo Hegel, o ponto de partida para a estética nasce na filosofia do Belo como ciência, cujo objeto é de ordem espiritual:

Qualquer que seja o objeto de uma ciência e qualquer que seja a própria ciência, em dois pontos se deve demorar a nossa atenção: um, o de que tal objeto existe, outro, o de saber aquilo que ele é. (HEGEL, 2009, P.5).

Saber sobre o objeto é compreender seu processo estético de formação, cuja origem está na relação dialética da criação artística.

Em se tratando de história e processo dialético, bem como da arte como ciência, Hegel contemplará de maneira mais aprofundada os estudos do Belo. Dialogando com nossa análise, cuja esfera engloba o limiar entre verdade e fiç̧ão, apontadas na parte anterior, o pensamento hegeliano, em acordo com a teoria kantiana de efeito, permite pensar dialeticamente o conflito gerado na complexidade da criação literária de Mattoso, bem como os conflitos da leitura enquanto pesquisa.

Hegel propõe três ideias relativas ao empirismo na obra de arte:

\footnotetext{
1 - As obras de arte não são produtos naturais, mas produtos humanos.

$2^{\circ}$ - As obras de arte são criadas para o homem e, embora ocorram ao mundo sensível, dirigem-se à sensibilidade do homem; de um modo próprio, a arte confina o mundo sensível, mas é difícil traçar o limite entre ambos.

$3^{\circ}$ - A obra de arte tem um fim particular que lhe é iminente.

(HEGEL, 2009, p.45)
}

A partir desses três pressupostos, compreendemos que a criação do objeto artístico, independentemente de sua linguagem (visual, verbal, poética...), parte da relação e experiência sensível entre sujeito que cria e 
criação, bem como gera um efeito sensível entre aquele que observa e/ou analisa o objeto em questão.

Em busca de conhecimento dentro do objeto de arte, assumimos o papel daquele que busca compreensão na relação sensível da criação artística como um movimento, também, composto de razão, colocado no âmbito da ciência, conforme propõe Diderot e d'Alambert (in BARROSO, 2003).

Se intencionamos pensar o objeto a partir de elementos de conhecimento que o compõem, também estamos ampliando o horizonte de expectativa de um leitor-pesquisador, em que o texto, por si só, não permite uma completude maior de interpretação senão pela exploração dos elementos que estão externos ao texto e ligados ao autor. Isso já defende nossa escolha pelos estudos estéticos acerca da construção contextual, autoficcional, heteronímica e antikitsch, por exemplo.

Estética e poética, como forma de compreensão do texto, são consumidas, muitas vezes, por um discurso do senso comum, conforme aponta Antoine Compagnon em O demônio da teoria (2010), complementadas por diversos olhares, cuja universalidade do cânone, o valor literário e a hierarquia formam um conjunto de sistemas analíticos que caminham paralelamente.

Nossa análise da obra Mattoso, ainda pensando nos aspectos abordados por Compangon, parte segundo uma visão além da função e forma literárias, além da emoção e ajuizamento, em que o olhar e a demora sobre as questões trazidas por Mattoso em seus textos promovem uma aprendizagem e sensibilidade que diz respeito, sobretudo, à literatura como espaço de transformação sensível. Seja pelo intertexto, seja pelo retorno histórico-literário, Mattoso promove discussão e (des)acomoda o leitor em seu espaço.

Tzvetan Todorov, em Estruturalismo e Poética (1976), define a compreensão de poética por um viés estrutural, em que se vê no objeto de conhecimento elementos suficientes para sua compreensão, desconsiderando os espaços extraliterários. Posteriormente, tem-se nos estudos pósestruturalistas, um rompimento com a rigidez proposta por parte dos estruturalistas, destacando outras áreas do saber como possibilidade de compreensão do texto literário, tal qual os aspectos que circundam o fazer artístico no espaço da Literatura. 
Diante de questões pós-estruturalistas, buscamos pontos de convergências, em que, pela análise epistemológica, assume-se, diante do objeto, conhecimento agregado dentro da obra de arte. Conhecimento este, que se repete, compõe e define elementos-chave no processo criativo do autor, bem como a composição do objeto por ele criado sensivelmente: a literatura, gosto por pés, a tortura, a dor, o prazer...

Ao pensar em estética, não só do ponto de vista da fruição, mas da relação sensível entre sujeito criador vs. criação, tem-se como possibilidades a compreensão da escolha estética do autor para compor sua obra. Uma escolha que ultrapassa a ideia da poética como ação mimética da criação ficcional. A poética (ARISTÓTELES, 1999), compreendemos aqui, seria, então, derivação de um processo estético primeiro, oriundo da relação sensível que promove a dialética da criação pela representação e materialização da Ideia (pensando no termo hegeliano). Mas a escolha de Mattoso é estética pela amplitude do olhar da obra: relação com a cegueira com a palavra e com o espaço que ela ocupa; necessidade de reforço identitário; transgressão. Nesse processo, o autor cria sua verdade individual e se refaz, conscientemente, no particular da criação literária, que é estética. 


\subsection{A conversão da dor em gozo}

"Se há uma coisa que excita mais os animais que o prazer é a dor".

Umberto Eco - O nome da rosa

O prazer pela dor, principalmente pela dor do outro é algo politicamente incorreto. Foucault, em Microfísica do poder (2015), vai falar do poder e dos mecanismos existentes para seu controle: o direito e a verdade. Por sermos obrigados a reproduzir e vivenciar verdade, dirá o filósofo, somos, ao mesmo tempo, submetidos à verdade imposta, construída pelos discursos maiores, que vão ditando aquilo que deve ou não ser classificado como verdadeiro.

A ideia de politicamente correto, na linguagem, refere-se a aspectos éticos e morais definidos por discursos políticos maiores, cuja intenção é neutralizar termos que se propõem discriminatórios e podem ser ofensivos ao indivíduo ou grupo social do qual ele faz parte. Em geral, a transgressão do politicamente correto acontece dentro de espaços diversos, principalmente o do humor, em que a ideia de liberdade pode, de alguma forma, sobrepor-se aos princípios do outro, bem como de sua condição, escolha, cultura e comportamento.

A escrita glaucomattosiana é deliberadamente assumida pelo autor como uma escrita transgressora, em que a ideia de politicamente correto é abolida pela linguagem sexual explorada em seu significado mais burlesco possível, cuja intenção é fomentar uma estética opositora ao socialmente imposto e aceito pela maioria.

No Manual do podólatra amador, bem como toda a obra de Glauco Mattoso, uma postura politicamente incorreta é assumida por meio de linguagem que, pelas temáticas incômodas, transgride e fere espaços, 
contrapondo-se aos valores éticos, que são convertidos em estéticos pela literatura.

Como já trazido aqui, a tortura, o bullying, a humilhação sofrida por um portador de deficiência visual, a exclusão e a exposição fetichista deliberada são temáticas que rompem com paradigmas e princípios dentro de esferas legitimadas de discursos e pontos de vistas, indestrinçavelmente rígidos e pouco dialógicos. Em Mattoso, essas temáticas são representadas por elementos abjetos, desconstruindo todo e qualquer invólucro criado em torno de questões pouco comentadas fora do espaço da arte.

As transgressões construídas pelo autor são fomentadas por um assunto-chave, cujo princípio e finalidade é o gozo daquele que se propõe escritor maldito. Nessa perspectiva, a sexualidade e o sexo dão forma à linguagem depoente de sua escrita confessional, em que a exploração é destituída do privado e colocada abertamente no objeto de criação literária.

Em Glauco Mattoso, há uma diferença nítida entre as discussões do pornográfico e do erótico como articuladores do discurso sexual por ele adotado. O autor defende uma escrita sadomasoquista, convertendo em prazer a angústia e dor por ele vivida em decorrência de sua condição de cego. Especificamente, o autor conceitua a pornografia no âmbito da criação, como uma possibilidade de arte, a partir do movimento e explorações de linguagens conduzidas por aquele que cria.

Pornografia. Discute-se muito se a palavra se aplica também às manifestações artísticas ou se está restrita ao material meramente obsceno, de interesse comercial. Discute-se ainda se implica numa função moralista, reforçando o lado proibido \& reprimido do sexo, ao invés de liberá-lo. (...) Se o tema sexo é explícito, a obra será automaticamente pornográfica. Acontece que existe a boa e má pornografia, assim como qualquer outro tema pode ser motivo duma verdadeira obra de arte ou duma fajutice. Tudo só depende da habilidade \& do talento criativo do autor, além do que, como dizia Wilde, "um livro não é, de modo algum, moral ou imoral; os livros são bem ou mal escritos, eis tudo". (MATTOSO, 2006, p.137)

Segundo Raimundo Martins,

O corpo é fonte e foco de inquietações, necessidades e desejos que transforam em práticas e hábitos ao mesmo tempo em que saciam noções de existência e alteridade em relação com indivíduos e coletividades tão diversos e complexos quanto o mundo que os constituiu e os cerca. (MARTINS, 2008, p. 9). 
Dessa forma, as questões ligadas ao corpo são parte de um espaço por ele ocupado em que a contradição de significados e experimentações configuram valores simbólicos, que formam manifestações por linguagens diversas, a fim de explorar, cada vez mais, esses espaços de relação.

Aqui não está em questão o corpo e suas configurações enquanto algo ocupante de espaço no mundo e passível de linguagem e transição, mas, especificamente, da linguagem por ele esteticamente representada a partir desse espaço ocupado por questões ligadas à sexualidade, logo, representativas do corpo.

A sexualidade, segundo Michel Foucault, sempre foi determinada por dispositivos de poder, em que o sujeito é dominado por um sistema que sustenta um discurso maior sobre o espaço que o sexo deve ocupar (FOUCAULT, 2011).

Nessa perspectiva, dominar o discurso sexual é também uma maneira de dominar sua própria sexualidade, pois a palavra se altera e se modifica para que se enquadre ao moralmente aceitável e útil (FOUCAULT, 2011, p. 27).

Glauco Mattoso se utiliza da linguagem literária em narrativas cujas características rompem com circunstâncias tradicionais e legitimadas, interdizendo seu desejo por um discurso destituído de poder, enquanto individual, mas legitimado, ao passo que é universalizado (e legitimado) pela arte.

"A transgressão organizada forma com o interdito um conjunto que define a vida social (...)" (BATAILLE, 2003, p. 89). Defendido por Mattoso, seu conjunto enquanto obra está nos limites da criação literária, da sexualidade e do politicamente correto, haja vista que é formado, não só pelo interdito, mas, também, marcado pela contradição, declarado por emoções contrárias.

Nesse jogo estético, a linguagem sexual fomentada em todo o discurso de Mattoso, principalmente defendida no Manual, faz parte da ação conflituosa gerada por discursos transgressores em torno de questões pessoais do autor, cuja finalidade está em converter a dor em prazer, destituindo o politicamente correto pela prática discursiva e apologética à tortura e ao gosto singular por pés sujos. 


\subsection{A tortura consentida}

Em todos os tempos, os êxtases, as saídas de si próprio, têm sido uma forma de relembrar a força dessa sobre-vida. 0 mesmo ocorre atualmente. É sempre o outro de si mesmo que se exprime nos ruidosos transes de todos os tipos. Demoremo-nos um pouco nesse desdobramento fundamental. Só compreendendo sua estrutura poderemos entender os fenômenos extáticos (religiosos, esportivos, musicais) de que tratamos. Existe aí um ponto nodal absolutamente essencial e raramente analisado.

Michel Maffesoli - A parte do diabo

Aqui, já comentamos sobre o espaço que a tortura ocupa dentro da narrativa de Glauco Mattoso. Principalmente, relatamos como esse tema é retratado do ponto de vista voyerista do autor, em que a prática da tortura é convertida em prazer sexual daquele que consente e/ou observa.

De acordo com o dicionário Houaiss (1999), sadismo significa prazer mórbido em ver e fazer sofrer outra pessoa ou animal. (O sadismo é hoje considerado uma anomalia do instinto sexual, que impele à prática de atos de crueldade e até ao assassínio para atingir o orgasmo). Na mesma fonte, masoquismo significa "perversão sexual que leva a procurar o prazer na dor./Fig. Anormalidade daquele que tem prazer em torturar-se" (p. 1428).

Gilles Deleuze, em Sacher-Masoch: frio e o cruel (2009), discorre sobre a complementariedade e diferença entre Marquês de Sade e Sacher-Masoch, como literatos que apontam em seus textos o duplo gerado pela escolha da violência, numa configuração de conflito entre dor e prazer, provenientes do desejo humano, mas representados pela ideia de crueldade sobre a subserviência do outro e vice-versa. Entretanto, a nomenclatura criada a partir das obras dos dois escritores assume posições e linguagens diferentes. Para Deleuze,

...na obra de Sade as palavras de ordem e as descrições se superam, buscando uma função demonstrativa mais elevada;... repousa no conjunto do negativo como processo ativo de negação da Ideia da razão pura; ela opera conservando e acelerando a descrição, saturando-a de obscenidade. Na obra de Masoch, palavras de ordem 
e descrições se superam também, buscando uma função mítica ou dialética mais elevada; essa função repousa no conjunto da denegação como processo reativo e no suspense, como ldeal da imaginação pura. (...) A distinção fundamental entre o sadismo e o masoquismo vem à tona nos dois processos comparados: do negativo e da negação, por um lado; da denegação e do suspensivo por outro. (DELEUZE, 2009, p.37)

Em Glauco Mattoso, principalmente no Manual do polólatra amador, apesar da grande exploração de um comportamento masoquista empreendido pelo autor-narrador-personagem, o sadismo também está presente, tanto por parte de escolha daquele que narra, como proveniente do comportamento cruel de inúmeros personagens, configurando uma escrita sadomasoquista, desencadeada pelo processo de negação daquele que faz o outro sofrer, tal qual como da recusa daquele que se propõe sofredor, como trazido por Deleuze.

Suscitada em violência (tortura, bulliyng), a transgressão de Mattoso "transborda o interdito", em que "o jogo alternativo do interdito e da transgressão fica mais claro no erotismo" (BATAILLE, 2003, p. 95). Mas o erotismo glaucomattosiano é antropofágico e busca no discurso do outro (discurso literário) uma condescendência quanto às escolhas pautadas no texto (podolatria, por exemplo).

O canibalismo sagrado é o exemplo elementar do interdito criador do desejo: o interdito não cria o sabor da carne, mas é a razão pela qual o "pio" canibal consome. Encontraremos no erotismo essa criação paradoxal do valor de atração pelo interdito. (BATAILLE, 2003, p.95)

A sedução pelo interdito enquanto representado por uma linguagem possibilita, não só maior soltura em relação ao discurso, mas uma extensão consciente das mediações a propósito do corpo, do desejo, do prazer.

O gozo do autor-narrador-personagem está justamente na vivência, experiência, lembrança e imaginação da dialética da dor e prazer, como exercícios de um mal moral, colocados no espaço do proibido e cruel. Obviamente a representação imagética para a busca da realização do protagonista está na tortura, consentida ou não, vivida ou não, por aquele que narra. 
Qualquer dicionário traz o termo tortura como algo próximo do que indica suplício ou tormento violento infligido a alguém, bem como a ação ou prática de torturar o outro, extrapolando seu espaço de liberdade e dignidade, martirizando-o.

Para Glauco Mattoso, a tortura é a verdadeira representação de um sofrimento em que uma pessoa é imposta por outra, mas com o princípio único da ação cruel em detrimento de seu prazer em anulação do desejo da outra pessoa. Mais do que isso, é a invalidação da vontade de um pela simples realização do prazer do outro. (MATTOSO, 1986a, p. 29)

Luciano Oliveira, em Do nunca mais ao eterno retorno - Uma reflexão sobre a tortura (1994), explica que

\begin{abstract}
Quando Marx qualifica a feroz repressão que se seguiu à derrota da Comuna de Paris, de "indizível infâmia", ele não está simplesmente se valendo de uma figura de retórica, pois a expressão capta bem um dos aspectos mais curiosos da prática da tortura depois do seu restabelecimento nas primeiras décadas do século XX: a sua "indizibilidade". Com efeito, a negação da tortura pelas próprias autoridades que dão o sinal verde a seus torturadores - ou que, mais comodamente, nada querem saber do que se passa nos porões do regime - é um comportamento praticamente generalizado neste século. Mesmo os sistemas totalitários, que desdenharam - seja em nome de uma classe (o comunismo), seja em nome de uma raça (o nazismo) - o sentimento humanista, não tiveram a ousadia de assumir tais práticas publicamente. A exceção que confirma a regra provém, nos últimos tempos, do fundamentalismo pregado por líderes..." (OLIVEIRA, 1994, p. 67)
\end{abstract}

A ação da tortura em Mattoso é próxima daquilo que Michel Maffesoli chamará de animalidade em $A$ parte do diabo (2004). Tal qual Bataille, em $A$ parte maldita, Maffesoli fala da sabedoria demoníaca, cuja preocupação se baseia no reconhecimento de todas as coisas por uma violência totalitária, recorrente nas histórias humanas. Essa sabedoria é uma forma de reconhecimento dos limites da dicotomia entre bem e mal, de maneira a considerar o impossível de ser considerável, retornando àquilo que Bataille chama de interdito. A fragmentação do que pode ou não ser dito e vivido é do cotidiano e, desde a idade média, dividiu as esferas "oficial" e "não-oficial", delimitando discursos, vozes e espaços dominadores. 
A escolha de Mattoso para tematizar sua escrita sadomasoquista encontra no cruel a possibilidade do trânsito pelos espaços do que pode ou não ser dito e explorado. A tortura, neste aspecto, representa a iniciativa do autor perante ao contexto coletivo da época de publicação do Manual, apropriandose dos discursos sobre tortura durante o regime e reconstruindo-os de forma politicamente incorreta, destituindo, pela sua escrita, o poder dado aos torturadores - já que GM, no texto, deseja e busca pela tortura como forma de vivenciar seu prazer sexual.

O tema tortura foi bastante explorado pela literatura de cárcere em todo mundo, bem como de escritos pós-guerra e pós-ditatoriais. No Brasil, inúmeras são as referências em que esse tema é abordado, principalmente do ponto de vista daqueles que foram torturados.

Brasil: nunca mais (1985), texto organizado pela Arquidiocese de São Paulo e prefaciado pelo Cardeal D. Paulo Evaristo Arns, lançando um ano antes do Manual, é uma das principais referências quanto ao crime de tortura cometido pelo militarismo brasileiro durante o regime militar. Divido em seis partes (assim como o Manual, 2ª edição), o livro aborda, desde descrição de métodos de tortura ao sistema repressivo e os extremos vividos em situações de represália e restrição de direitos e liberdade.

O texto autoficcional de Mattoso, apesar de não fazer referência ao livro da Arquidiocese de São Paulo, possui certa semelhança quanto às descrições empreendidas sobre a prática de tortura, embora o enfoque dado por GM seja, ironicamente, por uma inversão do significado ocupado pela prática da tortura e narrada por um fetichista masoquista.

$\mathrm{Na}$ maioria das publicações pós-ditatoriais em que a tortura aparece como ponto de discussão, poucos se prolongam além do que foi exposto em Brasil: nunca mais. No geral, o ponto em comum entre eles está na referência aos DOI-CODI e nas demais casas de tortura e trazem o nome de Sérgio Paranhos Fleury como líder cruel e articulador dos movimentos de apreensão, tortura, morte e desaparecimento de corpos.

Quanto aos instrumentos dessa prática, quem vai descrever com um pouco mais de afinco também será o livro da Arquidiocese, juntamente com o introdutório $O$ que é tortura? de Glauco Mattoso, já apresentado aqui. 
Transitar pela história daquele período, bem como ter noção das discussões empreendidas nas publicações da época corrobora para a compreensão da construção do Manual pelo ponto de vista da tortura, principalmente por se compreender que, mais do que incorreto diante do que é politicamente aceito, Mattoso desconstrói o conceito de tortura ao assumi-lo como algo positivo para seu prazer pessoal.

Parece, a um primeiro momento, escarnecedor diante daqueles que, de fato, vivenciaram o período do Regime, bem como sofreram com a prática da tortura e exílio. Entretanto, a posição assumida pelo autor-narradorpersonagem do Manual não é entendida por nós como um deboche sobre quem sofreu, mas uma conversão de significados em torno da dor causada pela opressão de não usufruir das suas próprias escolhas, bem como da liberdade civil restringida dos brasileiros.

Para nós, o que merece ser trazido neste contexto é a forma como Mattoso expõe a tortura, narrando seu desejo em ser torturado para atingir o gozo sexualmente. No Manual, ao descrever detalhes sórdidos de episódios de suplício, vividos ou não por ele, desde sua infância à fase adulta, desloca o imaginário constituído no texto quanto à positividade do título, ao passo que instaura uma animalidade à narrativa, que extrapola os limites da significação enquanto discussão politicamente correta. Suas aventuras sexuais são representadas pela tortura de modo perturbador, reconfiguradas pela metáfora do pé e seu desejo pela dor e submissão.

A prática do bullying, bem como a busca pela vivência masoquista, são dois processos de experiência irônicos, trazidos no texto como maneira de desconstruir a dor por eles causada, a partir da satirização dos relatos e cenas remontadas em prol do desejo do autor-narrador-personagem.

Essa atitude masoquista, tomada por aquele que conduz a história, revela a denúncia do texto quanto à prática da tortura: Mattoso a naturaliza como algo bem mais comum do que se imagina, embora extremamente massacrante, que denigre o indivíduo à sua pior condição, destituindo-o de qualquer voz e poder e colocando-o como ser fragilizado diante daquilo que vivencia, sem escolha. 
Ao debochar da tortura, GM ameniza a força que ela representa, mas não como forma de defendê-la diante do outro, mas, sim, de converter a dor da humilhação e degradação em prazer e gozo daquele que sofre.

O livro aponta vários trechos em que se é possível perceber e reforçar o quanto esse processo é degradante, porém, escarnecido por Glauco:

\begin{abstract}
Sempre de quatro, de joelhos ou de cócoras, sem conseguir livrar o uniforme da sujeira, obrigavam-me a manter a boca aberta enquanto cuspiam e escarravam dentro; em seguida, mandavam-me engolir tudo duma vez. Faziam-me descalçar tênis e meias com a boca e chupar dedos chulepentos. Por fim, como desfecho previsível, forçavam-me a mamar em seus pintos ensebados e até a beber mijo, uma vez, quando a camisa ficou molhada e fedendo, restando-me em casa a desculpa esfarrapada de ter escorregado no banheiro da escola. (2006, p. 41-42)
\end{abstract}

Em três esferas diferentes, a tortura é trazida pelo autor e conduzida a uma reflexão diferenciada em cada prática: a primeira, do bullying na escola, descontrói a figura da criança como boa e ingênua; a segunda, do trote estudantil, explicita a figura do jovem inconsequente e aventureiro, cuja intenção nada mais é do que se divertir pelo processo de aceitação num novo grupo; a terceira, da tortura militar, que é consagrada como absurda e fere os princípios dos direitos humanos. Será que, somente a tortura cometida entre as quatro paredes de um sistema prisional é que representa essa desumanidade? $O$ instinto humano e sua configuração dicotômica entre o que é bom e ruim não estão dialeticamente em todos os espaços?

A reflexão glaucomattosiana vai além do que é socialmente aceito quanto à prática da tortura. Ela influencia a nós, leitores, repensarmos nossos conceitos quanto à crueldade e o sofrimento, mas também, os espaços do prazer com o sofrimento, haja vista que o ponto de vista é alterado de acordo com aquele que vivencia $o$ ato.

Para complementar a reflexão acerca dessa discussão, deixaremos aqui "Os dez mandamentos do torturador", escritos por Glauco Mattoso e publicados na revista Chiclete com Banana (fig. 40). 


\section{OS DEZ MANDAMENTOS DO TORTURADOR}

2. AMAR A DEUS

SOBRE TODAS

AS coIsAs

O torturador amu e é temente* a um đeus, sim senhor, Que đeus, tuão vem ato ciso. Mas ama, exceto que abaixo de deus as esti ele, rorturidor. Sim. pois para amar in deus conforme o mandimento, 0 torturador tem que estar acima de sodas as coisas e, por que nifo dizer, pessosis. F vendinde que, na priticts, o torturador nần convegre ser

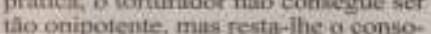
lo de poder ao menos pisar ita cara do lo de poder ao menois pisar na caru da
torturado e trepar-lihe no eorpo.

2 NĀO TOMAR SEU

SANTO NOME

"Santo name" eo caralho, "VTa" 6 a das nadegas. Ouer dizer: nho tomat no cu. Um auténtico torrumedor nunce toma no cu, nem no scritido proprio. nem no figurado. Quem tama $t$ o torturade

- guardar

DOMINCOS E

- FEsTAS de guARda.

Isto e, o domingo ea fenta de guanda Găo as dias de folisa der torturndor, que ninguèn ó de ferro, exceto o tortunt do. No domingo todo mundo descan sa, exceto o forturado e os guardas de plantato. Estes subatituem os torturadares de folga of farem a festa. Daí dares de folga e fazem a fenta, Dai a modo, matamise trü coelhosr o tor. turador aproveita para cocar o saco, e us guardis para tirar sua cisquinhat. O terceits coetho es torturado.

\section{Honвa月}

IPAIEMAE.

Fxceto, naturalmente, os puis do torturado. Eistes podem ser of sondide monal $e$ ale fisicatnenfe, se necessi. rio*" na. presencia do torturado.

\section{D. $N$ NO MATAR.}

Unt corturador rumear mato. O torturado sempre se suicicta, e atropelado as teritar funir, ou atvejado em tiroteio ou juaticado pelos companheiros de priasa. Elqueci de alguma outra sada?

\section{PNÁO PECAR}

C.NTRRA

- CASTIDADE

Um forturautor de respeito nunca per

tica violencias sexuais contru pessoas virgens, Isto porque toda torturado ji perdeu o cabaco no cangaco, ou en tho no cagaco da tortura. Portanto, o torturador so peca se poupar o tortu. rado do estupro.

\section{Nã̃ furtar.}

Torturadisr piedoso nfo furna net um grampinho de sua vitima. Esper primeiro que esteja inapelavelmen. te finadu $c$ o objeto em gueatdo nao possa ser teclamado Ai já nato é mais urto, conecirda'

náo levantar

Falso

TESTEMUNHO

Nem pensar Um verdadeirs torturador nto falseia nada, Sequer aventa. O próprio torturado se encarrepa de Propro tomarado se cnicarrega de rorm, responderlas e assinat embaixo. Ao torturador cabe apenas estimular a lingua do sujeito.

\section{- NÁ̃o desejar A MULHER}

Do PAOXIMO

Forturador nito precisa desejar a muther de niniguem. O torturndo esta al pra isso: servir de mulher, netm que pra tsso: servir de mulher, netr que seu cu e com sua boen e, se o, torturador achar que nilo basta, servir de. muther de malandro, de capache o. ate de amarelinha.

\section{Nào cobiçar altheitis. \\ Magina. Se um tortunidor năo furta. conto é que vai sequer cobicar alge que ainda nầ libe pertence? Jar aligo escrito que o bom torturndar espera até que o pertence nalo tenha mail dono, o to entâto dele se apropria. Maito justo. Afinal, depois de tanto trabalho ingrato e inglório. E aind tem gente que vem com papo do que crime conore nâlo abrange a pritiea crime cont Cone

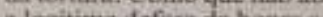 o marito. mide é que fica? \\ (4) Cf THKOTHKO Aqwimalab rementer ef gemuraix, ow Qhism nalo

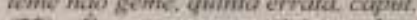 (F) E semper necessario, emhor

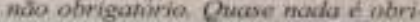 satcinio pang wom torturador Sotorto-

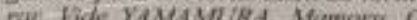

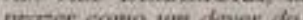

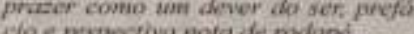 who e respectiva nota de nodand}

Figura 40. Glauco Mattoso e Os dez mandamentos do torturador, publicado na revista Chiclete com Banana (№ 3, 2007)

Ironicamente, Mattoso reescreve os dez mandamentos bíblicos como forma de dar ao torturador toda a força e poder por ele almejados, quando se tem, diante de si, um indivíduo desprovido de qualquer vontade. O primeiro mandamento, associando o torturador a Deus, descreve a personalidade 
dominadora daquele que submete o outro ao suplício. É o mandamento maior do poder existente nas mãos do torturador: uma onipotência inabalada pelo torturado, já que este está em posição de humilhação e subserviência.

Os mandamentos 2 e 6 despertam para as práticas de abuso sexual sofridas durante o processo de tortura. A nudez, primeiro passo para a violação do corpo, desnorteia o torturado, dificultando reações contrárias às práticas da tortura física enquanto contato forçado com os orifícios. Nos mandamentos, Mattoso ironiza as ações do abuso, demonstrando o cinismo da conduta do torturador na ação da violência sexual.

O autor também aponta o quanto a violência verbal está presente no processo de tortura, por xingamentos chulos e desrespeito moral daquele que se encontra nas mãos cruéis dos deuses da tortura. Os praticantes também são isentados de culpabilidade diante daqueles que morrem durante as sessões de tortura. Afinal, diz Mattoso, torturador nunca mata.

No 9o mandamento, ainda munido da ironia paródica, o autor traz a feminilidade com um olhar machista, conduzido pelo discurso de que, transformar o torturado "homem" em "mulherzinha", é colocá-lo na situação de sujeito fraco, servil, de fácil manipulação e entrega.

O último item da lei reafirma todos os outros e conduz à compreensão de que o torturador está à espera daquilo que the chega às mãos. Isso o coloca, novamente, na posição de isento de culpa e escolha. É ele alguém que age porque precisa agir, de modo "justo" e "honrado".

A crueldade da tortura como paródia de um texto religioso, cujas semelhanças vão para além das leis divinas, reforça, ironicamente, o discurso de que existem justificativas para atos desumanos. Glauco Mattoso ocupa-se de voz literária para se aproximar desses discursos, ridicularizando-os enquanto prática necessária e aceitável. Coloca diante do leitor a crueza das ações humanas, mediadas pelo falso invólucro da justiça e racionalidade.

Em Mattoso, entende-se que a tortura não é só uma prática desumana, conduzida (veladamente) por instâncias dominadoras como necessária, mas ela é escolha, é do sensível e traz prazer àquele que opta pela dor e desprazer do outro. Eis a maior e mais injustificável de todas as desumanidades. 


\subsection{Abjeção e coprofagia}

Soneto para a "Cegueira ordeira" (XI) [2569]

"Salivo-Ihe nos bagos, levemente, até que ele se sinta satisfeito e mande retornar, com calma e jeito, à rola fedorenta e repelente."

"De novo, aquele sebo! Não contente que eu lamba e engula aquilo, esse sujeito me faz mostrar a língua. Tem efeito hilário o gesto: alegre ele sente!"

"Sarcástico, gargalha, ao ver que minha linguona recoberta está de massa já meio diluída, amarelinha."

"Então eu recomeço. Ele acha graça se, quando uma lambida Ihe esquadrinha a glande, eu de enojado cara faça."

Glauco Mattoso - Cinco ciclos e meio século

A definição de abjeção é procedente dos estudos da teórica e psicanalista francesa Julia Kristeva, em seu livro Pouvoirs de l'horreur (1980). Kristeva depõe sobre um sujeito que busca, pela linguagem, aquilo que é posto de lado e ignorado pelo contexto social, principalmente quando ligado às questões do humano, que são negadas e negligenciadas.

A palavra abjeção tem origem latina 'abjetum', cujo significado é baixeza, aviltamento. O termo também sintetiza aquilo que deve ser desconsiderado, jogado fora, excluído por ser nojento, deplorável e imundo.

Kristeva permite-nos pensar na abjeção como a lacuna entre o significante e significado, que se utiliza da linguagem para dizer o indizível. Para a teórica, quem dá conta dessa lacuna é o conceito de desejo defendido 
Jaques Lacan, que o define como falta ${ }^{65}$. A partir do ponto de vista da semiótica, Kristeva pensa na abjeção como espaço de limbo entre o processo linguístico de significação das coisas. Para ela, abjeção parte dos princípios da castração e sublimação freudianas.

Em Glauco Mattoso, embora cientes da grandeza desse viés de análise, não abordaremos a questão do desejo como falta, no sentido lacaniano, nem como o processo de sublimação freudiana por meio da arte, haja vista que nosso propósito não é um estudo literário pelo viés psicanalítico, mas estético. Novamente, aqui a pretensão está em compreender o processo consciente e sensível de criação do autor denunciados pelos textos literários e seus elementos. A proposta maior está em trazer à tona o conceito de abjeção como possibilidade de expressar o não-dito, de buscar nos espaços negados socialmente, toda e qualquer significação que possa ser representada pela arte. A criação literária de Mattoso traz a palavra negada para o espaço primário, encarando o efeito gerado pelo impacto de sua escolha abjeta, assumindo funções e desejos do corpo como enfrentamento da angústia da condição de cego.

Segundo Hegel,

São mais estreitas as relações entre o sensível e a vida interior do homem, a que também se pode chamar espírito. O aspecto natural do espírito, ou o sensível, existe para o desejo. Temos precisão de objetos exteriores que consumimos e para os quais nos comportamos de um modo negativo. A relação estabelecida pelo desejo é a de um individual para um individual, é uma relação em que o pensamento não interfere e que não provém de uma determinação geral. $O$ individual perante o individual só se conserva mediante o sacrifício do outro. O desejo devora, pois, os objetos, caso em que não existe nada mais do que um interesse isolado. Os objetos a que o individual se refere são sempre individuais, concretos (...) (HEGEL, 2009, p. 56)

O espírito consiste na consciência que constitui a aparência dada ao objeto de arte, pelo processo de manifestação sensível da ideia. O processo de criação por uma representação abjeta é transgressor, pois não respeita os limites e se propõe ambíguo e paradoxal. Para Kristeva, "Ce n'est done pas l'absence de propreté ou de santé qui rend abject, mais ce qui perturbe une

\footnotetext{
${ }^{65}$ Conceito bastante complexo e não desdobrado nesse espaço de discussão.
} 
identité, un système, un ordre. Ce qui ne repecte pas les limites, les places, les règles. L'entre deux l'ambigu, le mixte." (1980, p. 12)

A linguagem abjeta proposta por Kristeva tem relação com o critério da diferença, cuja exploração se dá por meio do rompimento com o harmônico estético, desestabilizando critérios de contemplação do objeto. Nesse contexto, não é necessariamente a ausência de critérios de higiene, mas o desconforto trazido pela sua representação de sentido, indicado pela fragilidade dos significados e exploração da linguagem pela arte. Kristeva pensa o abjeto como algo que obriga, por um momento ritualístico, a construção simbólica da margem em relação ao legítimo.

Em Glauco Mattoso, entendemos que falar de abjeção é trazer a coprofagia como conceito de construção semântica em seu processo de escrita escatológica. O termo, já comentado anteriormente neste texto, surge com a criação do JORNAL DOBRABIL, e representa uma satirização da antropofagia oswaldiana, cujo princípio partiu da aglutinação da cultura alheia para formulação e representação da própria cultura. Já a coprofagia glaucomattosia tem como proposta um processo proveniente da ação abjeta de recolher o que foi excluído culturalmente. Mais do que isso, de representar literariamente a mistura e influência direta daquilo que é lançado a nós, como forma de apropriação do discurso e da criação do outro. Podemos dizer que a coprofagia funciona pelo intertexto, pela apropriação e pela abjeção.

\begin{abstract}
Além da cegueira que a atormenta e da podolatria que a alimenta, a poesia de GM tem sido rotulada de escatológica. Com efeito, desde a fase anterior à cegueira 0 poeta reciclava satiricamente a "antropofagia" oswaldiana, introduzindo o conceito de "coprofagia" para simbolizar o reaproveitamento de rejeitos (ou seja, a revalorização de informações contraculturais e comportamentos antisociais) que caracterizaria a pós-modernidade em sua faceta mais radical e marginal. Já em poemas setentistas como os manifestos "Escatológico" e "Coprofágico" GM antecipava o sarcasmo agora revelado em toda a plenitude nos sonetos, onde a forma burilada serve de crivo fino para a mordacidade temática metaforizada pela merda: passa-se em revista, através do resíduo digestivo, desde a denúncia da tortura (veja-se o ciclo "Coprofagonia" em página à parte) até os mais nobres e elevados valores éticos ou estéticos do espírito humano. Segue abaixo uma amostragem dos sonetos de teor explicitamente coprológico dentre as centenas que GM publicou ou ainda mantém inéditos.(MATTOSO, 2003) ${ }^{66}$
\end{abstract}

\footnotetext{
${ }^{66}$ Roteiros Online < http://www.roteirosonline.com.br/escatologico.htm>
} 
O termo ganha reforço em sua representação a partir da publicação de dois manifestos, em que a abjeção, representada pela "linguagem de mictórios", conduz a significação expressa pela escrita poética, sarcástica e paródica dos textos.

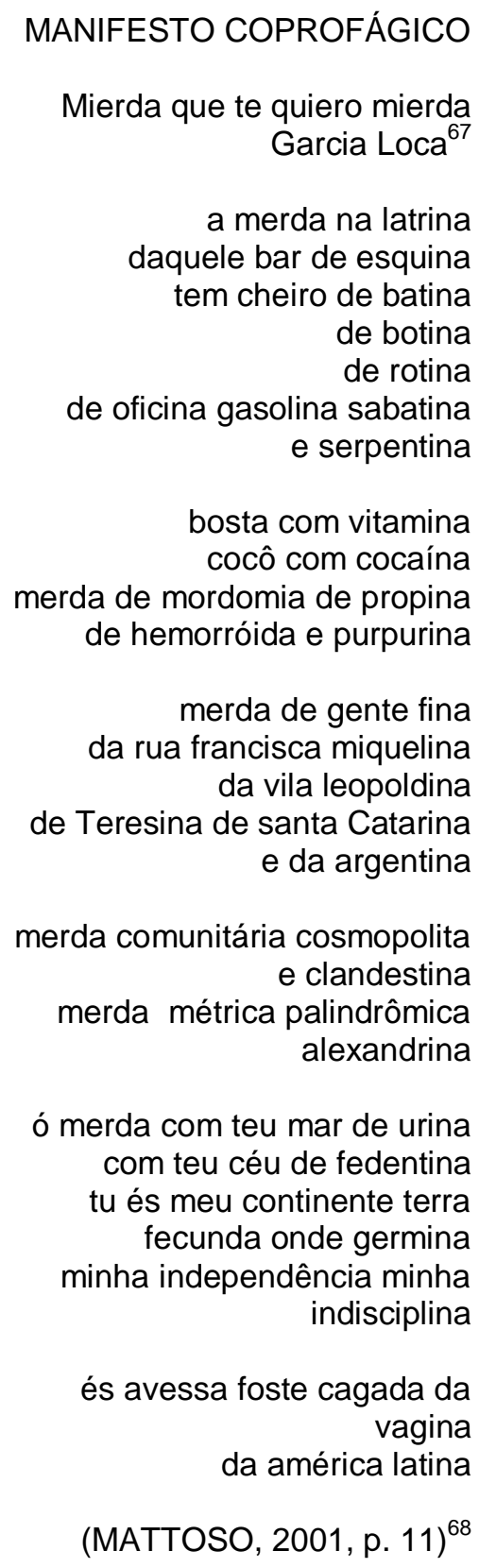

\footnotetext{
${ }^{67}$ Heterônimo colaborador do JD.

${ }^{68}$ Seguindo o alinhamento, à direita, que está no JD.
} 
Eh! home, bosta de Deus!

(MARIO DE ANDRADE)

O homem é o único animal que caga por vontade própria.

Cagar é uma das quatro finalidades do ser humano. Não me lembro quais são as outras três.

Os direitos humanos chamam-se, pela ordem, fome, caganeira, tesão e sono. A liberdade de pensamento vem depois, isto é, no dia seguinte.

A merda e o pensamento são a matéria da filosofia.

$\star \star \star$

Em verdade, em verdade, vos digo: a merda é branca, porque tudo é branco.

No princípio, era a merda.

$\star * \star$

La mierda es como la luz: una y varia; y como la naturaliza: uma y fecunda; y como Dios: una y inmensa.

$\star \star \star *$

A merda é doce e amarga. Quando é doce, ofende. Quando é amarga, excita.

Cagar é uma atividade do espírito. Porém, como o pensamento, não passa duma reação química. $* \star *$

O mecanismo do pensamento é constituído de dados enciclopédicos: a repleção do cólon sigmoide é seguida de uma invaginação deste no reto; há a abertura do esfíncter reto-sigmoidiano e a evacuação sigmoidiana no reto. $O$ peristaltismo retal envia as fezes para 0 esfíncter anal. Há, concomitantemente, aumento da pressão intraabdominal por contração do diafragma e dos músculos abdominais. Comando nervoso. Reflexo: estímulo é a distensão retal; centro: medula sacra e assoalho do quarto ventrículo; fibras motoras; parassimpático hipogástrico. Mas o reflexo pode ser controlado pela vontade.

Assim na terra como no cu.

(MATTOSO, 2001, p. 11)

Ao reaver e até contrariar uma estética como a modernista, já canonizada no espaço da arte e da literatura, Mattoso se propõe contemporâneo, da forma como nos faz pensar Giorgio Agamben, em O que é contemporâneo? (2009).

Essa especial relação com o passado literário tem também um outro aspecto:

\footnotetext{
${ }^{69}$ Nos dois manifestos, há, explicitamente, citações atribuídas a um heterônimo do JD, Garcia Loca (referência ao poeta espanhol Garcia Lorca) e a Mário de Andrade.
} 
De fato, a contemporaneidade se escreve no presente assinalando-o antes de tudo como arcaico, e somente quem percebe no mais moderno e recente os índices e as assinaturas do arcaico pode dele ser contemporâneo. Arcaico significa: próximo da arké, isto é, da origem. (AGAMBEN, 2009, p. 69)

Para o filósofo, a contemporaneidade está ligada à temporalidade da moda, instituída e destituída pelo tempo, numa singular inquietude do poder. Paradoxalmente, liga-se ao passado e retoma-o, seja para desconstruí-lo ou reformulá-lo a partir da subjetivação da linguagem e interpretação assimilada do discurso anterior.

Dessa feita, Mattoso se propõe transgressor e, por construções linguísticas abjetas e escatológicas, (re)constrói sua estética, reformulada em representações anteriores, mas satirizada pelo intertexto.

Pensar a estética de Glauco Mattoso como uma transgressão implica evocar os estudos do professor e pesquisador estadunidense Steven Butterman, em que chamará de anti-estética a escrita do escritor brasileiro, ao escrever seu livro Perversions on parade: Brazilian Literature of Transgression and Postmodern Anti-Aesthetics in Glauco Mattoso (2005), fruto da sua tese de doutoramento.

Butterman faz um panorama pela obra de Mattoso, passando por alguns de seus principais livros, a fim de compreender o curso poético do autor, desde suas influências literárias e estéticas à escrita fetichista e transgressora. Ele se aprofunda na ideia de uma sexualidade transgressora defendida por Mattoso, por meio dos estudos de Georges Bataille, Judith Butler, Deleuze e Freud, compreendendo o universo sadomasoquista explorado por GM em sua trajetória de escritor.

O livro de Butterman sobre a obra de Mattoso é, até o momento, a única referência crítica publicada, complementando algumas poucas teses de doutorado e dissertações de mestrado, como parte da fortuna crítica de Glauco Mattoso. Entretanto, a abordagem do norte-americano sobre alguns detalhes da escrita glaucomattosiana, divergem de algumas das defesas feitas nesta tese. Dentre elas, destaca-se nossa defesa de que o Manual do podólatra amador é uma autoficção e não uma autobiografia, conforme acreditava 
Butterman; bem como a ideia de que Glauco Mattoso é uma construção heteronímica, em que a figura do autor existe a partir do discurso que ele sustenta, e não um pseudônimo - atribuição legitimada por alguns estudiosos.

Também chamamos de antiestética a escrita coprofágica de Mattoso, adjetivo já impresso tanto por Butterman, bem como por Foster. Contudo, direcionamos a questão da estética para um viés analítico da obra de Mattoso a partir do conceito de kitsch, desdobrado pelo escritor tcheco Milan Kundera, comentado a seguir.

\subsection{O kitsch como um mal ético e a merda em GM}
"O kitsch é o mal no sistema de valores da arte."

Hermann Broch

É notório que o que se destaca na escrita glaucomattosiana, mais que seu conteúdo de temáticas irreverentes, é a releitura da antropofagia a partir do que entendemos ser uma desconstrução da ideia de kitsch, onde a merda se torna elemento central da significação do homem, representado pela linguagem: "A merda é mais universal que o Esperanto. As bocas têm muitas línguas; o cu apenas uma." (MATTOSO, 2001, sem indicativo de página).

O kitsch é uma falsa harmonia. É uma falsa arte para um fim estético. Contrariá-lo é assumir a desarmonia, é assumir, num viés glaucomattosiano, a coprofagia.

Consultando o dicionário literário, a definição de kitsch aponta como termo de origem incerta:

... surgiu por volta de 1870 no comércio artístico em Munique para designar objectos de arte, feitos de propósito para satisfazer a procura de uma nova clientela endinheirada. A partir deste contexto, a palavra evoluiu pejorativamente no sentido genérico de arte de imitação e de mau gosto. Kitsch é um termo internacional e aplica-se em todos os domínios da produção artística, desde as artes plásticas até à literatura, música e artes decorativas. ${ }^{70}$

\footnotetext{
${ }^{70}$ Disponível em:

http://www.edtl.com.pt/index.php?option=com mtree\&task=viewlink\&link id=79\&ltemid=2
} 
Umberto Eco, em Apocalípticos e Integrados (1976), traz a ideia de kitsch como uma forma pomposa de "uma cultura de massa e de uma cultura média, e consequentemente, de uma cultura de consumo." (1976, p.73) O escritor comenta a estrutura do mau gosto, trazendo, dentre alguns autores, Hermann Broch, como um dos formuladores do conceito de kitsch, o qual defende que é impossível a arte existir sem a presença do kitsch. Segundo Eco, Broch defende que essa estética é o

\footnotetext{
..que produz efeito naqueles momentos em que seus consumidores desejam, efetivamente, gozar efeitos, ao invés de empenharem-se na mais difícil e reservada operação de uma fruição estética complexa e responsável. (ECO apud BROCH, 1976, p. 74)
}

Já de acordo com Milan Kundera, em seu romance $A$ insustentável leveza do ser (2008), kitsch é uma palavra alemã "que apareceu em meados do sentimental século XIX e que em seguida se espalhou por todas as línguas. Mas o uso freqüente do termo apagou seu valor metafísico original." (KUNDERA, 2008, p. 244)

Nossa compreensão do valor metafísico dado ao kitsch por Kundera dialoga com aquilo que Arthur Schopenhauer discorre em Metafísica do Belo (2003), em que a metafísica, como expressão da vontade, dá-se pela representação racional do sensível, que busca dar forma e compreensão a essa vontade, ao passo que também é modificada por ela.

A definição do kitsch trazida por Kundera é a que mais se aproxima da ideia da desarmonia estética construída por Glauco Mattoso, pois, sua escrita aponta aquilo que é abjeto, logo, negado e ocultado, transgredindo com as possibilidades de eufemização e harmonia, esteticamente presentes na escrita literária kitsch, em que a estrutura romântica dá forma, cuja pretensão é proporcionar o efeito estético agradável. Mattoso contraria esse processo e desestabiliza o espaço de estilo da arte literária enquanto objeto aprazível, para algo incômodo e categoricamente marcado pela presença da merda.

Antes de nos adentrarmos no espaço da "merda", propriamente dita, voltaremos ao conceito de kitsch a partir do que pensa Hermann Broch, a fim 
de traçarmos o caminho para se compreender o porquê de afirmarmos que Mattoso é um "antikitsch".

Para o senso comum, quando se fala em kitsch, pensa-se, não só na arte, mas em algum objeto de mau gosto, brega e até inútil. Seu conceito geral está muito mais próximo do produto, do designe, que, especificamente, da arte literária enquanto objeto artístico, desconsiderando seu processo.

Lipovestky e Serroy (2015) vão tratar desse fenômeno como a lógica da competição e do excesso, cujo avanço estético se realiza no kitsch.

Abraham Moles, em $O$ Kitsch (1972), trata da gênese desse conceito como exemplo de alienação por meio de sua inserção e seu funcionalismo na forma de vida do indivíduo. Para ele, o kitsch deixa de ser um "valor" ou atributo artístico para ser um valor estético. Moles aponta essa estética como caráter de consumo, haja vista que a essência do kitsch está nas coisas, enquanto objetos, associada a uma "arte da felicidade". Existem três distinções tipológicas do kitsch, aponta Moles: as situações kitsch (arte religiosa, arte de apartamento, decoração, etc.); os atos kitsch (industrialização de souvenir, artesanato); e os objetos kitsch (sedimentares, transitórios, permanentes) (MOLES, 1972, p.50-51). Em todos os tipos, o objeto, enquanto coisificação kitsch é questão central de Moles. Reduzir um conceito ao objeto concreto e simples faz da estética kitsch uma característica de estilo.

Moles tem o kitsch também como uma "maneira de ser" (1972), já que acontece por um fenômeno social e cultural. Walter Benjamin (1994) e Theodor Adorno (2002) abordam o conceito em seus estudos sobre indústria cultural, ambos compreendendo que esse sistema estético também é oriundo de uma nova sociedade capitalista, cuja arte não mais é componente da "aura", defendida por Benjamin, mas saciadora da cultura de massa.

Hermann Broch, em Espírito e espírito de época - Ensaios sobre a cultura da Modernidade (2014), contextualiza historicamente o advento do kitsch a partir do final do século XIX e início do século $X X$, momento marcado pelo processo da revolução industrial e tecnológica. Nesse mesmo tempo, a arte deixa de pertencer à religião como sua principal fruidora e legitimadora, caminhando em direção à ideia de "arte pela arte".

$\mathrm{Na}$ tentativa de expressar a ética daquele tempo, a arte começa a ganhar autonomia e a exigir um espaço único no verdadeiro e absoluto, 
revisitando os conceitos e valoração, antes emitidos, antes, pela Igreja. Durante séculos, a humanidade viveu um contexto de obrigação e anulação de si sob os dogmas da religião, submetendo-se aos seus preceitos, valores, técnicas e conformidades. A autonomia, intensificada pela ideia de arte pela arte, registra um novo sistema de representação, cujo efeito, não mais definido pela lgreja, passa exigir um resultado além do estético: o harmônico.

\begin{abstract}
Quando se fala em perda de validade da arte, contempla-se apenas um dos polos, o polo do bem, ou seja, aquele conceito de arte conforme foi compreendido - aliás, compreendido com razão - ao longo dos séculos. Pois, em épocas de posturas de valores isolados, com mais facilidade do que em um presente que sucumbiu à anarquia de valores, com mais facilidade mesmo que a tensão entre os polos do bem e do mal tenha sido substancialmente menor. Sabia-se o que devia se entender por arte, e o que se entendia por arte era boa arte.(...) No entanto, o mal na arte é o kitsch. $(\mathrm{BROCH}, 2014$, p. 11)
\end{abstract}

Embora a arte firmando esse compromisso com ela mesma, os sistemas de valores empregados ainda estavam pautados no princípio do Belo (beleza ideial) e harmônico, cujas metas de exigência do estético passaram a exigir valores automáticos, manipulados, e principalmente, irracionais - haja vista que a assimilação e interpretação da arte não eram condições para se vivenciá-la, numa tentativa de anulação do conflito e de reflexão daquele que experiencia a obra de arte.

Para Broch,

.... estético, de modo geral e como expressão da mais elevada meta de valores de um sistema, pode apenas dar entrada na condição de efeito secundário automático no resultado da ação ética, exatamente como a "riqueza" não é o objetivo principal, mas sim o efeito secundário da ação comercial isolada. (BROCH, 2014, p. 21)

Mais do que um fenômeno de exigência e validade geral, a arte em consonância com a ética ampliava o valor no trabalho bem feito como forma de alcance legítimo do Belo, em que a técnica é convertida em um valor de bem. O estético, como expressão mais elevada enquanto valor artístico passa a não ser mais o foco, mas sim, o efeito estético que o objeto causa, passando-se a pensar a arte a partir do que ela pode causar e não ela em si mesma. Valores éticos encobriram a consonância de uma arte autônoma, impedindo-a de ser 
verdadeiramente livre enquanto criação, contemplação, experimentação e transformação.

A partir da interferência na manipulação do efeito estético, começa-se uma imposição ética de valores, por meio da arte.

\begin{abstract}
Mas o que significa aquela exigência feita à arte de trabalhar "bem" e não "belamente"?(...) como essa ideia de autonomia o valor assumiu uma irmandade tão estreita com a verdade, a ponto de 0 desenvolvimento autônomo do sistema de valores carregar o selo de uma veracidade interna, pode-se defender muito bem a opinião de que a verdade na obra de arte possui uma importância que no fundo foi sempre imaginada: trabalhar "bem" deve poder ser o posto em relação determinada com o caráter de reconhecimento da arte, com aquela revelação de novos conhecimentos e novas formas de ver e observar, que empresta não apenas às artes plásticas ou à poesia, mas inclusive a todo o âmbito do artístico o caráter de conhecimento geral. (BROCH, 2014, p. 22)
\end{abstract}

A ideia de bem ético como valor passa a representar um trabalho bem feito pela técnica, logo, pelo racional, em que se é possível construir uma estética harmônica (dentro dos princípios do Belo, num contexto ainda clássico), cujos valores carregam em si a ideia de verdade universal. A necessidade subjetiva de, por meio da obra de arte, resolver seus conflitos, é explorada de modo categórico em busca de uma satisfação que não é objetiva, mas libertadora e confortante, dentro de um espaço legitimado como verdadeiro. Por esta razão, segundo Broch, a arte passa ser, então, um elemento de valor. Quando definida como arte, logo é valorizada e categorizada. Isso a converte em acessório estético, em que elementos da realidade são esteticamente trabalhados e convertidos em algo dotado de valor eticamente aceitável.

Dialogando com Lipovetsky e Serroy (2015), a estetização do mundo como forma de organizar as relações sociais pela arte gerou um comportamento pautado numa sociedade capitalista, em que a arte deixa de ter um fim em si mesmo e passa a ser um adjetivo. Dessa forma, o hiperconsumo de objetos artísticos (inclui-se aí, comida gourmet, restaurantes, lojas e espaços "artisticamente" trabalhados, tal qual roupas, celulares e objetos diversos) dá existência a um ser "drogado de consumo", exigente de efeito 
estético, devorador do descartável e desejoso de divertimentos e alegrias efêmeras.

A liberdade criativa exigida não é livre, pois está ligada ao sistema de valores o qual repercute, pois “... é o pensamento de sistema próprio que domina qualquer sistema de valores" (BROCH, 2014, p.24). Dessa forma, criase a necessidade de trazer o subjetivo e o onírico para a realidade dentro de um pensamento de sistema representado harmonicamente. Os séculos XX e XXI não buscam nos objetos de consumo uma reflexão dolorosa sobre questões da condição humana, mas uma utopia de valores universais eticamente construídos, provocadores de boas sensações.

Entretanto, afirma Broch, o estético busca a arte pelo ético, já que a obra é absoluta, confortando no visível o invisível, permitindo o trânsito livre entre presente, passado e futuro; entre o conservador e o revolucionário. Mas o valor está ligado ao ético e, independente de qual sistema de valoração ele parta, sua intenção é buscar um infinito e absoluto, pois os princípios éticos querem partir de absolutismos. Porém, nada é absoluto e finito, já que as coisas tendem ao infinito e, consequentemente, à pluralização. O ético passa a ser constituído pela busca e necessidade desse absoluto, embora envolto de negações, justamente para restringi-las. Dessa feita, ter-se-á o domínio de sistema de valores pautados em sistemas éticos e determinantes da arte no início do século passado, condutores do papel da arte no tempo presente.

A busca pelo desvalor, ou pela autonomia de valores, definidor de cada sistema, passa a determinar o que é bom e mau, mantendo a lógica ética de sistemas de valores verdadeiros pautados em princípios morais e definidores do maniqueísmo bom vs. mau. Contrapondo, a estética como elaboração por meio do sensível, cuja pretensão se baseia na busca de liberdade e autonomia, sua representação acaba sendo construída em um sistema de valores externos, impedindo qualquer movimento livre de sua realização e experiência do sujeito.

Quando não é o artista que se embasa nesses sistemas de valores, é o expectador quem faz essa captação e joga para dentro do seu sistema individual de valor (um sistema compreendido por ele como absoluto e infinito, logo, verdadeiro), toda sua relação sensível com a obra, reivindicando validade única e universal. Ao que fica fora do sistema, não se pode atribuir juízo de 
valor (embora se busque sempre o enquadramento); ou seja, àquilo que não é atribuído um valor, é definido como algo de desvalor, gerando, segundo Broch, uma guerra de sistema de valores isolados (2014, p. 30).

Dessa forma, a autonomia passa a ser condicionada por estruturas,

\begin{abstract}
A intervenção na autonomia: essa formulação do "mal" é independente da natureza conteudística do respectivo sistema de valores, ela é meramente condicionada pela estrutura, e se a intervenção no comando autônomo de um sistema de valores pode ser caracterizada como a essência do "dogmático", o dogmático é o "mal” por excelência. (BROCH, 2014, p. 31)
\end{abstract}

Para Broch, o mal é o sistema oposto ao sistema de valores determinados e impostos. Mesmo sendo o oposto, ele não é externo. É só o contrário e depende do sistema de valores para existir. O mal, o contraditório, não é oposto do absoluto, do valor verdadeiro, pois um está no outro.

Esse movimento gera a inversão do que é ético em estético, pois exige da estética um efeito, em que a ética deixa de ser um conhecimento de valor e passa a ser representação estética. Enquanto sistema de valores, a ética é infinita e verdadeira; enquanto estética, é finita, representada no plano material.

Quanto ao efeito estético, na arte, busca-se uma meta infinita. "o verdadeiramente estético", o sensível. Automaticamente, busca-se alcançar a meta infinita por meio de um "bom" efeito estético. Nesse contexto, o irracional na arte acaba sendo levado pelo efeito, ao racional, e próximo eticamente do contemplador. A liberdade e a autonomia partem de valores falsos, moldados a partir de um passado sistemático de valores. Consequentemente isso pede uma exigência estética que caminha ao encontro da arte kitsch.

\footnotetext{
...a "exigência" estética se fundamenta naquilo que foi, no passado por excelência, que ela transforma em meta de valores, a uma meta de valores "falsa", que ela eleva a um sujeito de valores falso, a um anti-Deus, portador do mal, cujas exigências antiéticas intervêm no desenvolvimento vivo de um sistema original e em sua liberdade autônoma. E justamente por ser a "exigência estética" que assim repercute, é que o kitsch é convocado, na condição de fenômeno estético em sentido estrito, a se tornar representante do mal ético. (BROCH, 2014, p. 37)
} 
O kitsch como a representação do mal ético é dogmático e arbitrário e traz para o efeito a finitude da representação, que está diretamente ligada a sistemas de valores universais, e não individuais. O kitsch parte do efeito estético para um efeito ético do mal (o ético dogmático, definido, completo, restrito), tornando-se, em partes, tendencioso e engajado. Broch afiram que "a essência kitsch é a troca categórica pela categoria estética" (2014, p. 40), em que o que importa é o belo efeito causado pela arte kitsch e não o objeto em si.

Compreende-se que, para Broch, o kitsch busca elementos repetidos, enquanto forma de imitação, mas evita uma reflexão profunda de aspectos da condição humana, principalmente em consonância com um passado (nostálgico) e um futuro (idílico). Ele é o mal ético porque imita uma representação de valores e foge para esse idílio-histórico, espaço irracional de sensibilidade imediata, ausente de reflexão e enfrentamento. Dessa forma, tem-se o kitsch como total anulação do passado e do futuro, numa troca do finito pelo infinito.

Na sua fuga para o irracional, o kitsch converte sua estética em ética, dominado por sistemas de valores dogmáticos, ditados por algum discurso emergente: religioso ou político, por exemplo. Dessa forma, ele é conduzido à satisfação dos instintos, numa busca eterna pelo harmônico, porém, imitando elementos e manipulando-os, num movimento de conforto na relação entre a obra e aquele que a aprecia. O mal do kitsch não é a negação do bem, mas sua imitação. A imitação acaba por se tornar uma ação destoante, já que rompe com o ético e, paradoxalmente, torna-se mal por excelência, mas, em contrapartida, exerce sua principal função: a manipulação do efeito estético.

Mas o que seria a merda no contexto da criação artística/literária? Dirá o heterônimo de Mattoso, Pedro o Podre: "A merda dos grandes homens é sempre maior, mais fedida e, o que é pior, acaba entupindo a privada." (MATTOSO, 2001, sem indicativo de página).

Para nossos estudos, calcamos na relação da merda com o kitsch enquanto ligado à criação literária. Segundo Maria Veralice Barroso ${ }^{71}$, Kundera reflete sobre o kitsch a partir da merda como possibilidade de reflexão de

\footnotetext{
71 Defendeu em 2013, na Universidade de Brasília, sua tese de doutoramento A obra romanesca de Milan Kundera:um projeto estético conduzido pela ação de Don Juan.
} 
questões do humano que só podem ser traduzidas através do romance (2013, p.71) - para nós, através de qualquer manifestação artística.

Para Kundera, a "merda" é tudo o que é humano. Desse modo, o escritor enfatiza a dicotomia entre o ser humano e o criador; entre o perecível e o eterno. Enquanto Deus é a perfeição, já que é responsável e tem o domínio de tudo o que cria, também provoca "a incompatibilidade entre a merda e Deus" pois, se o Homem é a imagem e semelhança de Deus, ou Deus tem intestino e defeca ou o Homem não se parece com Deus (2008, p.241). E quem assumirá um deus que "caga"?

\footnotetext{
A merda é um problema teológico mais espinhoso que o mal. Deus deu liberdade ao homem e, portanto, podemos admitir que ele não é o responsável pelos crimes da humanidade. Mas a responsabilidade pela merda cabe inteiramente àquele que criou o homem, e somente a ele. (KUNDERA, 2008, p. 241)

Segue-se que o acordo categórico com o ser tem por ideal estético um mundo onde a merda é negada e onde cada um de nós se comporta como se ela não existisse. Esse ideal estético chama-se kitsch. (KUNDERA, 2008, p.243-destaque do autor).
}

Barroso aponta esse acordo representativo de uma estética que constrói "a ilusão de um mundo paradisíaco sem contradições, desacordos ou dúvidas. Especialmente a atitude kitsch procura criar esteticamente um mundo sem excrementos" (2013, p.73).

Em a Insustentável leveza do ser (2008), a ideia do kitsch explorada por Kundera nasce da evocação de Sabina, personagem do romance, que, enquanto indivíduo que omite seus sentimentos quanto ao ridículo em situação de prazer com seu amante Tomas, sofre pela percepção da busca e necessidade do superficial e esteticamente harmônico, representado pelo chapéu coco de seu avô. As lembrança e nostalgia de um outro tempo conduzem à ação kitsch, que se opõe ao presente e ao "real".

O debate da objeção da merda enquanto ordem metafísica, proposta pelo escritor tcheco, imprime o kitsch como expressão sentimental de uma época.

o kitsch, em essência, é a negação absoluta da merda; tanto no sentido literal como no sentido figurado: o kitsch exclui de seu campo 
visual tudo o que a existência humana tem de essencialmente inaceitável. (KUNDERA, 2008, p.244)

O efeito contrário do kitsch na escrita literária é próximo à abjeção e obscenidade, já que consiste na exposição irrestrita de elementos do corpo, especialmente do baixo-ventre, em que o gesto estético se propõe como princípio da discussão desmedida entre questões do desvalor e "animalidade". Mattoso diz que seu

(...)grande tema sempre foi a merda, mas foi uma merda muito consciente, quer dizer, uma merda dentro de todo um contexto de você mexer, inclusive, com valores literários. Metaforicamente, eu estava falando que muita coisa que se por vê aí é uma merda, entende? (MATTOSO) ${ }^{72}$

O ideal estético pensado por Kundera e contextualizado por Broch é o resultado da ação manipuladora do efeito estético, de forma a buscar, não só aceitação, como um julgamento ético positivo, condutor da relação entre sujeito vs. objeto, mas, principalmente, como negação de todo e qualquer conflito gerado por questões da condição humana enquanto representadas pela arte.

Glauco Mattoso, já em suas primeiras publicações, principalmente a partir da defesa firme da escrita coprofágica, rompe com a busca pelo "bom" ou "prazeroso" efeito estético, recondicionando as necessidades do leitor/fruidor para um processo muito mais humano, e por isso, incômodo, de relação com a obra, em que a reflexão de questões da condição não podem ser ignoradas: cegueira, podolatria, masturbação, desejo pelo odor fétido do chulé, tortura, gozo... A transgressão do kitsch feita por Mattoso se dá a partir do momento em que ele traz à tona uma estética conduzida por temas inesperados, que são literalmente excluídos de alguma maneira nos mais diversos discursos, inclusive o literário.

A literatura, por carregar em si valores internos, não é passível de manipulação de efeito, a um primeiro entendimento. Contudo, ao se pensá-la como linguagem construída por uma estética, compreende-se que ela pode

\footnotetext{
72 Trecho de uma entrevista de Glauco Mattoso à Revista dos Bancários, disponível na tese de doutorado de Maria Aparecida H. da Silva, O des-curso Cínico, defendida em 2009. A entrevista estava disponível, anteriormente, no site pessoal de Mattoso, ligado ao provedor UOL, que retirou do ar em 2012, fazendo perder-se todo o conteúdo ali disponível.
} 
nascer do processo árduo de trabalho e conhecimento do escritor, que se propõe, muitas vezes, "dono" do que produz. O artista de objeto kitsch tem por trás da sua estética a intencionalidade, como forma de interferir na fruição do espectador e anular os efeitos da transformação. Quando se coloca o kitsch como uma estética manipuladora do efeito, o que está em jogo é a ideia da certeza de que essa escolha agradará o outro, sem que este queira questionar como ela foi escolhida, como foi criada e o quê, em sua essência, representa. O kitsch limita a capacidade interpretativa do homem, manipulando-o em seu processo de sujeito empírico, que deveria refletir ao experienciar a obra.

A arte, como expressão sensível humana, é capaz de ser livre, no contexto amplo da palavra, e representar, por alguma linguagem, uma estética produzida pelo criador da obra, seja ela visual, plástica, musical, etc.. Enquanto manifestação sensível da ideia, pensando no que propõe Hegel, ela, passa por um processo tanto sensível quanto racional para chegar em sua representação essencial, em sua gênese criadora. Como expressão, é também capaz de representar um indivíduo, uma cultura, uma religião e marcar determinantes que influenciam no conhecimento e, consequentemente, no julgamento a ser feito sobre tais aspectos.

Nesse raciocínio, é possível perceber que, nem sempre, a arte se propõe tão livre quanto parece ou representa, bem como não é, categoricamente, apenas uma expressão sensível do artista. A arte esbarra-se no kitsch e desconstrói a ideia de autonomia e de "arte pela arte", aproximando-se da intencionalidade do objeto e massificação da interpretação.

Colocado como manipulador do efeito, o que é kitsch torna-se algo externamente agradável e harmonioso, dentro de parâmetros préestabelecidos, livre de julgamentos inesperados e controversos, formulados previamente pela necessidade de anulação do conflito gerado pela arte, logo, destituindo o objeto de capacidade transformadora. No kitsch, pensa-se, durante a criação, em como resolver o problema da fruição e do gosto, pois, mesmo sendo considerado a "arte do mau gosto", ele não assume o mau gosto a priori. Só é de mau gosto quando alguém julga de mau gosto e esse alguém sabe (acredita saber) diferenciar o que é ou não kitsch. Pensando em caráter de consumo, quem compra o que é kitsch não tem noção de que aquilo o seja, 
pois adquiriu algo que, esteticamente é agradável, é belo e já aceito, ou seja, legitimado de alguma forma. Isso reduz 0 adjetivo kitsch à negatividade.

Mattoso não produz uma literatura de fácil consumo, mas transgressora e marginal-erudita, que exige do leitor uma atenção maior para que consiga compreender o processo criativo do artista, bem como as pujanças de significação, eliminando o julgamento a priori. Nele, a transgressão é a (re)construção e (re)significação do que foi destruído, jogado fora, esquecido. É a criação a partir de dejetos expressados pelo interdito.

A abjeção no contexto humano acaba por negligenciada e sua invisibilidade (não só imagética, mas de discurso) ameniza os efeitos por ela causados. Há, constantemente e naturalmente, a ação de ocultar o que está ligado aos excrementos do corpo, ao que, para o corpo, é destoante e inaceitável: o mau cheiro proveniente de partes íntimas, secreções, fezes, urina, os desejos sexuais e tudo o que indica imperfeição, como a deficiência física e mental ou a pobreza, por exemplo. Tudo isso não tem espaço de discussão e, mesmo dentro da arte, acaba, por vezes, jogado no terreno do cômico e jocoso, já que é desprezível e precisa ser amenizado no espaço em que cômico se faz capaz de eufemizar a abjeção.

Contraditoriamente, a "merda" é o que mais indica que o ser humano é humano. Portanto, negar a merda é negar o que é humano, e assumi-la é uma ação (ironicamente) desumana - mesmo sendo a mais humana possível. Por esta razão, Mattoso contraria a própria condição, pois nega o kitsch - que ameniza qualquer forma do trágico pela arte e desconsidera o conflito em busca de uma harmonia - e expõe aquilo que ninguém quer ver, ouvir, falar, refletir e, muito menos confessar.

Assumir o que é ocultado ou excluído é excluir-se, pois quem assim se posiciona, acaba por se enquadrar fora de um modelo já aceito, um modelo comum e confortável de fruição. A inserção de Mattoso no universo da escrita marginal se dá muito mais pela sua representação antikitsch do que pela ausência de reconhecimento e espaço no âmbito da literatura brasileira.

Quando ele escreveu seus manifestos no JD, quando se autoficcionalizou no Manual, posicionando-se contra um ideal estético, ele expôs de maneira crua e deliberada, tudo o que há de transgressor na linguagem, principalmente ao se utilizar de palavras incômodas, coloquiais, 
chulas, cuja carga semântica está completamente controlada por valores externos morais. Essa ação antikitsch, exercida por ele, contesta, por meio do que é natural e humano, dispensando o fantasioso e harmônico das palavras sejam elas formais, científicas ou poéticas. Mattoso assume aquilo que uma estética kitsch encobertaria, ou seja, a verdadeira "merda".

No Manual do podólatra amador, texto que se propõe, inclusive, como paródia de narrativas literárias de educação sentimental (FOSTER in MATTOSO, 2006, p.11), toda a baixeza relacionada às mais profundas estreitezas e necessidades do corpo é colocada de modo sistemático e discutível, valorizando o orgânico por improváveis (ou indizíveis) angústias do indivíduo enquanto animal. Mattoso afirma a "merda" crua e a promove como espaço mais propício para ser mostrar verdadeiramente humano.

Para quem trabalha com a arte da palavra, nada mais inquietante que colocar em paralelo a "merda" como representação de questões legítimas e discursos oníricos, fantasiosos e até ideológicos... ao passo que lhe permite a magnitude enquanto ação transformadora. A escolha por uma estética que descontrói o harmônico gerado pelo kitsch desestabiliza o papel das palavras, das ações e da arte, pois choca e incomoda. Joga para um único plano aquilo que é de estilo impecável e o que é excretado e execrado. Argumenta contra a própria ideia de humano, que falseia a si mesmo para efeito estético do outro.

\subsection{0 antikitsch diante de uma estética contemporânea}

O prazer dos sentidos, o jogo das formas, o retorno com força da natureza, a intrusão do fútil, tudo isso complexifica a sociedade, mas, mais que a uma abdicação do espírito, isso faz apelo a um conhecimento mais aberto, o que acabo de denominar razão sensível, conhecimento que não forçosamente fácil, e que exige do leitor um esforço que está à altura do desafio que lança a heterogeneização galopante de nossas sociedades.

Michel Maffesoli No fundo das aparências 
Até o momento, nosso olhar de leitura epistemológica da obra de Glauco Mattoso buscou nos elementos fundadores do pensamento estético uma forma de conhecer seu processo de criação enquanto competência e escolha. As questões dos elementos racionais promulgadores de uma estética glaucomattosiana só nos foram identificadas, porque assumimos regressar aos estetas clássicos como forma de compreensão fecunda de como a arte é ocupante do espaço do conhecimento. Nota-se que durante nosso discurso empreendido, em alguns momentos falamos da relação sujeito vs. objeto, numa perspectiva de compreensão do criador diante da obra, bem como do leitor/espectador diante da obra.

A significação do objeto de arte, do artista e do espectador (ou fruidor) da arte sofreram inúmeras transformações ao longo das eras. $E$ isso inclui o objeto livro. No medievo, com a estética e fruição dominadas pela Igreja, o espectador era invisível, pois os valores da obra já estavam intrínsecos àquilo proposto pelos grandes circuitos da arte: os espaços ocupados pelo cristianismo. Kant (2010), ao propor destituir o objeto de valor e conceito, inaugura o sujeito espectador, o sujeito dotado de juízo e gosto, fruto do processo sublime da relação entre sujeito e objeto. Mas a obra (ou o objeto) possui história. E esse espectador passará por essa história para melhor compreensão da obra e seu efeito estético, dirá Hegel em seus cursos de estética. Dessa feita, a modernidade começa a esboçar novas relações de interpretação e compreensão da arte que almeja dar conta dos efeitos por ela causados. Entretanto, o emblemático século XX reconfigura o conceito de objeto artístico, seja pelo advento da fotografia, seja pela propaganda e 0 engajamento na arte, seja pela cultura de massa. Como falar do objeto se ele não depende mais da unicidade ou da "aura", como dirá Benjamin (1994)?

O objeto artístico começa a se perder em meio ao processo conceitual da arte e à reprodutibilidade. Em meio aos conceitos, o espectador, para não só mais contemplar, mas também participar e interagir com a obra, se verá necessitado de elementos e códigos que the permitam uma imersão, bem como da intuição. Mas esses códigos nem sempre estão disponíveis, o que vai reformular a arte enquanto dado de criação massificada, de fácil acesso e 
consumo. Obviamente essas discussões não se encerram nas questões estéticas kantianas e hegelianas. Quando recortamos nosso olhar para a criação artística na literatura, o objeto em questão passa a ser ressignificado no contemporâneo, para dar conta das criações híbridas e dos discursos plurais da atualidade.

Glauco Mattoso é um escritor contemporâneo e junto ao seu tempo traça-nos um caminho a ser alcançado, que é o da relação de um sujeito antikitsch com as atualidades estéticas. Esse movimento presente traz um novo olhar diante do objeto artístico, pois o que prevalece não é mais o efeito estético oriundo da relação sujeito vs. objeto, mas das relações humanas e afetivas com o objeto, carregado de conceitos, sentimentos e histórias. A pluralidade das significações contemporâneas na arte configuram novas formas de relações, que não buscam mais o conhecimento por meio do estético, mas, sim, o efeito por ele causado.

Junto à modernidade, conforme vimos nas discussões sobre o kitsch, surgiu uma sociedade pouco preocupada com o sistema de criação e extremamente ligada às multiplicidades das expressões comunicacionais e os efeitos por elas causados. Dessa feita, a subjetividade, enquanto exclusividade do espírito do sujeito, começa, principalmente no século $X X$, a exigir espaço de representação individual e social, haja vista o advento de várias áreas do conhecimento, como a psicologia, a psicanálise e a sociologia.

Embora a noção de sujeito do século passado tenha se tornada essencial para a compreensão das relações humanas atuais, cujas influências foucaultianas direcionaram para um sujeito cultural e historicamente plural, é no século XXI que a ideia de indivíduo e identidade, pensada aqui pelo contexto de Maffesoli (2008), será evocada. Com a intenção de compreender os espaços ocupados pelo sujeito que cria, por sua obra e por aquele que a frui, tem-se no sociólogo discussões próximas das novas relações da arte com os espaços em que ela circula e seus, não mais fruidores, mas, sim, consumidores. Ampliando o conceito de sujeito, agora, fragmentado, a noção de indivíduo defendida por Maffesoli perpassa as questões coletivas e se destacam enquanto modus particular do sujeito que sente, deseja, cria, conhece e se reconhece subjetivamente. Ele dirá: 
assim que passa a ser a questão de intuição, assim que se passa a levar a sério o papel desta última progressão intelectual, não se pode economizar a subjetividade, que não é privilégio de um indivíduo isolado, mas pertence a uma pessoa que se situa numa vasta rede de inter-relações e que comunga em mitos comuns. (MAFFESOLI, 2008, p.142)

Dito isso, será na contemporaneidade que a criação artística dará conta das questões subjetivas, quando estas antagonizam, negam ou até mesmo excluem modelos e estilos. A busca por formas novas que deem conta dessa subjetividade é uma característica do sujeito contemporâneo.

O espaço ocupado pela literatura enquanto forma (estética), por exemplo, vem cada vez mais ampliando suas perspectivas e a ideia de cânone vai sendo trincada pelas imersões de textos marginais ou pluriartísticos, cujas características não se fundamentam num modelo de produção ou gênero. Também, o processo de conhecimento inter e transdisciplinar vai romper com as fronteiras racionais das áreas do conhecimento e promover novas formas de saberes, que darão conta dessa sociedade produtora de uma arte cada vez mais plural, principalmente quando reverberadas ou compreendidas pelas relações.

Maffesoli, em Homo Eroticus (2014), vai defender que esse indivíduo contemporâneo, multi-identitário, resgata aquilo que a racionalidade sufocou: a sensação. As percepções do sociólogo francês compreendem esse indivíduo ligado àquilo que ele chamará de tribos. Embora se busque pertencer a uma ou várias tribos ao mesmo tempo, não há uma anulação total dos desejos e prevalências daquele que quer se sentir representado. Por esta razão, Maffesoli falará em comunhões emocionais, em que não se pensa mais no sujeito unívoco nem em um objeto, mas em indivíduos de comunidades, que dependem das relações para se reconhecerem, logo, se manifestarem.

Enquanto indivíduos que se resolvem em pequenos grupos, seus desejos e pulsões renovam-se por uma harmonia, que se propõe coletiva, forçando-nos a concordar com sua desconsideração ao que irá chamar de "visão antropocêntrica" e unilateral, pois as novas mídias e a virtualidade não mais concentram esse enraizamento. Por esta razão, cada vez mais se compreende os efeitos culturais no comportamento e nas escolhas estéticas, 
pois é no processo contemporâneo e social de pertencimento que esse indivíduo se constrói autônomo. Essa autonomia será compreendida na obra glaucomattosiana a partir das suas relações com os meios.

Glauco Mattoso continua em atividade. Cego, sua limitação foi reduzida com o advento da informática e, principalmente, da internet. Com seu computador falante, desde a década de noventa aos dias atuais, possui um ritual de produção matinal diário, cujo onírico das suas noites são colocados diante da tela de seu PC. Mas ele não se restringe ao Office para dar conta da sua criação. O dinamismo da sua produção vai do blog aos vídeo-poesia (sonetos declamados pelo autor) gravados por seu companheiro e inseridos no YouTube. Ademais, Mattoso mantém um perfil no Facebook, plataforma de interação social absurdamente imagética, cujas visualidades dominam o campo da cognição. Paradoxalmente, é no universo midiático e visual que Mattoso se representa literariamente.

Parece estranho para uma sociedade que sempre exigiu padrões dar lugar ao sujeito que essa mesma sociedade exclui: o deficiente. Para Mattoso, não há uma complacência social diante daquele que é desprovido de alguma parte ou sentido. A negligência é fantasiada de inserção social por meio de algumas minguadas tecnologias, inacessíveis à grande maioria. Mas será essa mesma sociedade a promover um discurso que contemplará particularidades antes, sequer, pensadas fora de seu contexto excluído. O próprio Mattoso (2006), ao tratar do tema sadomasoquismo, defenderá que, nos anos 2000, encontra-se grupo para tudo: inclusive para podólatras confessos. Exemplo este que retrata bem as novas formas de inserção de discursos, gostos e particularidades que são do privado, mas que buscam representação no coletivo, seja por meio da arte ou somente pela busca do estético.

As percepções de Maffesoli são otimistas enquanto subjetividade e sensação inerentes ao processo de conhecimento e das relações humanas. Embora elas convivam paralelamente com o que há de mais fascista na contemporaneidade, esse fenômeno só é possível diante de uma comunhão social. Comunhão, esta, que tem como obrigação permitir discursos plurais.

$\mathrm{Na}$ arte, essas manifestações são cada vez mais híbridas e comportam uma mistura multimídia avassaladora. Dessa feita, a relação sujeito vs. objeto, tão crucial na defesa do gosto kantiano e no contexto histórico do sistema 
hegeliano começa a romper com o universo dialético da fruição, expandindo-se para a vivência, interação e diálogo, indissociando-se um do outro. Consequentemente, aquilo que antes era do puro efeito estético particular, nascerá das relações humanas, numa busca atual por formas que deem conta desses efeitos individuais, realizados em comunhão.

As categorias do Belo pensadas por Hegel ganham novos espaços no contemporâneo, ressignificando conceitos de feio, grotesco, satírico, etc. e permitindo a ampliação de circuitos artísticos carregados de novas formas sensíveis de se pensar o ser e o social. A essas características vão chamar, na arte, de Pós-Moderno, dirá Teixeira Coelho (2005), principalmente pelo rompimento com um estilo e miscigenação de vários estilos, ao mesmo tempo. Mais do que isso, é um rompimento com o sagrado do objeto artístico.

Glauco Mattoso, pode-se dizer, é um artista pós-moderno e há vários indícios para isso. A começar pela sua escrita, formal, obediente ao acordo anterior à 1945. Esse retorno a um estilo de escrita não mais adotado, produzido hoje como contrariedade à nova imposição ortográfica é uma negação, princípio forte do pós-moderno. É um resgate de uma forma passada (e ultrapassada), mas que vai se adequando, pela arte, no tempo presente. Mais do que isso, Mattoso transita por diversas possibilidades de criação, não só pelo clássico soneto corrompido pela linguagem chula, mas pelas "brincadeiras" heteronímicas e explorações das mídias como forma de dar vasão à sua criação ficcional, que se propõe plural. A quebra de autoria também desmonta um lugar sagrado da criação artística: o criador. Ainda na década de 1970, o escritor já era vanguarda desse movimento das redes sociais, em que as informações não são legítimas.

Mattoso não é um escritor de um gênero, não é um artista de uma obra. Também não é um sujeito isolado do seu tempo. Mesmo em desarmonia, mesmo pela contrariedade de diversos de seus discursos atuais, como os artigos no Ephemerdas ${ }^{73}$, o escritor se faz presente. Por ser plural e versátil, Mattoso é um sujeito em trânsito, cuja obra mantém-se firma na contrariedade cultural.

\footnotetext{
${ }^{73}$ Disponível em:

http://www.blocosonline.com.br/literatura/prosa/colunistas/glauco/gm14emdiante/onomastindex. php
} 
É preciso encerrar, já indica o título. Mas o encerramento é também retorno, é voltar ao ponto inicial que conduziu nossa feitura. Optar pelo espaço conclusivo como oportunidade de depoimento significa, aqui, assumir esse retorno, sustentado pela pergunta incitada ainda na introdução: Glauco Mattoso como um antikitsch é uma possibilidade de (re)criar a si mesmo a partir da literatura, como denúncia da negação do humano existente dentro e fora do espaço literário?

A escrita afirmativa de um desalento encontrado nas dores da tortura convertida em prazer; a ojeriza promovida nas narrações do desejo pelo desagradável; a busca do gozo pela dor; o autoescárnio... todas essas ações (e sensações) são desdobradas na escrita de Glauco Mattoso como naturais e instintivas, por serem denúncias da condição humana. A desvelação da merda, conduzida pelos discursos adotados na escrita literária, transforma Mattoso num sujeito manipulador da palavra, que repensa sua existência e as condições dela como fragmentos formadores de um conjunto maior: a ficcionalização e estetização de si.

Nas três partes sustentadoras do eixo epistemológico desta análise, buscamos, pelo olhar da epistemologia do romance, construir um caminho para a compreensão da construção estética desse eu-literário criado pela pessoaescritor. Embora o corpus literário de análise fosse o Manual do podólatra amador, visitar outros textos de Mattoso contribuiu para alcançar os anseios acerca do contexto de criação do sujeito artista. Dito isso, o que justifica o autor como um autoficcionalizador, dependente de um heterônimo, não nasce com as tessituras dessa análise teórica, mas estão entranhadas em seus textos confessionais, insistentes nos poemas e narrativas em primeira pessoa.

Falar do "não-dito" e escancarar o incômodo e abjeto tema ligado às questões do baixo-ventre exigem do criador espaço de discurso. Discurso que ganha força enquanto transgressão na arte. A literatura de Mattoso assume 
esses princípios e fomenta uma construção baseada nas linhas da antiestética, contrariando os eufemismos da arte literária.

As evidências da intencionalidade nas obras de Glauco Mattoso são perceptíveis, principalmente enquanto objeto de análise. O observar analítico de uma escrita sadomasoquista e autoescarnecedora depara-se com a necessidade da reconstrução estética do sujeito enquanto ser criativo no mundo. E criação é contexto, é memória, é inovação e necessidade. Transitar pelo universo criativo do escritor é buscar vestígios da criação que são deixados nas trilhas da escritura. Quando encontrados, esses vestígios esbarram em nossos relicários memorialísticos.

Assumindo agora as particularidades da primeira pessoa, sinto-me autorizada a expor que a escrita glaucomattosiana, enquanto real e literária, sobretudo, autobiográfica, transporta a mim, leitora, aos espaços mais obscuros da relação sensível entre texto, pessoalidade e condição. Tenho isso como fórmula para dar conta das leituras e das minhas sensações diante dos textos do autor. Mas nesse tipo de fórmula não há uma eficácia. Há lacunas. Há emergências. Há retornos. O que, então, pode ser construído como palavras finais diante de um estudo de evidente envergadura? Caberia retornar aos extensos teóricos e justificar cada afirmação posta diante da pergunta maior? Creio que não. O movimento provocado pela escrita de uma tese é volátil. E, embora complexo e pesado, é paradoxalmente leve, sustentado, senão, pela razão sensível daquele que assumiu a pesquisa.

Por isso retorno com nuanças fixadas pelo processo de leitura. Elas que, como um feixe de luz, invadiram meus olhos, mediadas pela escrita de um cego. Como emergências, as leituras dos textos de Mattoso exigiam-me retornar a mim mesma. Já emaranhada em seu discurso de dor, em que o autor-narrador-personagem expurga tudo o que sente enquanto cria e tudo o que cria enquanto sente, coloco-me em cena.

Mattoso é um escritor de memórias: pessoais, literárias, coletivas, íntimas e engendradas. Das suas memórias, reencontro as minhas, e, aos poucos, enquanto afogada nas fortes leituras glaucomattosianas, deparo-me com o meu 'eu' envolvido em seu discurso de dor, de um autor-narradorpersonagem que sente aquilo que lê; que sente aquilo que cria; que sente aquilo vivencia. 
Desse complexo jogo de leitor $\mathrm{X}$ obra/autor/escritor, retorno agora, não à pergunta formal desta tese, mas à pergunta a qual sempre me deparo: o que me faz estudar Glauco Mattoso? Desdobrar esse elo aqui é justificar o movimento de retorno. É voltar ao início de tudo, como justificativa maior da infinitude de um encerramento.

Em 2007, lembro-me bem, estava eu, transitando por uma livraria do shopping, procurando alguma leitura (que coubesse no meu parco orçamento), um membro novo para minha mochila e minha estante. Passando pela sessão de jornalismo (?), lá estava: JORNAL DOBRABIL. Livro grande, diferente, capa intrigante. Era caro. Abri. Deparei-me com uma coisa sensacional, meio cômica, híbrida, poesia visual com palavrão. Fiquei vermelha. Não me era uma leitura comum. Apaixonada por Clarice e Manuel Bandeira, o ápice da transgressão literária que já havia lido era o conto "O cobrador", do Rubem Fonseca, lá por 2004, quando ainda cursava letras. Comprei o JD. la pra faculdade com ele. Nessa época, era aluna do curso de artes plásticas. Os colegas gostavam. Riam. Não conseguiam ler em voz alta e, repetidamente, me perguntavam: por que você está lendo isso? Acho que o tinham como um livro de piadas. E eu me sentia muito bem o portando.

Mais do que uma linguagem poética inusitada - para meu contexto reduzido de leitora comum dos livros da moda literária -, o que me intrigou, naquela época, foi a ousadia dele para falar daquilo que eu jamais falaria. Glauco Mattoso era um 'eu' que todo mundo queria ter: um eu de coragem.

Mas ainda não foi esse meu elo com suas obras. Mattoso me fez ver o quanto a condição humana é negada e sofremos por isso. O bullying, narrado por ele com um sarcasmo doído pelas perseguições vividas me faziam lembrar do meu tempo de colégio: no meu caso, a condição pela qual eu era excluída e motivo de chacota era psoríase alastrada por todo o corpo. "Isso pega? Minha mãe não me deixa brincar com você!". Ah! o corpo... o desejo do corpo, a condição do corpo. Falar do corpo, para mim, sempre foi um tabu. Enquanto portadora de doença de pele, aprendi a escondê-lo; enquanto criança católica, aprendi a negá-lo; enquanto mulher gorda, aprendi a odiá-lo; enquanto mãe, aprendi a lamentá-lo; aprendi a ter vergonha por não ser aquilo que todos dizem ou querem ser. O corpo. Mattoso fala do corpo, fala das partes do corpo, entrega-se ao seu próprio corpo e àquilo que esse corpo quer sem nenhuma 
dificuldade. Ele ri de seu corpo. Seu corpo falho, seu corpo ausente de um sentido, seu corpo envelhecido. Essa coragem que ele suporta me é invejável. E vendo tanta expressão nas palavras daquele corpo que comporta seus pensamentos e criação, veio-me um diálogo imediato: meus desenhos.

Se o corpo era um problema para mim, a arte, mais ainda. Sempre fui encantada pelos efeitos que arte me causava, da música à pintura, dança, escultura... mas tudo me era limitado. Reduzida à compreensão de poucas manifestações, era assim que eu pensava a arte: dentro de pequenos modelos sacralizados pelos meios. Só assim. E nela eu não me encaixava. Achei que a faculdade de artes fosse resolver meu problema. Piorou. O curso me trancafiou num buraco escuro, anulador da criatividade e pesado da crítica.

Desenhos? Meus desenhos? Isso é arte? De novo a negação de algo que era meu, que era de minha autoria, eu negava. E de novo. E de novo. Ocultava aquilo que sempre chamei de rabiscos para que ninguém pudesse dizer (pela milésima vez): "por que você não se dedica e se torna uma artista, um dia?" Um dia... Um dia...

O distanciamento da arte com aquilo que eu produzia era notório. Mas não era só uma questão pessoal. Era e é social. O que nosso corpo é para nós? O que produzimos? O que criamos? Por que criam por nós? Por que criam nossos corpos? Onde estão nossos corpos? Gosto de comparar arte e corpo. Ambos estão expostos: nas vitrines ou galerias; nos modelos ou nos grandes artistas; nos discursos. Mas não estão conosco. Não nos pertencem. A quem pertencem então?

E nas leituras de Mattoso, comecei a notar que toda a minha negação construída no discurso do corpo, na arte e no espelho, estava vívida no meu trabalho. Era ali que eu podia me expressar. O autoescárnio literário de Mattoso se materializava de forma semelhante no meu traço. Era ali que eu podia dizer o quanto é odioso esse universo usurpador dos nossos corpos e da nossa arte. A temática do corpo destorcido, feio, disforme, sempre esteve presente em meus rabiscos. Gosto disso. Gosto dos defeitos. Gosto de criar defeitos. Gosto de corpos misturados ou fragmentados. Não me importava mais se eram desenhados em saco de pão com 'cotoco' de lápis ou num papel de gramatura maior, com textura, à nanquim. Não mais me importava o que 
queriam do meu traço. O que me importava era como eu me sentia livre ali, numa simples folha de papel.

Posso dizer, depois de alguns anos como leitora de Glauco Mattoso, que sua arte me transformou. Não quero professar um discurso religioso, de salvação. Seria até patético da minha parte. Não. Quero apenas expressar que compreender pela arte aquilo que é real permite transformação. Não sou mais a mesma. Meus discursos não são mais os mesmos. Minha arte não é mais a mesma. E por influência maldita do escritor maldito, meus rabiscos me acompanharam e se tornaram extensão das minhas leituras. Uma necessidade ardente.

É isso.

E já que estamos aqui, reservo este momento conclusivo (?) para apresentar a você, leitor, meus desenhos frutos das leituras dos textos de Glauco Mattoso. 
|| Galeria

A seguir, desenhos feitos em diálogo com leituras da obra de Glauco Mattoso. Alguns só existem em arquivo digitalizado: uns foram danificados, outros não estão mais comigo, porque foram dados a amigos, com muito carinho. Os desenhos que estão no corpo do texto e na capa não estarão expostos adiante. 


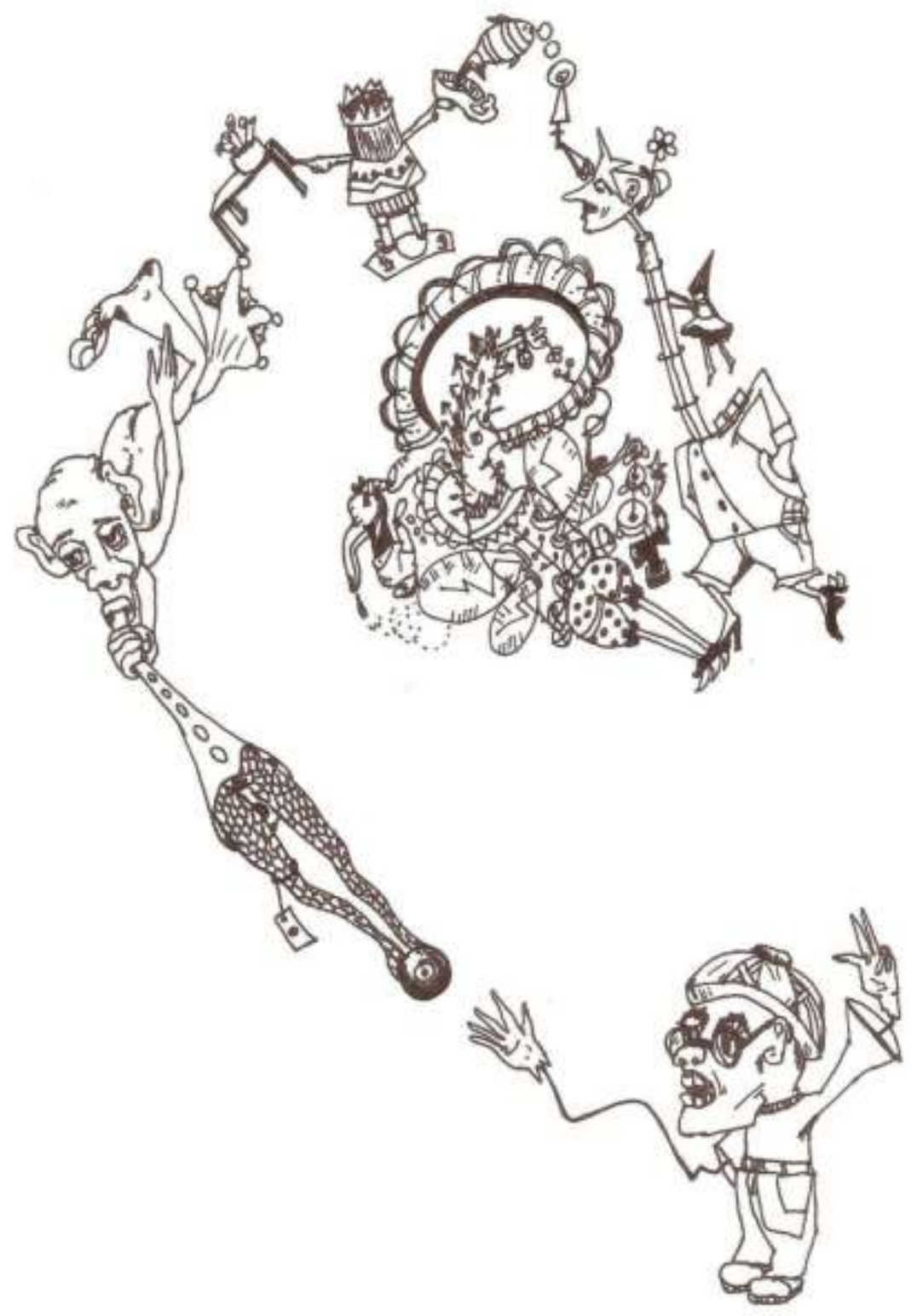

Espiral sonetário, 2010. Caneta sobre papel. 


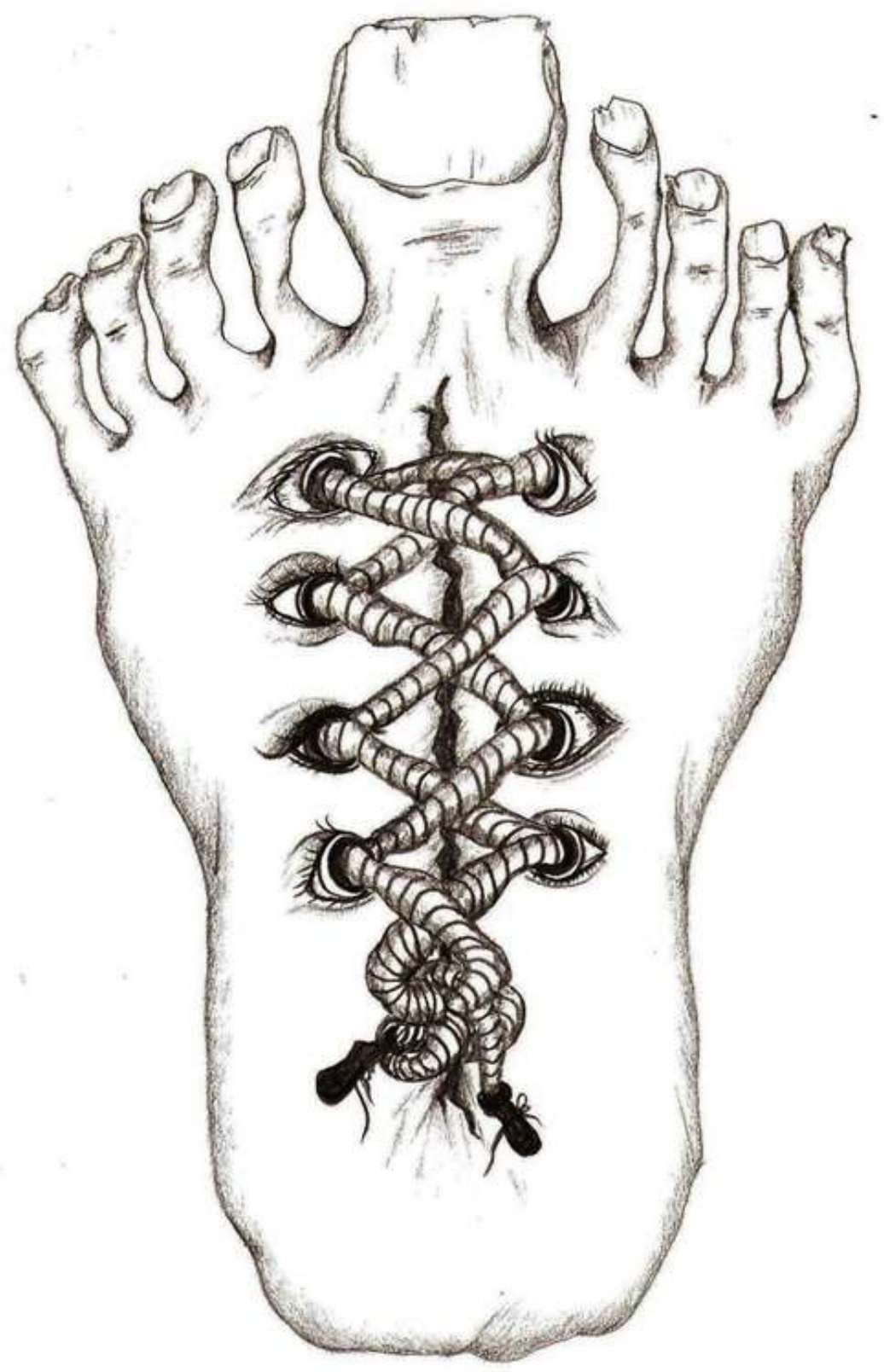

O pé sujo, 2012. Lápis sobre papel A4. 

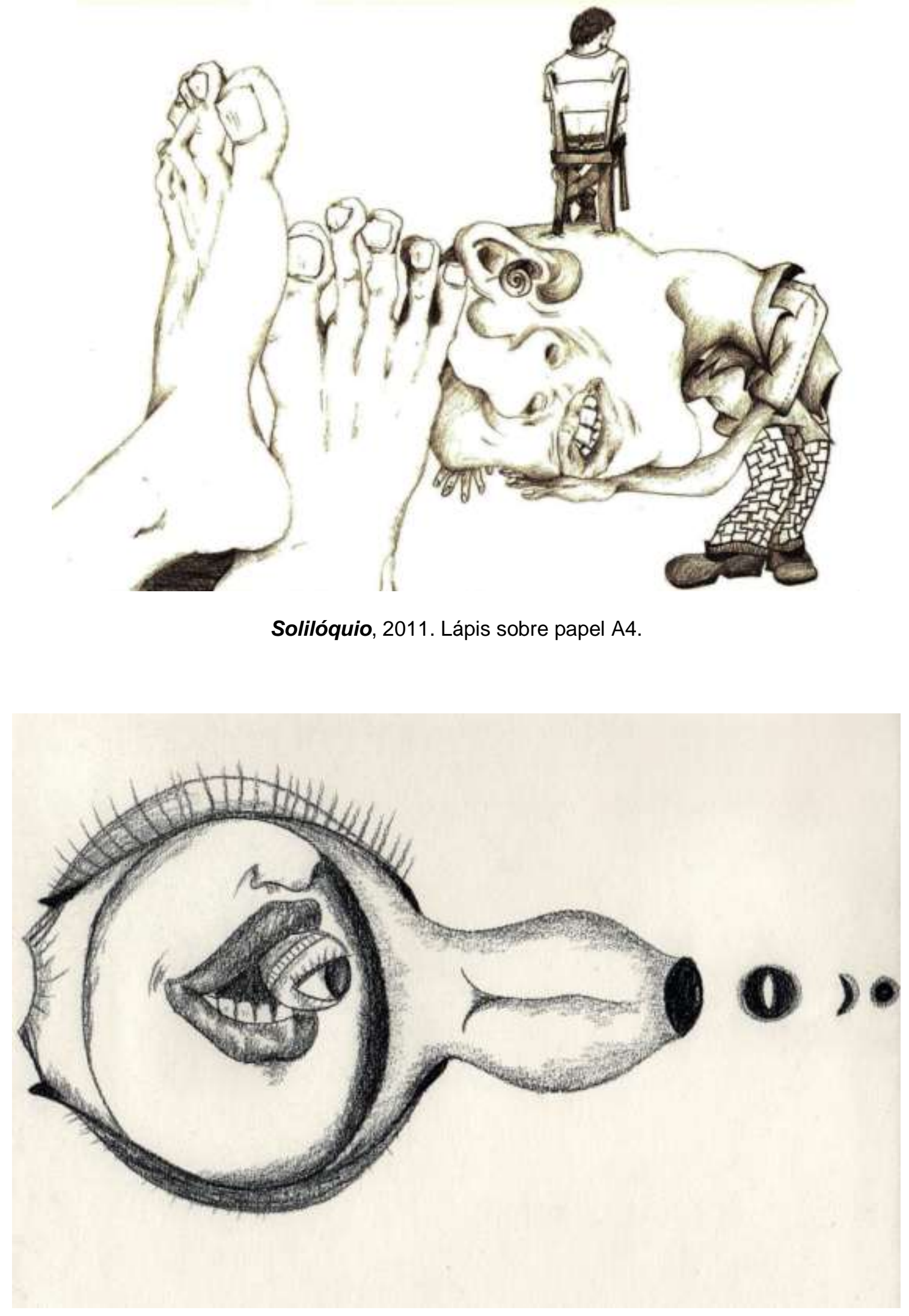

Glaucoma, 2013. Lápis carvão sobre papel. 


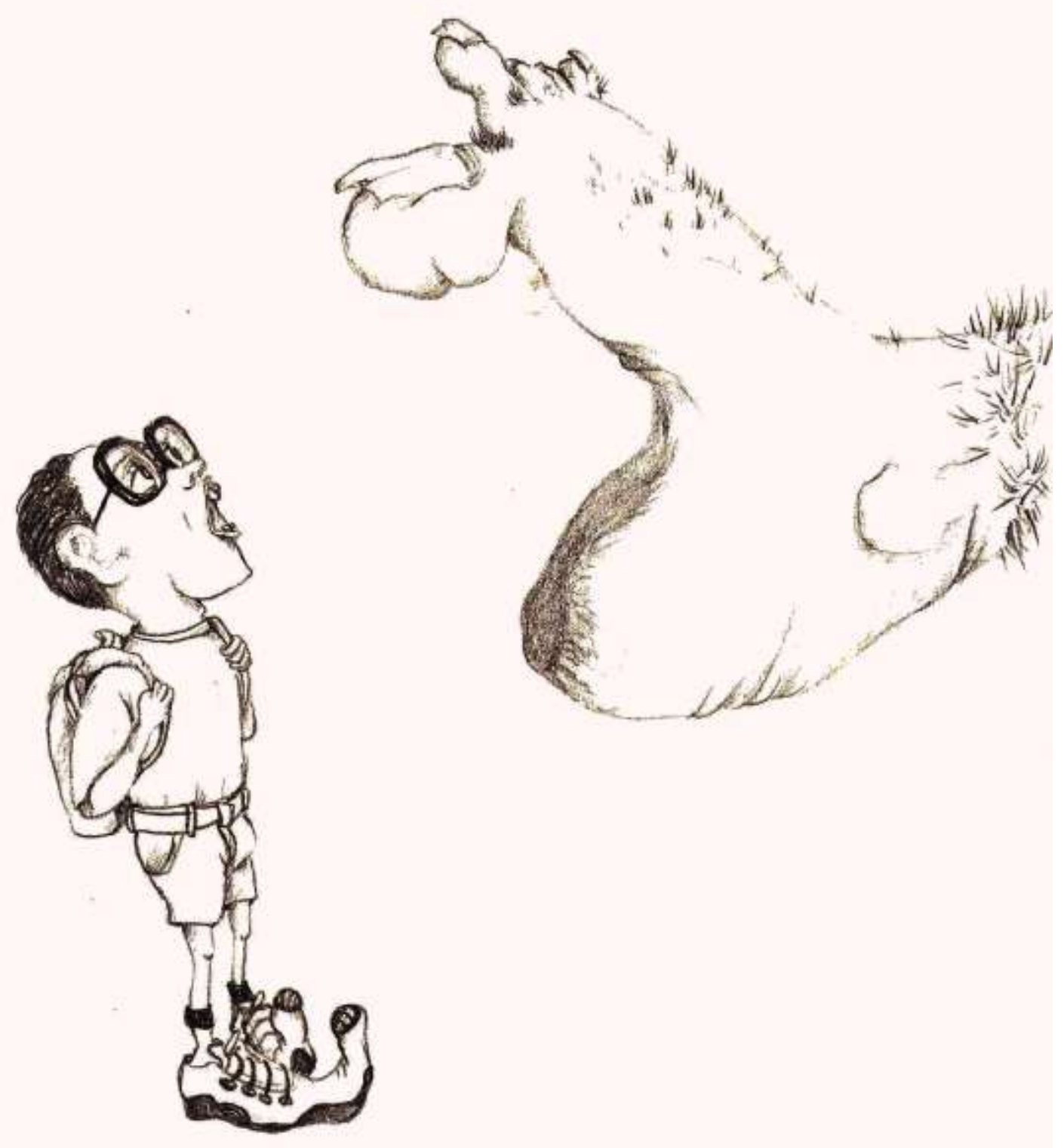

Glauquinho, 2011. Lápis sobre papel. 

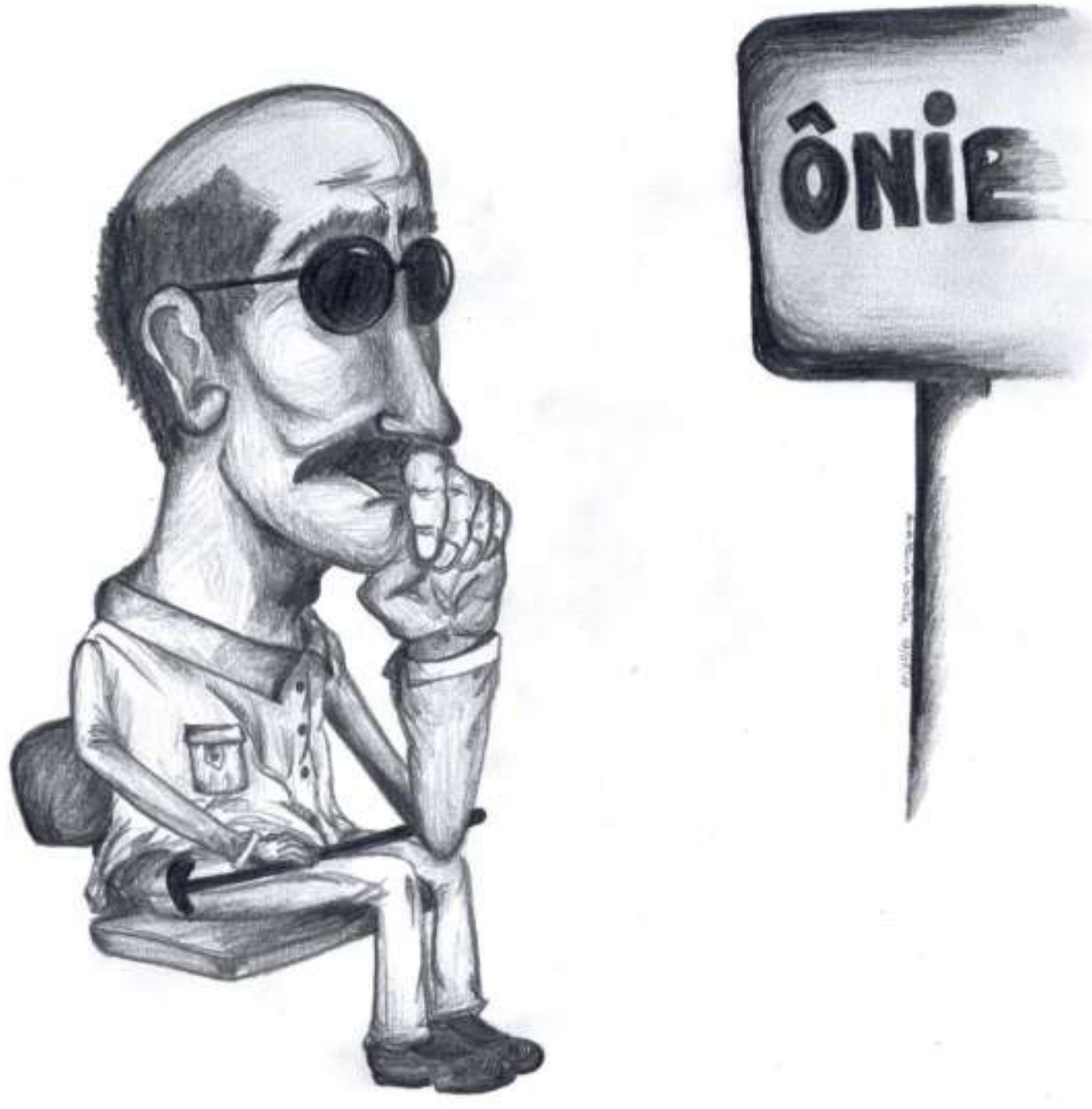

Um cego qualquer, 2008. Lápis sobre papel. 

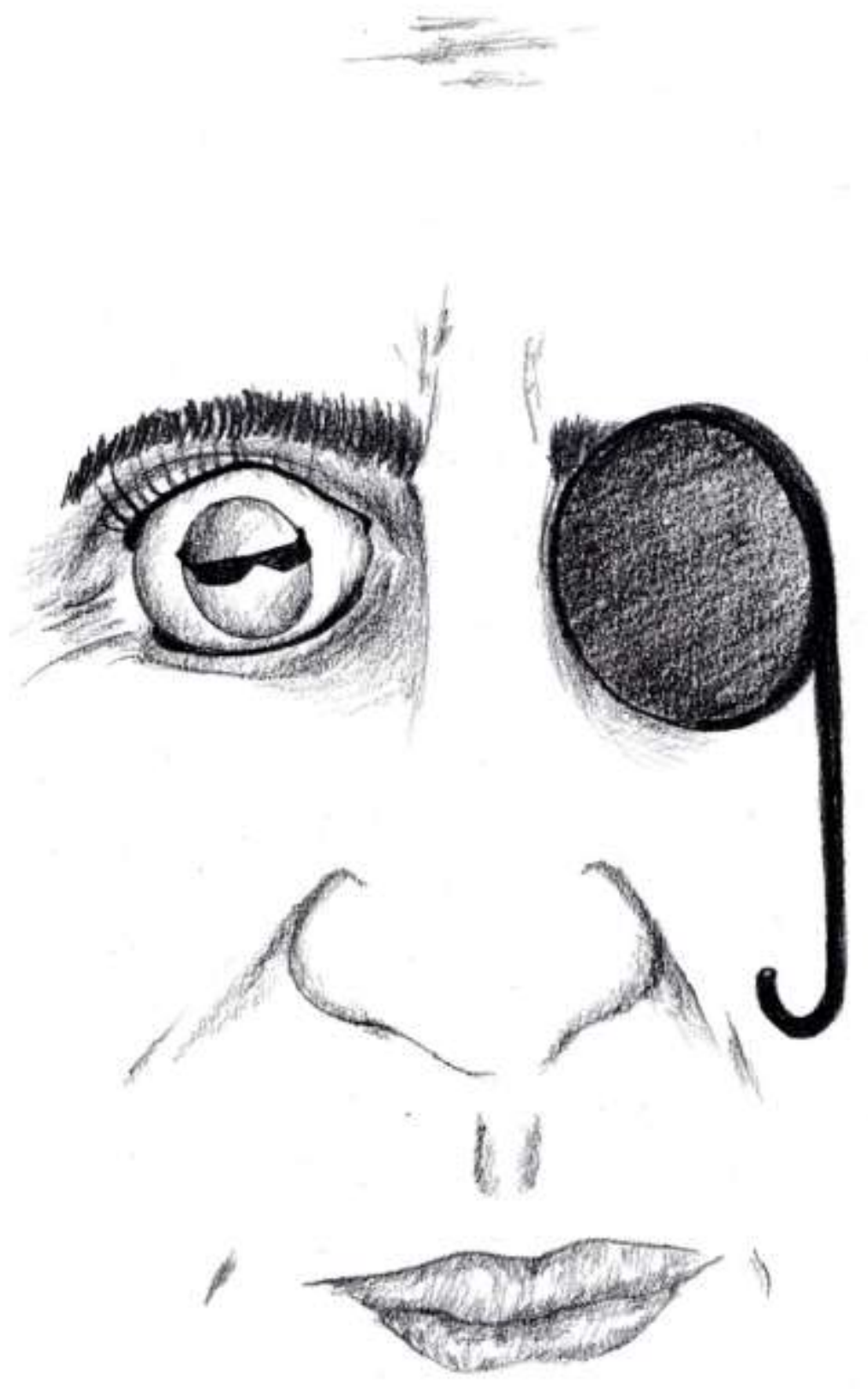

Monóculo, 2014. Lápis sobre papel. 


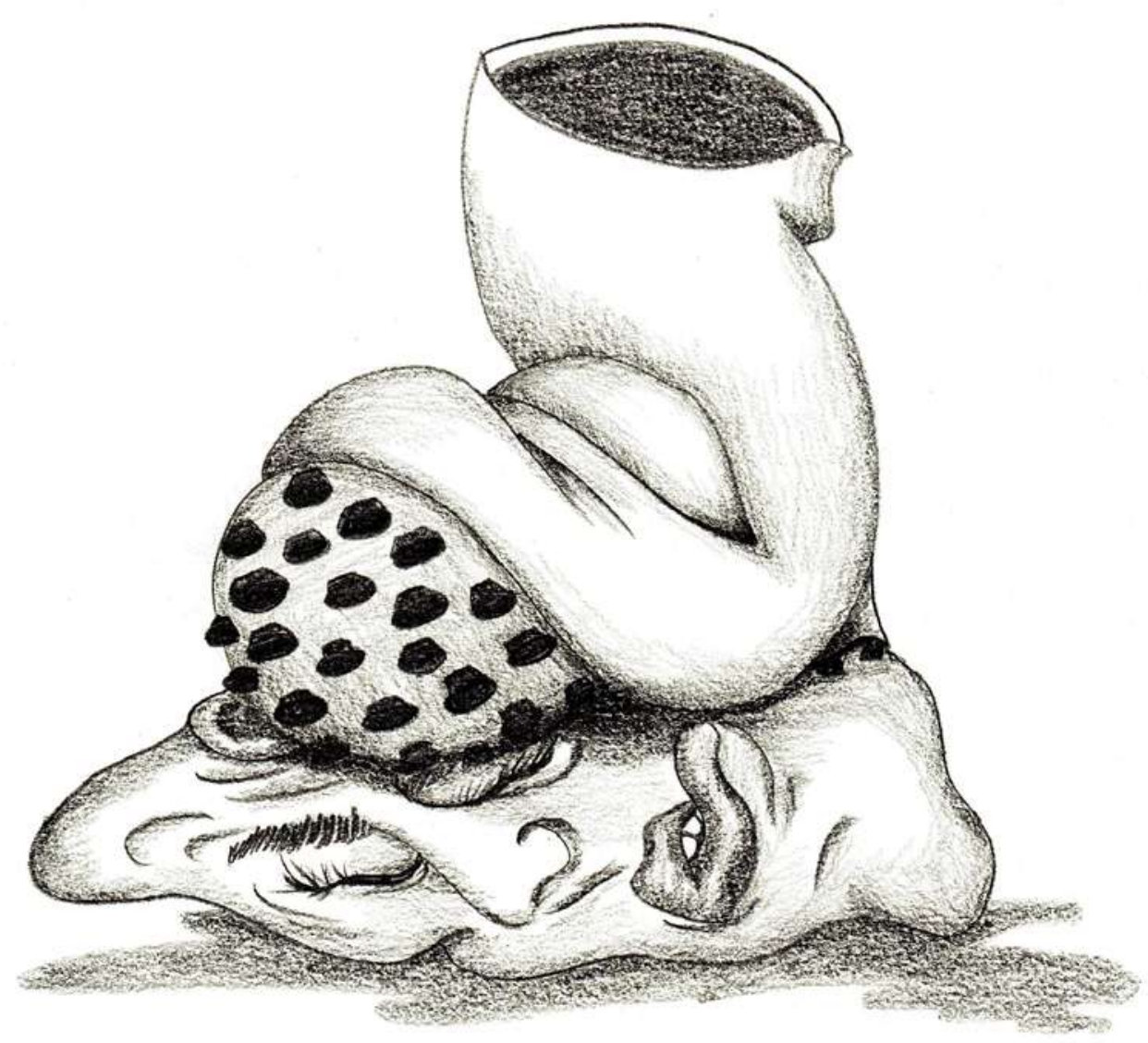

Botina, 2014. Lápis sobre papel. 

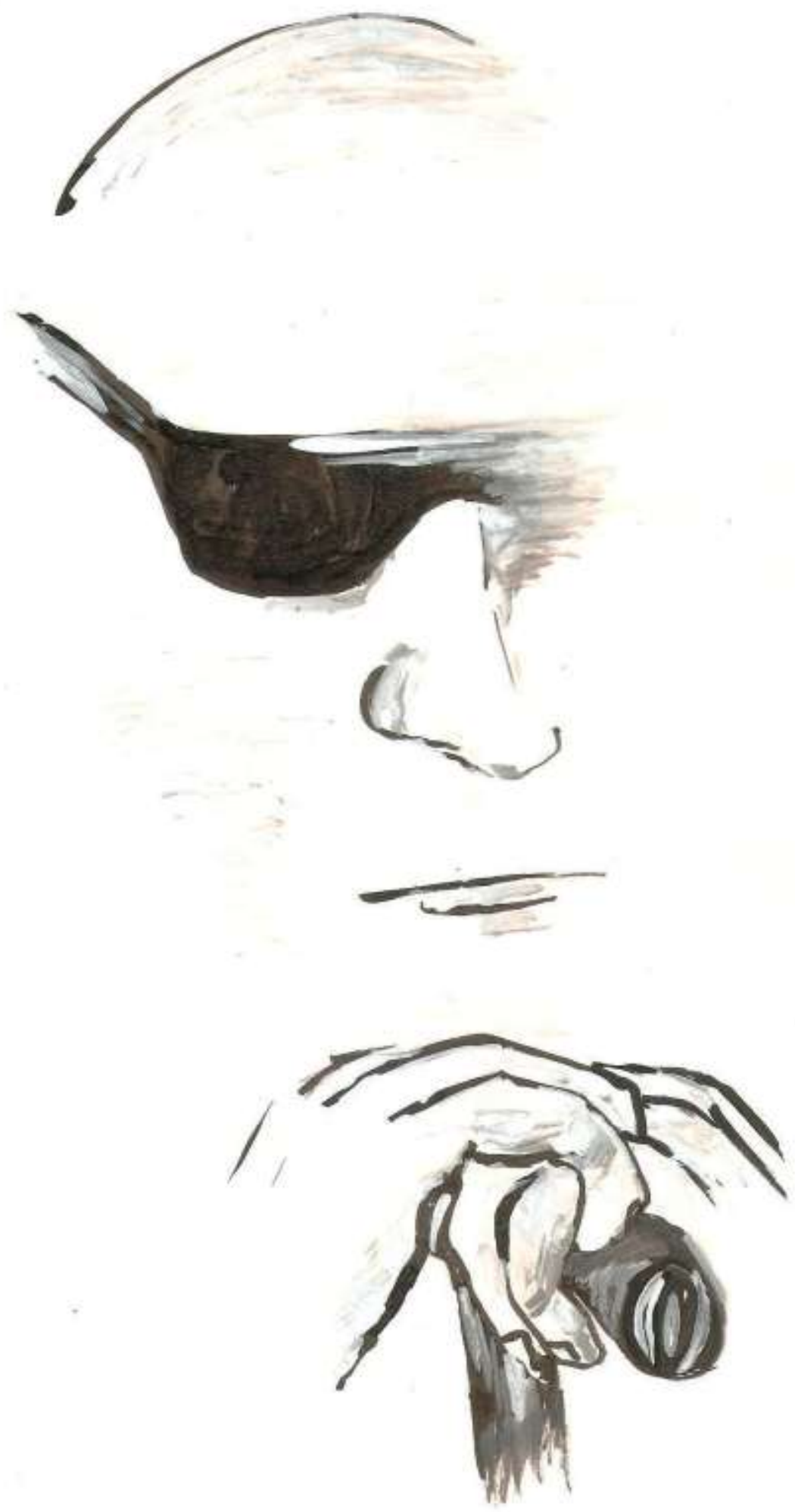

GM, 2013. Nanquim sobre papel. 


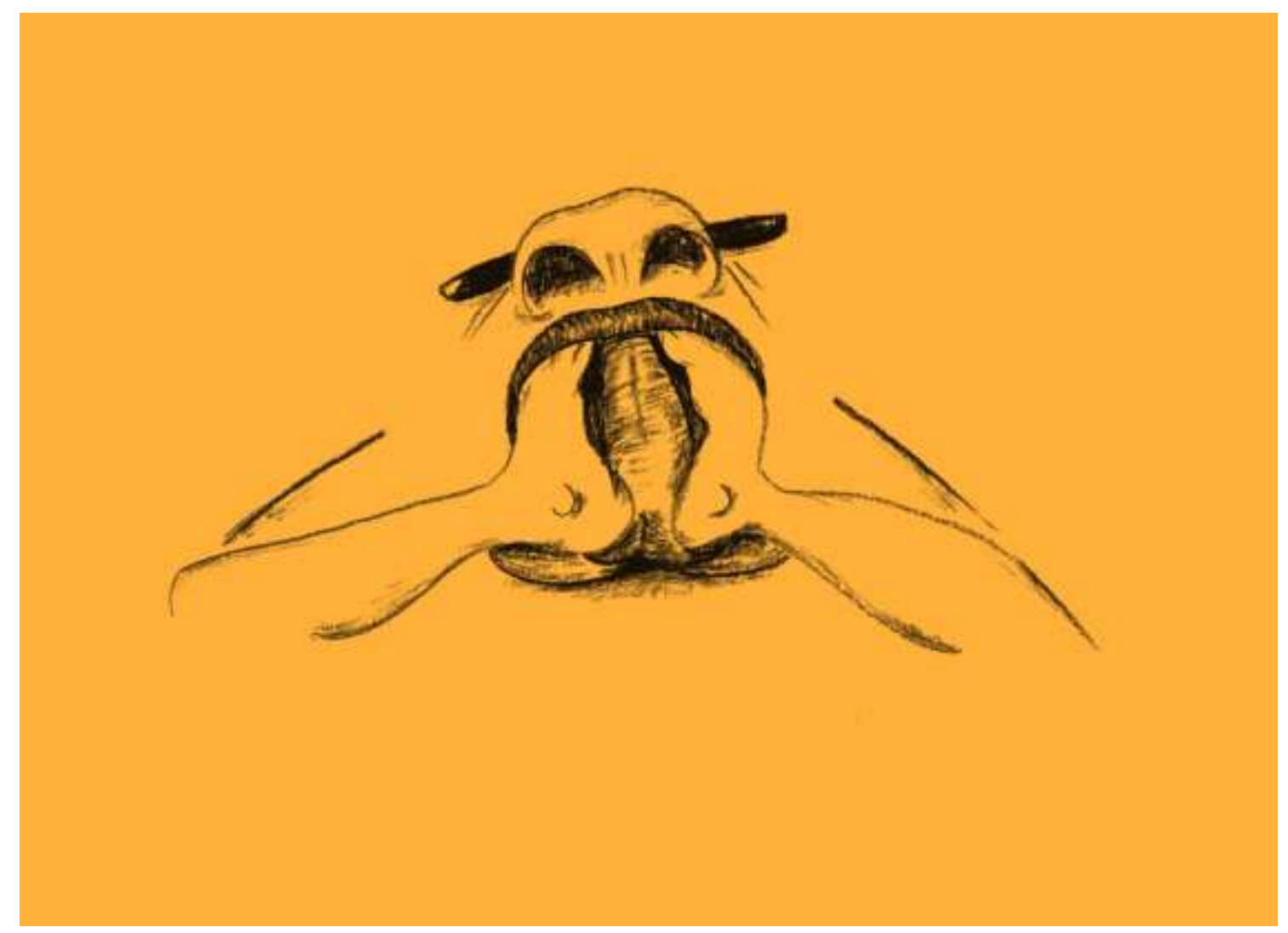

Antropofagia, 2014. Lápis carvão sobre papel colorido.

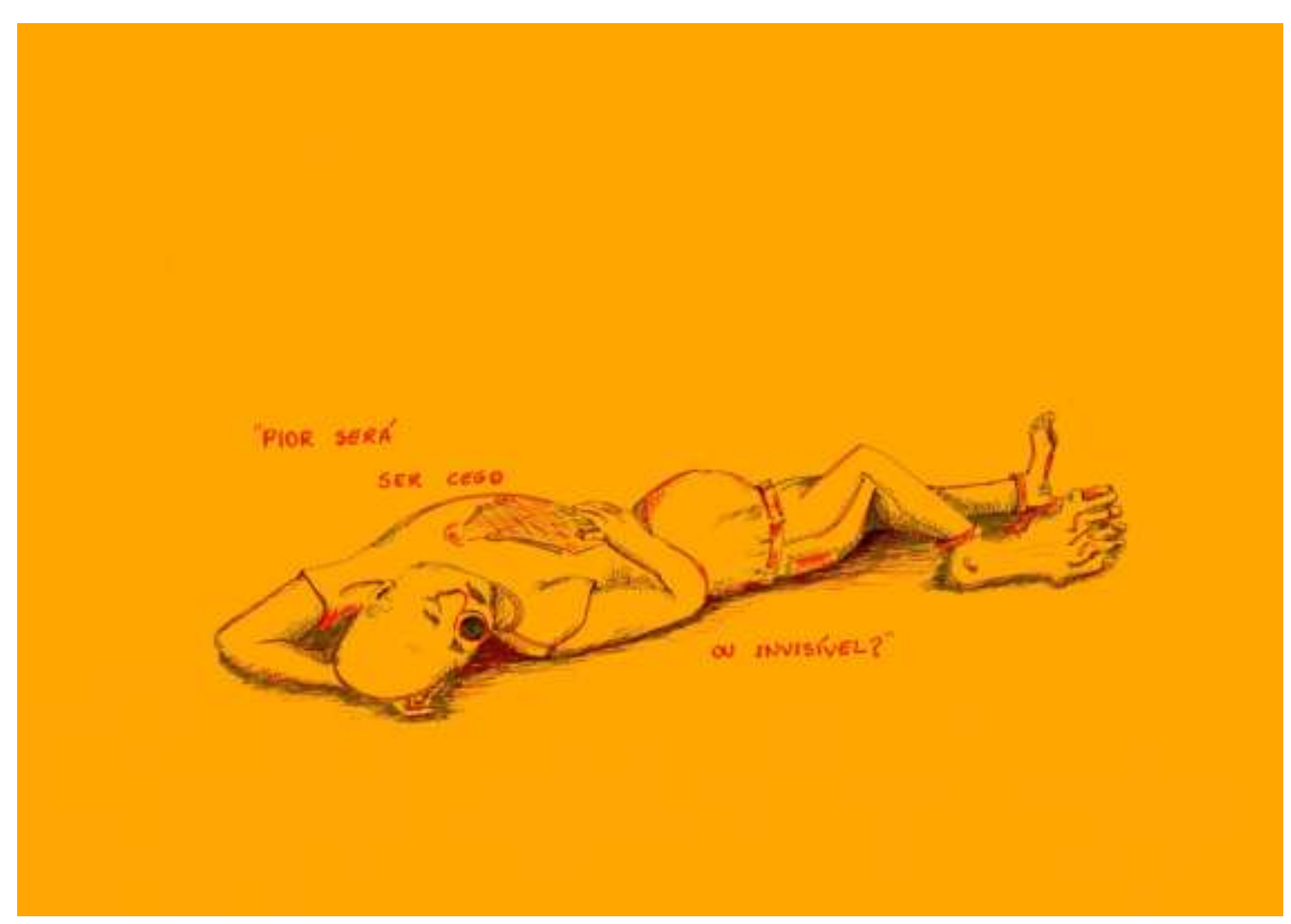

Alucinação, 2014. Caneta sobre papel colorido. 


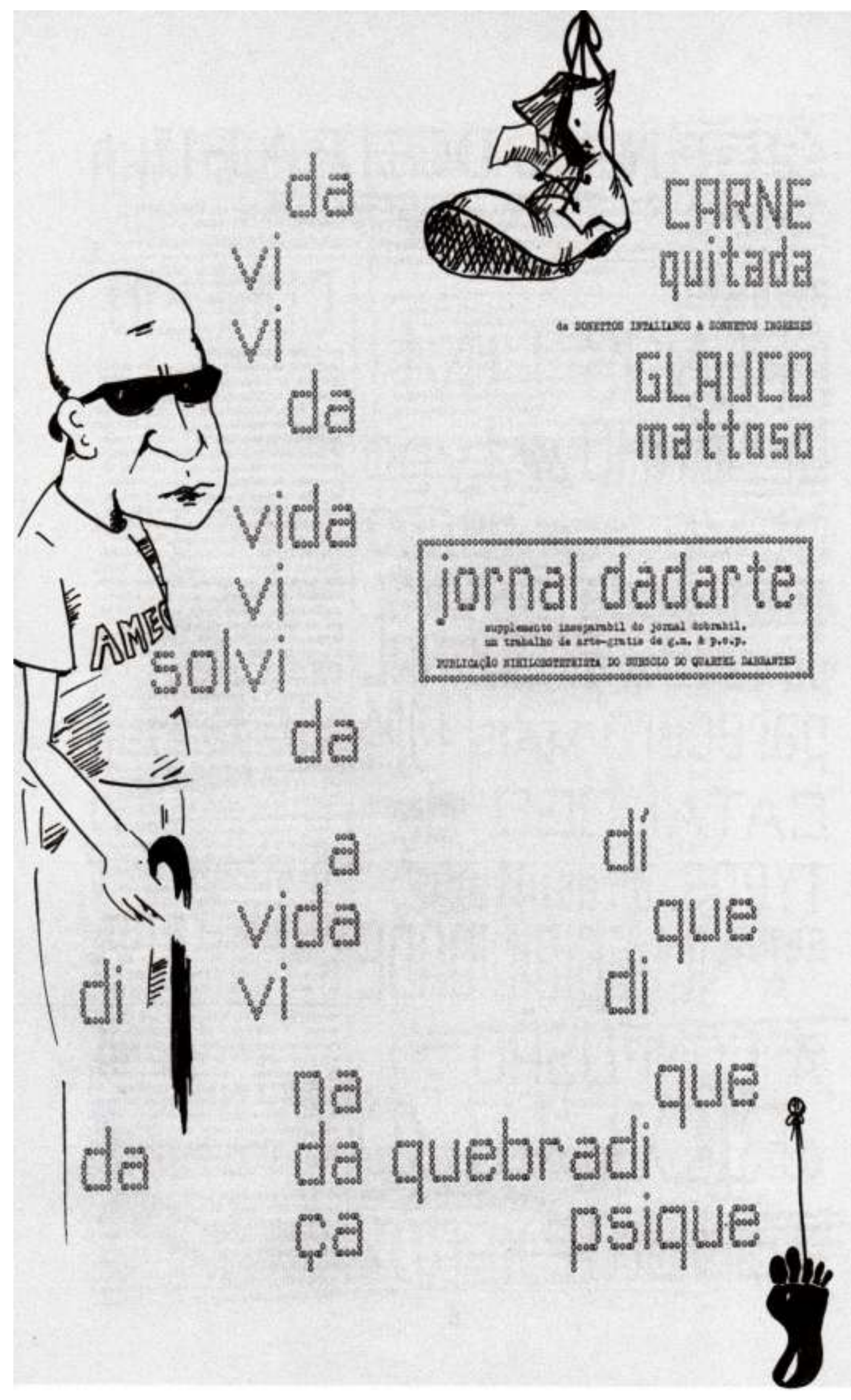

Mattoso sobre poema de Mattoso, 2014. Caneta sobre cópia de página do JD. 


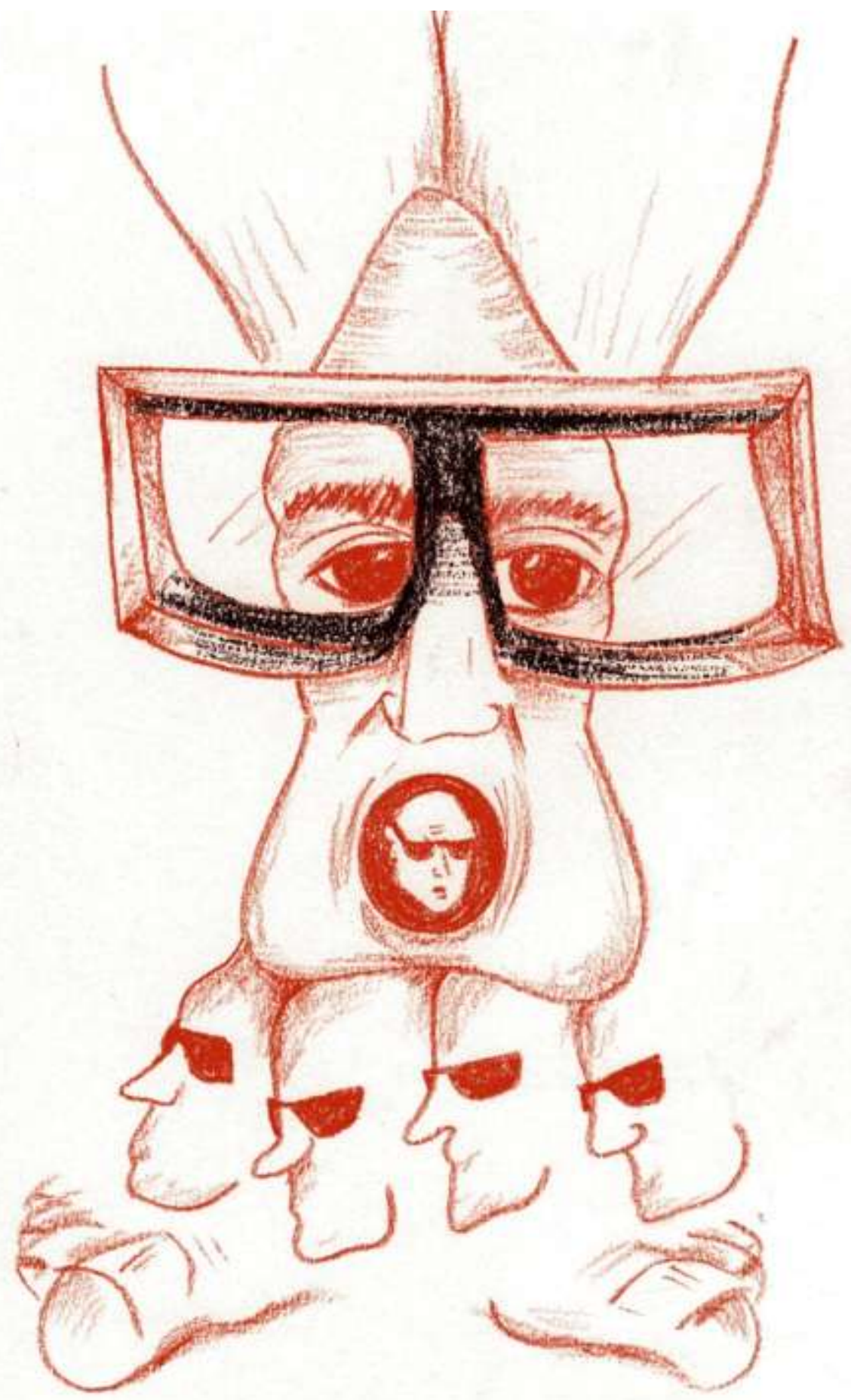

Heteronímia, 2013. Sépia e carvão sobre papel. 


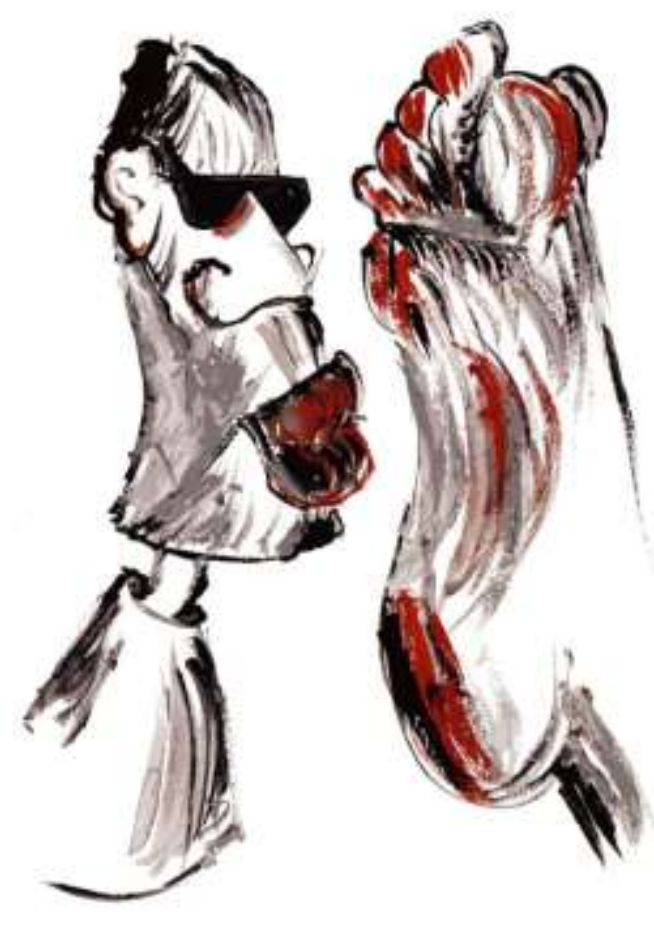

Fetiche, 2014. Acrílica sobre papel. 


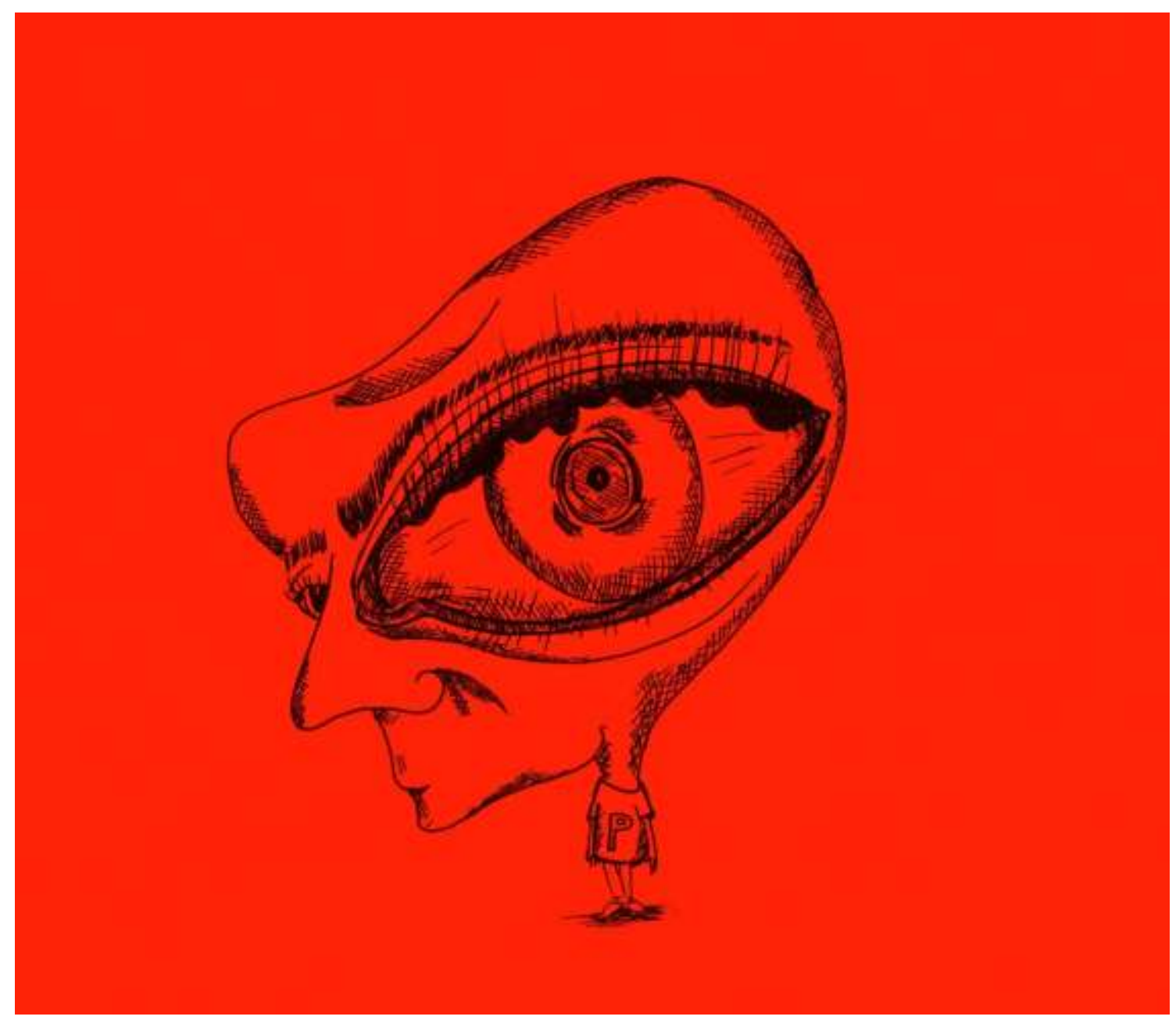

Olho impudico, 2014. Caneta sobre papel. 


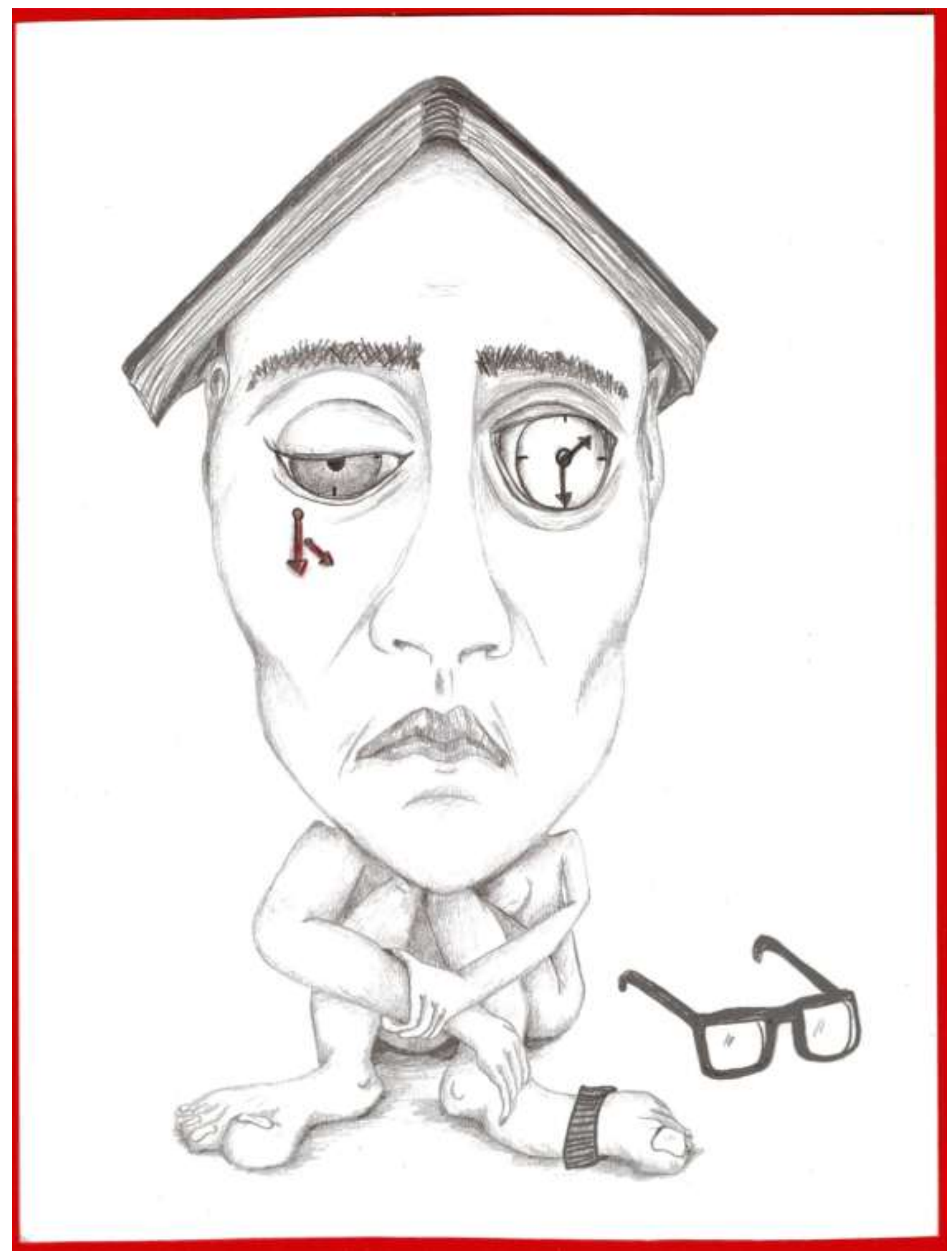

Iminência da cegueira, 2013. Lápis sobre papel. 


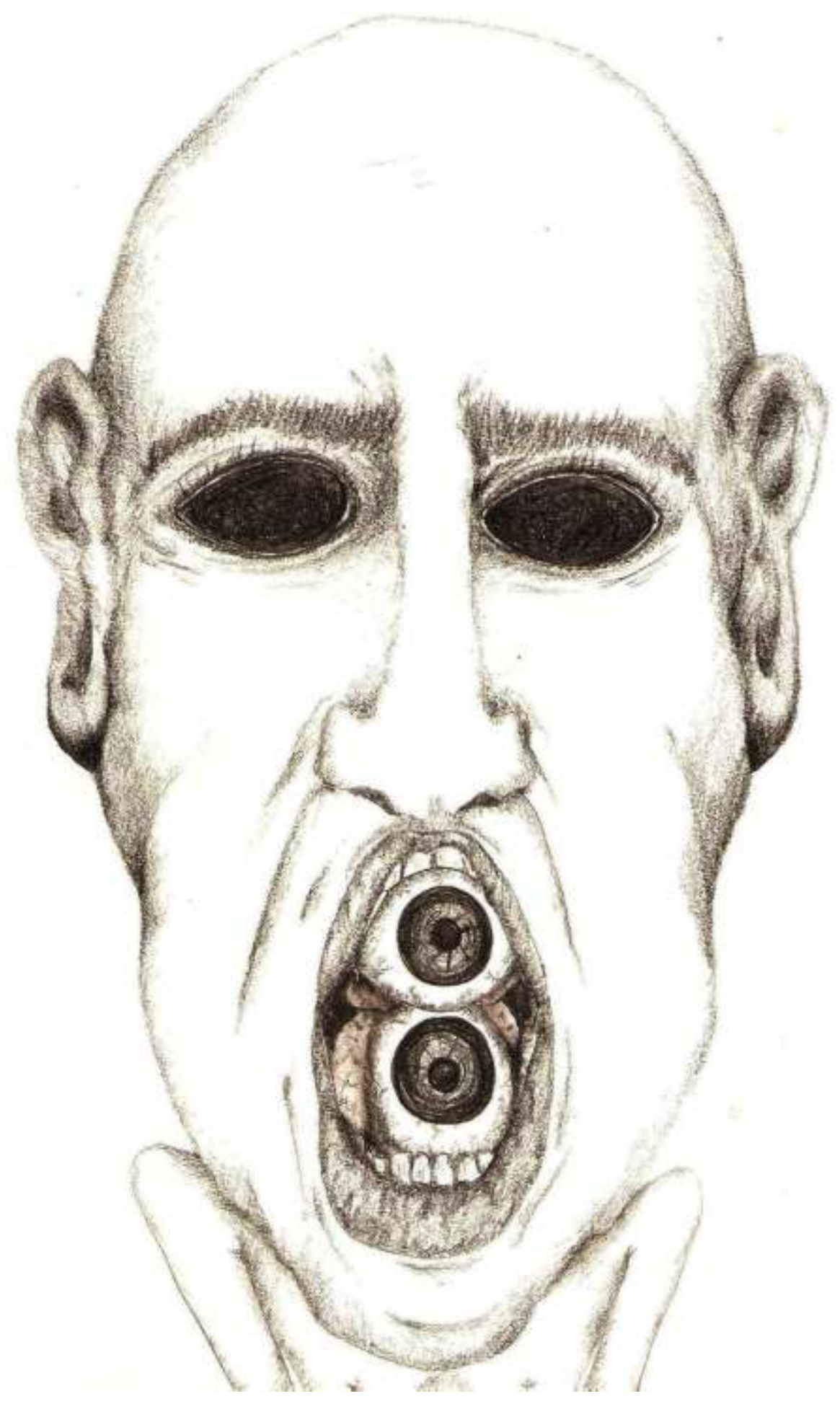

O glaucomatoso, 2011. Lápis sobre papel. 


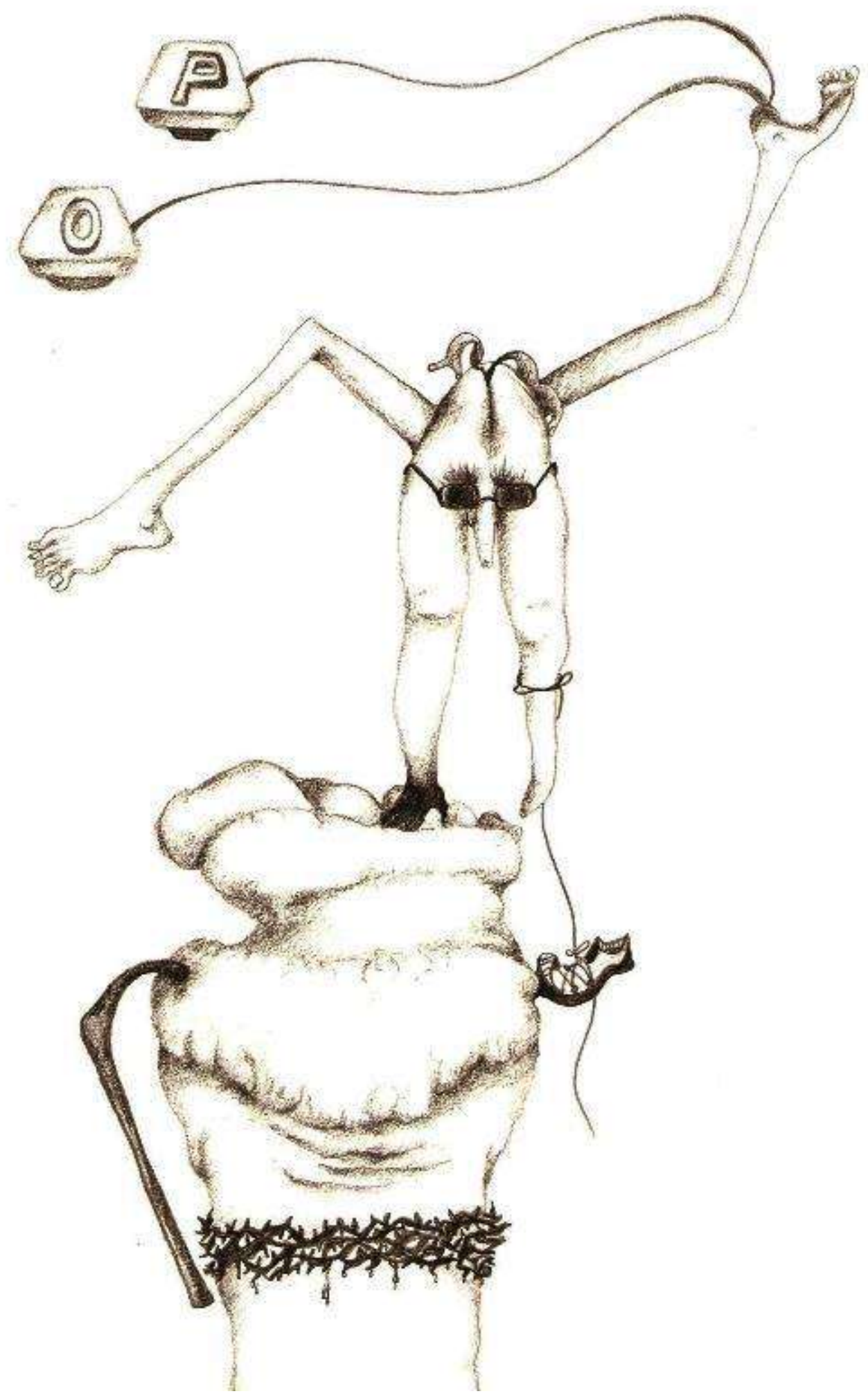

Pé do Pedro, 2012. Lápis sobre papel. 


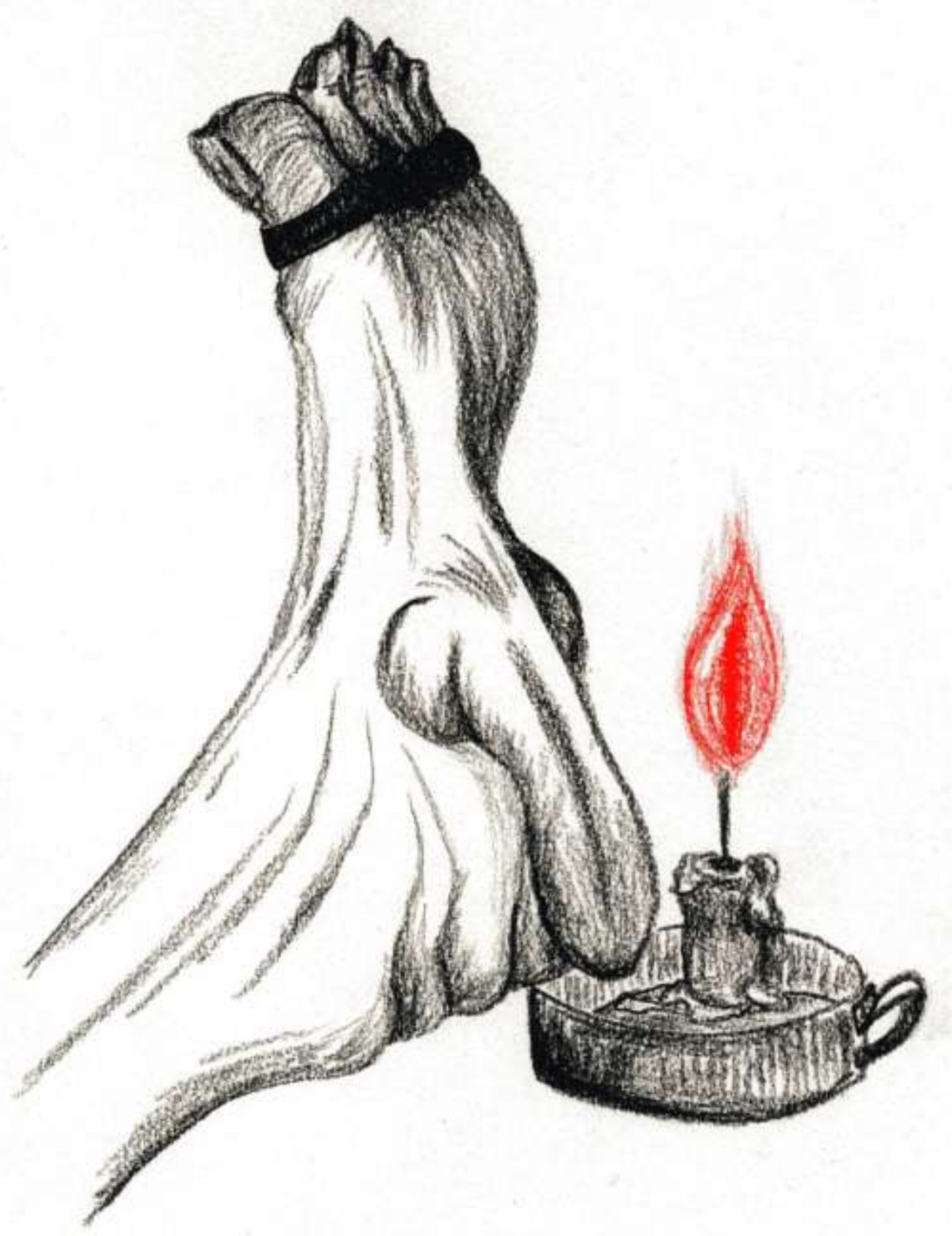

Sebo, 2014. Lápis carvão e pastel sobre papel. 


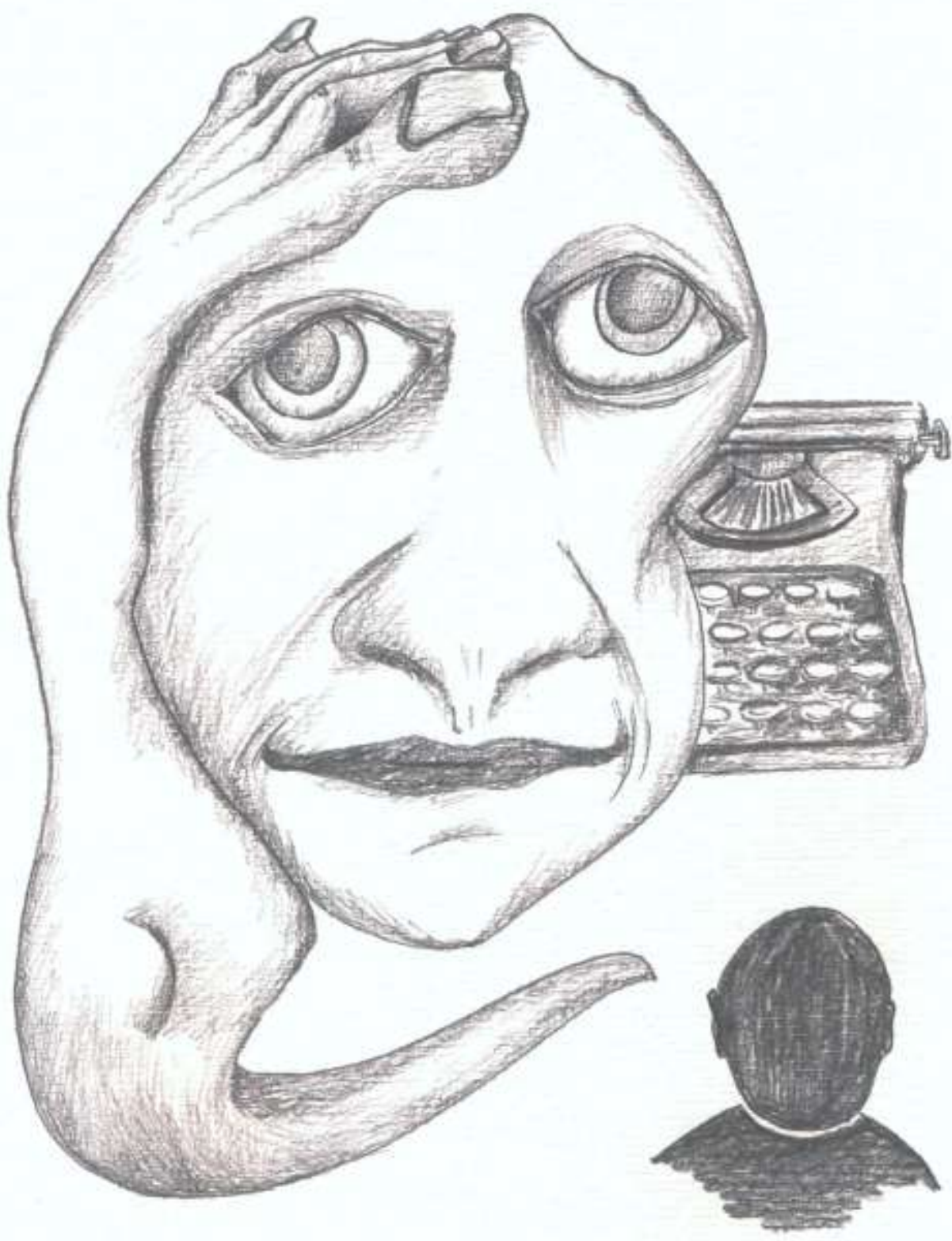

Limiar, 2016. Lápis sobre papel. 


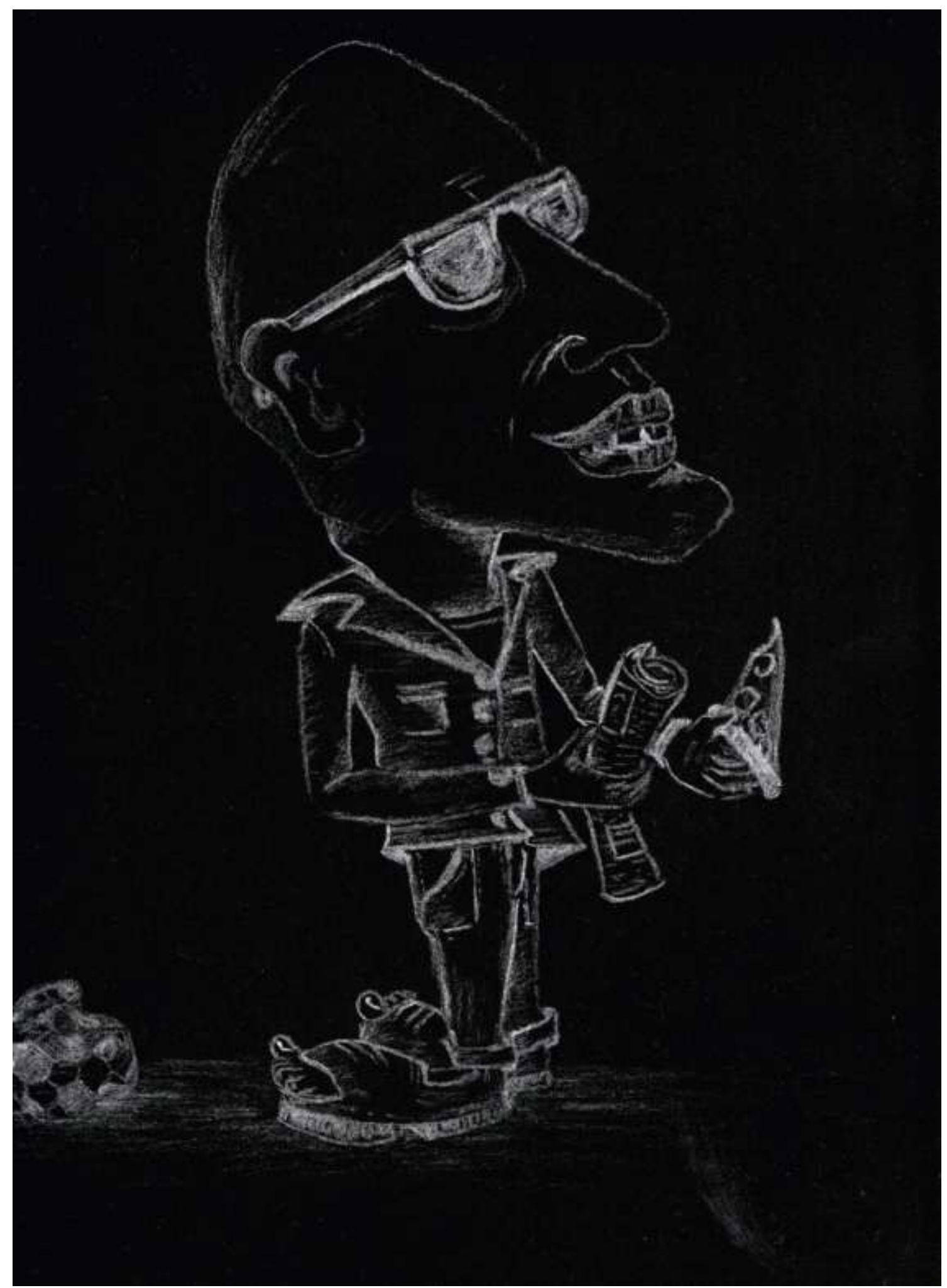

Raymundo Curupyra, 2014. Pastel branco sobre papel. 


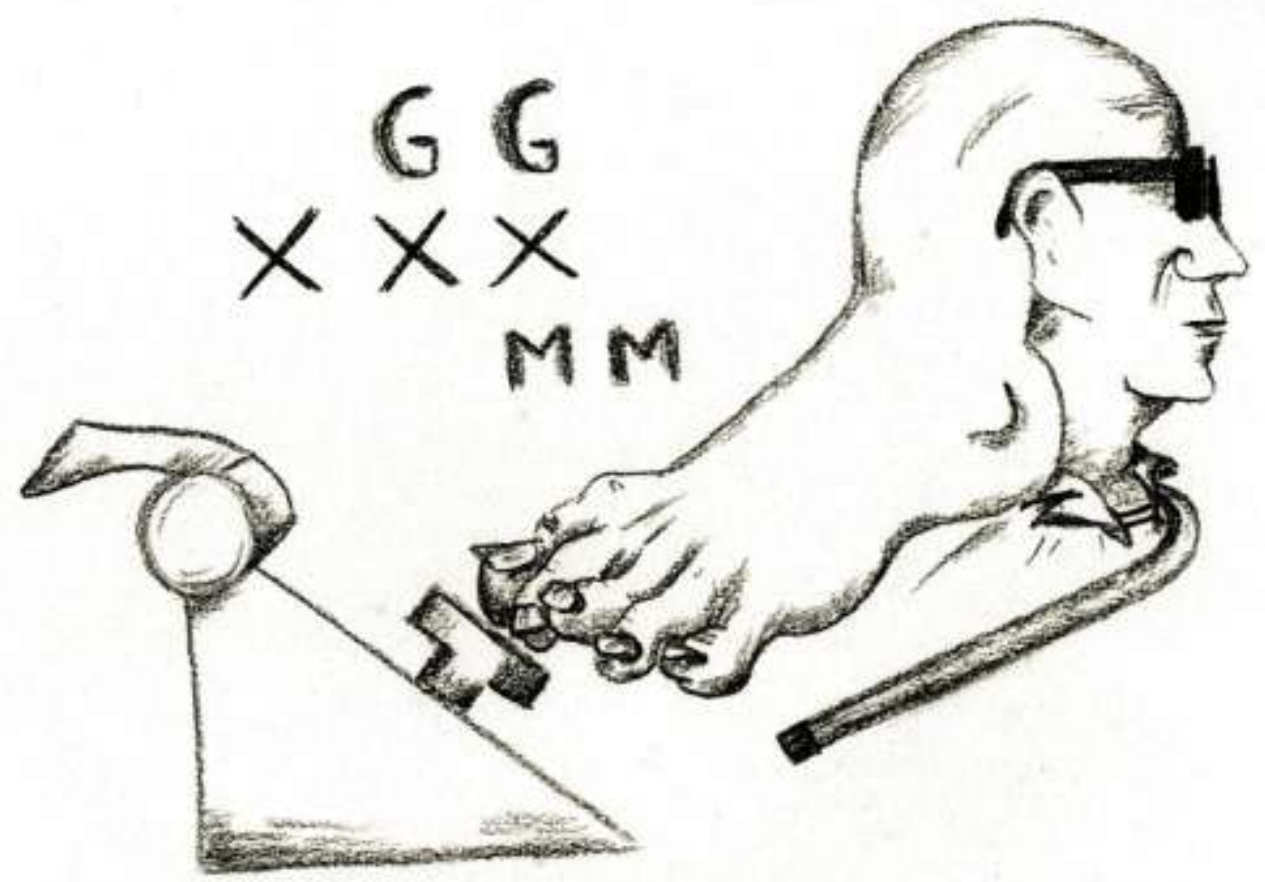

Máquina de escrever, 2014. Carvão sobre papel. 
- De Glauco Mattoso:

MATTOSO, Glauco. A maldição do Mago Marginal. São Paulo: Demônio Negro, 2007.

Animalesca escolha. Porto Alegre: AMEOP - ame o poema editora, 2004.

A planta da donzela. Rio de Janeiro: Lamparina editora, 2005.

e MARCATTI. As aventuras de Glaucomix, o pedólatra. São Paulo:

Ed. Expressão, 1990.

. As mil e uma línguas. São Paulo: Annablume, 2008.

. A aranha punk. São Paulo: Annablume, 2007.

(org.) e PIETROFORTE, Antonio Vicente Seraphim (org.). M(ai)s -

Antologia SadoMasoquista da Literatura Brasileira. São Paulo: Annablume, 2008.

(org.) e PIETROFORTE, Antonio Vicente Seraphim (org.). Aos pés das letras - Antologia podólatra da literatura brasileira. São Paulo: Annablume (Selo [e] Editorial), 2010.

. Calo à bocca. São Paulo: Lumme editor, 2010.

. Cara e coroa, cainho e carão. Paraná: Travessa dos editores, 2004.

. Cautos Causos - Contos lyricos. São Paulo: Lumme Editor, 2012.

. Centopéia: Sonetos nojentos \& quejandos. São Paulo: Edições Ciência do acidente, 1999.

. Cinco Ciclos e meio século. São Paulo Annablume, 2009.

. Contos hediondos. São Paulo: Annablume editora, 2008.

- Dicionarinho do palavrão \& correlatos (Português-Inglês/Inglês-

Português). 4" Ed. Rio de Janeiro: Record, 2005. 
. Faca cega - E outras pelejas sujas. São Paulo: Annablume, 2007.

. Galería alegría: Poemas de Glauco Mattoso. São Paulo: Memorial, 2002.

. Geléia de rococó: sonetos barrocos. São Paulo: Edições Ciência do acidente, 1999.

. Jornal Dobrabil. 2ª Ed. (fac-similar) São Paulo: lluminuras, 2001.

. Línguas na Papa: Uma sala dos mais insípidos aos mais picantes. São Paulo: Pindaíba, 1982.

. Malcriados, recriados: sonetário sanitário. São Paulo: Annablume, 2009.

. Manual do podólatra amador: aventuras \& leituras de um tarado por pés. São Paulo: All Books, 2006.

. Manual do pedólatra amador. São Paulo: Editora Expressão, 1986.

.MACIEL, Nilto. Queda de braço: uma antologia do conto marginal. Rio de Janeiro: Club dos Amigos do Marsaninho, 1977.

- O calvário dos carecas - História do trote estudantil. São Paulo: EMW Editores, 1985.

. O Cancioneiro carioca e brasileiro. São Paulo: Annablume, 2008.

- O poeta da crueldade. (Série Mattosiana, v.8). São Paulo: Annablume (Selo Demônio Negro), 2011.

. O poeta pecaminoso. São Paulo: Lumme Editor, 2011a.

. "O poeta põe, a crítica tica" in MASSI, Augusto (org). Artes e ofícios da poesia. Porto Alegre: Artes e ofícios, 1991.

. O que é poesia marginal. São Paulo: Editora Brasiliense, 1981.

. O que é tortura. São Paulo: Nova Cultural/Brasiliense, 1986.

.O poeta põe, a crítica tica”. In MASSI, Augusto (org.) Artes e ofícios da poesia. Porto Alegre: Artes e ofícios, 1991. . Panacéia - Sonetos colaterais. São Paulo: Nankin Editorial, 2000. 
. Paulisséia Ilhada - Sonetos tópicos. São Paulo: Edições Ciência do Acidente, 1999.

. Pegadas noturnas. Rio de Janeiro: Lamparina editora, 2004.

- Poemida e sonetrilha. (Série Mattosiana, v.10). São Paulo:

Annablume (Selo Demônio Negro), 2011b.

. Poesia digesta (1974/2004). São Paulo: Landy Editora, 2004.

. Poética na política. São Paulo: Geração Editorial, 2004.

. Poesia vaginal. São Paulo: Hedra, 2015.

. Raymundo Curupyra, o caypora. São Paulo: Tordesilhas, 2012.

. Revista Dedo Mingo - Jornal Dobrabil. (Sem indicativo de cidade, editora e ano de publicação).

. Saccola de feira. São Paulo: nVersos, 2014.

. Skinhead: Letra por letra. São Paulo, Rotten Books, 1995.

. Sonetos de Pessoa. São Paulo: Lumme Editor, 2013.

Sonetos de Moraes. São Paulo: Lumme Editor, 2015.

. Tripé do tripúdio e outros contos hediondos. São Paulo: Tordesilhas, $2011 b$.

SILVA, Pedro José Ferreira da. Memórias de um pueteiro: as melhores gozações de Glauoc Mattoso. Rio de Janeiro: Edições Trote, 1982.

\section{- Sobre Glauco Mattoso:}

ALVES, Franklin. "Esse elogio da sombra: Poesia e cegueira em Glauco Mattoso". In. Zunái - Revista de poesia \& debates. 2002. Disponível em < http://www.revistazunai.com/ensaios/elogio_sombra_poesia_glauco_mattoso.ht $\mathrm{m}>$ acesso em março de 2012. 
BARBOSA, Daniela Maria. Jornal Dobrabil: a irreverência poética de Glauco Mattoso. Brasília: Dissertação (Mestrado em Literatura) - Universidade de Brasília (UnB), 2007.

BUENO, Alexei. Antologia pornográfica: de Gregório de Mattos a Glauco Mattoso. Rio de Janeiro: Nova Fronteira, 2004.

BUTTERMAN, Steven F. Perversions on parade - Brazilian Literature of Transgression and Postmodern Anti-Aesthetics in Glauco Mattoso. San Dieo: Hyperbole Books, 2005.

CAIXETA, Ana Paula A.. A "estética do pé sujo": Estudo da obra Manual do podólatra amador, de Glauco Mattoso. Brasília: Dissertação (Mestrado em Literatura) - Universidade de Brasília, 2013.

. CAIXETA, Ana Paula A.. RICHARD, Rosimara A.. Conversando com Glauco Maattoso: O processo criativo do escritor maldito. Revista UniLetras, 2014. Disponível em: <http://www.revistas2.uepg.br/index.php/uniletras/article/viewFile/6733/4749> . Acesso em janeiro de 2016.

FOSTER, David William. "À guisa de apresentação". In: MATTOSO, Glauco. Manual do podólatra Amador (2 $\left.{ }^{\mathrm{a}} \mathrm{Ed}\right)$. São Paulo: All Books, 2006.

LISBOA, Emmanuel Gonçalves G. Deus e o Diabo na Alcova: uma leitura do sonetário de Glauco Mattoso em busca das presenças poéticas de Deus e do Diabo. São Paulo: Dissertação (Mestrado em Ciências da Religião). PUC-SP, 2010.

MONTEIRO, Winnie Wouters. Os sonetos na obra de Glauco Mattoso. Disponível em <http://www.uel.br/pos/letras/EL/vagao/EL9Art3.pdf> acesso em setembro de 2012.

NASCIMENTO, Rosimere Meireles. Glauco Mattoso: um marginal erudito. Vitória: Dissertação (Mestrado em Estudos Literários). Universidade Federal do Espírito Santo, 2002.

OLIVERIA, Solange Ribeiro de. A literatura $e$ as artes, hoje: o texto coprofágico. 
(UFMG/UFOP).<http://www.pgletras.uerj.br/matraga/matraga21/arqs/matraga21 a05.pdf $>$ Acesso em maio de 2015.

PERLONGHER, Néstor. In MATOSO, Glauco. Manual do pedólatra amador. São Paulo: Editora Expressão, 1986.

RIBEIRO, Leo Gilson. "Prefácio” In MATTOSO, Glauco. Manual do pedólatra amador. São Paulo: Editora Expressão, 1986.

SILVA, Maria Aparecida L. H. da. O des-curso Cínico: A poética de Glauco Mattoso. Santa Catarina: Tese (Doutorado em Teoria Literária) Universidade Federal de Santa Catarina, 2009.

SILVA, Susana Souto. O caleidoscópio Glauco Mattoso. Alagoas: Tese (Doutorado em Letras e Linguística) Universidade Federal de Alagoas, 2008.

- Crítica literária e heteronímia: Glauco Mattoso e Pedro Ulysses Campos. Olho d'água, São José do Rio preto, pp. 116-125.

SOUSA, Rafaella Lemos dos Reis. Glauco Mattoso: escrita e transgressão. Rio de Janeiro: Dissertação (Mestrado em Letras) - Universidade do Estado do Rio de Janeiro, 2010.

TELLES, Sérgio. "Nota do organizador da coleção". In MATTOSO, Glauco. Manual do Podólatra Amador: aventuras \& leituras de um tarado por pés. São Paulo: All Books, 2006.

- Glauco Mattoso - artigos e entrevistas:

MATTOSO, Glauco. Ephemerdas - Blocos Online. Disponível em < http://www.blocosonline.com.br/literatura/prosa/colunistas/glauco/gm14emdiant e/onomastindex.php > Acesso em agosto de 2015.

Acesso em outubro de 2014.

. Disponível em < www.youtube.com/user/Gatinhocachorro> Acesso em novembro de 2014. 
. Disponível em <http://www.cronopios.com.br> Acesso em junho de 2015.

. Disponível em < http://enochhaym.blogspot.com.br/2008/07/glaucomattoso-i.html?zx=8579877ae5dd4dec> Acesso em novembro de 2014.

. Disponível em < http://novo.itaucultural.org.br/?s=glauco+mattoso> Acesso em setembro de 2014.

. [Entrevista a Caio Gagliardi]. Crítica \& Companhia, 2005. Disponível em <http://glaucomattoso.sites.uol.com.br/caio.htm> acesso em maio de 2015. . http://www.roteirosonline.com.br/comentariosglauco.htm> acesso em junho de 2015.

. Glauco Mattoso Apresenta: Cricriação e Crititica: zelos e mazelas na balança do ofício poético. Disponível em $<$ http://www.elsonfroes.com.br/croncal.htm>; acesso em julho de 2014.

- Germina: Revista de Literatura e Arte.
http://www.germinaliteratura.com.br/gm.htm $>$ Acesso em abril de 2015. - Entrevista concedida ao Memorial (org./SP). Disponível em http://www.memorial.org.br/cbeal/poetas-na-bilbioteca/glaucomattoso/entrevista-mattoso/> Acesso em maio de 2015. - Entrevista: O chulo e o chic em depoimento do poeta Glauco Mattoso. Cult - Revista Brasileira de Literatura, № 39. São Paulo, 2002.

\section{- Filme sobre Glauco Mattoso:}

VINAGRE, Gustavo. Filme para poeta cego - Documentário sobre o poeta Glauco Mattoso. Disponível em < https://www.youtube.com/watch?v=s2QM5DwzXDo> 


\section{- Bibliografia geral:}

ADORNO, Theodor. Indústria cultural e sociedade. (Trad. Juba Elisabeth Levy). Rio de Janeiro: Paz e Terra, 2002.

AGAMBEN, Giorgio. O que é o contemporâneo? E outros ensaios. (Trad. Vinícius Nicastro Honesko). Chapecó/SC; Argos, 2009.

ALENCAR, José de. A pata da gazela. São Paulo: Ática, 1984.

ANDRADE, Oswald de. Revista de Antropofagia - $1^{a}$ e $2^{a}$ dentições (19281929). Edição fac-similar. São Paulo, Círculo do Livro, Abril S/A Cultural e Industrial, 1975.

ANTUNES, Arnaldo. Nome (1993) Nome. São Paulo: BMG Ariola, 1993. (disco compacto (44 min): digital, estéreo. M30.072).

ARISTÓTELES. Poética. (Trad. Baby Abrão) São Paulo: Editora Nova Cultura, 1999.

AUERBAHC, Erich. Mimesis: a representação da realidade na literatura ocidental. (Vários tradutores). São Paulo: Perspectiva, 2011.

BAKHTIN, Mikhail. Estética da criação verbal. (Trad. Paulo Bezerra) São Paulo: Martins Fontes, 2003.

. Cultura Popular na Idade Média e no Renascimento: o contexto de

François Rabelais. (Trad. Yara Frateschi Vieira). São Paulo: Hucitec; Brasília: Editora Universidade de Brasília, 2008.

. Questões de literatura e de estética: a teoria do romance. (Trad.

Aurora

Fornoni Bernardini et all). São Paulo:

Hucitec, 1988.

Marxismo e filosofia da linguagem. (Trad. Michel Lahud e Yara

Frateschi Vieira, com colaboração de Lúcia Teixeira Wisnik e Carlos Henrique D. Chagas Cruz). São Paulo: Hucitec, 2014.

BARROSO, Wilton. Elementos para uma Epistemologia do Romance. In Colóquio: Filosofia e literatura, 2003, São Leopoldo. Usininos. 
. Os sonâmbulos de Broch e a metamorfose do romance - Corpos e Intrusões: legitimação. Disponível em:

<https://drive.google.com/file/d/0B3rYBdlpwpzbeC1CMWJXZ3dteW8/view?pref $=2 \&$ pli $=1>$ Acesso em abril de 2016.

BARROSO, Maria Veralice. A obra romanesca de Milan Kundera: um projeto estético conduzido pela ação de Don Juan. Tese (Doutorado em Literatura) Universidade de Brasília. Brasília, 2013.

BARTHES, Roland. "A morte do autor". In: O rumor da língua. $2^{\underline{a}}$ ed. São Paulo: Martins Fontes, 2004.

BATAILLE, Georges. A literatura e o mal. (Trad. Suely Bastos). Porto Alegre: L\&PM, 1989.

. O erotismo. (Trad. Fernando Scheibe). Belo Horizonte: Autêntica Editora, 2013.

BENJAMIN, Walter. Magia e técnica, arte e política: ensaios sobre literatura e história da cultura. (Trad. Sérgio Paulo Rouanet). São Paulo: Brasiliense, 1994.

BERGSON, Henri. Matéria e memória - Ensaio sobre a relação do corpo com o espírito. (Trad. Paulo Neves da Silva) São Paulo: Martins Fontes, 1990.

. O riso - Ensaio sobre a significação da comicidade. (Trad. Ivone

Castilho Benedetti) São Paulo: Martins Fontes, 2007.

BETEGA, Lidiana da Silva. O Pasquim e os anos de chumbo. Santa Maria: Monografia (Graduação em Jornalismo) - Centro Universitário Franciscano, 2012.

BOCAGE, Manuel Maria Barbosa Du. Poesias eróticas, burlescas e satíricas. Rio de Janeiro: Lacerda Ed., 1999.

BRAS, Gérard. Hegel e a Arte - Uma apresentação da Estética. (Trad. Maria Luiza X. de A. Borge) Rio de Janeiro: Jorge Zahar Editor, 1990.

Brasil: nunca mais. Rio de Janeiro: Arquidiocese de São Paulo: Editora Vozes, 1985.

BROCH, Hermann. Quelques Remarques à propôs du kitsch. Paris: Éditions Allia, 2012. 
- Espírito e espírito de época: ensaios sobre a cultura da modernidade. (Trad. Marcelo Backes; Trad. Posfácio Claudia Abeling). São Paulo: Benvirá, 2014.

BUENO, Márcio. "A imprensa alternativa". In MELLO, Maria Amélia (org). 20 anos de resistência: alternativas da cultura no regime militar. Rio de Janeiro: Espaço e tempo, 1986.

CAC, Paco. Revistas Literárias Brasileiras (1970/2005). Brasília: Stephanie Gráfica e Editora Ltda, 2006.

Revistas Literárias Brasileiras - século XX. Brasília: Edição do autor, 2012

CALIRMAN, Claudia. Arte brasileira na ditadura militar: Antonio Manuel, Artur Barrio e Cildo Meireles. (Trad. Dmitry Gomes, Vitor Heringer). Rio de Janeiro: Reptil, 2013.

CAMPOS, Haroldo de. Metalinguagem \& outras metas: ensaios de teoria e crítica literária. São Paulo: Perspectiva, 2013.

CAMPOS, Haroldo de. PIGNATARI, Décio. Teoria da poesia concreta: textos críticos e manifestos 1950-1960. Cotia, SP: Ateliê Editorial, 2006.

CHARLIE HEBDO - Journal Irresponsable. Disponível em <http://charliehebdo.fr/> Acesso em maio de 2015.

CHILVERS, Ian (ed.). Dicionário Oxford de arte. (Trad. Marcelo Brandão Cipolla). São Paulo: Martins Fontes, 2007.

COELHO, Teixeira. Moderno pós moderno: modos \& versões. São Paulo: lluminuras, 2005.

COMPAGNON, Antoine. O demônio da teoria: literatura e senso comum. (Trad. Cleonice Paes Barreto Mourão e Consuelo Fortes Santiago). Belo Horizonte: Editora UFMG, 2010.

COLONNA, Vincent. Autofiction \& autres mythomanies littéraires. MidiPyrénées: Éditions Tristram, 2004. 
DELEUZE, Gilles. Sacher-Masoch: o frio e o cruel. (Trad. Jorge Bastos) Rio de Janeiro: Jorge Zahar Editora, 2009.

DELIGNE, Alain. "De que maneira o riso pode ser considerado subversivo?" (Trad. Maria Elizabeth Chaves de Mello). In LUSTOSA, Isabel (org). Imprensa, humor e caricatura: a questão dos estereótipos culturais. Belo Horizonte: Ed. UFMG, 2011.

DIAS, Maria Ângela. GLENADEL, Paula (organizadoras). Valores do abjeto. Niterói: Ed. Universidade Federal Fluminense, 2008.

DOUBROVSKY, Serge. Fils. Paris: Folio/Éditions Galilée, 1977.

EAGLETON, Terry. Teoria da literatura: uma introdução. (Trad. Waltensir Dutra) São Paulo: Martins Fontes, 2006.

ECO, Umberto. Apocalípticos e integrados. Editora Perspectiva: São Paulo, 1976.

. Seis passeios pelos bosques da ficção. (Trad. Hildegard Feist). São Paulo: Companhia das Litras, 1994.

FERNANDES, Ronaldo Costa. O narrador do romance: e outras considerações sobre o romance. Rio de Janeiro: Sette Letras, 1996.

FIGUEIREDO, Eurídice. Mulheres no espelho: autobiografia, ficção, autoficção. Rio de Janeiro: EdUERJ, 2013.

FOUCAULT, Michel. História da sexualidade 1 - A vontade de saber. (Trad. Maria Thereza da Costa Albuquerque e José Augusto Guilhon Albuquerque). São Paulo: Edições Graal, 2011.

. Arqueologia do saber. (Trad. Luiz Felipe Baeta Neves). Rio de Janeiro: Forense Universitária, 1987.

. A ordem do discurso. (Trad. Laura Fraga de Almeida Sampaio). São Paulo: Edições Loyola, 2012.

. Estética: literatura e pintura, música e cinema. (Trad. Inês Autran Dourado Barbosa). Rio de Janeiro: Forense Universitária, 2013.

. Ética, sexualidade, política. (Trad. Elisa Monteiro, Inês Autran Dourado Barbosa). Rio de Janeiro: Forense Universitária, 2010. 
Microfísica do poder. (Trad. Roberto Machado). Rio de Janeiro: Paz e Terra, 2015.

FUKS, Julián. Histórias de literatura e cegueira. Rio de Janeiro: Reccord, 2007. GADAMER, H. G. Verdade e Método 1. (Trad. Flávio Paulo Meurer) Rio de Janeiro: Vozes, 1997.

GALLE, Helmut. Elementos para uma nova abordagem da escritura autobiográfica. In Matraga. PPG-Letras/UERJ: 2006.

GENETTE, Gerard. Palimpsestos: a literatura de segunda mão. (Trad. Luciene Guimarães e Maria Antônia Ramos Coutinho). Belo Horizonte/Faculdade de Letras, 2006.

GOODWIN, Ricky. "A monovisão dos estereótipos no desenho de humor contemporâneo". In LUSTOSA, Isabel (org). Imprensa, humor e caricatura: a questão dos estereótipos culturais. Belo Horizonte: Ed. UFMG, 2011.

GREEN, James N. e QUINALHA, Renan. Ditadura e homossexualidades: repressão, resistência e a busca da verdade. São Carlos: EdUFSCAR, 2014.

GRUDA, M. P. P. "O controverso discurso do politicamente correto: algumas considerações e desdobramentos". In Revista Brasileira de Psicologia, 1(2), 2014.

HEGEL, Georg Wilhelm Friedrich. Cursos de Estética I. (Trad. de Marco Aurélio Werle - $2^{\underline{a}}$ ed) São Paulo: Editora Universidade de São Paulo, 2001.

. Curso de estética: O belo na arte. (Trad. Álvaro Ribeiro e Orlando Vitorino). São Paulo: Editora WMF Martins Fontes, 2009.

HOUAISS, Antônio. Enciclopédia e dicionário. Rio de Janeiro: Edições Delta, 1997.

HUTCHEON, Linda. Poética do pós-modernismo: história, teoria, ficção. (Trad. Ricardo Cruz) Rio de Janeiro: Imago Ed., 1991.

INWOOD, Michael. Dicionário Hegel (Trad. Álvaro Cabral). Rio de Janeiro: Jorge Zahar Ed., 1997.

ISER, Wolfgang. O ato da leitura: uma teoria do efeito estético. Tradução: Johannes 
Kretschmer. São Paulo: Ed. 34, 1996.

. O Fictício e o Imaginário: Perspectivas de uma antropologia literária. (Trad. Johannes Kretschmer). Rio de Janeiro: EdUERJ, 2013.

JAPIASSÚ, Hilton, MARCONDES, Danilo. Dicionário básico de filosofia. Rio de Janeiro: Jorge Zahar Ed., 1996.

JAUSS, Hans Robert. "O prazer estético e as Experiências Fundamentais da Poiesis, Aesthesis e Katharsis". In: LIMA, Luiz Costa (org.). A literatura e o leitor - textos de Estética da Recepção. Rio de Janeiro: Paz e Terra, 1979.

KANT, Immanuel. Crítica da faculdade de juízo. (Trad. Valério Rohden e António Marques) Rio de Janeiro: Forense Universitária, 2010.

. Crítica da razão pura. (Trad. Fernando Costa Mattos). Petrópoles, RJ: Vozes; Ed. Universitária São Francisco, 2015.

KLAXON - Mensário de Arte Moderna. Edição fac-similar. São Paulo, Livraria Martins Editora, 1976.

KLINGER, Diana. Escritas de si, escritas do outro: o retorno do autor e a virada etnográfica. Rio de Janeiro: 7Letras, 2012.

KOCH, Ingedore G. Villaça; BENTES, Anna Christina; CAVALCANTE, Mônica Magalhães. Intertextualidade - Diálogos Possíveis. São Paulo: Cortez, 2008.

KRISTEVA, Julia. Introdução à semanálise. (Trad. Lúcia Helena França Ferraz) São Paulo: Editora Perspectiva, 1974.

Pouvoirs de l'horreur: Essai sur l'abjection. Seuil-France: Éditions du Seuil, 1980.

KUCINSKI, Bernardo. O fim da ditadura militar. São Paulo: Contexto, 2001.

KUSHNIR, Beatriz. "A grande imprensa apoiou o golpe e a ditadura" In Carta Capital: 50 anos do golpe, 2014. Disponível em <http://www.cartacapital.com.br/politica/a-grande-impressa-apoiou-o-golpe-e-aditadura-e-nao-teve-papel-relevante-para-o-fim-do-regime-1979.html> Acesso em maio de 2015.

KUNDERA, Milan. A arte do romance. (Trad. Teresa Bulhões) São Paulo: Companhia das Letras, 2009. 
. A insustentável leveza do ser. (Trad. Teresa Bulhões) São Paulo: Companhia das Letras, 2008.

A cortina: ensaio em sete partes. (Trad. Teresa Bulhões) São Paulo: Companhia das Letras, 2006.

LALANDE, André. Vocabulário técnico e crítico da filosofia. (Trad. Fátima Sá Correia). São Paulo: Martins Fontes, 1993.

LEJEUNE, Philippe. O pacto autobiográfico: de Rousseau à Internet. Org. Jovita M.G. Noronha. (Trad. Jovita M.G. Noronha e Maria Inês C. Guedes) Belo Horizonte: UFMG, 2008.

LEMOS, Andréa. A Editora Brasiliense e a oposição à ditadura civil-militar brasileira. Revista Crítica Histórica, v. 10, p. 178, 2014.

LIMA, Luiz Costa. História, Ficção, Literatura. São Paulo: Companhia das Letras, 2006.

LIMA, Rogério da Silva. O dado e o óbvio: o sentido do romance na pósmodernidade. Brasília: EDU/Universa, 1998.

LIPOVETSKY, Gilles. SERROY, Jean. A estetização do mundo: viver na era do capitalismo artista. (Trad. Eduardo Brandão). São Paulo: Companhia das Letras: 2015.

LUSTOSA, Isabel (org). Imprensa, humor e caricatura: a questão dos estereótipos culturais. Belo Horizonte: Ed. UFMG, 2011.

MAFFESOLI, Michel. Elogio da razão sensível. (Trad. Albert Christophe e Migueis Stuckenbruk). Petrópolis, RJ: Vozes, 2008.

A parte do diabo: resumo da subversão pós-moderna. (Trad. Clóvis Marques). Rio de Janeiro: Record, 2004.

. Homo eroticus: comunhões emocionais. (Trad. Abner Chiquieri). Rio de Janeiro: Forense, 2014.

MARTINS, Raimundo. "Sobre enredos e imagens do corpo". In MEDEIROS, Afonso. O imaginário do corpo: entre o erótico e o obsceno: fronteiras líquidas da pornografia. Goiânia: FUNAPE, 2008.

MATOS, Gregório de. Poemas satíricos. São Paulo: Martin Claret, 2002. 
MELLO, Maria Amélia (org). 20 anos de resistência: alternativas da cultura no regime militar. Rio de Janeiro: Espaço e tempo, 1986.

MíCCOLIS, Leila. "Literatura Inde(x)pendente" In MELLO, Maria Amélia (org). 20 anos de resistência: alternativas da cultura no regime militar. Rio de Janeiro: Espaço e tempo, 1986.

MINOIS, George. História do riso e do escárnio. (Trad. Maria Elena Ortiz Assumpção) São Paulo: Editora UNESP, 2003.

MOISÉS, Massaud. A análise literária. São Paulo: Editora Pensamento-Cultrix Ltda, 2005.

. Dicionário de termos literários. São Paulo: Cultrix, 2013.

MOLES, Abraham. O kitsch: a arte da felicidade. (Trad. Sérgio Miceli). São Paulo: Perspectiva, Ed. Da Universidade de São Paulo, 1972.

MOREIRA, Sônia Virgínia. "As alternativas da cultura (anos 60/70)". In MELLO, Maria Amélia (org). 20 anos de resistência: alternativas da cultura no regime militar. Rio de Janeiro: Espaço e tempo, 1986.

MINOIS, George. História do riso e do escárnio. (Trad. Maria Elena Ortiz Assumpção) São Paulo: Editora UNESP, 2003.

NIETZSCHE, Friedrich Wilhelm. A gaia ciência. (Trad. Paulo César de Souza). São Paulo: Companhia das Letras, 2012.

NORONHA, Jovita Maria Gerheim. Ensaios sobre a autoficção. Belo Horizonte: Editora UFMG, 2014.

OLIVEIRA, Luciano. Do nunca mais ao eterno retorno: uma reflexão sobre a tortura. São Paulo: Brasiliense, 1994.

OSTROWER, Fayga. Criatividade e processos de criação. Petrópolis: Vozes, 1987.

PAULINO, Itamar Rodrigues. Um olhar sobre a degradação dos valores humanos a partir da obra "Os sonâmbulos", de Hermann Broch. Tese (Doutorado em Filosofia), Universidade de Brasília, Brasília: 2006.

PERRONE-MOISÉS, Leyla. Fernando Pessoa, aquém do eu, além do outro. São Paulo: Martins Fontes, 2001. 
PESSOA, Fernando. Teoria da heteronímia. Porto: Assírio \& Alvim, 2012. - Livro do desassossego: composto por Bernardo Soares, ajudante de guarda-livros na cidade de Lisboa. São Paulo: Companhia das Letras, 2006.

REIS, Daniel Aarão. Ditadura militar, esquerdas e sociedade. Rio de Janeiro: Jorge Zahar Ed., 2000.

RICHTER, Hans. Dada: arte e antiarte. Tradução Marion Fleischer. São Paulo: Martins Fontes, 1993.

Dada 1916-1966 -Documentos do movimento Dada Internacional. Tradução Betty M. Kunz. Catálogo (1916-1966).

ROUDINESCO, Elisabeth; PLON, Michel. Dicionário de psicanálise. (Trad. Vera Ribeiro, Lucy Magalhães) Rio de Janeiro: Jorge Zahar Ed., 1998)

SACHER-MASOCH, Leopold von. A vênus das peles. (Trad. Saulo Krieger) São Paulo: Hedra, 2008.

SAMOYAULT, Tiphaine. A intertextualidade. (Trad. Sandra Nitrini). São Paulo: Aderaldo \& Rothschild, 2008.

SANT'ANNA. Affonso Romano de. Paródia, paráfrase \& Cia. São Paulo: Editora Ática, 2003.

SADE, Marquês de. Os 120 dias de Sodoma ou A escola da libertinagem. (Trad. Alain François) São Paulo: lluminuras, 2008.

SCHOPENHAUER, A. Metafísica do belo. (Trad. Jair Barboza). São Paulo: Editora Unesp, 2003.

SILVA JR, A. R. Morte e decomposição biográfica em Memórias póstúmas de Brás Cubas. 219 f. Tese (Doutorado em Literatura Comparada). Universidade Federal Fluminense, Niterói, 2008.

SUASSUNA, Ariano. Iniciação à estética. $10^{\mathrm{a}}$ ed. - Rio de Janeiro: José Olympio, 2009.

TAVARES, Hênio. Teoria Literária. Belo Horizonte: Itatiaia, 2002.

TZARA, Trista. Os Sete Manifestos Dada. (Trad. José Miranda Justo). Hiena Editora: Lisboa, 1987. 
VAIHINGER, Hans. A filosofia do como se: sistema de ficções teóricas, práticas e religiosas da humanidade, na base de um positivismo idealista. (Trad. Johannes Kretschmer). Chapecó: Argos, 2011.

W.J.SOLHA, W.J. Capa In MATTOSO, Glauco. Cautos Causos - Contos lyricos. São Paulo: Lumme Editor, 2012.

ŽlŽEK, Slavoj. A visão em paralaxe. (Trad. Maria Beatriz de Medina). São Paulo: Boitempo, 2008. 